VICTOR NÓBREGA LUCCAS

\title{
MAPA ARGUMENTATIVO DO CASO ARAGUAIA EM PROTOCOLO DE DISPUTAS
}

ORIENTADOR: PROFESSOR DOUTOR GUILHERME ASSIS DE ALMEIDA

Dissertação de Mestrado

Faculdade de Direito da Universidade de São Paulo

São Paulo - 2013 


\title{
MAPA ARGUMENTATIVO DO CASO ARAGUAIA EM PROTOCOLO DE DISPUTAS
}

\author{
Dissertação de Mestrado apresentada como \\ requisito parcial para obtenção do título de \\ Mestre pela Faculdade de Direito da \\ Universidade de São Paulo. \\ Aluno: Victor Nóbrega Luccas \\ Orientador: Professor Doutor Guilherme Assis de \\ Almeida \\ $\mathrm{N}^{\mathrm{o}}$ USP: 5440546
}

Faculdade de Direito da Universidade de São Paulo São Paulo - 2013 
"O erro é conceber o homem como constituído de faculdades completamente separadas. O impasse é tirar da ação fundada na escolha qualquer justificação racional e, com isso, tornar absurdo o exercício da liberdade humana. Apenas a argumentação, da qual a deliberação constitui um caso particular, permite compreender nossas decisões."

PERELMAN, Chaïm e OLBRECHTS-TYTECA, Lucie. Tratado da Argumentação: A Nova Retórica (1958). $2^{\mathrm{a}}$ Ed.São Paulo: Martins Fontes, 2005, p. $52 / 53$. 
BANCA EXAMINADORA: 
À minha mãe, à minha avó

Lily e à minha avó Isabel (in memoriam). 


\section{AGRADECIMENTOS}

Antes de escrever estas linhas li como e a quem outras pessoas agradeceram. É importante consultar a jurisprudência. Afinal, os agradecimentos também são parte do trabalho e também tem que ser feitos da melhor maneira possível. Das minhas pesquisas extraí duas observações costumeiras que se aplicam perfeitamente ao meu caso. (i) Muitas pessoas contribuíram para a minha formação e especificamente para este trabalho. Parte das eventuais qualidades desse trabalho é devida a elas. Todos os erros e defeitos são exclusivamente minha culpa. (ii) Peço desculpas antecipadas por eventuais injustiças nesses agradecimentos. Espero não esquecer ninguém, mas, infelizmente, isso pode acontecer. Dito isso, agradeço:

Ao professor Guilherme Assis de Almeida, por ter me acolhido como orientando, pela sugestão da ADPF 153 como caso prático para estudo e pelos diálogos dos últimos três anos.

Ao professor Juliano Souza de Albuquerque Maranhão, pela participação na banca de qualificação, pelas indicações de textos sobre argumentação e oportunidades de conversas sobre o tema. Ao professor Thomas F. Gordon, pela disposição e gentileza ao conversar sobre o software Carneades e a diagramação de argumentos. À senhora Elisa Andrade, minha revisora de português, pela presteza e paciência na leitura atenta desse trabalho.

Aos meus professores da época da graduação na DIREITO GV, pela contribuição na minha formação. Os textos e livros de alguns foram usados como referência ao longo deste trabalho. Mas o que me ensinaram está para além do direito material. Seus reflexos podem ser encontrados nesta dissertação e na atividade acadêmica e profissional que pude desenvolver até hoje.

Aos meus amigos da graduação da DIREITO GV, por todas as discussões jurídicas e nada jurídicas que travamos ao longo desses 8 anos: Daniel Tavela Luís (obrigado especialmente por emprestar a paz de Campos do Jordão para que eu pudesse escrever), Luís Antônio Gonçalves de Andrade, André Werebe, Juliana Villa Mello, 
Alexandre Pacheco da Silva e Marina Bozzola. Aos meus amigos desde os tempos do colegial, Bruno Bianco Silva de Melo e Marina Simões Pereira, pela amizade que já passa de uma década. A todos os mencionados e outros amigos, agradeço fortemente pela paciência com os sumiços por conta da dissertação.

À minha família, por toda compreensão e apoio. Ao meu avô Marconi, por compartilhar as suas memórias da época do regime militar. À minha irmã Bianca, por ter me deixado ocupar a sala com o computador, montes de livros, anotações e bagunças por tanto tempo sem nunca reclamar. Ao meu Tio Maurício, pela leitura de várias versões da parte histórica do trabalho.

Ao Sr. Hernan Chaimovich, pela disposição em ler o primeiro capítulo. Novamente ao Sr. Hernan e à Dona Iolanda Cuccovia, por terem cedido um computador e espaço em sua casa quando meu notebook resolveu que iria entrar em greve no final de semana.

À Mariana Chaimovich, pelas leituras de diversas versões de cada parte deste trabalho, pelo incentivo, pela paciência, pelo carinho, pela compreensão, pelos macarrões com molho de tomate, por tudo e mais um pouco. E, principalmente, por aquecer um porco-espinho. 


\section{RESUMO}

O presente trabalho tem duplo objetivo, prático e teórico. Em termos práticos, busca sistematizar as discussões sobre a responsabilização dos militares e do Estado por acontecimentos do regime militar, bem como sobre a busca da verdade e a preservação da memória. Destacam-se nas discussões os acontecimentos da Guerrilha do Araguaia. Em termos teóricos, tem a intenção de apresentar uma exposição compreensiva da Teoria da Argumentação, tentando adaptá-la, na medida do possível, às necessidades da Argumentação Jurídica. Para cumprir esse duplo objetivo, o trabalho aplica a Teoria da Argumentação às discussões sobre o regime militar almejando benefícios para a teoria e para a prática. Desse modo, o trabalho inicia apresentando os principais conceitos e ferramentas da Teoria da Argumentação. Em seguida, realiza algumas adaptações das ferramentas para que sejam utilizadas na argumentação jurídica. Por fim, utilizando os conceitos e ferramentas expostos e adaptados, apresenta o Mapa Argumentativo dos debates sobre o regime militar, com destaque para as discussões sobre a possibilidade de responsabilizar criminalmente os militares por torturas, execuções e desaparecimentos forçados. São levados em consideração especialmente os aspectos fáticos do caso da Guerrilha do Araguaia e argumentos levantados pelo STF no julgamento da ADPF 153 e pela Corte Interamericana de Direitos Humanos no Caso Gomes Lund ("Guerrilha do Araguaia”) v. Brasil. A dissertação conclui que os militares não foram beneficiados pela Lei de Anistia e aponta para a continuidade dos debates tanto sobre o aspecto criminal quanto outros problemas identificados no Mapa. Na parte teórica, chama-se atenção para a necessidade de continuar o estudo da Teoria da Argumentação e de adaptá-la às necessidades da Argumentação Jurídica.

Palavras-chave: Regime Militar, Araguaia, Anistia, Teoria da Argumentação, Argumentação Jurídica. 


\begin{abstract}
This dissertation has two objectives: a practical and a theoretical one. The practical objective is to organize discussions concerning the responsibility of the State and the Military due to events occurred in the Brazilian Military Government, as well as discussions about the search for the historical truth and preservation of its memory. Special attention is draw upon the Araguaia's Guerilla. Theoretically, the work intends to present the main aspects of Argumentation Theory trying to adapt it - as long as possible - to be used in Legal Argumentation. To fulfill this double objective, one applies Argumentation Theory to the Military Government events' discussions aiming for benefits both for theory and practice. Hence, it begins presenting the essential concepts and tools of Argumentation Theory. It follows with the tools adaptations to Legal Argumentation. Finally, the Argumentation Map of the discussions is presented. The problem whether the most severe crimes of the military personnel (tortures and executions for instance) were amnestied is dealt with in greater detail. The events of Araguaia's Guerrilla, the arguments of Brazilian Supreme Court in ADPF 153 and the arguments of the Inter-American Court of Human Rights in Gomes Lund v Brazil Case are all given special attention. The dissertation concludes that the military (State's agents) were not amnestied. It also points out the next steps in the discussions. As for the theoretical concerns, the conclusion draws attention to the importance of studying and developing Argumentation Theory in connection with Legal Argumentation.
\end{abstract}

Keywords: Brazilian Military Government, Araguaia's Guerrilla Warfare, Amnesty (Latin America), Argumentation Theory, Legal Argumentation. 


\section{SUMÁRIO}

INTRODUÇÃO: DA TEORIA À PRÁTICA E VICE-VERSA .13

CAPÍTULO I - O MODELO DE ARGUMENTAÇÃO DE WALTON 19

Seção I.1 - Conceitos Básicos 19

Seção I.1.A - Tipos de Generalização ..................................................................21

Seção I.1.B - Tipos de Inferência e Tipos de Argumentos .....................................26

Seção I.1.C - Ônus da Prova, Tipos de Premissas, Status das Premissas, Standards

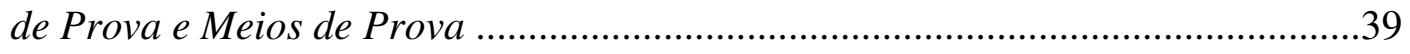

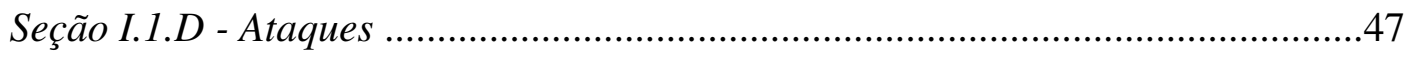

Seção I.1.E - Estágios do Diálogo e Tipos de Diálogo ............................................59

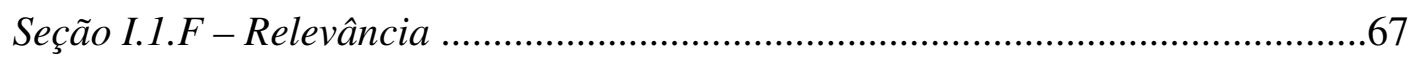

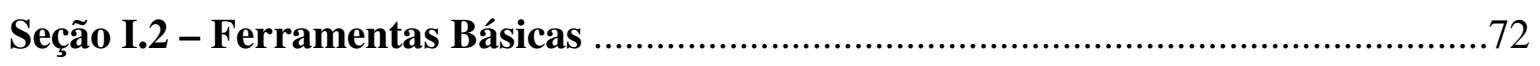

Seção I.2.A - Esquemas do Argumento ............................................................ 72

Seção I.2.A.i - Refinamento dos Esquemas .............................................75

Seção I.2.A.ii - Classificação dos Esquemas ..........................................87

Seção I.2.B - Reconstrução dos Argumentos ........................................................93

Seção I.2.C - Diagramação dos Argumentos .......................................................97

CAPÍTULO II - ARGUMENTAÇÃO JURÍDICA …………………………….........105

Seção II.1 - Algumas Características da Argumentação Jurídica .............................105

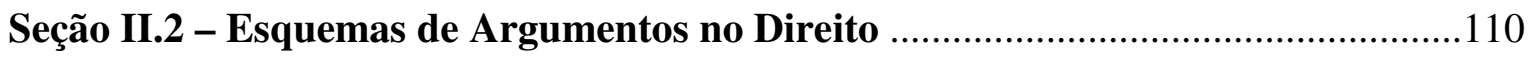

Seção II.2.A - Argumentos de Justificação .........................................................113

Seção II.2.A.i - Tradição, Justiça Formal e Aplicação de Normas Jurídicas

Seção II.2.A.ii - Posição de Saber .........................................................123

Seção II.2.A.iii - Pragmático e Objetivo da Lei .......................................126

Seção II.2.B - Argumentos de Operacionalização - Exceção ................................129

Seção II.2.C - Classificação de Esquemas da Argumentação Jurídica ................131 


\section{Seção III.1 - Uma Brevíssima História do Regime Militar, Torturas, Assassinatos e}

Desaparecimentos Políticos

Seção III.1.A - O Regime Militar: Repressão .......................................................139

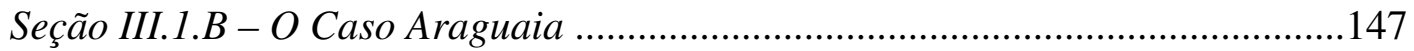

Seção III.1.C - O Processo Político de Anistia ........................................................150

Lei de Anistia (Lei $n^{\circ}$ 6.683/1979) ............................................................151

Lei dos Desaparecidos (Lei 9.140/1995) ................................................157

Lei do Anistiado Político (Lei 10.559/2002) .............................................166

Supremo Tribunal Federal e ADPF 153 ................................................169

Corte Interamericana de Direitos Humanos e o Caso Gomes Lund e outros

v. Brasil ("Guerrilha do Araguaia") .........................................................170

Comissão Nacional da Verdade (Lei 12.528/2011) ...................................172

Seção III.2 - Mapa Argumentativo em Protocolo de Disputas ...................................173

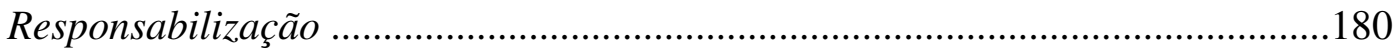

Responsabilização Penal ........................................................................180

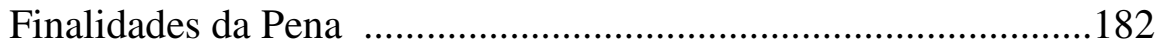

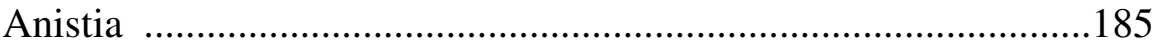

Correta Interpretação da Lei de Anistia .............................186

A Anistia dos Militares é Inválida .....................................197

Guerra de Fato e de Direito .................................................206

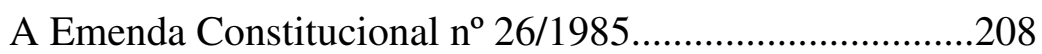

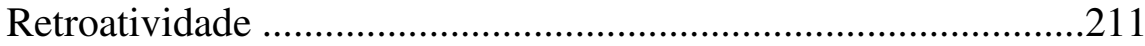

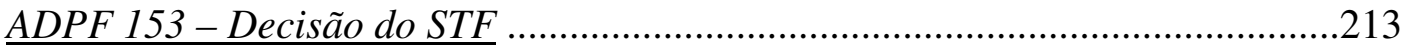

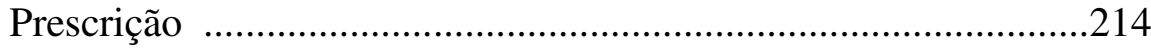

Provas e Responsabilidade Individual .......................................226

Responsabilização Administrativa .........................................................227

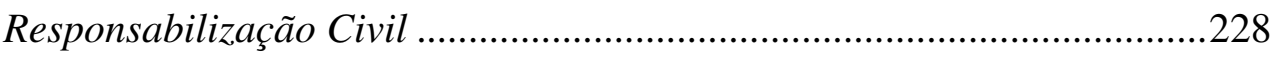

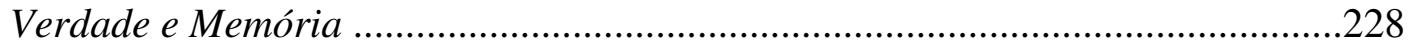


REFERÊNCIAS BIBLIOGRÁFICAS

APÊNDICE I - MAPA CONCEITUAL CAPÍTULO I

APÊNDICE II - MAPA CONCEITUAL CAPÍTULO II .259

APÊNDICE III - MATERIAL DE PESQUISA 267

APÊNDICE IV - MAPA ARGUMENTATIVO (DIAGRAMAS) 


\section{INTRODUCÃO: DA TEORIA À PRÁTICA E VICE -VERSA}

“Veja - O senhor já reencontrou alguma pessoa que torturou?

Araújo - Sim. Eventualmente, eu encontro ex-presos meus, inclusive os que apanharam. E o relacionamento não é muito ruim, não. Não é aquele negócio de dar beijinhos e abraços. Mas é um relacionamento de respeito. Há pouco tempo, aqui em Belo Horizonte, encontrei o Lamartine Sacramento Filho, que é professor em uma faculdade local. Segurei ele no ombro e disse: 'Você não me conhece, não?' Ele levou um susto. Aí eu disse: 'Você tá bom?' Ele disse que sim e não quis mais conversa. Mas também não passa batido, não (risos). Não deixo passar batido (sério).

Veja - Por quê?

Araújo - É o meu esquema. Não deixo passar batido. Não vai passar batido. Não passa batido. Vou lá, coloco a mão no ombro dele e digo: Não me esqueci de você, não. Você lembra de mim? Estamos aí. A vida continua.

Veja - Quantas pessoas o senhor já torturou?

Araújo - Não tenho idéia. Não sou igual a matador que faz talho na coronha do revólver para cada um que mata. Mas você quer um número aproximado?

Veja - Sim.

Araújo - Uns trinta."

(Trecho de entrevista concedida por Marcelo Paixão Araújo, tenente do $12^{\circ}$ Regimento de Infantaria do Exército em Belo Horizonte de 1968 a 1971, a Alexandre Oltramari, repórter da revista Veja, publicada em 09.12.1998 sob o título "Torturei uns trinta")

Os porões do regime militar são parte do imaginário popular brasileiro. A partir de determinada idade, todo mundo já ouviu falar das torturas, dos choques e do pau-de-arara. Muita gente também conhece histórias de execuções, desaparecimentos forçados e de guerrilheiros que formavam a oposição armada ao regime militar. Costuma-se falar ainda que em 1979 houve uma anistia recíproca que beneficiou os militares e a oposição armada. Anistia (do grego amnestia) significa esquecimento, dizem.

O esquecimento nunca ocorreu. As consequências de tudo isso estão bem vivas até hoje. Em 2010 foi julgada a Arguição de Descumprimento de Preceito Fundamental n $^{\text {o }}$ 153, pelo Supremo Tribunal Federal, que discutia se os militares também teriam sido beneficiados pela anistia. A ação foi julgada improcedente, entendendo-se que os militares foram anistiados. Mas a Ordem dos Advogados do Brasil, autora da ação, recorreu da 
decisão, que se encontra pendente de julgamento. Naquele ano, a Corte Interamericana de Direitos Humanos julgou o Caso Gomes Lund ("Guerrilha do Araguaia”) v. Brasil. Concluiu que o país estaria descumprindo sua obrigação internacional de investigar e punir os militares pelos crimes cometidos. Em 2012, o Tribunal de Justiça de São Paulo, por meio de decisão no processo $\mathrm{n}^{\mathrm{o}}$ 0347718-08.2009.8.26.0000, declarou o Coronel Carlos Alberto Brilhante Ustra torturador. Ainda há recursos. No mesmo ano, foi instalada a Comissão Nacional da Verdade, para investigar os acontecimentos do regime militar. A Comissão de Anistia do Ministério da Justiça, que paga indenizações a quem perdeu seu cargo por razões políticas, na época do regime militar, continua aceitando requerimentos e pagando indenizações.

Discute-se principalmente a responsabilização do Estado e dos militares pelos acontecimentos, bem como se busca esclarecer a verdade sobre o período e preservar sua memória. Apesar de terem permanecido vivas por tanto tempo, as discussões são fragmentárias, desorganizadas e frequentemente muito controvertidas, existindo opiniões as mais diversas. O primeiro objetivo deste trabalho é organizar os tópicos de discussão, delineando as questões a serem enfrentadas e estabelecendo o necessário diálogo entre os pontos de vista conflitantes. Trata-se de criar um quadro geral em que seja possível enxergar com clareza cada problema, onde ele se encaixa, as consequências de suas soluções para os outros problemas e pelo menos as principais linhas do seu enfrentamento.

Essa não é uma tarefa fácil, o que limita a amplitude e a profundidade do quadro. A quantidade de problemas diversos e de opiniões, somados à falta de diálogo e à falta de clareza, são os principais complicadores. A dificuldade se exacerba ao se discutir a possibilidade de responsabilizar criminalmente os militares. Simplesmente mergulhar nos debates sem um plano ou método prejudicaria os resultados do trabalho. A fragmentação, desorganização e controvérsias, aliás, podem ser em parte atribuídas a essa falta de método para se organizar e conduzir uma discussão. 
O problema da falta de método ultrapassa os limites das discussões sobre o regime militar brasileiro. Ele nos leva a fazer as seguintes perguntas teóricas de fundo: Como chegar à melhor resposta em casos difíceis? De que maneira enfrentar aqueles casos altamente controversos e complexos em que parece ser possível sustentar qualquer posição e impossível decidir qual é a correta?

Escolher a melhor resposta é uma tarefa essencialmente argumentativa que pode, portanto, se beneficiar da Teoria da Argumentação. Os desenvolvimentos mais recentes dessa área do conhecimento têm construído ferramentas que auxiliam os participantes de um diálogo a argumentar. Por meio das suas ferramentas, a Teoria da Argumentação fornece meios de realizar a análise crítica de argumentos existentes e a construção de novos argumentos a favor de uma tese.

Neste trabalho, nos valeremos da Teoria da Argumentação como instrumento de auxílio na busca da melhor resposta, como método para guiar a nossa análise do caso concreto, da teoria à prática. A sua utilização será precedida de uma exposição compreensiva de seus principais conceitos e ferramentas, o que se faz necessário especialmente considerando a sua falta de difusão no Brasil.

Sobre a aplicação da Teoria da Argumentação é fundamental fazer um esclarecimento. Não se trata de uma revolução na forma de argumentar, nem sequer de um método muito inovador. O alcance da Teoria da Argumentação é relativamente modesto. Ela auxilia na argumentação basicamente sistematizando e esclarecendo o modo pelo qual nós argumentamos. Por exemplo, o esquema do argumento, uma das principais ferramentas que a teoria oferece, nada mais faz que apresentar de maneira clara as premissas que compõem um tipo de argumento e as possíveis críticas que podem ser feitas a ele. A Teoria da Argumentação não nos desobriga de estudar o tema do qual estamos tratando nem de pensar com afinco nos casos concretos.

Apesar de modesta, a contribuição da Teoria da Argumentação é significativa. O estudo da teoria proporciona ganhos de clareza na construção e exposição da argumentação que facilitam o desenvolvimento do diálogo e a avaliação das teses debatidas. A conceptualização aprimorada das ideias de diálogo, de argumento e de ônus da prova, 
dentre outras, nos permite uma perspectiva privilegiada de avaliação de um debate. As ferramentas constituem o estado da arte da Teoria da Argumentação e permitem que as vantagens da sua utilização possam ser vistas de maneira mais imediata.

Necessário dizer que a Teoria da Argumentação não é algo definitivo e acabado. Muitos estudos estão sendo desenvolvidos, principalmente para aprimorar as suas ferramentas, que podem ser divididas em três grupos: os esquemas de argumento, as técnicas de reconstrução de argumentos e os métodos de diagramação. Os esquemas são as ferramentas primordiais que trabalham diretamente com a estrutura de um argumento, identificando-os e permitindo que se façam questões críticas para avaliar sua força e aplicabilidade em um caso concreto. A reconstrução serve para transformar um texto tornando-o mais adequado à análise pela Teoria da Argumentação e à utilização das outras ferramentas. Por fim, os métodos de diagramação servem à compreensão e visualização de uma discussão.

Uma das maneiras de contribuir para o desenvolvimento da Teoria da Argumentação e das suas ferramentas é justamente tentar aplicá-las para ver se funcionam, isto é, se realmente auxiliam o participante ou analista de um diálogo a identificar, analisar, avaliar e criar argumentos. Assim, a aplicação da Teoria da Argumentação ao caso difícil das discussões sobre o regime militar é uma via de mão-dupla: passa-se da teoria à prática e vice-versa, beneficiando ambas.

Diante desse benefício recíproco, o nosso trabalho possui um segundo objetivo: realizar uma exposição dos principais conceitos e ferramentas da Teoria da Argumentação, tentando contribuir para torná-la mais útil ao Direito. Relataremos algumas dificuldades de sua aplicação e faremos o esforço de adaptar algumas ferramentas às necessidades da argumentação jurídica, em vista de suas peculiaridades. Anote-se que nossas pretensões quanto a esse segundo objetivo são as mais modestas possíveis. O esforço serve mais para chamar a atenção à importância de desenvolver ferramentas úteis para o Direito do que para produzir algo muito elaborado. De qualquer modo, espera-se que ao menos a exposição compreensiva da Teoria da Argumentação já seja de alguma valia. 
O trabalho, portanto, possui um duplo objetivo. Para a prática, sistematizar as discussões sobre a responsabilização dos militares e do Estado por acontecimentos do regime militar, bem como sobre a busca da verdade e a preservação da memória. Para a teoria, apresentar os principais conceitos e ferramentas da Teoria da Argumentação, tentando adaptá-las na medida do possível para as necessidades da argumentação jurídica.

Para atender ao duplo objetivo, estruturou-se a dissertação em três capítulos. No Capítulo I (“O Modelo de Argumentação de Walton”), apresentaremos os principais conceitos e ferramentas da Teoria da Argumentação, tomando como base algumas obras de Douglas Walton, professor canadense que é referência mundial no assunto. Por conta da grande quantidade de conceitos a serem abordados e do caráter cumulativo da exposição, em que a compreensão de determinadas ideias depende da compreensão de outras, elaboramos o Apêndice I. Trata-se de um mapa conceitual que resume as conclusões de cada seção. Esperamos que ele sirva como guia de referência.

O Capítulo II (“Argumentação Jurídica”) é o mais curto e apresenta os resultados de nossos esforços para identificar aspectos da argumentação jurídica relevantes da perspectiva da Teoria da Argumentação. Assim, pode ser visto como uma continuação do Capítulo I, tendo sido separado por tratar especificamente das questões jurídicas. Nele também estão os resultados que obtivemos na tentativa de adaptar as ferramentas dos esquemas de argumento para o Direito e uma proposta simplificada de convenção para a ferramenta de diagramação. Tais resultados foram fruto de nossas reflexões após a tentativa de aplicação da teoria do Capítulo I ao caso do Capítulo III. As dificuldades em utilizar as ferramentas da Teoria da Argumentação na prática são muitas, mas esperamos que as nossas sugestões de adaptação sejam tão úteis para o leitor em casos práticos, quanto foram para nós ao elaborarmos o Capítulo III. Também foi elaborado um Apêndice II, nos mesmos moldes e com os mesmos objetivos do Apêndice I. Repita-se: é um trabalho incompleto e modesto, um esboço, mas ainda assim, útil. 
O Capítulo III (“O Caso Araguaia”) divide-se em duas grandes seções, em moldes similares aos de uma peça jurídica, tratando dos fatos e do direito. $\mathrm{Na}$ primeira, apresentamos de maneira sintética a história da repressão do regime militar e da oposição armada com destaque para seu mais conhecido movimento, a Guerrilha do Araguaia. Conta-se ainda o processo político de anistia - da busca pela superação de todos os acontecimentos - com ênfase nos processos de elaboração dos principais diplomas normativos que dispõem sobre o tema e na atuação dos principais órgãos governamentais.

A seção seguinte é a apresentação do Mapa Argumentativo, o primeiro objetivo deste trabalho. Serão delineadas as principais questões a serem enfrentadas e também os contornos do debate. Para o tópico mais controverso, a responsabilização penal dos militares, construiu-se um diálogo ideal entre duas partes, os Pró-Militares, contra a responsabilização penal e os Contra Militares, a favor da responsabilização penal. Para as questões sobre a efetiva anistia dos militares e sobre eventual retroatividade se fossem punidos hoje, o diálogo foi diagramado nos moldes da convenção proposta no Capítulo 2. Elegemos esses dois problemas para diagramação por serem o foco das discussões na ADPF 153 e no Caso Gomes Lund v. Brasil. As nossas conclusões sobre os debates serão expostas em cada subseção pertinente do Mapa.

As Conclusões realizam um balanço dos resultados obtidos para cada um dos objetivos deste trabalho, comentando uma possível agenda de pesquisa para dar continuidade. 


\section{CAPÍTULO I \\ O MODELO DE ARGUMENTAÇÃO DE WALTON}

O presente capítulo apresentará os principais problemas da teoria da argumentação a partir das reflexões de Douglas Walton, filósofo e lógico cuja obra está entre as mais importantes na literatura mundial sobre o tema. Nos basearemos principalmente: (a) no livro Fundamentals of Critical Argumentation de 2006 ("FCA"); (b) no livro Argumentation Schemes de 2008 (“소”), escrito em conjunto com Chris Reed e Fabrizio Macagno; e (c) nos textos sobre o modelo Carneades de argumentação e ônus da prova, escritos em conjunto com Thomas Gordon e Henry Prakken. Tais livros e textos são essenciais para fornecer um panorama da teoria de argumentação de Douglas Walton, incluindo seus desenvolvimentos mais recentes, bem como situar o estado da arte da teoria da argumentação.

\section{SEÇÃO I.1 CONCEITOS BÁSICOS}

A teoria da argumentação, segundo Walton, possui três objetivos: (a) identificar (identify); (b) analisar (analyse); e (c) avaliar (evaluate) argumentos (FCA, p. 1). Aos objetivos mencionados por Walton, podemos adicionar um quarto: (d) criar argumentos, pois as ferramentas da teoria da argumentação também auxiliam a pensar novos argumentos para resolver um problema.

O conceito mais elementar para uma teoria da argumentação é o conceito de argumento. Tradicionalmente, um argumento (argument) é definido como um conjunto de proposições dividido em premissas e conclusão, em que a partir das premissas e de um processo de inferência pode ser derivada a conclusão ${ }^{1}$. A essa visão, Walton opõe a de que argumentar seria dar razões para sustentar ou criticar uma proposição questionável, implicando a existência de um diálogo e de ao menos duas partes com visões diferentes sobre o problema. A argumentação seria então o processo dinâmico de conectar argumentos para algum propósito dentro do diálogo. (FCA, p.1) Podemos chamar a primeira perspectiva de estática ou lógica e a segunda perspectiva de dinâmica ou dialógica.

\footnotetext{
${ }^{1}$ Nesse sentido, ver, por exemplo, BENSON MATES. Elementary Logic. 2a Ed. New York: Oxford University Press, 1972, p.4-5.
} 
Tais perspectivas não são excludentes. Do ponto de vista da teoria da argumentação, ambas são fundamentais. Por vezes cria-se confusão em relação às perspectivas, pois é utilizado o mesmo termo - argument - para identificar realidades distintas. Para eliminar ambiguidades utilizaremos as seguintes definições:

Argumento é um sistema de proposições que nos permite, por meio de um processo de inferência, partir de uma proposição ou conjunto de proposições A, denominado premissa, para uma proposição B, denominada conclusão.

Argumentar é oferecer razões para sustentar ou criticar uma proposição.

Argumentação é o conjunto de argumentos oferecido pelas partes no diálogo para sustentar o seu ponto de vista.

A partir das definições que oferecemos, a próxima pergunta que se coloca é: O que é um diálogo? Um diálogo é uma conversação orientada por um objetivo, na qual dois participantes (no caso mínimo) agem por meio de turnos. O diálogo envolve uma questão (issue) a ser debatida e ao menos uma tese sobre essa questão (thesis). Cada participante apresenta um ponto de vista (viewpoint) sobre a questão. Para a existência do diálogo são necessários pelo menos dois pontos de vista diferentes e opostos. O diálogo progride por meio do uso de argumentos e é marcado pela civilidade (civility), ou seja, não há agressão física nem verbal entre os participantes (FCA, p.2-3). Cada intervenção de uma parte no diálogo é denominada passo (move). O diálogo e, portanto, cada um de seus passos, tem por objetivo resolver a questão dada.

Estabelecidos os objetivos e funções de uma teoria da argumentação, e definidos os conceitos elementares de argumento, argumentação e diálogo, podemos prosseguir na explanação dos conceitos básicos. 


\section{I.1.A Tipos de Generalização}

Na compreensão dos argumentos é essencial distinguir tipos de inferência que, conforme suas características, fornecem diferentes tipos de suporte à conclusão. Porém, antes de examinar cada tipo de inferência, devemos trabalhar o conceito de generalização e seus tipos, pois são as generalizações que determinarão o tipo de inferência.

Uma generalização (generalization) é uma afirmação que atribui alguma propriedade a um grupo de coisas individuais, definida em oposição a uma afirmação sobre uma coisa específica. Há três tipos de generalização: (a) generalização universal (universal generalization); (b) generalização indutiva (inductive generalization); e (c) generalização derrotável (presumptive defeasible generalization). (FCA, p. 15 e 18)

A generalização universal afirma alguma coisa sobre todos os indivíduos de um determinado tipo. Por exemplo, "todos os torcedores do Corinthians são sofredores". Quando a generalização já trata das exceções e qualificações de antemão, ela conserva seu caráter de universalidade. Por exemplo, "todos os torcedores do Corinthians, exceto os que não acompanham os jogos do time, são sofredores". Esse tipo de generalização também é conhecida como "absoluta" ou "estrita”, pois não admite exceções. (FCA, p. 17-18)

A generalização indutiva afirma que certo número de indivíduos (que pode ser especificado ou não) tem uma determinada propriedade. Ela pode ser numérica ou não numérica $^{2}$, caso possua, ou não, um número exato (ou intervalo numérico) ${ }^{3}$ determinado. Por exemplo, a generalização "a maioria dos corinthianos assistiu a um jogo no Pacaembu pelo menos uma vez na vida" não é numérica enquanto que "87.4 por cento dos corinthianos assistiu a um jogo no Pacaembu pelo menos uma vez na vida, com margem de erro de $2 \% "$ é numérica. (FCA, p. 17)

\footnotetext{
${ }^{2}$ Walton utiliza a terminologia "estatística" e "não-estatística", ao invés de "numérica" e "não-numérica". Conforme explicaremos adiante, há uma diferença entre esperança matemática e probabilidade observada (objeto de estudo mais comum da Estatística), apesar de ambas poderem ser utilizadas nas generalizações indutivas. Assim, entendemos melhor adaptar a terminologia.

3 A referência ao "intervalo numérico" não é feita por Walton, sendo incluída por nós dado que em estatística frequentemente se trabalha com intervalos numéricos e margens de erro.
} 
As generalizações indutivas indicam a probabilidade de que um indivíduo de determinado tipo apresente determinada propriedade. Probabilidade é entendida como algum número entre 0 e 1 que meça a possibilidade de que a proposição seja verdadeira ou falsa. Neste assunto, importante explicar a diferença entre esperança matemática e probabilidade observada. Para tanto, vamos discutir a seguinte questão: qual a probabilidade de uma pessoa ganhar no cara ou coroa lançando uma moeda? Quase todo mundo responderia de pronto: $50 \%$. No entanto, outros poderiam responder: depende.

Os $50 \%$ de probabilidade assumem que a moeda não seja viciada e que não haja nenhum fator externo a influenciar a jogada, traduzindo o que se espera de uma moeda em uma situação ideal. Assim, esse valor de 50\% é conhecido como esperança matemática. Ela se baseia apenas no fato de que existem duas possibilidades, assumindo que elas são equiprováveis. Caso a moeda seja jogada várias vezes a tendência esperada é de que $50 \%$ dos lançamentos resultem em cara e os outros $50 \%$ em coroa. Contudo, só se pode ter certeza de que essa distribuição ocorrerá para o caso de infinitos lançamentos.

Também é possível basear a probabilidade em observações. Pode-se lançar uma moeda muitas vezes e a partir daí verificar qual é a probabilidade de obter cara ou coroa para aquela moeda real e concreta, em determinada situação específica ou conjunto de situações. Para saber se uma moeda é viciada, um método é lançá-la várias vezes e observar os resultados, comparando-os em seguida com a esperança de 50\%, por meio de um procedimento estatístico denominado teste de hipóteses ${ }^{4}$. Uma moeda viciada terá uma chance diferente de $50 \%$ para cara ou coroa. No caso da probabilidade baseada em observações, assume-se que há uma incerteza quanto ao resultado do lançamento da moeda que pode distanciá-lo da esperança matemática, devido à influência de fatores externos que às vezes não sabemos sequer quais são. No entanto, entende-se também que essa incerteza pode ser mensurada, ainda que com algumas limitações ${ }^{5}$, e que ela se mantém consistente no tempo. Essa é a probabilidade estatística.

\footnotetext{
${ }^{4}$ Sobre o teste de hipóteses ver, por exemplo o Capítulo 9 "Testes de Hipóteses" do livro ANDERSON, David R.; SWEENEY, Dennis J.; WILLIAMS, Thomas A. Estatística Aplicada à Administração $e$ Economia. $2^{\text {a }}$ Ed. São Paulo: Cengage Learning, 2008.

${ }^{5}$ Para toda estatística amostral com a qual seja feita um teste, deve ser usada uma distribuição de base (N, F, $\mathrm{T}$ de Student, etc.) e deverá ser arbitrada uma significância estatística, que é a medida que nos permite saber o quão forte é a indicação fornecida por aquela amostra em um determinado sentido. A significância aponta para o fato de que as amostras nos deixam um componente de incerteza (ANDERSON, SWEENEY,
} 
Qual a relevância de distinguir entre as duas probabilidades? É importante saber que elas têm significados diferentes, e que, portanto, afirmações com base em cada tipo de probabilidade possuem um alcance diferente. Como consequência, o tipo de crítica à construção de uma esperança será diferente do tipo de crítica à construção de uma probabilidade observada. Em primeiro lugar, porque os argumentos utilizados para cada uma serão diferentes. Em segundo lugar, porque o significado daquela probabilidade muda, e o quanto podemos confiar nela como representativa da realidade, também.

Por fim, a generalização derrotável afirma que determinado tipo de indivíduo geralmente tem certa propriedade, estando essa afirmação sujeita a exceções. Ela recebe esse nome justamente por ter a característica de poder ser derrotada em casos especiais, mas ainda assim ser mantida para os casos típicos ou standard.

Para esse tipo de generalização distinguem-se as derrotas previsíveis e as imprevisíveis (predictable defeats, unpredictable defeats), sendo as imprevisíveis geralmente ligadas a casos concretos. Por exemplo, "O Corinthians geralmente ganha do Palmeiras" é uma generalização que pode ser derrotada em algum jogo no qual o árbitro marque um pênalti questionável, sendo essa uma derrota previsível, pois a arbitragem tende a tentar prejudicar um time do quilate do Corinthians. Contudo, a mesma generalização também pode ser derrotada se os jogadores do Corinthians acordarem algum dia dotados de espírito misericordioso e permitirem que o Palmeiras ganhe, só para variar, sendo essa uma ocorrência particular e imprevisível. Constata-se, assim, que, em ambas as hipóteses, a generalização derrotável sofre impacto pela adição de novas informações ao caso concreto. (FCA, p. 17-19 / p. 21) Claro que quais derrotas podem ser consideradas previsíveis ou imprevisíveis é uma questão sujeita a debate.

Um erro comum no uso da generalização derrotável é a chamada falácia da qualificação ignorada (fallacy of ignoring qualifications) ou falácia da generalização apressada (fallacy of hasty generalization). Consiste em sustentar erroneamente que a generalização se mantém por não se avaliar adequadamente as circunstâncias concretas que

WILliAMS, 2008, Capítulos 9, 12 (especialmente 12.5) e 13 (especialmente 13.5)). O conceito de margem de erro é outro indício. 
justificam o seu abandono. Costumam incorrer nesse erro aqueles que debatem de maneira muito apaixonada. (FCA, p. 19-20)

Ainda segundo Walton, há grande discussão na literatura sobre a diferença entre uma generalização indutiva e uma generalização derrotável. A diferença básica é que a generalização indutiva trata do número de ocorrências (instances) ou proporção de ocorrências de uma propriedade dentro de um grupo, enquanto que a generalização derrotável trata do que se pode esperar em uma situação ordinária ou familiar. Na última é impossível calcular ou antecipar o número exato de ocorrências positivas ou negativas de uma propriedade para um determinado grupo. São utilizadas em casos com quantidades gigantescas de dados, probabilidades desconhecidas ou situações em que as coisas mudam rapidamente. Em suma, a generalização derrotável é utilizada quando há déficit de conhecimento ou déficit de informação sobre um tema ou caso específico. (FCA, p. 18)

Os diferentes tipos de generalização apresentam ainda requisitos diferentes para serem sustentados ou criticados quanto às evidências. Os requisitos para sustentar uma generalização universal são grandes. Para mostrar isso retomemos a generalização universal de que "todos os torcedores do Corinthians são sofredores". Basta aparecer um torcedor do Corinthians que não seja sofredor que a generalização se torna falsa. De outro lado, para provar que a generalização indutiva " $75 \%$ dos torcedores do Corinthians são sofredores" é falsa, será necessário um estudo estatístico que mostre que $25 \%$ mais um dos torcedores do Corinthians não são sofredores. (FCA, p.19)

Talvez não seja possível fazer um estudo estatístico confiável sobre o Corinthians, seja porque os torcedores são muitos, seja porque a discussão está ocorrendo em uma mesa de bar, ou por qualquer outro motivo. Nesse caso, pode ser utilizada uma generalização derrotável, afirmando-se "geralmente os torcedores do Corinthians são sofredores". Os parâmetros de julgamento da generalização serão outros. Aquele que discordar da tese do corinthiano-sofredor-padrão pode trazer vários contra exemplos (counter example) de supostos corinthianos que não sofrem. 
O contra exemplo é um caso em que a regra posta pela generalização falha. Trata-se de uma afirmação particular porque diz respeito a uma ocorrência única. (FCA, p.15-16) Apesar de tratar de uma ocorrência única, o contra exemplo pode ser utilizado para criticar a generalização derrotável, indicando que ela é falsa. Outro uso possível do contra exemplo é mostrar que a interpretação de um caso concreto é mais adequada conforme o contra exemplo, por apresentar as mesmas peculiaridades, do que simplesmente conforme o estabelecido pela generalização derrotável.

Quanto ao primeiro uso do contra exemplo, o defensor da generalização pode atacar os contra exemplos, dizendo que são casos especiais de corinthianos que não sofrem e que, portanto, não são aptos a infirmar a generalização. Um deles pode ter muita sorte e só acompanhar os jogos em que o time ganha. Outro pode ser imune ao sofrimento porque não liga tanto para futebol. Assim, os contra exemplos seriam casos excepcionais que não tornariam falsa a generalização derrotável inicial de que "geralmente os torcedores do Corinthians são sofredores".

Sobre os requisitos de evidência para sustentar as generalizações, Walton se limita a dizer no FCA (p.19) que generalizações universais requerem mais evidências, generalizações indutivas, menos evidências, e derrotáveis, menos ainda. No entanto, nos parece importante destacar que, como mostrado acima, no caso de uma generalização derrotável, assumindo que não seja possível recolher evidências para sustentar outra espécie de generalização, o tipo de discussão que se instaura será diferente. O foco residirá na aptidão dos casos concretos utilizados como exemplo e contra exemplo para servirem como parâmetro do que é ordinário, ou seja, do que seria o caso padrão que está implícito na generalização. No exemplo dado, a crítica no fundo é de que não se pode esperar que a generalidade das pessoas tenha a sorte de só assistir aos jogos que o seu time ganha, e tampouco que as pessoas que são consideradas torcedoras não liguem tanto para futebol. A afirmação de que "geralmente os torcedores do Corinthians são sofredores" pressupõe uma imagem concreta de um torcedor padrão do Corinthians, de alguém que não possui tanta sorte e que é emocionalmente afetado pelos resultados do seu time. Em última instância, compara-se o exemplo dado a um exemplar imaginado, compara-se o caso concreto ao que chamaremos caso padrão. Claro que os diversos aspectos que compõem o caso padrão também podem ser objeto de discussão. 
Apesar de Walton não apresentar o conceito de caso padrão, entendemos que ele seja importante para a compreensão das generalizações derrotáveis e de outros conceitos e problemas que serão abordados mais adiante. Desse modo, o conceito de caso padrão também fará parte do repertório conceitual básico para uma teoria da argumentação do presente trabalho.

Por fim, ainda no assunto generalizações, é importante o conceito de afirmação existencial (existential statement). Trata-se de afirmação que diz que "pelo menos um indivíduo possui a propriedade/característica X". Não é considerada uma generalização, pois basta citar um caso para prová-la. No entanto, também não se considera uma afirmação singular, pois não faz uma afirmação sobre um caso específico, mas sobre a existência de casos. (FCA, p. 16)

\section{I.1.B Tipos de Inferência e Tipos de Argumentos}

Os argumentos podem ser classificados conforme o tipo de inferência que eles apresentam. São eles o argumento dedutivo, o argumento indutivo e o argumento derrotável. O tipo de inferência de um argumento está vinculado ao tipo de generalização que ele apresenta. Essa relação será abordada de maneira mais precisa ao final da seção. Primeiro, apresentaremos os tipos de argumento conforme o tipo de inferência.

No argumento dedutivo, se as premissas são verdadeiras, a conclusão é necessariamente verdadeira do ponto de vista lógico ${ }^{6}$. A ligação entre as premissas e a conclusão é, portanto, estrita. Em outras palavras, há validade dedutiva quando é logicamente impossível que as premissas sejam verdadeiras e a conclusão falsa ao mesmo tempo. Se o argumento dedutivo for estruturalmente correto diz-se que ele é válido e, no caso contrário, inválido. (FCA, p. 49/51)

\footnotetext{
${ }^{6}$ Em outra formulação tradicional, um argumento dedutivo é válido se e somente se seu condicional correspondente for necessariamente verdadeiro. Nesse sentido, BENSON MATES, 1972, p.7.
} 
Observe-se o seguinte exemplo de argumento dedutivo ${ }^{7}$ :

(Premissa Maior) Todos os corinthianos são sofredores.

(Premissa Menor) Sócrates é corinthiano.

(Conclusão) Logo, Sócrates é sofredor.

Podemos reescrever esse argumento na forma do seu condicional correspondente, a fim de mostrar com mais clareza a sua validade dedutiva. O condicional correspondente é obtido ao se colocar um argumento na forma "Se __, Então __, em que a primeira parte, conhecida como antecedente, é composta pelas premissas e a segunda parte, conhecida como consequente, é composta pela conclusão:

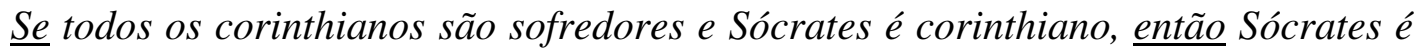
sofredor.

Se o antecedente é verdadeiro não há como dizer que o consequente é falso. Assim, trata-se de um argumento dedutivo válido. Geralmente, o fato de que uma das premissas é uma generalização universal (“Todos os corinthianos são sofredores”) é um bom indicador de que o argumento é dedutivo.

No argumento indutivo, se as premissas são verdadeiras a conclusão é provavelmente verdadeira, mas possivelmente falsa. A ligação entre as premissas e a conclusão não é tão estrita. Os argumentos indutivos são baseados em probabilidades, sendo a probabilidade entendida como algum número entre 0 e 1 que meça a possibilidade de que alguma proposição seja verdadeira ou falsa, como dito acima. Argumentos indutivos são mais fortes ou mais fracos, de acordo com a probabilidade de a conclusão ser verdadeira em virtude da probabilidade das premissas. (FCA, p. 50/51)

Observe-se o seguinte exemplo:

\footnotetext{
${ }^{7} \mathrm{O}$ exemplo mais tradicional é bastante parecido, mas diz que "Todos os homens são mortais" e "Sócrates é homem”, "Logo, Sócrates é mortal”. Entendemos importante prestar homenagem a outro Sócrates.
} 
(Premissa 1) 87,4\% dos corinthianos assistiu a um jogo no Pacaembu pelo menos uma vez na vida.

(Premissa 2) Sócrates é corinthiano.

(Conclusão) Sócrates (provavelmente) assistiu a um jogo no Pacaembu pelo menos uma vez na vida.

A probabilidade expressa na primeira premissa estará refletida na conclusão. Existem $87,4 \%$ de chance de a conclusão ser verdadeira. No entanto, para aguçarmos nossa compreensão sobre o argumento indutivo vale perguntar: É possível um argumento indutivo que não contenha em suas premissas probabilidades expressas em termos numéricos?

Assim como pode haver generalizações indutivas que não contenham números, pode haver argumentos indutivos que não contenham probabilidades expressas em termos numéricos em suas premissas. Por exemplo:

(Premissa 1) A maioria dos corinthianos assistiu a um jogo no Pacaembu pelo menos uma vez na vida.

(Premissa 2) Sócrates é corinthiano.

(Conclusão) Sócrates (provavelmente) assistiu a um jogo no Pacaembu pelo menos uma vez na vida.

Nesse novo exemplo não há probabilidade expressa em termos numéricos nem estatísticos. Contudo, o termo "maioria" indica que mais da metade do grupo que congrega todos os corinthianos assistiu a um jogo no Pacaembu pelo menos uma vez na vida. No fundo, há um conceito que pode ser expresso em termos numéricos: $50 \%+1$ dos corinthianos ou mais ${ }^{8}$.

\footnotetext{
${ }^{8}$ Assumindo que o total de corinthianos seja um número natural par e que, por consequência, 50\% dos corinthianos seja também um número natural. Caso o total de corinthianos seja um número natural ímpar, a maioria pode ser representada por $50 \%+0,5$.
} 
É importante perceber a diferença entre dizer "a maioria dos corinthianos..." e "geralmente os corinthianos...", pois ela indica a diferença entre uma generalização indutiva e uma generalização derrotável. A expressão "maioria" não faz distinção entre os corinthianos, uma vez que eles sejam classificados dentro do grupo dos corinthianos. Ela se preocupa apenas com a maioria dos elementos de um conjunto, sem levar em consideração outras propriedades que esses elementos (corinthianos) possam ter. $\mathrm{O}$ requisito para provar essa afirmação é a mera contagem dos corinthianos.

De outro lado, a expressão "geralmente" faz distinção entre os corinthianos. Se alguém dissesse "geralmente os corinthianos assistem a um jogo no Pacaembu pelo menos uma vez na vida" um opositor dessa tese poderia levantar contra exemplos de corinthianos que tivessem morrido sem nunca terem ido a um jogo no Pacaembu durante toda a vida. No entanto, a aptidão desses contra exemplos para criticar a generalização pode ser afastada. Por exemplo, um dos casos poderia ser o de um corinthiano que tivesse morado fora do Brasil a vida inteira e nunca tivesse tido condições financeiras de bancar uma viagem para cá. O defensor da generalização poderia então dizer que os corinthianos geralmente moram no Brasil e que, portanto, esse seria um caso excepcional que não serviria para tornar a generalização falsa, ainda que a derrotasse no caso concreto.

Mas e se quem atacasse a tese de que "geralmente os corinthianos assistem a um jogo no Pacaembu pelo menos uma vez na vida" trouxesse estatísticas absolutamente confiáveis, demonstrando que $75 \%$ dos corinthianos morrem sem nunca assistir a um jogo no Pacaembu? Nesse caso, a generalização derrotável seria tornada falsa, pois o conceito de "geralmente" envolve implicitamente um juízo sobre a "maioria" dos casos. Por que utilizar "geralmente" então? A expressão "geralmente" marca a utilização de uma generalização derrotável e, como já explicado, esse tipo de generalização é utilizado quando, por algum motivo, há um déficit de informação. Ou seja, não há como obter dados para sustentar uma generalização indutiva (e menos ainda uma absoluta). 
Para ajudar a esclarecer essas diferenças sutis, útil abordar o conceito estatístico de “moda”, que é o valor que ocorre com mais frequência em uma população ou amostra ${ }^{9}$. Por exemplo, em um armário há cinco camisas do Corinthians. Uma camisa com o número "1", três camisas com o número "7" e uma camisa com o número "99". A moda é o número “7”, já que ele apresenta três ocorrências. A moda não se confunde com a média ${ }^{10}$. A média dos números das camisas no caso seria 24,2:

$$
\frac{(1+7+7+7+99)}{5}=\frac{121}{5}=24,2
$$

Quando utilizamos a expressão "geralmente" no caso em debate, a ideia por trás é próxima à ideia de que a moda dos corinthianos assiste a um jogo no Pacaembu pelo menos uma vez na vida. Mas os corinthianos podem ser analisados sob mais de um aspecto e os corinthianos que assistem a um jogo no Pacaembu pelo menos uma vez na vida certamente possuem outras características em comum. Alguém que more fora do Brasil não serve para representar as outras características da moda dos elementos corinthianos e, portanto, não serve para derrubar a generalização. De outro lado, se alguém mostrar que $75 \%$ dos corinthianos morrem sem nunca assistir a um jogo no Pacaembu, restará demonstrado que a moda dos corinthianos não assiste a um jogo no Pacaembu pelo menos uma vez na vida. Apesar de elucidativo, não se afirma nem se sugere que o conceito de moda serve para representar o que se quer dizer por "geralmente" em todos os casos.

Por fim, vale apontar também que o fato de haver uma generalização indutiva como premissa não significa necessariamente que o argumento seja indutivo. Assim, o fato de uma premissa ser uma generalização indutiva é apenas um bom indicador de que um argumento seja indutivo. (FCA, p.50)

\footnotetext{
${ }^{9}$ Ao analisar os conceitos de "presunção" e "normal", Chaïm Perelman e Lucie Olbrechts-Tyteca também fazem referência ao conceito estatístico de "moda" para ajudar a elucidar o que estamos dizendo quando falamos que algo é "normal". Na referência bibliográfica a seguir, tomem cuidado com a falha de tradução que utilizou erroneamente a expressão "modo" e não "moda". PERELMAN, Chaïm e OLBRECHTSTYTECA, Lucie. Tratado da Argumentação: A Nova Retórica São Paulo: Martins Fontes, 2ª Ed., 2005, § 17 As Presunções, p.79-83

${ }^{10}$ No exemplo, tratamos da média aritmética simples, dada pelo somatório do valor dos termos, dividida pelo número de termos.
} 
No argumento derrotável, a conclusão é plausível ${ }^{11}$. Plausível significa que ela parece verdadeira, dadas as aparências do caso, ou seja, dadas as informações e conhecimentos dos quais se dispõe em um momento determinado. Esse tipo de inferência é denominada derrotável (defeasible), pois ela pode falhar se novas evidências surgirem. Apesar de menos preciso e confiável que os outros dois tipos de argumento, o argumento derrotável é geralmente o mais útil, sendo necessário para condução prática das questões da vida cotidiana. (FCA, p.52)

Observe-se o exemplo:

(Premissa 1) Os corinthianos geralmente assistem a um jogo no Pacaembu pelo menos uma vez na vida.

(Premissa 2) Sócrates é corinthiano.

(Conclusão) Sócrates (plausivelmente) assistiu a um jogo no Pacaembu pelo menos uma vez na vida.

A conclusão é plausível, contudo, caso sejam obtidas novas informações sobre Sócrates, ela pode mudar. Vamos supor que Sócrates tenha nascido fora do Brasil e more fora do Brasil. No mínimo, a plausibilidade da conclusão se tornará menor. Se soubermos ainda que Sócrates não tem muito dinheiro e não pertence a uma família abastada, a plausibilidade se tornará ainda menor, pois será difícil que Sócrates tivesse a oportunidade de pagar uma passagem para o Brasil para ver o Corinthians jogar no Pacaembu.

Podemos ainda receber a informação de que Sócrates nunca tenha viajado ao Brasil. Nesse caso, a conclusão seria tornada falsa por um argumento dedutivo no sentido oposto ao do argumento derrotável. A nova informação derrotaria definitivamente o argumento:

11 Walton diz que a conclusão plausível e pode ser aceita provisoriamente como uma presunção (presumption). Mais adiante trataremos do conceito de presunção ao classificar proposições quanto ao ônus da prova. Não se trata da mesma coisa. Aqui Walton pretende apenas enfatizar a fraqueza dos argumentos derrotáveis quando comparados com os argumentos dedutivos ou indutivos e por isso fala em presunção. Argumentos derrotáveis podem permitir a conclusão definitiva de um diálogo e a conclusão sustentada por um argumento derrotável pode ser classificada como uma premissa ordinária ou de outra maneira (quanto ao ônus da prova). Para evitar confusões, optamos por excluir da nossa explicação a nomenclatura utilizada pelo autor e a expressão de aceitação provisória. 
(Premissa 1) É fisicamente impossível assistir a um jogo do Corinthians no Pacaembu sem vir ao Brasil.

(Premissa 2) Sócrates nunca veio ao Brasil.

(Conclusão) Sócrates nunca assistiu a um jogo no Pacaembu.

Com base nesses exemplos, podemos estabelecer com maior precisão o significado de "novas evidências" que derrotem o argumento. Trata-se de novas premissas que podem ser adicionadas sem alterar o valor de verdade das premissas anteriores. Essas novas premissas se referem a novas informações ou a novos conhecimentos relevantes ${ }^{12}$. "Novas" e "novos", aqui, não querem dizer que eles tenham sido descobertos pouco antes de serem enunciados, mas, sim, que foram introduzidos no diálogo apenas naquele momento. No exemplo acima, a Premissa 2 é baseada em uma nova informação, e a Premissa 1, baseada em um novo conhecimento, tendo sido trazidas ao diálogo para formar um argumento dedutivo que prove a falsidade da conclusão do argumento derrotável a que se opõem.

É importante frisar que a derrota se dá pela adição de novas premissas que não alteram o valor de verdade das premissas anteriores. Caso não seja feita essa distinção, o critério não serve para distinguir o argumento derrotável dos outros. Qualquer argumento pode ser atacado e tornado inválido, improvável ou implausível por meio de um ataque ao valor de verdade das suas premissas. Retomemos os exemplos acima de argumento dedutivo e argumento indutivo:

\section{$\underline{\text { Dedutivo }}$}

(Premissa 1) Todos os corinthianos assistiram a um jogo no Pacaembu pelo menos uma vez na vida.

(Premissa 2) Sócrates é corinthiano.

(Conclusão) Sócrates (necessariamente) assistiu a um jogo no Pacaembu pelo menos uma vez na vida.

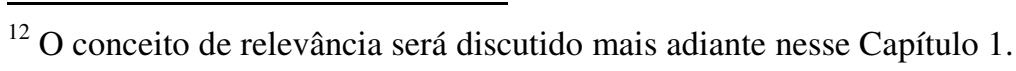




\section{$\underline{\text { Indutivo }}$}

(Premissa 1) 87,4\% dos corinthianos assistiu a um jogo no Pacaembu pelo menos uma vez na vida.

(Premissa 2) Sócrates é corinthiano.

(Conclusão) Sócrates (provavelmente) assistiu a um jogo no Pacaembu pelo menos uma vez na vida.

Em qualquer dos casos, se tornarmos o valor de verdade da Premissa 2 falsa, ou seja, se mostrarmos que Sócrates não é corinthiano, o argumento perde toda sua força. Por exemplo, se for descoberta uma prova de que na verdade Sócrates é palmeirense, e essa informação for introduzida no diálogo, alguém poderá dizer que se trata de uma "nova informação", pois acaba de ser introduzida, e, assim, será uma nova evidência "derrotando" argumentos que não são do tipo derrotável. Por esse motivo, é necessário esclarecer o sentido de "novas evidências" nos termos expostos acima. Também é importante, para evitar ambiguidades, resguardar o uso do termo "derrotar" com o sentido de atacar e vencer um argumento, apenas para os casos de argumentos derrotáveis. O modo como funcionam os ataques e a terminologia precisa a ser utilizada serão expostos em seção mais adiante nesse capítulo. Devemos observar ainda que se Sócrates é efetivamente corinthiano ou palmeirense pode depender de outros argumentos, que farão parte da argumentação do caso.

Mas apesar de Walton (FCA, p.52) enfatizar a questão das novas evidências como meio de vencer um argumento derrotável, cabe a pergunta: essa é uma ideia precisa? O sentido de "novas evidências" exposto acima é suficiente para distinguir o argumento derrotável dos outros tipos de argumento? Entendemos que não. Para isso retomemos o seguinte exemplo de argumento indutivo:

(Premissa 1) 87,4\% dos corinthianos assistiu a um jogo no Pacaembu pelo menos uma vez na vida.

(Premissa 2) Sócrates é corinthiano.

(Conclusão) Sócrates (provavelmente, 87,4\% de chance) assistiu a um jogo no Pacaembu pelo menos uma vez na vida. 
Durante a discussão podem ser trazidas novas evidências: a informação de que Sócrates mora a mais de $100 \mathrm{~km}$ do estádio do Pacaembu (Premissa 3), e o conhecimento de que apenas $10 \%$ dos corinthianos que moram a mais de $100 \mathrm{~km}$ do Pacaembu assistem a um jogo lá pelo menos uma vez na vida (Premissa 4). Assim:

(Premissa 1) 87,4\% dos corinthianos assistiu a um jogo no Pacaembu pelo menos uma vez na vida.

(Premissa 2) Sócrates é corinthiano.

(Premissa 3) Sócrates mora a mais de $100 \mathrm{~km}$ do Pacaembu.

(Premissa 4) Apenas $10 \%$ dos corinthianos que moram a mais de $100 \mathrm{~km}$ do Pacaembu assistem a um jogo lá pelo menos uma vez na vida.

(Conclusão) Sócrates (provavelmente, $10 \%$ de chance) assistiu a um jogo no Pacaembu pelo menos uma vez na vida.

Observe-se que o valor de verdade da Premissa 1 e da Premissa 2 não foi alterado. No entanto, o suporte à conclusão mudou. De $87,4 \%$ de chance da conclusão estar certa, agora temos apenas $10 \%$. Pode-se até discutir se na linguagem ordinária seria apropriado dizer "provavelmente" para um caso de apenas $10 \%$ de chance. Mas, aqui, "provavelmente" está no sentido técnico, indicando o tipo de inferência do argumento, sem qualquer juízo sobre a força do argumento.

O exemplo mostra um argumento indutivo que foi afetado por novas evidências que não alteraram o valor de verdade das premissas anteriores. Poderíamos modificar o exemplo, dizendo que Sócrates mora a $5000 \mathrm{~km}$ de distância e que $0 \%$ dos corinthianos que moram a essa distância assistem a um jogo no Pacaembu pelo menos uma vez na vida. Nesse caso, a conclusão seria falsa e não apenas pouco provável. Assim, fica claro que a adição de novas evidências como meio de vencer um argumento não é critério suficiente para distinguir o argumento derrotável do argumento indutivo. Mas então como distinguir os tipos de argumento? 
O tipo de inferência (e, consequentemente, o tipo do argumento) depende da generalização que o argumento apresente como garantia ${ }^{13}$. A garantia é uma função especial que uma generalização cumpre dentro da estrutura do argumento. É a garantia que autoriza a inferência. Por exemplo:

\section{(Premissa) Sócrates é corinthiano. \\ (Conclusão) Logo, Sócrates é sofredor.}

Pela leitura, percebe-se que falta alguma coisa que permita essa conclusão. Alguém que ouvisse esse argumento e pouco soubesse de futebol poderia perguntar "Por que o fato de Sócrates ser corinthiano implica ele ser sofredor?". A resposta poderia ser a generalização universal:

(Premissa) (Porque) todos os corinthianos são sofredores.

Sem a generalização universal autorizando a inferência, não haveria inferência dedutiva $^{14}$. Claro, sem a premissa "Sócrates é corinthiano" a inferência também não existiria, mas é a generalização que determina o tipo do argumento e a natureza da inferência. Veja-se o seguinte exemplo:

\section{(Premissa) Sócrates é corinthiano.}

(Conclusão) Sócrates assistiu a um jogo no Pacaembu pelo menos uma vez na vida.

Após a pergunta "Por que o fato de Sócrates ser corinthiano implica ele ter assistido a um jogo no Pacaembu pelo menos uma vez na vida?", a resposta poderia ser:

\footnotetext{
${ }^{13}$ O conceito de garantia (warrant) foi apresentado por Stephen Toulmin no livro "Os Usos do Argumento" como um dos principais conceitos do seu famoso modelo de argumentação. Toulmin não fala expressamente de uma relação entre garantias e generalizações, e Walton também não. No entanto, acreditamos importante utilizar o conceito para mostrar como algumas generalizações apresentam uma função especial na estrutura do argumento determinando o tipo de argumento com o qual estamos lidando. Para o conceito de garantia tal como entendido por Toulmin, ver TOULMIN, Stephen. Os usos do argumento. $2^{\text {a }}$ Ed. São Paulo: Martins Fontes, 2006, especialmente p. 139-147

${ }^{14}$ Não se nega com isso a possibilidade de que argumentações reais sejam desenvolvidas com base em argumentos incompletos (entimemáticos), dotados de apenas uma premissa.
} 
(Premissa) (Porque) 87,4\% dos corinthianos assistiu a um jogo no Pacaembu pelo menos uma vez na vida.

Nesse caso teremos um argumento indutivo. Ele é indutivo porque se baseia em uma generalização indutiva que autoriza a inferência. Ou seja, porque a sua garantia é uma generalização indutiva.

Há casos em que um argumento pode ser apresentado com várias generalizações de tipos diferentes, mas apenas uma delas é a garantia, e será esta que determinará o tipo de argumento.

(Generalização dedutiva) Todos os torcedores do Corinthians que têm mais de 18 anos e assistem a um jogo do Corinthians no Pacaembu são sofredores.

(Generalização derrotável) Geralmente os torcedores do Corinthians que assistem ao jogo vestindo a camisa do time são sofredores.

(Afirmação específica) Após completar 18 anos, Sócrates assistiu a todos os jogos do Corinthians no Pacaembu vestindo a camisa do time.

(Conclusão) Sócrates (necessariamente) é um sofredor.

Há duas generalizações no argumento apresentado. Uma do tipo universal e outra do tipo derrotável. No entanto, apenas uma delas funciona como garantia, a do tipo universal, e é ela que determina o tipo de inferência. Caso a generalização derrotável fosse substituída por uma generalização indutiva " $74,6 \%$ dos torcedores do Corinthians que assistem ao jogo vestindo a camisa do time são sofredores", a conclusão se manteria inalterada. Isso porque o argumento tal qual apresentado poderia ser desmembrado em dois argumentos, um dedutivo e outro indutivo, sendo que o dedutivo prevalece e estabelece a conclusão, funcionando como a efetiva garantia.

Essa discussão mostra que a presença da generalização de um determinado tipo em um argumento é um bom indicativo de que o argumento é do tipo correspondente. No entanto, a identificação não é necessária, pois podem haver generalizações de tipos diferentes e só uma funcionará como garantia. 
Nem sempre será fácil identificar a generalização que está exercendo o papel de garantia. A generalização pode estar implícita ou podem haver várias generalizações nos obrigando a olhar para o contexto de apresentação do argumento. Contudo, identificar a generalização que exerce o papel de garantia é fundamental para se identificar adequadamente o tipo de argumento e o tipo de inferência com o qual estamos lidando.

Para mostrar que não é possível pensar um argumento de um determinado tipo sem uma garantia correspondente, voltemos ao argumento dedutivo. Todo argumento dedutivo dependerá de uma generalização universal. Como mostrar isso? Tentemos imaginar um argumento dedutivo sem uma generalização universal. $\mathrm{O}$ critério para que um argumento seja considerado dedutivo é que ele não permita que as premissas sejam verdadeiras e a conclusão seja falsa ao mesmo tempo. Sempre que for possível adicionar novas premissas relevantes, será possível tornar a conclusão falsa ou mudar o suporte das premissas à conclusão. Então, para que um argumento seja dedutivo não pode ser possível adicionar novas premissas. A generalização universal estabelece esse constrangimento. Ela se referirá a uma propriedade $\mathrm{X}$ comum a todos os elementos de um conjunto. Assim, pouco importa que outras propriedades $\mathrm{Y}$ eles tenham, elas não poderão ser usadas para diminuir a probabilidade de que $\mathrm{X}$ seja uma propriedade desses elementos.

Exemplificando. Se é verdade que todos os corinthianos são sofredores, e é verdade que Sócrates é corinthiano, ele necessariamente será sofredor. Pouco importa se Sócrates mora perto ou longe do Pacaembu, se já assistiu ou não assistiu a um jogo no Pacaembu, se ele é rico, pobre, tem 2 metros de altura, graduação em medicina, etc. Nenhuma dessas propriedades poderá afetar a conclusão sobre a primeira propriedade (sofredor). No entanto, se nem todos os corinthianos forem sofredores, e Sócrates for corinthiano, o que determinará que ele seja sofredor? Duas opções. Pode ser aleatório, e então estaremos no domínio da probabilidade, e o suporte à conclusão não será dedutivo. Pode depender de alguns fatores, e então estaremos no domínio da probabilidade e da plausibilidade. $\mathrm{Na}$ última hipótese, dependerá da adição de novas premissas que alterem o suporte à conclusão. Só chegaremos a uma combinação de fatores que estabeleça 100\% de certeza, quando adicionarmos uma generalização universal dizendo que $100 \%$ dos casos que 
reúnam todos esses fatores possuem a propriedade em debate. E então não poderão ser adicionadas novas premissas ${ }^{15}$. Por exemplo:

(Premissa 1) Sócrates é corinthiano.

(Premissa 2) Sócrates mora a menos de $1 \mathrm{~km}$ do Pacaembu.

(Premissa 3) Sócrates possui renda superior a $R \$$ 5.000,00 líquidos por mês.

(Conclusão) Sócrates assistiu a pelo menos um jogo no Pacaembu em sua vida.

O suporte à conclusão só a tornará necessária caso adicionemos alguma generalização universal funcionando como garantia. Do mesmo modo um argumento só será indutivo ou derrotável conforme apresente como garantia uma generalização dessa natureza.

Walton observa que tanto métodos dedutivos quanto indutivos podem ser avaliados usando métodos exatos de cálculo. (FCA, p. 52) Destacamos que a avaliação dos métodos indutivos variará conforme se tratem de probabilidades matemáticas ou estatísticas.

Por fim, é importante observar a utilidade de se avaliar um argumento pelos parâmetros do argumento dedutivo, do indutivo, ou do derrotável. Por exemplo, um argumento dedutivo pode ser visto como um caso especial do argumento indutivo em que a probabilidade da verdade da conclusão é 1.0. No entanto, nesses casos é mais simples e mais útil simplesmente dizer que ele é dedutivo, e utilizar as técnicas de avaliação de argumentos dedutivos em vez das de argumentos indutivos. Outro exemplo: se um argumento pode ser avaliado precisamente por métodos indutivos, não será muito eficaz utilizar métodos de avaliação do argumento derrotável no caso. (FCA, p.53) Por fim, utilizar probabilidades pode ser um meio ruim de avaliar um caso concreto, se houver informações ou conhecimentos que não tenham sido considerados na construção das probabilidades.

${ }^{15}$ Sempre poderão ser adicionadas premissas irrelevantes, mas elas não entram no conceito de "novas evidências" estabelecido acima. A relevância será tratada mais adiante nesse Capítulo. 
Feitas essas considerações, na ordem, métodos derrotáveis cedem para métodos indutivos e métodos indutivos cedem para métodos dedutivos, quando for o caso (possível e útil) de aplicar cada método. (FCA, p.53)

A tabela a seguir resume as características dos tipos de argumento discutidos:

\begin{tabular}{|l|l|l|}
\hline \multicolumn{1}{|c|}{ Tipo / Garantia } & \multicolumn{1}{|c|}{ Suporte à Conclusão } & \multicolumn{1}{c|}{ Utilização } \\
\hline Dedutivo & Necessidade & Válido ou Inválido \\
\hline Indutivo & Probabilidade (de 0 a 1) & Probabilidades \\
\hline Derrotável & Plausibilidade & Déficit de conhecimento/informação \\
\hline
\end{tabular}

\section{I.1.C Ônus da Prova, Tipos de Premissas, Status das Premissas, Standards de}

\section{Prova e Meios de Prova}

Outro problema fundamental para uma teoria da argumentação é o do ônus da prova, ou seja, o de quem tem o dever de provar ou sustentar uma determinada premissa em debate, sob pena dela não ser tida como verdadeira. A noção de ônus da prova, apesar de simples, é importantíssima, pois cumpre papel fundamental na determinação da tese que será vencedora em um diálogo, especialmente nos processos instaurados perante o Judiciário.

Quem estuda e trabalha com Direito certamente está familiarizado com o conceito de ônus de prova e com a noção de que "Quem alega, prova" tenta condenar alguém por ter cometido um crime de assassinato, cabe à acusação provar que o crime ocorreu e que o acusado é o culpado. Por exemplo, no Brasil, se tentarem acusar Sócrates de ter matado Tostão, deverá ser localizado o corpo da vítima (Tostão) a fim de mostrar que o homicídio ocorreu ${ }^{17}$.

\footnotetext{
${ }^{16}$ Presente, por exemplo, no Art. 156 do Código de Processo Penal Brasileiro e no Art. 333 do Código de Processo Civil Brasileiro.

${ }^{17}$ Em termos técnicos, a materialidade do crime deverá ser provada por meio do exame de corpo delito, indispensável quando a infração penal deixar vestígios, nos termos do Art. 158 do Código de Processo Penal (Decreto Lei no $3.689 / 1941)$.
} 
A observação de como se processam diálogos nos permite classificar diferentes tipos de premissas de acordo com o ônus da prova que lhes é associado. Walton, Gordon e Prakken distinguem premissas ordinárias (ordinary), suposições ${ }^{18}$ (assumptions) e exceções (exceptions) $)^{19}$.

Antes de explicar a classificação, porém, precisaremos adiantar um pouco o assunto da próxima seção, a fim de dizer que o valor de verdade de uma premissa pode ser atacado de duas formas: (a) a premissa pode ser simplesmente questionada; ou (b) à premissa afirmada pode ser contraposta premissa com valor de verdade oposto. Por exemplo, imaginemos a afirmação de que "Sócrates jogava futebol melhor que Biro Biro". Essa afirmação pode ser questionada "Sócrates realmente jogava futebol melhor que Biro Biro?". Ou essa afirmação pode ser contraditada "Sócrates não jogava futebol melhor que Biro Biro" ${ }^{20}$. São dois ataques que possuem significados e alcances diferentes, apresentando diferença em contextos práticos.

As premissas ordinárias são aquelas que dependem de provas adicionais para serem consideradas verdadeiras. Para serem tornadas falsas também necessitarão de evidências em contrário, não bastando o mero questionamento.

As suposições são premissas que se assumem como verdadeiras até o momento em que elas são questionadas. Após serem questionadas, serão tornadas falsas ou neutras e dependerão de provas adicionais para serem aceitas como verdadeiras.

\footnotetext{
${ }^{18}$ Optamos pela tradução "suposição" ao invés de "presunção", pois "presunção" em Direito possui significado diferente, seja uma presunção absoluta ou relativa. Além disso, mais adiante definiremos outros dois tipos de premissas a partir do conceito jurídico de presunção.

${ }^{19}$ GORDON, Thomas F.; PRAKKEN, Henry; e WALTON, Douglas. The Carneades model of argument and burden of proof. Artificial Intelligence, 171, 10-11 (2007), p. 875-896. Disponível em http://www.tfgordon.de/publications. Acesso em 01 de fevereiro de 2012, p.7 e p.10

${ }^{20}$ Podemos pensar ainda na possibilidade de alguém dizer que "Biro Biro jogava futebol melhor do que Sócrates". Isso é dizer mais do que "Sócrates não jogava futebol melhor do que Biro Biro", pois esta última frase permite dizer que Sócrates jogava futebol tão bem quanto Biro Biro, estando os dois no mesmo nível. De qualquer modo, ao dizer que Biro Biro jogava melhor do que Sócrates, estamos dizendo que é falso que Sócrates jogava melhor que Biro Biro, pois ao sabermos o significado de "melhor" sabemos que não é possível as duas afirmações serem verdadeiras ao mesmo tempo. Esse exemplo, no entanto, é mais complexo, e envolve uma discussão sobre o que se entende por oposição entre afirmações, ou seja, uma teoria das oposições. Para fins deste trabalho, vamos deixar essas questões de lado. Algumas teorias das oposições são mencionadas e discutidas em WALTON, REED, MACAGNO, 2008, p.247-251.
} 
As exceções são premissas que se assumem como falsas até o momento em que se fazem provas em sentido contrário. O questionamento da exceção é incapaz de alterar o seu valor de verdade.

Inspirados pelo Direito, entendemos que, além dessas, outras duas categorias de premissas podem ser identificadas. As presunções relativas são premissas que se assumem como verdadeiras até o momento em que se fazem provas em sentido contrário. As presunções absolutas são premissas que se assumem como verdadeiras, independentemente de questionamento ou provas em sentido contrário.

As diferenças entre os tipos de premissas são importantes para a compreensão de um diálogo, pois em momentos diferentes as premissas terão status diferentes. No exemplo do homicídio de Tostão por Sócrates, referido acima, a acusação, ao iniciar o processo alega, dentre outras coisas, que Tostão está morto. De acordo com a regra jurídica do Art. 156 do Código de Processo Penal Brasileiro, quem alega deve provar. Assim, a mera alegação é insuficiente para tornar a premissa aceita como verdadeira. Nesse primeiro momento, a premissa não é aceita como verdadeira nem rejeitada como falsa, podendo ser denominada neutra.

Em um segundo momento, a acusação pode trazer fotos do corpo de Tostão e o Laudo do Instituto Médico Legal comprovando a sua morte por traumatismo craniano. O juiz pode acolher as provas como verdadeiras e suficientes para se estabelecer que Tostão realmente está morto. Nesse segundo momento, a premissa foi aceita como verdadeira.

Em um terceiro momento, a defesa pode questionar a premissa de que Tostão está morto, prometendo demonstrar sua falsidade em audiência. Nesse momento a premissa encontra-se questionada, mas pela ausência de evidências a dar suporte ao questionamento, permanece aceita como verdadeira.

Em um quarto momento, a defesa pode mostrar por meio de assistente técnico que as fotos não são do corpo de Tostão, mas de outra pessoa, e arguir que o Laudo seria falso, tendo sido fabricado por um funcionário corrupto do Instituto Médico Legal. Por fim, 
como prova cabal de que Tostão está vivo, a defesa pode trazê-lo ao Tribunal, causando espanto. Nesse quarto momento, o juiz reconsidera seu entendimento e a premissa passa a ser rejeitada como falsa.

A premissa de que Tostão estava morto era do tipo ordinária, pois dependia de evidências para que fosse aceita como verdadeira, bem como de evidências para que fosse rejeitada como falsa, não bastando o mero questionamento. $\mathrm{O}$ exemplo mostra como a classificação das premissas ganha sentido quando analisamos a mudança de seu status em um diálogo ao longo do tempo. Mostra ainda que, quando enunciada, a premissa possui um status prima facie, bem como põe em evidência os possíveis fatores que podem alterar o status da premissa, notadamente, as provas a favor, o questionamento e as provas em contrário.

Podemos ver as diferenças entre cada tipo de premissa claramente no quadro abaixo. O quadro destaca, em cada momento do diálogo, o status da premissa, que pode ser verdadeira, falsa ou neutra. O campo "prima facie" mostra qual o status da premissa após ela ser enunciada. O campo "prova (+)" mostra o status após a prova positiva da premissa. O campo "questionamento" mostra o status da premissa após ser questionada. O campo "prova (-)" mostra o status da premissa após a prova negativa da premissa.

\begin{tabular}{|l|l|l|l|l|l|}
\hline Tipo & Prima Facie & Prova (+) & Questionamento & Prova (-) \\
\hline Ordinária & Neutra & Verdadeira & Neutra & Falsa \\
\hline Suposição & Verdadeira & Verdadeira & Neutra/Falsa & Falsa \\
\hline Exceção & Falsa & Verdadeira & Falsa & Falsa \\
\hline Presunção Relativa & Verdadeira & Verdadeira & Verdadeira & Falsa \\
\hline Presunção Absoluta & Verdadeira & Verdadeira & Verdadeira & Verdadeira \\
\hline
\end{tabular}

Sobre o quadro e as distinções traçadas cabem algumas observações. Em primeiro lugar, vale observar que a classificação das premissas e o seu status são atribuídos pelo analista, apesar de poderem ser objeto de discussão entre as partes do diálogo. O analista assume o ponto de vista de um terceiro que observa o diálogo de fora imparcialmente e se pauta pelo melhor uso possível da teoria da argumentação e das regras da argumentação. 
Em segundo lugar, Walton, Gordon e Prakken definem o status das premissas de forma diferente, classificando-as em enunciadas (stated), questionadas (questioned), aceitas (accepted) e rejeitadas (rejected $)^{21}$. Ao realizar a classificação, os autores não deixam claro se o ponto de vista para estabelecer o status é o do analista ou o das partes. É importante ter clareza sobre esse ponto, pois a avaliação e a classificação das premissas e dos argumentos pelas partes do diálogo não serão necessariamente iguais às do analista, especialmente em diálogos reais.

Uma premissa aceita por ambas as partes pode ser considerada falsa pelo analista e uma premissa rejeitada pelas partes pode ser considerada verdadeira. O foco de preocupação da análise ao se observar se as partes aceitaram ou rejeitaram as premissas é diferente do foco ao se examinar se as premissas são verdadeiras, neutras ou falsas. Apesar das informações sobre a aceitação ou rejeição pelas partes ser relevante, reiteramos que aqui se adota o foco do analista, tendo por objetivo contrastar a argumentação realizada com o que dispõe a teoria.

A falta de clareza de Walton, Gordon e Prakken quanto ao ponto de vista da análise é refletida na terminologia aceita e rejeitada, que evoca a ideia de que a premissa foi aceita ou rejeitada pelas partes no diálogo. Assim, para eliminarmos dúvidas, preferimos empregar a terminologia verdadeira e falsa, pois ela desvincula o status da premissa da opinião das partes e ressalta o ponto de vista do analista.

De outro lado, a distinção entre premissas enunciadas e premissas questionadas marca a diferença entre fazer uma asserção sobre uma premissa e questionar uma premissa e, portanto, entre se colocar pró ou contra uma premissa. O conceito que utilizamos de "premissa neutra" diz apenas que a premissa não é tida como verdadeira nem como falsa.

Apesar da distinção entre fazer uma asserção e fazer um questionamento ser importante, entendemos que ela não deva ser considerada como um status da premissa, ou, pelo menos, não deva pertencer ao mesmo rol de classificação em que se enquadram as

${ }^{21}$ GORDON, PRAKKEN, WALTON, 2007, p.15-16. 
premissas verdadeiras e as premissas falsas. Do nosso ponto de vista, o status deve servir para apontar com precisão, em qualquer momento de um diálogo, se houver, a tese vencedora e os argumentos que a sustentam, bem como os argumentos que a atacam, e as premissas que já foram sustentadas com sucesso, e as que não foram. A classificação mais simples é a de que existem premissas verdadeiras, falsas e neutras. Dizer que uma premissa foi enunciada não nos diz nada disso e não ajuda com relação aos tipos de premissas. Tanto uma presunção relativa, quanto uma premissa ordinária ou uma exceção podem ser enunciadas. Cada uma delas terá, pela característica do tipo de premissa, um valor de verdade prima facie distinto, que não será bem representado se identificarmos seu status como premissa enunciada. O mesmo vale para o questionamento. Questionar uma suposição a torna falsa, mas questionar uma presunção relativa, por exemplo, não altera se ela é verdadeira ou falsa.

Assim, para que haja uma relação útil entre a classificação de tipos de premissas de acordo com o ônus da prova e o de status das premissas, entendemos que o status deva ser classificado em premissas verdadeiras, falsas e neutras. A informação de que houve uma asserção ou questionamento é importante, mas deve ser considerada de outra forma.

Em terceiro lugar, vale mencionar que a presunção relativa é o oposto de uma exceção. A presunção relativa é verdadeira até que se prove o contrário, e a exceção é falsa até que se prove o contrário. Em um sistema formal que busque representar um argumento, é suficiente apenas um dos dois conceitos, utilizando-se a negação da proposição para chegar ao outro tipo. Por exemplo, por sabermos que Sócrates torceu para o Corinthians em determinado jogo, presumimos que ele seja corinthiano. Nesse caso, a proposição "Sócrates é corinthiano" entra no diálogo como uma presunção relativa. Assim, esta afirmação será tornada falsa apenas na presença de provas em contrário, por exemplo, que Sócrates torcia para o Corinthians apenas para que o time dele não caísse para a segunda divisão. Se negarmos a premissa dizendo que "é falso que Sócrates, por ter torcido para o Corinthians em um determinado jogo, é corinthiano", esta afirmação se comportará como uma exceção, sendo falsa até que se prove o contrário. 
Para alguém que queira explicar, apresentar e classificar a argumentação real, é muito estranho e difícil visualizar as presunções relativas como a negação das exceções e vice-versa. Além disso, pelo menos no Direito Brasileiro, o conceito de presunção relativa é bastante conhecido e utilizado deste modo. A palavra presunção no cotidiano também é utilizada em sentido parecido e não como o contrário de uma exceção. Assim, nesse caso justifica-se a apresentação de dois conceitos, de acordo com o uso.

Em quarto lugar, pode haver quem defenda que em um sistema formal a presunção absoluta poderia ser simplesmente representada como uma premissa verdadeira já que ela é verdadeira em qualquer caso. Entendemos que há um problema em realizar essa identificação entre premissa verdadeira e presunção absoluta. As premissas ordinárias, as exceções e as outras também podem ser verdadeiras ou não. Dizer simplesmente que a premissa é verdadeira deixa de identificar a peculiaridade da presunção absoluta. Quando uma premissa é classificada como uma presunção absoluta pelo analista, ele identifica a razão pela qual entende que eventuais argumentos em contrário não devem ser aceitos para alterar o status da premissa. Além disso, o analista aponta que o ataque a ser realizado para derrubar aquela premissa deve ser à sua classificação como presunção absoluta. No Direito Brasileiro, por exemplo, é comum discutir se uma presunção é absoluta ou relativa.

Em quinto lugar, vale ressaltar que a classificação de premissas realizada nessa seção diz respeito ao ônus da prova associado a cada uma delas. Na primeira seção desse capítulo já foi realizada outra classificação de premissas, em afirmações particulares, existenciais e generalizações. Trata-se de duas classificações distintas com finalidades distintas, ainda que ambas sejam sobre premissas.

Além dos tipos de premissas e dos status das premissas, ainda existe outra questão importante sobre o ônus da prova: trata-se dos standards de prova. Para esclarecer o significado de standards de prova retomemos o exemplo do homicídio de Tostão por Sócrates. 
Para provar que Sócrates é o autor do homicídio de Tostão, a acusação pode alegar, dentre outras coisas, que Sócrates se beneficiaria com a morte de Tostão. Sócrates estaria interessado em tomar o lugar de Tostão na Seleção Brasileira de Futebol ${ }^{22}$. Não há dúvidas de que o benefício existe, mas a pergunta é: isso seria motivo suficiente para levar Sócrates a cometer um homicídio?

No fundo, questiona-se a força dessa prova, a capacidade que ela tem de provar o que pretende. A força necessária para que uma premissa seja provada é o standard de prova. A avaliação da força das provas também é importante para a satisfação do ônus da prova. Assim, para haver prova positiva ou negativa das premissas, conforme a tabela apresentada acima, necessário que seja satisfeito o standard de prova estabelecido.

Por exemplo, em um processo penal, o júri deve condenar o acusado apenas se estiver convicto de sua culpa para além de qualquer dúvida razoável (beyond reasonable $d o u b t$ ). Em processos de natureza cível ou administrativa, ou dependendo do momento em que esteja o processo, podem ser utilizados outros standards, como a preponderância de evidências (preponderance of evidence), a existência de evidências claras e convincentes (clear and convincing evidence), ou simplesmente uma centelha de evidência (scintilla of evidence $)^{23}$.

Outro conceito importante é o dos meios de prova. Como o próprio nome diz, tratase dos modos pelos quais alguém pode provar alguma coisa. Testemunhas, documentos, fotografias, vídeos, são todos meios de prova.

\footnotetext{
${ }^{22}$ Para os conhecedores de futebol, estamos cientes de que Tostão real jogou na Seleção Brasileira entre 1966 e 1972 e Sócrates de verdade entre 1978 e 1986. Mas não estamos tratando dos jogadores de verdade. Qualquer semelhança com a realidade é mera coincidência.

${ }^{23}$ Os standards de prova aqui citados são discutidos por Gordon e Walton, que fazem um esforço de formalização, a fim de torná-los mais precisos e úteis para uma teoria geral da argumentação e para utilização em modelos computacionais. GORDON, Thomas F.; WALTON, Douglas. A formal model of legal proofs standard and burdens. in EEMERAN, Frans H. Van; GARSSEN, B.; BLAIR; J. A. \& MITCHELL, G. R. (Eds.), 7th Conference on Argumentation of the International Society for the Study of Argumentation (ISSA 2010). Amsterdam: Sic Sac, 2011, p. 644-655.
} 
Por vezes, principalmente no Direito, os standards de prova estão associados aos meios de prova. Assim, há provas que só podem ser feitas por meios específicos e provas que não podem ser realizadas por alguns meios. Por exemplo, para requerer judicialmente o inventário, é necessária a certidão de óbito da pessoa que morreu e deixou a herança (Art. 987, Parágrafo Único do CPC).

Para encerrar a discussão dessa seção sobre ônus da prova e conceitos associados, devem ser realizadas ainda duas observações. Quanto à classificação das premissas, vale destacar que ela pode ser objeto de debate dentro do diálogo. Por exemplo, pode haver dúvida e discussão se uma premissa trazida ao diálogo deve ser tratada como uma premissa ordinária ou uma presunção relativa. Como dito, em Direito, uma discussão comum é sobre algumas premissas extraídas da lei; se elas devem ser consideradas presunções relativas ou presunções absolutas.

Por fim, os exemplos discutidos e a própria expressão ‘ônus da prova' levam a pensar que apenas situações de fato, como Sócrates matou Tostão ou a Terra gira em torno do Sol, sejam afetadas pelo ônus da prova. No entanto, situações de outro tipo, como a melhor interpretação de um dispositivo legal, também terão de ser objeto de prova nesse sentido. Mesmo que ela se dê somente via argumentação, sem a necessidade de trazer algum elemento material por um meio de prova, como um documento ou testemunha. Todas as premissas possuem algum ônus da prova associado. No Capítulo 2 será importante ter isso em mente ao discutirmos a distinção entre questões de fato e questões de direito.

\section{I.1.D Ataques}

O que dá sentido aos diálogos argumentativos é a existência de pelo menos duas posições opostas sobre algum problema. A argumentação será utilizada para resolver a questão dada e se chegar à melhor resposta. Assim, em um diálogo haverá argumentação nos dois sentidos, e uma parte atacará os argumentos da outra parte. Aqui as coisas se tornam mais difíceis e, ao mesmo tempo, mais interessantes e divertidas. 
Existem várias maneiras de atacar a argumentação da outra parte no diálogo. Fundamental que se discuta quais são e como operam. Para isso, vamos abusar de nosso herói mais uma vez. Sócrates vai ao shopping com Tostão para almoçar. Ao terminarem de comer, surge a dúvida: devem deixar a bandeja na mesa para que a funcionária do shopping a retire ou devem levar a bandeja? Sócrates argumenta:

(Premissa 1) Deixar a bandeja na mesa gera trabalho.

(Premissa 2) O trabalho para retirar a bandeja da mesa gera empregos.

(Conclusão) Devemos deixar a bandeja na mesa.

De acordo com Walton, Reed e Macagno há quatro maneiras de atacar esse $\operatorname{argumento}^{24}$. A primeira é atacar as premissas. Caso se mostre que qualquer uma delas é falsa, não haverá suporte à conclusão. A segunda é atacar o link inferencial entre as premissas e a conclusão, ou seja, argumentar que a conclusão não se segue das premissas expostas. A terceira é atacar diretamente a conclusão por meio de um argumento que defenda a conclusão oposta, no caso, de que não devemos deixar a bandeja na mesa. Vale lembrar que para os argumentos dedutivos isso não será possível, pois a conclusão é necessariamente verdadeira. Por fim, pode-se realizar um ataque dizendo que o standard de prova necessário para justificar a conclusão não foi atingido.

Assim, Tostão pode atacar o argumento de Sócrates de várias maneiras. Vejamos como Tostão reage.

(Ataque 1) O trabalho para retirar a bandeja da mesa não gera empregos. $O$ shopping apenas aproveita os empregados que ele já possui e lhes dá a função extra de recolher as bandejas. $O$ único efeito é aumentar a quantidade de trabalho dos empregados já existentes. (Ataque às premissas)

\footnotetext{
${ }^{24}$ No Capítulo 7 do livro Argumentation Schemes os autores fazem uma extensa discussão sobre ataques, empreendendo uma revisão da literatura e enfrentando o pântano terminológico (teminological swamp, p. 221) em que se encontra o tema. Uma das principais contribuições é a revisão da hipótese de que haveria três maneiras (three-way hypothesis) de se atacar um argumento. O esforço de explicar claramente, padronizar a terminologia e justificar as suas escolhas frente à literatura é importante, mas não será reproduzido aqui. Faremos nossa discussão sobre o tema a partir das conclusões e comentários dos autores. As quatro maneiras e o sumário de algumas conclusões podem ser encontrados na página 258. WALTON; REED; MAGAGNO. 2008, Cap. 7
} 
(Ataque 2) Das premissas não se segue a conclusão. Ainda que deixar a bandeja na mesa gerasse empregos, não entendo porque gerar empregos justificaria deixar a bandeja na mesa. (Ataque ao link inferencial)

(Ataque 3) Deixar a bandeja na mesa atrapalha as próximas pessoas que pretendem sentar e estão carregando as suas próprias bandejas. Atrapalhar os outros é algo ruim e deve ser evitado. (Ataque à conclusão)

Com esses ataques, Tostão empregou três dos quatro tipos de ataque ao argumento de Sócrates. Agora é a vez de Sócrates se defender.

(Contra-ataque 1) Em algum ponto a quantidade de trabalho criada não poderá ser suportada pelos empregados existentes, o que obrigará o shopping a contratar novos empregados. Se todos deixarem a bandeja na mesa isso certamente acontecerá.

(Contra-ataque 2) Eu assumi implicitamente que gerar empregos é uma boa coisa. Se deixar a bandeja na mesa gera empregos e gerar empregos é uma boa coisa, então devemos deixar a bandeja na mesa.

(Contra-ataque 3) Você tem razão ao dizer que deixar a bandeja na mesa atrapalha as pessoas e atrapalhar as pessoas é uma coisa ruim. No entanto, atrapalhar as pessoas é um preço pequeno a se pagar pela geração de empregos, algo muito mais valioso.

A discussão entre Sócrates e Tostão se estende ainda por muito tempo. O que talvez tenha servido de motivo para Sócrates matar Tostão na seção sobre ônus da prova. Pelo bem da nossa paciência, podemos parar a reprodução da discussão por aqui.

O primeiro contra-ataque de Sócrates defende que a sua premissa é verdadeira, ainda que deixe transparecer que a relação entre deixar uma bandeja na mesa e gerar um emprego não seja tão automática. São necessárias muitas bandejas e muito trabalho para que se justifique a geração de um emprego.

O segundo contra-ataque de Sócrates explicita uma premissa não enunciada em sua primeira formulação do argumento. Reformulado, o argumento fica como segue: 
(Premissa 1) Deixar a bandeja na mesa gera trabalho.

(Premissa 2) O trabalho para retirar a bandeja da mesa gera empregos.

(Premissa 3) Gerar empregos é uma boa coisa.

(Conclusão) Devemos deixar a bandeja na mesa.

Apesar da Premissa 3 parecer algo óbvio, Tostão tinha razão em seu segundo ataque. Sem a Premissa 3 o conjunto de premissas não dá suporte à conclusão. Fica faltando alguma coisa. E apesar de parecer óbvia, a Premissa 3 também pode sofrer ataques. Tostão poderia dizer que gerar empregos aumenta os custos do shopping e que esses custos seriam repassados a todas as lojas e consumidores. O malefício causado seria maior que o benefício.

O contra-ataque 3 de Sócrates compara os malefícios gerados por atrapalhar as pessoas com os benefícios da geração de empregos. Ou seja, coloca a força dos argumentos numa balança. Desse modo, Sócrates diz que a prova mais forte é a sua, o que justificaria a tese de que devemos deixar a bandeja na mesa. Assim, este contra- ataque é do quarto tipo mencionado acima, se referindo aos standards de prova. No fundo, Sócrates diz que o argumento de Tostão não satisfaz o standard mais alto do argumento da geração de empregos, sendo incapaz de infirmar a conclusão de que devemos deixar a bandeja na mesa.

Para que o argumento de Sócrates justifique a conclusão, assume-se que basta um argumento ser mais forte que o outro para prevalecer e justificar a conclusão. Trata-se do standard de provas da preponderância de evidências. Tanto a avaliação de Sócrates quanto a ideia de que no caso o standard adequado a ser utilizado é o de preponderância de evidências podem ser objeto de debate.

Além das quatro maneiras de atacar um argumento é importante ainda tratar dos conceitos de réplica (rebuttal) e refutação (refutation) (AS, p.258). Quando um argumento é oposto a um argumento anterior, temos uma réplica. Quando a réplica obtém sucesso e derruba (knock down) o argumento original, temos uma refutação. A réplica pode ser construída como qualquer um dos quatro tipos de ataque mencionados anteriormente. 
Com os conceitos básicos apresentados de acordo com Walton, Reed e Macagno, podemos discutir algumas dificuldades no entendimento dos ataques. Os autores dedicam atenção especial ao segundo tipo de ataque, o que é dirigido ao link inferencial entre as premissas e a conclusão. O que significa mais precisamente esse ataque? Como ele se distingue do ataque às premissas e do ataque à conclusão?

A explicação de Walton, Reed e Macagno é a de que na verdade o ataque ao link inferencial se dá por meio de questões críticas (critical questions) de um esquema de argumento (argument scheme), que mostram que o esquema é inaplicável a um caso concreto, a menos que sejam respondidas satisfatoriamente (AS, p.257/258). Esses conceitos serão apresentados apenas mais adiante nesse Capítulo. Por ora, vamos examinar o ataque ao link inferencial de outro modo.

O link inferencial é a estrutura que conecta as premissas à conclusão, dando-lhe suporte. Como vimos, a estrutura inferencial de um argumento e, portanto, o seu link, pode ser de três tipos: dedutivo, indutivo e derrotável. Como pode se dar um ataque a esse link? Acreditamos que de duas maneiras. Em primeiro lugar, pode se dizer que não há link porque o argumento está incompleto, faltando premissas que permitam o suporte à conclusão. Esse é justamente o caso do exemplo acima, em que Tostão criticou o argumento de Sócrates, por faltar a premissa que dizia que gerar empregos era uma boa coisa. Não se pode considerar esse tipo de ataque um ataque às premissas, pois o que se diz é que não há premissa. Também não é um ataque direto à conclusão e nem trata dos standards de prova.

Em segundo lugar, podemos considerar um ataque ao link inferencial aquele que apresenta uma exceção ao argumento por meio da adição de uma nova premissa. Retomemos o seguinte exemplo: 
(Premissa 1) Os corinthianos geralmente assistem a um jogo no Pacaembu pelo menos uma vez na vida.

(Premissa 2) Sócrates é corinthiano.

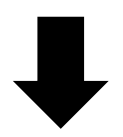

(Conclusão) Sócrates assistiu a um jogo no Pacaembu pelo menos uma vez na vida.

Caso adicionemos a informação de que Sócrates é estrangeiro e nunca viajou ao Brasil a conclusão se tornará falsa. A generalização é derrotada no caso concreto. O link que antes existia entre as premissas e a conclusão é cortado pela exceção.

(Premissa 1) Os corinthianos geralmente assistem a um jogo no Pacaembu pelo menos uma vez na vida.

(Premissa 2) Sócrates é corinthiano.

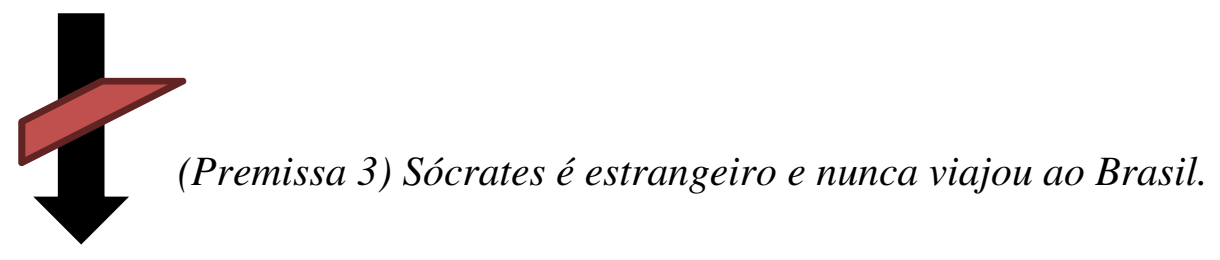

(Conclusão) Sócrates assistiu a um jogo no Pacaembu pelo menos uma vez na vida. (Nova Conclusão) Sócrates não assistiu a um jogo no Pacaembu pelo menos uma vez na vida.

A interpretação de que haveria um ataque ao link inferencial nesse caso é criticada por Walton, Reed e Macagno (AS, p.256/257). Segundo os autores, não cabe falar em ataque ao link inferencial porque o condicional permanece verdadeiro. Deve-se falar apenas em inaplicabilidade (default) no caso concreto.

(Condicional) Se os corinthianos geralmente assistem a um jogo no Pacaembu pelo menos uma vez na vida e Sócrates é corinthiano, então Sócrates (plausivelmente) assistiu a um jogo no Pacaembu pelo menos uma vez na vida. 
Contudo, se estamos diante de um diálogo real e concreto nos parece que a melhor interpretação é a de que a argumentação não seja um ataque a um condicional sem implicação existencial. Pelo contrário, em um diálogo real e concreto não apenas a questão sintática está em jogo. A pragmática é fundamental. Ou seja, quem utilizar esse argumento em um diálogo real estará fazendo uma afirmação sobre o mundo. A parte no diálogo não conclui que "Sócrates (plausivelmente) assistiu a um jogo no Pacaembu". A parte conclui, plausivelmente, que "Sócrates assistiu a um jogo no Pacaembu". A diferença é sutil, mas existe. Ou seja, há conclusões argumentativas com e sem implicação pragmática.

(Premissa 1) Os corinthianos geralmente assistem a um jogo no Pacaembu pelo menos uma vez na vida.

(Premissa 2) Sócrates é corinthiano.

(Premissa 3) Sócrates é estrangeiro e nunca viajou ao Brasil.

(Conclusão com implicação pragmática) Sócrates assistiu a um jogo no Pacaembu pelo menos uma vez na vida.

(Conclusão sem implicação pragmática) Sócrates plausivelmente assistiu a um jogo no Pacaembu pelo menos uma vez na vida.

(Nova Conclusão) Sócrates não assistiu a um jogo no Pacaembu pelo menos uma vez na vida.

A ligação entre a Premissa 1 e a Premissa 2 à conclusão sem implicação pragmática permanece mesmo após a introdução da exceção. Como ressaltam Walton, Reed e Macagno, o condicional permanece verdadeiro, mas não é aplicável ao caso concreto. Pode-se dizer que, tendo por base as Premissas 1 e 2, a conclusão de que Sócrates plausivelmente assistiu a um jogo no Pacaembu pelo menos uma vez na vida é fruto de um raciocínio logicamente correto, ainda que no caso concreto seja errada. Tendo apenas essas informações disponíveis, esse é o melhor raciocínio que alguém pode empreender. A proposição "Sócrates plausivelmente assistiu a um jogo no Pacaembu pelo menos uma vez na vida” é verdadeira, tendo Sócrates assistido ou não a um jogo naquele estádio.

No entanto, se da Premissa 1 e da Premissa 2 queremos concluir que no caso real e concreto Sócrates efetivamente assistiu a um jogo no Pacaembu pelo menos uma vez na vida, estamos querendo concluir mais do que no parágrafo anterior. Nessa nova hipótese o 
nosso raciocínio possui uma implicação pragmática. Trata-se de uma aposta de que o argumento derrotável é verdadeiro. A exceção posta pela Premissa 3 torna essa conclusão com implicação pragmática falsa, e verdadeira a Nova Conclusão de que Sócrates não assistiu a um jogo no Pacaembu pelo menos uma vez na vida.

Como observado ao tratar dos argumentos derrotáveis no começo deste Capítulo, a Premissa 3, ao ser adicionada, não altera o valor de verdade das premissas anteriores. Não é, portanto, um ataque às premissas. Também não se trata de standards de prova. Resta a dúvida se tal ataque não poderia ser considerado um tipo de ataque especial à conclusão ao invés de um ataque ao link inferencial. Entendemos que não.

Os ataques à conclusão propriamente ditos se dão pela construção de um segundo argumento paralelo que, sem alterar o suporte dado pelo primeiro argumento à conclusão, fornece suporte para se concluir pela falsidade da conclusão. Do diálogo acima, podemos tomar como exemplo o argumento de Sócrates de que deixar a bandeja na mesa gera empregos e por isso é uma boa coisa que devemos fazer. O ataque de Tostão que dizia que deixar a bandeja na mesa era algo ruim porque atrapalhava as outras pessoas é um ataque à conclusão propriamente dito. Sozinho ele não altera o valor de verdade das premissas de Sócrates, nem retira o suporte que as premissas dão à conclusão de Sócrates. Ele ataca apenas a conclusão. A questão, a partir daí, passa a ser qual dos dois argumentos é mais forte e qual é o standard de prova para resolver o problema.

A exceção não procede dessa maneira. Ainda que as premissas permaneçam verdadeiras, o suporte do argumento original não é mais o mesmo. Não se trata simplesmente de um argumento com uma conclusão oposta. A exceção prejudica o argumento original. Esse prejuízo ao suporte, que não se localiza nem no ataque às premissas, nem no ataque à conclusão, pode ser chamado propriamente de um ataque ao link inferencial nos casos em que a exceção combate uma conclusão com implicação pragmática.

E para os casos de exceção que combatem conclusões sem implicação pragmática? Devemos falar apenas em inaplicabilidade no caso concreto, como pretendem Walton, Reed e Macagno? Entendemos que não. Para nós faz sentido terminológico dizer que 
também nesta hipótese há um ataque ao link inferencial, apesar da opinião dos autores. Isso porque com a adição da exceção por meio da Premissa 3 temos um novo conjunto de premissas, e nesse novo conjunto não se pode mais fazer a inferência original de que Sócrates plausivelmente assistiu a um jogo no Pacaembu, a não ser que a Premissa 3 seja ignorada. O condicional que permanece verdadeiro é um condicional que ignora a existência da Premissa 3. Não é mais o melhor argumento que se pode extrair do conjunto de premissas. Dizer simplesmente que o condicional é inaplicável ignora esse déficit de que o argumento ignora as evidências apresentadas e de que a ligação original entre premissas e conclusão não se sustenta mais no novo cenário. Se alguém tem à sua disposição as Premissas 1, 2 e 3, não pode concluir que seja plausível Sócrates ter assistido a um jogo no Pacaembu. Isso está logicamente errado.

Desse modo, ao introduzir uma exceção, a parte no diálogo altera o conjunto de premissas e modifica as possíveis inferências a serem realizadas. Não se trata de um ataque ao valor de verdade das premissas anteriores nem de um problema de standard de prova; tampouco há um ataque à conclusão por um argumento separado. Toda a estrutura de ligação entre premissas e conclusão é prejudicada e não pode mais ser utilizada. Assim, pode-se falar propriamente em um ataque ao link inferencial também nos casos sem implicação pragmática.

A discussão sobre os possíveis ataques ao link inferencial e sobre a viabilidade de se classificar a exceção como um ataque ao link inferencial chama a atenção para um problema com a classificação dos ataques em ataque às premissas, ao link inferencial e à conclusão. Tal classificação pouco nos diz sobre o funcionamento efetivo dos ataques. Por esse motivo tivemos de esclarecer acima que o ataque ao link pode se dar pela incompletude do argumento ou por meio da exceção.

A quarta possibilidade identificada por Walton, Reed e Macagno de ataques baseados nos standards de prova suscita problemas no mesmo sentido. Podemos imaginar ataques com base em standards de prova dirigidos tanto à conclusão quanto às premissas de um argumento. A dúvida que se coloca é se, por isso, tal ataque não deveria ser eventualmente considerado um ataque às premissas ou à conclusão. 
O problema surge porque a classificação dos tipos de ataques em ataques às premissas, ao link inferencial e à conclusão obedece a critério diferente do da classificação que enxerga o ataque baseado no standard de prova como um tipo de ataque. As três primeiras classes se relacionam à localização dos ataques na estrutura do argumento, enquanto que a última tem a ver com o funcionamento do ataque. Assim, a fim de eliminar confusões e esclarecer melhor a utilização dos ataques, propomos aqui uma dupla classificação dos ataques: quanto à sua localização na estrutura do argumento e quanto ao seu funcionamento.

Quanto à localização na estrutura do argumento, os ataques podem ser de três tipos: (a) ataques às premissas; (b) ataques ao link inferencial; e (c) ataques à conclusão. Devemos notar que se há um ataque às premissas de um argumento, pode ser que essas premissas também sejam a conclusão de outro argumento ou de toda uma argumentação. A argumentação constitui uma espécie de encadeamento de argumentos. O critério, no entanto, é simplesmente o da localização do ataque na estrutura do argumento específico que está sendo analisado. Assim, a classificação em ataque às premissas e ataque à conclusão será sempre relativa ao argumento que está sendo considerado na análise.

Quanto ao funcionamento, divisamos cinco tipos básicos de ataques: (1) argumento contrário; (2) exceção; (3) ônus da prova e standard de prova; (4) questionamento; (5) incompletude do argumento atacado.

O argumento contrário é um argumento cuja conclusão é oposta à proposição que se quer atacar, seja ela uma premissa ou uma conclusão. Por exemplo, o ataque de Tostão, que disse que deixar as bandejas atrapalha as pessoas, o que é algo ruim e deve ser evitado. A conclusão desse argumento é de que não se deve deixar a bandeja na mesa, ou seja, o oposto do que defende Sócrates, de que a bandeja deve, sim, ser deixada na mesa.

A exceção é a adição de uma nova premissa que sem alterar o valor de verdade (status) das premissas anteriores retira o suporte da conclusão. Não se deve confundir a exceção como ataque com a exceção como tipo de premissa quanto ao ônus da prova. São coisas diferentes, apesar das premissas adicionadas pelas exceções como ataques geralmente terem o seu ônus da prova do tipo exceção. 
O ônus da prova e standard de prova dizem respeito aos ataques que se baseiam em dizer que o argumento não cumpre com seu ônus probatório. Por exemplo, o contra -ataque 3 de Sócrates, acima, que disse que o fato de deixar a bandeja na mesa atrapalha as pessoas não é tão forte quanto o argumento contrário baseado na geração de empregos.

O questionamento é o ato puro e simples de por em questão a veracidade de uma premissa. Como há premissas que são consideradas verdadeiras até o momento em que são questionadas (as suposições), o simples questionamento já é um ataque que pode ser suficientemente forte para alterar o status de uma premissa. Em contextos jurídicos nos quais se discutem direitos patrimoniais disponíveis, o questionamento é especialmente importante. Isso porque se uma parte não questiona uma premissa fática por ocasião da sua contestação, tal fato será tido como verdadeiro no processo judicial.

Por fim, é possível atacar um argumento simplesmente expondo que ele é incompleto, e, por isso, as conclusões não se seguem das premissas. Por exemplo, o Ataque 2 de Tostão, no diálogo acima, que levou Sócrates a adicionar uma premissa em seu argumento. Às vezes ao se dizer que um argumento é incompleto pode ser atribuída uma premissa à outra parte no diálogo, para então ser construído um argumento oposto. A atribuição dessa premissa pode ser objeto de debate e não precisa, necessariamente, ser realizada.

É possível cruzar essas classificações para que possamos saber a que partes da estrutura do argumento se dirigem os diferentes tipos de ataque. O argumento contrário pode se dirigir tanto às premissas quanto à conclusão. Como discutido em maiores detalhes acima, a exceção e a incompletude caracterizam-se como ataques ao link inferencial. $\mathrm{O}$ questionamento pode ser direcionado às premissas ou às conclusões (ressaltando-se que a tese em debate, que também é uma conclusão, já começa o diálogo sendo questionada). Por fim, os ataques baseados em ônus da prova ou standards de prova podem ser direcionados às premissas ou às conclusões. 
Há alguns ataques especiais que merecem destaque pelo fato de serem vistos com frequência na prática e poderem ser entendidos como combinações complexas dos tipos básicos. Por exemplo, existe a possibilidade de se atacar o tipo de premissa utilizado (afirmação particular, afirmação existencial, generalização universal, generalização indutiva, generalização derrotável). Não é raro ouvir um diálogo mais ou menos nos termos deste de Sócrates e Tostão:

Sócrates: É claro que ele é corrupto, ele é cartola! Todos os cartolas são corruptos.

Tostão: Todos? Você está sendo exagerado, Sócrates. Eu mesmo conheço alguns cartolas e sei que eles são gente honesta. O máximo que você pode dizer, talvez, é que geralmente os cartolas são corruptos, mas todos não.

Sócrates se valeu de uma generalização universal e Tostão a questionou, defendendo que ela deveria ser substituída por uma generalização derrotável. Ou seja, o ataque à premissa dizia que a generalização universal utilizada por Sócrates era falsa, mas fez mais do que isso. $\mathrm{O}$ ataque substituiu a premissa original por outra de conteúdo bastante similar, mudando apenas o seu alcance, de universal para derrotável. Esse tipo de ataque em que há substituição de premissas é bastante comum em diálogos reais.

Um tipo de ataque especial parecido com o do exemplo anterior é aquele que discute a classificação da premissa quanto ao ônus da prova, em ordinária, suposição, exceção, presunção relativa e presunção absoluta. Veja-se o exemplo acima reformulado.

Sócrates: É claro que ele é corrupto, ele é cartola!

Tostão: Você está sendo exagerado, Sócrates. Não se pode presumir do fato do sujeito ser cartola, que ele seja corrupto. Aliás, não se pode presumir de nenhuma maneira, isso é mera suposição!

No novo exemplo Sócrates não declinou mais a premissa na qual se baseou para dizer que ser cartola significa ser corrupto. Pode ser uma generalização universal, indutiva ou derrotável. Mas é possível atacar o argumento sem atacar uma premissa que não se sabe qual é, e sem atribuir qualquer premissa à outra parte, como fez Tostão. Ele dá a entender 
que Sócrates fez de sua afirmação uma presunção absoluta e responde dizendo que não é possível presumir nem absolutamente, nem relativamente esse tipo de coisa. Trata-se de mera suposição, que não se sustenta mediante simples questionamento.

No quadro abaixo realizamos o cruzamento das duas classificações acima e adicionamos ainda colunas que tratam da possibilidade de realizar cada tipo de ataque a cada parte do argumento, para cada tipo de argumento (dedutivo, indutivo ou derrotável).

\begin{tabular}{|c|l|c|c|c|}
\hline Estrutura & \multicolumn{1}{|c|}{ Funcionamento } & Dedutivo & Indutivo & Derrotável \\
\hline \multirow{3}{*}{ Premissas } & Argumento contrário & Sim & Sim & Sim \\
\cline { 2 - 5 } & Onus da Prova & Sim & Sim & Sim \\
\cline { 2 - 5 } & Questionamento & Sim & Sim & Sim \\
\hline \multirow{3}{*}{ Link inferencial } & Incompletude & Sim & Sim & Sim \\
\cline { 2 - 5 } & Exceção & Não & Sim & Sim \\
\hline \multirow{3}{*}{ Conclusão } & Argumento contrário & Não & Sim & Sim \\
\cline { 2 - 5 } & Onus da Prova & Não & Sim & Sim \\
\cline { 2 - 5 } & Questionamento & Não & Sim & Sim \\
\hline
\end{tabular}

\section{I.1.E Estágios do Diálogo e Tipos de Diálogo}

Como havíamos mencionado no começo deste Capítulo, os argumentos são estruturados em conjunto de modo a formar uma argumentação que ganha sentido dentro de um diálogo no qual há uma questão a ser resolvida. Nesta seção exploraremos conceitos e distinções que auxiliam a caracterizar melhor o diálogo, classificando seus momentos e seus tipos.

A questão a ser resolvida pode ser objeto de uma disputa (dispute) ou de um dissenso (dissent). Quando um dos participantes possui uma tese contrária à do outro haverá uma disputa, e quando um dos participantes apenas duvida da tese do outro, sem defender uma tese contrária, haverá um dissenso. (FCA, p.36) 
Segundo Walton, a disputa ou o dissenso podem representar um desacordo sobre fatos (factual disagreement) ou um desacordo sobre adotar uma ação ou tipo de ação ser uma boa política ou não (whether some action or kind of action is a good policy or not). Ambos os tipos de proposição podem ser classificadas em verdadeiras ou falsas (FCA, p.174/175). Chamaremos desacordo fático ou de fato o do primeiro tipo, e normativo ou de direito o do segundo tipo. Apesar de Walton não dar muita atenção a essa distinção, entendemos que ela é importante para discussões jurídicas. Ela será retomada no Capítulo 2, ao tratarmos da argumentação jurídica.

Os diálogos possuem idealmente quatro diferentes estágios (stages), nos quais se coloca o problema e se desenvolve a argumentação. A relevância (ver próxima seção) de um argumento, proposição ou questão será julgada de maneira diferente conforme o estágio do diálogo. (FCA, p.184)

(1) Confrontação (confrontation) - Formula-se a tese de uma das partes e a natureza da oposição da outra parte (disputa ou dissenso). A questão a ser resolvida pelo diálogo é determinada por ambas as partes.

(2) Abertura (opening) - As partes decidem começar a discussão e seguir as regras apropriadas ao tipo de diálogo estabelecido.

(3) Argumentação (argumentation) - Cada parte defende seu ponto de vista e questiona e critica o ponto de vista da outra parte.

(4) Fechamento (closing) - A discussão termina e se uma das partes atinge seu objetivo a outra deve aceitar o resultado (the other side must concede).

Além da distinção básica entre disputa e dissenso, os diálogos podem ser classificados em tipos, conforme suas características e propriedades. De acordo com Walton, há seis tipos básicos de diálogo, cada qual com regras diferentes a serem seguidas para que ele possa se tornar um ambiente favorável ao desenvolvimento da argumentação. 
Cada tipo de diálogo pressupõe um quadro conversacional (conversational framework), no qual a argumentação (reasoning) é utilizada para algum propósito específico. (FCA, p. 172 e p.183/184)

O diálogo de persuasão (persuasion dialogue) apresenta participantes sustentando pontos de vista opostos em relação a uma questão central, um tentando persuadir o outro a aceitar o seu ponto de vista. Caracteriza-se por um misto de oposição (em relação ao ponto de vista) e colaboração (em relação ao objetivo do diálogo, que é solucionar o problema central). (FCA, p.173/174)

A característica mais importante de um diálogo de persuasão é que ambos os participantes tentam persuadir o outro de que sua tese é verdadeira (no caso da disputa). Essa persuasão não é psicológica, mas racional (rational persuasion). Isso significa que: (a) o proponente (proponent) tenta fazer o respondente (respondent) aceitar a conclusão, utilizando premissas que o respondente já aceita ou pode ser persuadido a aceitar, usando outros argumentos; (b) o argumento utilizado é estruturalmente correto, seja como uma inferência dedutiva, indutiva ou derrotável. (FCA, p.175)

Se o proponente utiliza um argumento com sucesso nos moldes estabelecidos acima, o respondente é obrigado a aceitar a conclusão. A razão para isso é que os participantes de um diálogo de persuasão devem respeitar um argumento racional (rational argument). Isso faz parte do acordo que eles estabelecem ao se engajarem nesse tipo de diálogo. Caso não seja aceita a conclusão, o participante sai do diálogo de persuasão. (FCA, p.175)

Há um tipo especial de diálogo de persuasão, denominado discussão crítica (critical discussion), em que o objetivo do diálogo é resolver o problema central provando que o ponto de vista de uma parte foi defendido com sucesso, enquanto o da outra não. Nesse tipo de diálogo deve haver um vencedor e um perdedor, ou o diálogo não obtém sucesso. Em outros tipos de diálogo de persuasão, contudo, não precisa haver necessariamente vencedores e perdedores. O fato do diálogo aumentar o conhecimento do assunto pela exposição e crítica de argumentos e falácias já é valioso. (FCA, p.175/176) 
Além do diálogo de persuasão (I), para Walton há cinco outros tipos básicos de diálogo. A seguir explicaremos brevemente cada um dos tipos identificando: seu (a) tipo de problema/questão subjacente; suas (b) características principais de funcionamento; e sua (c) tendência colaborativa ou adversarial, se houver.

(II) Investigação (inquiry) (FCA, p.184/186)

A questão a ser resolvida (irresolução / unsettledness) é se existe prova decisiva da veracidade ou falsidade de uma proposição. Após a coleta de evidências, mesmo que não seja possível provar nem refutar a proposição, o resultado ainda é útil. Ele mostra que não se pode aceitar de plano que a proposição seja verdadeira ou que ela seja falsa.

A investigação é um quadro argumentativo (framework of argument) altamente colaborativo, em que padrões elevados (high standards) de prova são adotados. Primeiramente, são colhidos e organizados todos os dados relevantes. Quando há acordo de que não há mais evidências a serem colhidas, inicia-se o estágio de argumentação. $\mathrm{O}$ método da investigação consiste em aceitar como premissas verdadeiras apenas aquelas suportadas por evidências muito fortes. Isso é importante para que no futuro não seja necessária a retração das premissas nem a construção de uma nova linha de raciocínio com base em novas premissas.

A investigação é frequentemente associada à filosofia do fundacionalismo, que compara o raciocínio com uma construção que deve ser erguida sobre fundações firmemente estabelecidas. É frequentemente associada à ciência, mas não é um bom modelo para descrever a ciência em alguns estágios iniciais de desenvolvimento, especialmente na formulação de hipóteses.

(III) Negociação (negotiation) (p.186/187)

A questão a ser resolvida é um conflito de interesses. Nesse tipo de diálogo problemas sobre a verdade ou a falsidade de uma proposição são secundários. O objetivo é conseguir um "bom acordo" ("a good deal"), isto é, um acordo que ambas as partes entendam aceitável e que envolva ganhos e perdas para ambas. No tipo específico chamado 
barganha distributiva (distributive bargaining) o jogo é de soma zero, no sentido de que o ganho de uma parte é sempre a perda da outra.

Geralmente é um tipo de diálogo associado a questões financeiras, mas não apenas, podendo também ser usado em relacionamentos pessoais (personalidade e motivações/objetivos). A figura das ameaças é comum nas negociações. Veja-se, por exemplo, as negociações feitas pelos sindicatos, em que há ameaças de greve.

(IV) Busca de Informações (information-seeking) (p.187/188)

A questão a ser resolvida é a falta de informação de uma parte ou, vista de outro modo, a assimetria informacional (imbalance of information) entre duas partes. Ocorre quando uma parte presumidamente possui uma informação de que a outra parte precisa ou quer. O papel de uma parte é transmitir a informação para a outra, que não a possui. Esse tipo de diálogo tende a ser colaborativo e não-adversarial.

Um subtipo especial desse tipo de diálogo é aquele em que uma das partes é especialista em um domínio do conhecimento ou está em melhor posição de saber sobre alguma coisa. Testemunhos jurídicos de especialistas são exemplos desse tipo de diálogo.

(V) Deliberação (deliberation) (p.188/189)

A questão a ser resolvida é uma diferença de opinião sobre a melhor maneira de resolver um problema prático que demande algum tipo de ação. A conclusão esperada do diálogo é a resposta sobre o curso de ação particular que uma pessoa prudente ou sábia (prudent or practically wise) deve escolher.

As partes discutem diferentes soluções para o problema (podem ser uma, duas ou mais), e normalmente os participantes se dividem em facções que representam diferentes pontos de vista e argumentam contra os demais. Além de variar o número de pontos de vista, é possível uma deliberação consigo mesmo e uma deliberação entre um grande número de pessoas. 
Também é característica da deliberação que o conhecimento disponível é insuficiente para determinar claramente a escolha que precisa ser feita. Conhecimento de probabilidades é frequentemente relevante em uma deliberação, mas insuficiente.

O modelo mais simples de deliberação apresenta apenas duas partes e dois pontos de vista opostos sobre a solução de um problema. O caso mais simples é chamado frequentemente de dilema (dilemma) pela filosofia. Ocorre quando há dois cursos de ação possíveis, e há de ser feita uma escolha entre essas duas opções.

(VI) Erístico (eristic) (p.188/189)

O problema a ser resolvido é um antagonismo entre duas partes que têm, cada qual, um rancor (grudge) ou mágoa (grievance) profundos (deeply felt) contra a outra. O diálogo toma a forma de uma discussão (quarrel) em que cada parte ataca a outra por todos os meios possíveis. Os tópicos mudam rapidamente, e um alto grau de irrelevância (irrelevance) é tolerado.

O principal tipo de argumento utilizado é o ad hominem. O objetivo de cada parte no diálogo pode ser descrito como bater ("hitting out") verbalmente no oponente. A discussão tem o valioso benefício de permitir que sentimentos fortes sejam aliviados/expostos (vented). Esse é o tipo de diálogo menos colaborativo e mais adversarial (adversarial) de todos os tipos básicos. No entanto, ainda assim devem ser seguidas regras mínimas, permitindo que as duas partes falem.

O diálogo erístico nos mostra uma atitude de mente fechada de ambos os participantes. Assim, se um diálogo de outro tipo se degenerar para um diálogo erístico há um sério risco de não se avançar no objetivo original e de não se sair mais desse modo. Ele é um risco para os outros tipos de diálogo.

Ao analisar com maior cuidado a caracterização dos diálogos e a classificação proposta por Walton, parece-nos que a distinção entre o diálogo de persuasão e a investigação é de gênero para espécie. O mesmo ocorre com a distinção entre o diálogo de persuasão e a deliberação, sendo o primeiro gênero e o segundo espécie. 
Assim como no diálogo de persuasão, a investigação se desenvolverá baseada em argumentação racional. A diferença no modo de funcionamento parece residir apenas no procedimento de colheita de evidências que cerca a investigação e nos padrões rigorosos de prova utilizados. O tipo de questão colocada também não é diferente; a sua caracterização apenas é diferente em virtude dos altos standards de prova. Para alguns tipos de diálogo de persuasão o aumento do conhecimento é considerado valioso em si, independentemente de haver um resultado conclusivo, como na investigação.

De outro lado, a deliberação tal qual caracterizada por Walton também parece se desenvolver com base na argumentação racional. O fato da questão tratada envolver um curso de ação não impede sua caracterização como um diálogo de persuasão (questão a ser resolvida por argumentação racional). A possibilidade de a deliberação incluir mais de duas pessoas e mais de dois cursos de ação para escolha, tampouco impede sua caracterização como um diálogo de persuasão.

A investigação e a deliberação nos parecem, portanto, caber dentro do conceito mais geral de diálogo de persuasão, sendo que em todos os casos se busca descobrir a melhor resposta sobre a correção de uma proposição ou de um conjunto de proposições, sempre com base na argumentação racional. Apesar de serem considerados subtipos importantes e de merecerem destaque, não nos parece haver critério relevante para considerar a investigação e a deliberação tipos básicos de diálogo.

Feitas essas considerações, elaboramos os quadros abaixo com a classificação dos tipos de diálogo revista, identificadas suas principais características de funcionamento e principais subtipos:

\begin{tabular}{|l|c|c|c|}
\hline \multicolumn{1}{|c|}{ Tipo de Diálogo } & Questão/Problema & Funcionamento & Tendência \\
\hline$\underline{\text { Persuasão }}$ & Melhor resposta & Argumentação racional & $\begin{array}{l}\text { Parte colaborativo } \\
\text { e parte adversarial }\end{array}$ \\
\hline$\underline{\text { Negociacão }}$ & Conflito de interesses & $\begin{array}{c}\text { Busca de acordo, envolvendo } \\
\text { ganhos e perdas para as partes }\end{array}$ & $\begin{array}{c}\text { Parte colaborativo } \\
\text { e parte adversarial }\end{array}$ \\
\hline$\underline{\text { Busca de Informacões }}$ & $\begin{array}{c}\text { Falta/Assimetria de } \\
\text { informação }\end{array}$ & $\begin{array}{c}\text { Perguntas e respostas buscando } \\
\text { compartilhamento de informação }\end{array}$ & Colaborativo \\
\hline
\end{tabular}




\begin{tabular}{|l|l|c|c|}
\hline Erístico & Antagonismo emocional & $\begin{array}{c}\text { Discussão (quarrel), argumento } \\
\text { ad hominem e alívio de } \\
\text { sentimentos }\end{array}$ & Adversarial \\
\hline
\end{tabular}

\begin{tabular}{|l|c|}
\hline \multicolumn{1}{|c|}{ Tipo de Diálogo } & Principais Subtipos \\
\hline$\underline{\text { Persuasão }}$ & Discussão Crítica, Investigação, Deliberação \\
\hline$\underline{\text { Negociaccão }}$ & Barganha Distributiva \\
\hline$\underline{\text { Busca de Informações }}$ & Diálogo com Expert \\
\hline$\underline{\text { Erístico }}$ & - \\
\hline
\end{tabular}

Sobre a classificação dos estágios e dos tipos de diálogo cabem ainda algumas observações importantes. Em um diálogo real os estágios do diálogo podem não estar claramente divididos e podem não seguir a ordem esperada (confrontação, abertura, argumentação e fechamento). Não obstante, a classificação é importante, pois identifica os passos que um diálogo deve seguir para se desenvolver adequadamente.

Do mesmo modo que os estágios não são claros em um diálogo real, pode não ser claro o tipo de diálogo que está acontecendo. É possível ainda que o tipo de diálogo mude ao longo do diálogo real. Essas mudanças podem ser lícitas ou ilícitas. A mudança é lícita se o novo tipo de diálogo contribui de alguma maneira para resolver a questão em debate no diálogo original. Por exemplo, pode haver um diálogo de busca de informações que contribua para solucionar a questão de um diálogo de persuasão. (FCA, p.294/295)

Por fim, vale destacar que para uma teoria da argumentação racional (baseada em premissas aceitas e em argumentos estruturalmente corretos) e, portanto, para fins deste trabalho, o tipo básico de diálogo mais importante é o diálogo de persuasão. A análise a ser realizada no Capítulo 3 pressupõe um diálogo desse tipo. 


\section{I.1.F Relevância}

Seriados e filmes de advogados são realmente instrutivos. Quem já viu as discussões que se passam nos tribunais dos seriados certamente já ouviu alguém dizer: “Objeção, Excelência! Irrelevante!”. Isso geralmente acontece quando, ao examinar uma testemunha, o advogado adversário começa a fazer perguntas que não guardam ou ao menos não parecem guardar relação com o caso concreto em discussão.

Veja-se o exemplo a seguir, retirado do filme Legalmente Loira $(2001)^{25}$. No caso um homem muito rico foi assassinado e a suspeita era sua nova mulher, Brooke Windham, bem mais jovem que o homem. Elle, a personagem principal, está advogando para a suspeita e, neste momento, está examinando a testemunha Chutney Windham, a filha do homem que foi assassinado.

Elle: Sabe, uma garota da minha fraternidade, Tracy Marcinco, fez permanente (no cabelo) uma vez. Nós todas tentamos convencê-la a desistir. Cabelos cacheados não ficavam bem nela. Ela não tinha a sua estrutura corporal, mas, felizmente, no mesmo dia em que ela entrou para o concurso de camiseta molhada da Pheta Delta Phi (a fraternidade), ela foi encharcada dos pés à cabeça.

Promotor Joyce Rafferty: Objeção, por que isso é relevante?

Elle: Eu tenho um ponto. Prometo.

Juíza Marina R. Bickford: Então faça-o.

Elle: Chutney, por que os cachos de Tracy Marcinco foram arruinados quando ela ficou encharcada?

Chutney Windham: Porque eles foram molhados.

Elle: Exatamente. Porque a primeira regra para se manter um permanente é que você está proibida de molhar o seu cabelo por pelo menos 24 horas depois de fazê-lo, sob o risco de desativar o tioglicolato de amônia, não é?

Chutney Windham: Sim.

Elle: E alguém que teve, vamos dizer, 30 permanentes anteriores na sua vida não iria estar plenamente consciente dessa regra? E se você de fato não estava lavando o seu cabelo como eu suspeito, pois os seus cachos permanecem intactos, você não teria ouvido o

${ }^{25}$ Legally Blonde, Dir. Robert Luketic, (2001). 
barulho do tiro? E se você de fato ouviu o barulho do tiro, Brooke Windham não teria tido tempo de esconder a arma antes de você descer as escadas. Isso significa que você teria tido de encontrar Brooke Windham com uma arma nas mãos dela para tornar a sua história plausível, não é verdade?

Chutney Windham: Ela tem a minha idade! Ela te contou isso? Como você se sentiria se seu pai casasse com alguém da sua idade?

Elle: Você, Chutney, por outro lado, teve tempo para esconder a arma depois de atirar no seu pai.

Chutney Windham [em lágrimas]: Não foi minha intenção atirar nele!

O exemplo mostra um caso em que o promotor argui a irrelevância do que a advogada está dizendo. Ou seja, o que ela diz não tem nada a contribuir para a resolução do caso (se Brooke Windham tinha ou não matado o Sr. Windham). Contudo, por meio de um raciocínio pouco convencional, a advogada Elle consegue mostrar que, por conta do permanente, o testemunho de Chutney não era plausível e força a confissão de Chutney, que tinha atirado em seu pai.

O exemplo ajuda a esclarecer o conceito de relevância probatória (probative relevance), que é bastante intuitivo. Um argumento ou proposição é relevante caso sirva para dar suporte ou para atacar em última instância a tese controvertida no diálogo. Caso contrário, o argumento ou proposição é irrelevante. (FCA, p.268)

Assim como os argumentos ou proposições podem ser julgados relevantes ou irrelevantes em relação ao diálogo, as premissas podem ser julgadas relevantes em relação ao argumento. (FCA, p. 269) Por exemplo:

(Premissa 1) Chutney sabia que não se pode lavar o cabelo menos de 24 horas após fazer permanente, sob pena de arruiná-lo.

(Premissa 2) Chutney disse que havia lavado o cabelo menos de 24 horas após fazer um permanente.

(Premissa 3) Chutney gostava de tomar banho aos sábados de manhã.

(Conclusão) A história de Chutney é incoerente. 
Da leitura das Premissas 1, 2 e 3 e da Conclusão pode-se notar que a Premissa 1 e 2 juntas dão suporte à Conclusão. A Premissa 3 não contribui, sendo irrelevante para o argumento. Portanto, uma premissa é relevante para o argumento quando ela contribui para dar suporte à conclusão. Caso contrário, é irrelevante.

A relevância pode não ser clara em determinado momento do diálogo, mas pode se tornar clara depois. Ou seja, o momento em que se encontra o diálogo faz diferença para julgar a relevância. O caso acima de Elle e Chutney mostra exatamente isso. A princípio a discussão sobre o permanente parecia irrelevante, mas se mostrou fundamental para derrubar a plausibilidade do testemunho de Chutney.

Por conta desse fenômeno, estágios iniciais do diálogo tendem a tolerar proposições ou argumentos, ainda que eles não pareçam relevantes, enquanto estágios mais avançados demandarão que a conexão entre a proposição ou argumento e a tese em debate esteja perfeitamente clara e encadeada.

Segundo Walton, além da relevância probatória há outros tipos de relevância. Há a relevância tópica (topical relevance) na hipótese de duas proposições ou dois argumentos tratarem do mesmo assunto (FCA, p.270). A relevância emocional ou psicológica (emotional/psychological relevance) diz respeito à importância subjetiva (para alguém) de uma proposição ou argumento. Por fim, a relevância dialética (dialectical relevance) se refere ao fato de uma proposição ou argumento ser apropriado ou não como parte de um diálogo de determinado tipo, possuindo caráter normativo ${ }^{26}$. (FCA, p.272/274)

Para além do conceito de relevância dialética, que se refere aos tipos de diálogo, há outros constrangimentos ao tipo de argumento que podem ser utilizados em um diálogo, a depender da matéria que se está discutindo. Veja-se o seguinte diálogo entre Sócrates e Tostão após terem tomado muitas cervejas no bar. Sócrates está contando as tampinhas que estão na mesa, para saber quantas cervejas foram consumidas:

\footnotetext{
${ }^{26}$ Ao conceituar a relevância dialética Walton não deixa clara a sua extensão, mas os exemplos utilizados sugerem que ela se refira estritamente ao tipo de diálogo.
} 
Sócrates: São muitas tampinhas. Me perdi nas contas. Não sei se são 19 ou 20 tampinhas.

Tostão: São 19. Com certeza.

Sócrates: Por que?

Tostão: Porque se forem 19 tampinhas nós vamos pagar menos do que se forem 20 tampinhas. Como é melhor pagarmos menos, então só podem ser 19.

O problema da contagem de tampinhas é puramente matemático. Pouco importa o que seria melhor para Sócrates, Tostão ou o para dono do bar. Esse argumento, chamado pragmático, é irrelevante. Com esse exemplo percebemos que o tipo de problema real subjacente também determina os tipos de argumento que serão aceitos. Chamaremos a esse conjunto de argumentos aceitos de esquema argumentativo do diálogo.

O contexto institucional e prático em que está envolvido o evento discursivo (speech event) também é importante para se definir a relevância do argumento. Frequentemente há regras procedimentais a serem seguidas em um diálogo, há limitações de tempo para se discutir e limites para as decisões e cursos de ação das instituições. A relevância de um argumento, proposição ou problema tem de levar em consideração tudo isso.

Por exemplo, no processo civil brasileiro, um juiz pode indeferir os pedidos de produção de provas que entender inúteis (irrelevantes) para contribuir para a solução da causa. Ou seja, há uma regra que força a relevância dos argumentos e discussões. No processo penal brasileiro, nos casos de competência do júri, há limitações de tempo para os promotores e advogados falarem. Em arbitragens há limitações dos poderes dos árbitros. Por exemplo, diferentemente de um juiz eles não podem mandar penhorar dinheiro em conta corrente para servir como pagamento.

A partir dessas considerações podemos delinear um método passo a passo para verificar a relevância probatória de uma proposição ou argumento em um diálogo. Devemos verificar: 
(1) Tipo de diálogo

(2) Estágio do diálogo

(3) Esquema argumentativo do diálogo

(4) Contexto institucional e prático do diálogo

a. Regras procedimentais

b. Limitações práticas para obtenção de informação, decisão ou ação

Os passos para verificação da relevância probatória apresentados devem ser constantemente refeitos no momento da análise. Tanto o estágio do diálogo pode mudar, quanto o tipo de diálogo, o tipo de matéria em debate e até mesmo o contexto institucional e prático. Cada uma dessas mudanças pode fazer com que um argumento que seria relevante no momento A do diálogo deixe de ser relevante no momento B.

Por fim, vale enfatizar que para a análise da relevância probatória é fundamental que haja muita clareza sobre a questão e a tese que estão sendo debatidas no diálogo. Não raro os diálogos não avançam por falta de precisão quanto a esse ponto. Se a questão e tese em debate mudam, todos os juízos sobre a relevância podem mudar. 


\section{SECÃO I.2 FERRAMENTAS BÁSICAS}

A teoria da argumentação não é feita apenas de conceitos. Como ela pretende ser utilizada como instrumento para identificar, analisar, avaliar e criar argumentos em diálogos reais, também foram e continuam sendo desenvolvidas ferramentas para esse tipo de trabalho. Nesta seção apresentaremos o que identificamos como os três principais conjuntos de ferramentas de trabalho da teoria da argumentação: os esquemas do argumento, a reconstrução de argumentos e a diagramação de argumentos.

Os esquemas do argumento nos permitem identificar tipos de argumento e suas funções no diálogo; analisar a sua estrutura, composta por premissas e conclusões com características específicas; avaliá-los por meio da identificação de possíveis objeções; bem como criar argumentos tendo os moldes fornecidos pelos esquemas como inspiração. Os esquemas são a ferramenta mais básica e mais importante da teoria da argumentação aqui apresentada e dedicaremos a maior parte desta seção I.2 a eles.

A reconstrução dos argumentos é o trabalho de reconstruir textos e diálogos reais de modo a tornar o argumento mais claro e preciso, permitindo que se utilize a ferramenta dos esquemas do argumento com facilidade. As ferramentas da reconstrução são o conjunto de orientações e técnicas utilizadas para essa finalidade.

Por fim, a diagramação dos argumentos é o trabalho de, após a reconstrução, dispôlos de maneira que permita a sua visualização pelo analista, criando uma radiografia do diálogo. A visualização é importante pois permite que alguém rapidamente tome ciência do conteúdo e estado do diálogo, dos seus principais pontos de conflito, argumentos fortes e fracos, facilitando o desenvolvimento do diálogo em direção à melhor resposta possível.

\section{I.2.A Esquemas do Argumento}

O esquema do argumento é a estrutura inferencial pela qual um argumento opera. Cada esquema do argumento representa um tipo de argumento utilizado na prática argumentativa. Eles podem representar argumentos dedutivos, indutivos ou derrotáveis, sendo especialmente úteis para representação dos últimos. Os esquemas também servem 
para representar argumentos peculiares a contextos discursivos específicos, como a argumentação jurídica ou a argumentação científica. (AS, p.1)

Os esquemas do argumento são compostos pelas premissas e pela conclusão que o tipo de argumento requer. Além disso, são acompanhados das chamadas questões críticas (critical questions), as perguntas que se deve fazer a fim de avaliar a pertinência e o suporte à conclusão do argumento no caso concreto.

Como exemplo, segue o esquema do argumento pragmático ou argumento a partir das consequências (argument from consequences), que diz que uma coisa é valiosa em virtude das consequências que ela gera ${ }^{27}$. O esquema tal qual apresentado abaixo foi retirado do compêndio de esquemas contido no livro Argumentation Schemes (AS, p. 332) e também pode ser encontrado em Fundamentals of Critical Argumentation (FCA, p. 106).

\section{Argumento Pragmático (Positivo)}

\begin{tabular}{|l|l|}
\hline Premissa & Se A for realizado, boas consequências plausivelmente irão ocorrer. \\
\hline Conclusão & A deve ser realizado. \\
\hline
\end{tabular}

\section{Argumento Pragmático (Negativo)}

\begin{tabular}{|l|l|}
\hline Premissa & Se A for realizado, más consequências plausivelmente irão ocorrer. \\
\hline Conclusão & A não deve ser realizado.
\end{tabular}

\begin{tabular}{|l|l|}
\hline Questão 1 & $\begin{array}{l}\text { Questões Críticas } \\
\text { Quão forte é a verossimilhança (likelihood) de que as consequências } \\
\text { citadas irão (podem, devem) ocorrer? }\end{array}$ \\
\hline Questão 2 & $\begin{array}{l}\text { Que evidências dão suporte à alegação de que as consequências citadas } \\
\text { irão (podem, devem) ocorrer? Elas são suficientes para dar suporte } \\
\text { adequado à força pretendida pela alegação? }\end{array}$ \\
\hline Questão 3 & $\begin{array}{l}\text { Há outras consequências opostas (más em oposição às boas, por exemplo) } \\
\text { que deveriam ser levadas em consideração? }\end{array}$ \\
\hline
\end{tabular}

${ }^{27}$ Para a denominação "argumento pragmático", a concepção de que ele transfere o valor das consequências para as causas e uma análise detalhada de como ele pode ser utilizado, ver PERELMAN, Chaïm. " $O$ Argumento Pragmático" in Retóricas. 2a Ed. São Paulo: Martins Fontes, 2004. 
Na seção anterior, quando Sócrates e Tostão discutiam se deveríamos deixar ou não a bandeja na mesa após comer na praça de alimentação de um shopping center, tudo começou com o seguinte argumento pragmático, enunciado por Sócrates:

(Premissa 1) Deixar a bandeja na mesa gera trabalho.

(Premissa 2) O trabalho para retirar a bandeja da mesa gera empregos.

(Premissa 3) Gerar empregos é uma boa coisa.

(Conclusão) Devemos deixar a bandeja na mesa.

Para mostrar mais claramente como esse argumento encaixa no esquema do argumento pragmático acima, podemos reescrevê-lo da seguinte maneira:

(Premissa) Se deixarmos a bandeja na mesa será gerado trabalho e, por isso, plausivelmente empregos serão gerados (o que é uma boa coisa).

(Conclusão) Devemos deixar a bandeja na mesa.

Agora vale lembrar dois dos ataques a esse argumento realizados por Tostão, para mostrar como as questões críticas funcionam:

(Ataque 1) $O$ trabalho para retirar a bandeja da mesa não gera empregos. $O$ shopping apenas aproveita os empregados que ele já possui e lhes dá a função extra de recolher as bandejas. $O$ único efeito é aumentar a quantidade de trabalho dos empregados já existentes.

(Ataque 3) Deixar a bandeja na mesa atrapalha as próximas pessoas que pretendem se sentar e estão carregando as suas próprias bandejas. Atrapalhar os outros é algo ruim e deve ser evitado.

O Ataque 1 de Tostão pode ser interpretado como uma utilização tanto da Questão Crítica 1 quanto da Questão Crítica 2, pois ele critica a ideia de que deixar a bandeja na mesa gerará empregos, mostrando que isso não é verossímil, pois o trabalho gerado será apenas absorvido pelos empregados existentes. 
De outro lado, o Ataque 3 se vale da Questão Crítica 3, pois mostra que devemos levar em conta outra consequência dessa ação que age no sentido oposto da primeira. Se por um lado deixar a bandeja na mesa poderia gerar empregos, de outro pode atrapalhar as pessoas que querem sentar nas mesas da praça de alimentação.

Ilustrado o funcionamento dos esquemas do argumento, devemos passar à discussão mais detalhada da ferramenta, abordando os problemas da sua construção e da sua utilização. Não devemos esquecer que os esquemas do argumento não são uma obra acabada, mas permanecem em fase de aprimoramento.

\section{I.2.A.i Refinamento dos Esquemas}

O primeiro problema é o refinamento dos esquemas (schemes refining), ou seja, como modelá-los e apresentá-los da melhor maneira possível de modo a maximizar a sua utilidade para identificar, analisar, avaliar e criar argumentos. Diversos problemas são encontrados ao se trabalhar para refinar os esquemas: Quantas e quais devem ser as premissas? Quantas e quais devem ser as questões críticas? O que deve ser modelado como uma premissa e o que deve ser modelado como uma questão crítica e por que? Há algum método ou orientação para identificarmos premissas e questões críticas, bem como para determinarmos a maneira como uma proposição deva ser modelada?

O esquema do argumento pragmático, tal como apresentado acima, pode ser utilizado para ilustrar alguns desses problemas de refinamento. Chamaremos a versão do esquema de argumento apresentada por Walton de Versão W. Retomemos apenas a parte das premissas do argumento em sua forma positiva.

\section{Argumento Pragmático (Positivo) - Versão W}

\begin{tabular}{|l|l|}
\hline Premissa & Se A for realizado, boas consequências plausivelmente irão ocorrer. \\
\hline Conclusão & A deve ser realizado. \\
\hline
\end{tabular}

$\mathrm{Na}$ Versão W não fica claro que para o argumento existir nessa forma há pelo menos duas proposições que podem ser separadas em duas premissas distintas. Uma é a premissa que podemos chamar causal, que diz que "se A for realizado, então X ocorrerá". 
A outra é a premissa que diz "X é algo bom". Se A causa X e se X é uma boa coisa são duas discussões completamente distintas e para haver clareza é melhor que não sejam misturadas. Chegamos assim à Versão 1 do nosso esquema do argumento pragmático:

\section{Argumento Pragmático (Positivo) - Versão 1}

\begin{tabular}{|l|l|}
\hline Premissa 1 & Se A for realizado, então X ocorrerá. (causal) \\
\hline Premissa 2 & X é algo bom. (valorativa) \\
\hline Conclusão & A deve ser realizado. \\
\hline
\end{tabular}

A Versão 1 já apresenta vantagem em relação à Versão W por distinguir claramente as Premissas 1 e 2, respectivamente de cunho causal e valorativo. Mas há outro detalhe na Versão W. A Versão W diz que "boas consequências plausivelmente irão ocorrer", deixando a premissa causal como uma generalização derrotável. Isso não leva em consideração que alguém pode arguir que as consequências certamente ou provavelmente irão ocorrer, podendo a premissa causal ser uma generalização dedutiva ou indutiva. Levando em conta essa observação, chegamos à Versão 2:

\section{Argumento Pragmático (Positivo) - Versão 2}

\begin{tabular}{|l|l|}
\hline Premissa 1 & $\begin{array}{l}\text { Se A for realizado, então X (certamente, provavelmente, plausivelmente) } \\
\text { ocorrerá. (causal) }\end{array}$ \\
\hline Premissa 2 & X é algo bom. (valorativa) \\
\hline Conclusão & A deve ser realizado. \\
\hline
\end{tabular}

A Versão 2 permite dizer que "Se A for realizado, X certamente ocorrerá". No entanto, mesmo com essa certeza, a conclusão de que A deva ser realizado continuará apenas plausível, pois existe a possibilidade de que A produza outras consequências de valor oposto ao de X. Mas se a conclusão é apenas plausível, onde está a generalização derrotável que funciona como garantia? Ou seja, falta uma premissa na Versão 2. Ao solucionar o problema, chegamos à Versão 3: 


\section{Argumento Pragmático (Positivo) - Versão 3}

\begin{tabular}{|l|l|}
\hline Premissa 1 & $\begin{array}{l}\text { Geralmente se alguma coisa A gera alguma coisa boa X, então A deve ser } \\
\text { realizado. (garantia-generalização derrotável) }\end{array}$ \\
\hline Premissa 2 & $\begin{array}{l}\text { Se A for realizado, então X (certamente, provavelmente, plausivelmente) } \\
\text { ocorrerá. (causal) }\end{array}$ \\
\hline Premissa 3 & X é algo bom. (valorativa) \\
\hline Conclusão & A deve ser realizado. \\
\hline
\end{tabular}

O esquema do argumento não é constituído apenas das premissas e da conclusão, mas também das questões críticas. O próximo passo, portanto, é examinar e refinar as questões críticas da Versão W. Devemos lembrar que as questões críticas servem para construir ataques ao argumento e testar sua pertinência e suporte à conclusão no caso concreto.

$\mathrm{O}$ ataque mais simples que podemos fazer é contestar a assertiva de cada premissa e, por fim, a conclusão. Se a Premissa 2 diz que "Se A for realizado, então X ocorrerá", podemos perguntar "Se A for realizado, X realmente ocorrerá?”. Do mesmo modo, cabe a pergunta "X é realmente algo bom?". Esses ataques às premissas podem ser subdivididos, para compreensão em maior detalhe.

Quanto à premissa causal, a questão crítica pode induzir um ataque à verossimilhança e à certeza ou probabilidade de que $X$ ocorrerá. Na segunda hipótese, haverá certeza ou não, mas para as outras pode haver uma redução na força da probabilidade ou da plausibilidade. A discussão sobre a premissa causal levará a outros argumentos que terão a própria premissa causal como conclusão. Quanto à premissa valorativa, os mesmos problemas ocorrerão. Ela poderá ser algo bom ou não, ou ainda poderá ter um valor mais forte ou mais fraco.

Quanto à Premissa 1, que funciona como garantia, vale notar que atacá-la será negar a pertinência da utilização do argumento pragmático no caso concreto. Ou seja, se trata de verificar a pertinência de um tipo de argumento a um esquema argumentativo. 
Quanto à conclusão, dado que o argumento é derrotável (a garantia é uma generalização derrotável), podem ser opostos contra-argumentos. No caso do argumento pragmático, como a força da conclusão deriva do valor das consequências, o contraargumento será construído por meio de consequências de valor oposto.

Agora podemos rever as Questões Críticas da Versão W e modificá-las de modo a apresentar a Versão 4 abaixo:

\section{Questões Críticas - Versão 4}

\begin{tabular}{|l|c|}
\hline Questão 1 & $\begin{array}{c}\text { Se A for realizado, X (certamente, provavelmente, plausivelmente) } \\
\text { ocorrerá? } \\
\text { • Há certeza? } \\
\text { - Quão provável é a ocorrência de X? } \\
\text { • Quão plausível é a ocorrência de X? }\end{array}$ \\
\hline Questão 2 & $\begin{array}{r}\text { X é algo bom? } \\
\text { - Sim ou não? } \\
\text { • Quão bom é X? }\end{array}$ \\
\hline Questão 3 & Há outras consequências opostas (más em oposição às boas, por exemplo) \\
& que deveriam ser levadas em consideração?
\end{tabular}

Ao compararmos as Questões Críticas da Versão 4 com as da Versão W, podemos notar que a Questão 3 permanece igual, mas as Questões 1 e 2 mudaram. A Questão 1 da Versão W está inclusa na Questão 1 da Versão 4, na forma “Quão plausível é a ocorrência de X?”. A Questão 1 teve de ser reformulada para levar em consideração as possibilidades de X ser um evento certo ou provável.

De outro lado, a Questão 2 da Versão W desapareceu por ter um conteúdo repetitivo. Ao perguntar pelas evidências que dão suporte à alegação de que $\mathrm{X}$ irá ocorrer, ela simplesmente pergunta de outra forma se $\mathrm{X}$ ocorrerá, jogando o ônus da prova para aquele que utiliza o argumento pragmático e enuncia a premissa causal. Ao perguntar se elas são suficientes para dar o suporte adequado, a Questão 2 da Versão W simplesmente pergunta “Quão plausível (ou provável) é a ocorrência de X?". 
Ao pedir por evidências para a ocorrência de X, a Questão 2 da Versão W tenta estabelecer que, em relação ao ônus da prova, a premissa causal do argumento pragmático é ordinária ou uma suposição e demanda prova para que seja considerada verdadeira (seja aceita). A discussão sobre a classificação das premissas que formam o esquema do argumento em relação ao ônus da prova e sua importância para distinguir premissas e questões críticas será discutida logo adiante. Por ora, vamos assumir que as premissas causal e valorativa do argumento pragmático sejam ordinárias e que, portanto, a Questão 2 da Versão W não contribui para a análise do argumento. A Questão 2 da Versão 4 se baseia na discussão separada sobre a premissa valorativa, que não estava claramente separada na Versão W.

A Versão 4 pode ser desenvolvida, para detalhar os problemas na apreciação das premissas causal e valorativa, nos levando à Versão $5 .^{28}$

\section{Questões Críticas - Versão 5}

\begin{tabular}{|c|c|}
\hline Que & $\begin{array}{l}\text { Se A for realizado, X (certamente, provavelmente, plausivelmente) } \\
\text { ocorrerá? } \\
\text { • Há certeza? } \\
\text { • Quão provável é a ocorrência de X? } \\
\text { • Quão plausível é a ocorrência de X? } \\
\text { - Quanto da ocorrência de X se deve à A? Há outras causas que } \\
\text { contribuem para a ocorrência de X em conjunto com A? Há causas } \\
\text { anteriores ou posteriores à A as quais se deva atribuir a ocorrência } \\
\text { de X ao invés de A? }\end{array}$ \\
\hline Questão 2 & $\begin{array}{l}\text { X é algo bom? } \\
\text { • Sim ou não? } \\
\text { • Quão bom é X? } \\
\quad \text { - A valoração de X depende de: (a) intensidade; (b) } \\
\quad \text { duração; (c) certeza; (d) proximidade; (e) fecundidade; (f) }\end{array}$ \\
\hline
\end{tabular}

${ }^{28}$ Os questionamentos detalhados sobre a operação do argumento pragmático foram inpirados nas reflexões de Chaim Perelman em seu já citado artigo intitulado "O Argumento Pragmático". PERELMAN, Retóricas, 2004. 


\begin{tabular}{|c|c|}
\hline & $\begin{array}{l}\text { pureza; (g) extensão; e (h) sensibilidade dos indivíduos ou } \\
\text { grupos afetados. } \\
\text { - A valoração de X depende ainda de sua interpretação } \\
\text { como marco simbólico em determinada direção. } \\
\text { - Se X for a consequência de um ato, a sua valoração } \\
\text { depende ainda da análise da intenção do autor. }\end{array}$ \\
\hline Questão 3 & $\begin{array}{l}\text { Há outras consequências opostas (más em oposição às boas, por exemplo) } \\
\text { que deveriam ser levadas em consideração? } \\
\text { • Qual o conjunto de consequências decorrentes de A, para além de } \\
\text { X? } \\
\text { - Quais são as consequências de X? Quais consequências de X } \\
\text { devem ser levadas em consideração na valoração de X (e, portanto, } \\
\text { de A)? }\end{array}$ \\
\hline
\end{tabular}

A Versão 5 nos apresenta problemas avançados em relação à aplicação de um argumento pragmático. Quanto à premissa causal, as perguntas adicionadas nos levam a identificar o quanto atribuir de alguma coisa a uma causa única e também a perguntar a qual elo da cadeia causal devemos nos remontar. Quanto à premissa valorativa, coloca-se em evidência vários detalhes a serem considerados no momento da avaliação de alguma coisa. Por fim, quanto às consequências, ela nos leva a delimitar o conjunto mais amplo de consequências de um ato, bem como a nos perguntar sobre o valor das suas consequências mais longínquas. Afinal, uma consequência $\mathrm{X}$ pode gerar outra consequência $\mathrm{Y}$ de valor diferente ou oposto.

A Versão 5 coloca em evidência que um argumento, ao ser utilizado, faz parte de uma cadeia argumentativa. Podem haver várias discussões apenas sobre a premissa causal ou apenas sobre a premissa valorativa, que serão as conclusões de outros argumentos ou até mesmo extensos diálogos. Problemas de causa e consequência e de avaliação de um acontecimento (fato ou ato) são comuns e podem ser muitos. Colocar todas as discussões dentro do esquema do argumento pragmático nos parece tornar o esquema muito grande, complicado e, por consequência, pouco prático. 
Os esquemas de argumento não estão isolados no mundo, mas fazem parte de um conjunto de esquemas. No caso da Versão 5, entendemos melhor deixar as discussões muito detalhadas para esquemas do argumento próprios da relação de causa e consequência e da valoração. O esquema do argumento pragmático pode fazer referência a esses outros esquemas.

A partir das últimas considerações, chegamos à Versão 6 do esquema do argumento pragmático:

\section{Argumento Pragmático (Positivo) - Versão 6}

\begin{tabular}{|l|l|}
\hline $\begin{array}{l}\text { Premissa 1 } \\
\text { (Garantia) }\end{array}$ & $\begin{array}{l}\text { Geralmente se alguma coisa A gera alguma coisa boa X, então A deve ser } \\
\text { realizado. (generalização derrotável) }\end{array}$ \\
\hline $\begin{array}{l}\text { Premissa 2 } \\
\text { (Causal) }\end{array}$ & $\begin{array}{l}\text { Se A for realizado, então X (certamente, provavelmente, plausivelmente) } \\
\text { ocorrerá. (ordinária) }\end{array}$ \\
\hline $\begin{array}{l}\text { Premissa 3 } \\
\text { (Valorativa) }\end{array}$ & X é algo bom. (ordinária) \\
\hline Conclusão & A deve ser realizado. \\
\hline
\end{tabular}

\section{Questões Críticas - Versão 6}

\begin{tabular}{|c|c|}
\hline 01 & $\begin{array}{l}\text { Se A for realizado, X (certamente, provavelmente, plausivelmente) } \\
\text { ocorrerá? } \\
\qquad \text { Há certeza? } \\
\text { • Quão provável é a ocorrência de X? } \\
\text { • Quão plausível é a ocorrência de X? } \\
\text { (Ver esquema do argumento da relação causa / consequência) }\end{array}$ \\
\hline Questão 2 & $\begin{array}{l}\text { X é algo bom? } \\
\qquad \text { Sim ou não? } \\
\qquad \text { Quão bom é X? } \\
\text { (Ver esquema do argumento da valoração) }\end{array}$ \\
\hline Questão 3 & $\begin{array}{l}\text { Há outras consequências opostas (más em oposição às boas, por exemplo) } \\
\text { que deveriam ser levadas em consideração? }\end{array}$ \\
\hline
\end{tabular}


Da discussão do esquema do argumento pragmático da Versão W até a Versão 6, podemos extrair algumas orientações a serem observadas ao se refinar um esquema do argumento.

(1) Identifique/inclua a premissa que funciona como garantia e destaque se ela é uma generalização dedutiva, indutiva ou derrotável.

(2) Divida as proposições tantas vezes quanto elas puderem ser objeto de discussões separadas.

(3) Verifique a classificação das premissas que compõem o esquema do argumento em relação ao ônus da prova (ordinária, suposição, exceção, presunção relativa e presunção absoluta).

(4) Questões Críticas - Verifique os possíveis ataques a cada premissa e à conclusão, questionando uma por uma.

a. Faça referência a cada tipo de premissa

b. Faça referência a outros esquemas do argumento, quando for o caso

As orientações apresentadas ainda são insuficientes para o refinamento adequado de um esquema do argumento. Discutiremos agora o esquema do argumento a partir da opinião do expert (argument from expert opinion), para mostrar as dificuldades de se modelar algo como uma premissa ou uma questão crítica e a importância da classificação das proposições do esquema do argumento quanto ao ônus da prova.

$\mathrm{O}$ argumento a partir da opinião do expert transfere o valor do expert para a tese que se quer sustentar. $\mathrm{O}$ esquema tal qual apresentado abaixo foi retirado do compêndio de esquemas contido no livro Argumentation Schemes (AS, p. 310) e também pode ser encontrado no Fundamentals of Critical Argumentation (FCA, p. 87/88). Chamaremos esta de Versão W.1.

\section{Argumento a partir da Opinião do Expert - Versão W.1}

\begin{tabular}{|l|l|}
\hline Premissa 1 & $\begin{array}{l}\text { A fonte E é um expert na área do conhecimento S contendo a proposição } \\
\text { A. }\end{array}$ \\
\hline Premissa 2 & E enuncia que a proposição A é verdadeira (falsa). \\
\hline Conclusão & A é verdadeiro (falso). \\
\hline
\end{tabular}




\section{Questões Críticas}

\begin{tabular}{|l|l|}
\hline Questão 1 & Expertise - Qual é a credibilidade de E como expert? \\
\hline Questão 2 & Campo - E é um expert na área de conhecimento da qual A faz parte? \\
\hline Questão 3 & Opinião - O que E disse que implica A? \\
\hline Questão 4 & Confiança - E é pessoalmente confiável como fonte? \\
\hline Questão 5 & Consistência - A é consistente com o que outros experts dizem? \\
\hline Questão 6 & Evidência de Base - Assertiva de E é baseada em evidências? \\
\hline
\end{tabular}

É importante notar que as questões críticas poderiam ser modeladas como premissas adicionais do argumento ao invés de questões (AS, p.19/21). Observe-se a versão abaixo do mesmo esquema do argumento, apresentada por Walton, Reed e Macagno para mostrar como isso pode ser feito. Esta versão será chamada W.2. (AS, p.20)

\begin{tabular}{|l|l|}
\hline \multicolumn{2}{|c|}{ Argumento a partir da Opinião do Expert - Versão W.2 } \\
\hline Premissa 1 & $\begin{array}{l}\text { A fonte E é um expert na área do conhecimento S contendo a proposição } \\
\text { A. }\end{array}$ \\
\hline Premissa 2 & E enuncia que a proposição A é verdadeira (falsa). \\
\hline Premissa 3 & $\begin{array}{l}\text { Se E é um expert na área do conhecimento S contendo a proposição A e E } \\
\text { enuncia que a proposição A é verdadeira (falsa), então A plausivelmente é } \\
\text { verdadeira (falsa). }\end{array}$ \\
\hline Premissa 4 & E possui credibilidade como expert. \\
\hline Premissa 5 & E é um expert na área do conhecimento da qual A faz parte. \\
\hline Premissa 6 & E disse A, ou disse alguma coisa que implica A. \\
\hline Premissa 7 & E é pessoalmente confiável como fonte. \\
\hline Premissa 8 & A é consistente com o que outros experts dizem. \\
\hline Premissa 9 & Assertiva de E é baseada em evidências. \\
\hline Conclusão & A é verdadeiro (falso). \\
\hline
\end{tabular}

As Premissas 4 a 9 da Versão W.2 representam assertivas que respondem às Questões Críticas 1 a 6 daVersão W.1. No entanto, a Versão W.1 apresenta vantagens práticas em sua forma de apresentação, o que a torna preferível. 
Em primeiro lugar, a Versão W.1 apresenta o núcleo (core) de um argumento a partir da opinião do expert, o que facilita sua identificação em diálogos reais (AS, p.20). Ao utilizar esse tipo de argumento, geralmente não se enunciam as Premissas 3 a 9 listadas na Versão W.2. A Premissa 4, por exemplo, costuma-se assumir como verdadeira, tratando-se de uma suposição, e a Premissa 7 costuma-se presumir verdadeira, constituindo uma presunção relativa.

Aqui fica clara a relação entre a classificação de uma proposição quanto ao ônus da prova e a escolha por modelá-la nos esquemas como premissas ou questões críticas. Para destacar o núcleo do argumento, recomenda-se que sejam modeladas como premissas apenas as proposições classificadas como ordinárias, e as demais (suposições, exceções e presunções relativas) sejam modeladas como questões críticas.

A classificação de uma proposição a ser incluída em um esquema do argumento depende da interpretação que se faz do esquema do argumento, levando em consideração a área do conhecimento com a qual se está lidando. A seguir um exemplo (Versão W.3) de classificação feita por Walton, Gordon e Prakken para o esquema do argumento a partir da opinião do expert ${ }^{29}$.

\section{Argumento a partir da Opinião do Expert - Versão W.3}

\begin{tabular}{|l|l|}
\hline Premissa 1 & E é um expert na área do conhecimento S contendo a proposição A. \\
\hline Premissa 2 & E enuncia que a proposição A é verdadeira (falsa). \\
\hline Suposição 1 & E possui credibilidade como expert. \\
\hline Suposição 2 & A é baseado em evidências. \\
\hline Exceção 1 & E não é confiável. \\
\hline Exceção 2 & A não é consistente com o testemunho de outros experts. \\
\hline Conclusão & A é verdadeiro (falso). \\
\hline
\end{tabular}

É importante, ao construir o esquema, verificar as implicações decorrentes quanto ao ônus da prova. Na Versão W.3 acima, dizer que o expert não é confiável (Exceção 1) dependerá de prova por parte de quem alega que ele não é confiável. De outro lado, o mero

${ }^{29}$ GORDON, PRAKKEN, WALTON, 2007, p. 20 
questionamento pelas evidências que baseiam a opinião do expert (Suposição 2) jogará o ônus da prova para o outro lado, demandando que o expert mostre que sua opinião está baseada em evidências.

As escolhas de ônus da prova feitas no esquema parecem razoáveis, pois alocam o ônus a quem tem mais facilidade de produzir a prova. Quanto à Exceção 1, é mais fácil provar um fato que torne alguém não confiável do que provar vários fatos a fim de mostrar que alguém é confiável. Ademais, pode-se presumir que as pessoas são confiáveis, o que também justifica a escolha do ônus da prova da premissa . Quanto à Suposição 2, é fácil para o expert mostrar que tem evidências que baseiam suas afirmações. Por conta desta facilidade, não há perdas em se permitir que o simples questionamento mude a alocação do ônus da prova.

Além de ajudar a identificar o argumento por destacar o seu núcleo, separar as suposições, exceções e presunções relativas como questões críticas também facilita a avaliação do argumento (AS, p.20). Uma vez aceitas as premissas ordinárias, o argumento é plausível e dá suporte à conclusão, mas o rol de questões críticas oferece diferentes maneiras de devolver o ônus da prova a quem utiliza o argumento. Essa estrutura fornece muita clareza sobre o detentor do ônus da prova após cada argumento ou ataque.

Por fim, a separação de premissas e questões críticas desse modo auxilia a diagramação do argumento (AS, p.21). É muito mais fácil apresentar visualmente um argumento com duas premissas (como na Versão W.1) do que um argumento com nove premissas (como na Versão W.2).

A discussão sobre o esquema do argumento a partir da opinião do expert nos traz algumas novas lições sobre o refinamento dos esquemas:

(5) Classifique as proposições quanto ao ônus da prova, verificando os efeitos que serão produzidos na sua alocação, em um diálogo real, e levando em consideração a área do conhecimento para a qual o esquema do argumento está sendo construído. 
(6) Após classificar as proposições que compõem o esquema do argumento em relação ao ônus da prova, modele as ordinárias como premissas e as suposições, exceções e presunções relativas como questões críticas.

Após a discussão dos dois esquemas acima e as lições retiradas do exemplo de cada um, podemos traçar algumas conclusões quanto ao refinamento dos esquemas do argumento.

Os esquemas do argumento devem ser construídos de modo a maximizar a sua utilidade para identificar, analisar, avaliar e criar argumentos. Deve ser observado ainda o efeito gerado na alocação do ônus da prova, a sua adequação em relação à área do conhecimento pertinente e o fato de que os esquemas do argumento não estão isolados no mundo, mas pertencem a um conjunto de esquemas. Para refinar um esquema de argumento podemos seguir o roteiro abaixo:

(1) Tipo de Argumento e Garantia - A fim de identificar o tipo de argumento (dedutivo, indutivo, derrotável) deve ser identificada e incluída a premissa que funciona como garantia e destacado se ela é uma generalização dedutiva, indutiva ou derrotável

(2) Proposições - As proposições que formarão as premissas ou questões críticas devem ser divididas tantas vezes quanto puderem ser objeto de discussões separadas.

(3) Classificação das Proposições (Ônus da Prova) - Cada proposição deve ser classificada conforme o ônus da prova a ela associado (ordinária, suposição, exceção, presunção relativa, presunção absoluta), observando-se o seguinte:

a. Efeitos produzidos na alocação de ônus da prova em um diálogo real;

b. Área do conhecimento para qual o esquema do argumento está sendo construído.

(4) Premissas e Questões Críticas - As proposições ordinárias devem ser modeladas como premissas e as demais como questões críticas.

(5) Questões Críticas Adicionais - Estabeleça uma questão crítica para cada premissa e para a conclusão. 
(6) Revisão das Questões Críticas - Reveja as questões críticas, observando o seguinte:

a. Para as questões críticas dirigidas diretamente às premissas e à conclusão, faça referência a cada tipo de generalização ou afirmação possivel.

b. Quando for o caso, faça referência a outros esquemas do argumento para discussões mais detalhadas.

\section{I.2.A.ii Classificação dos Esquemas}

O segundo problema a ser enfrentado é o da classificação dos esquemas (schemes classification), ou seja, como agrupar e organizar esquemas de argumento em um conjunto. A classificação tem por objetivo ajudar o analista a procurar o esquema do argumento aplicável ao caso com o qual está lidando, a partir de uma primeira compreensão das linhas gerais da estrutura do argumento (AS, p.347). Em última instância, a classificação ajuda a cumprir os objetivos da teoria da argumentação, ou seja, ajuda a identificar, analisar, avaliar e criar argumentos.

Importante ressaltar que para tornar a classificação mais útil não se pressupõe que o analista conheça todos os detalhes da estrutura do argumento específico utilizado no caso. É possível encontrar um esquema do argumento apenas com uma compreensão geral, pois há esquemas de argumento que podem ser compreendidos como subespécies de outros esquemas de argumento (AS, p.347).

A classificação dos argumentos, portanto, deve ser algo próximo à taxonomia do sistema natural elaborada pelo sueco Carolus Linnaeus (popularmente conhecido como Lineu) no livro Systema Naturae de $1735^{30}$. O modelo de Lineu apresenta não apenas uma árvore de classificação hierárquica, do mais geral (reinos) até o particular (espécies), como também critérios para a classificação em cada nível hierárquico e para as subdivisões dentro dos níveis. (AS, p.360)

\footnotetext{
${ }^{30}$ Apesar de no colegial ouvirmos falar de Lineu ao estudar a taxonomia dos seres vivos em Biologia, a obra original de Lineu não tratava apenas deles e dividia a natureza em três reinos: animal, vegetal e mineral.
} 
Vários problemas podem ser encontrados nesse empreendimento. Frequentemente há dificuldade em classificar esquemas de argumento como subespécies de outros, principalmente quando se observa a utilização prática dos tipos de argumento (AS, p.347). No geral esses problemas nos parecem derivar da falta de clareza da composição dos esquemas de argumento (ver seção anterior), bem como dos critérios de classificação. Mesmo que existentes, por vezes os critérios parecem imprecisos, insuficientes ou desprovidos de uma justificativa adequada para a sua escolha.

Nesta seção apresentaremos as tentativas de classificação de Walton, Reed e Macagno e de Perelman e Olbrechts-Tyteca ${ }^{31}$. Ao passar por cada experiência examinaremos os critérios utilizados e sua justificativa e retiraremos lições de cada uma. Ao final, proporemos que a função específica dos argumentos na argumentação prática, e a origem da sua força podem ser critérios úteis para o desenvolvimento de uma nova classificação. Do mesmo modo, defenderemos que pode haver diferentes classificações conforme a área do conhecimento. No Capítulo 2, utilizando as lições desta seção, apresentaremos uma proposta de classificação que entendemos útil para a argumentação jurídica.

Walton, Reed e Macagno realizam uma primeira grande divisão das categorias: argumentos de raciocínio (reasoning), argumentos baseados-em-fonte (source-based) e argumentos aplicadores de regras (applying rules to particular cases). Os argumentos de raciocínio são aqueles que fazem parte de uma cadeia de inferências. Os argumentos baseados-em-fonte são aqueles que dependem de uma fonte, isto é, de um agente que esteja em posição de saber alguma coisa. Por fim, os argumentos aplicadores de regras são aqueles que tentam mostrar como uma situação concreta se encaixa em alguma regra mais geral. (AS, p. 348/349)

Cada uma dessas categorias mais gerais apresenta subcategorias e, finalmente, em um terceiro nível hierárquico, os esquemas de argumento por espécie. Segue um resumo mostrando apenas os dois primeiros níveis hierárquicos, baseado no quadro apresentado pelos próprios autores: (AS, p.348/350)

\footnotetext{
${ }^{31}$ Todas discutidas no livro Argumentation Schemes, Cap. 10, p.348/363.
} 
- Raciocínio

1. Raciocínio Dedutivo

2. Raciocínio Indutivo

3. Raciocínio Prático

4. Raciocínio Abdutivo

5. Raciocínio Causal

- Baseados-em-fonte

1. Argumentos a partir da posição de saber

2. Argumentos a partir do comprometimento

3. Argumentos atacando a credibilidade pessoal

4. Argumentos a partir da aceitação popular

- Aplicadores de Regras

1. Argumentos baseados em casos

2. Argumentos derrotáveis baseados em regras

3. Argumentos de Classificação Verbal

4. Argumentos encadeados conectando Regras e Casos

Ao apresentar a classificação, Walton, Reed e Macagno insistem que ela é muito geral e precisa ser muito desenvolvida conforme os avanços no campo de estudo. (AS, p.351) A classificação nos parece bastante deficiente e pouco útil. Não são claros os critérios para a classificação mais ampla, os critérios para as subcategorias são inexistentes (não há nenhuma explicação além do próprio título da subcategoria) e as subespécies de esquemas de argumento muito parecidos não parecem estar agrupadas de nenhum modo.

Como críticas mais específicas, primeiro, podemos dizer que não há nenhuma clareza na categoria "raciocínio". O nome só parece trazer confusão, e pode-se dizer que qualquer argumento que faça parte de uma argumentação real pertencerá a alguma cadeia argumentativa. Assim, qualquer argumento poderia pertencer a essa categoria. As 
subcategorias de raciocínio dedutivo e indutivo não indicam se todo argumento desse tipo deva lá estar incluído, sendo todas as outras categorias e subcategorias compostas apenas por argumentos derrotáveis. Por exemplo, argumentos que aplicam regras podem aplicar uma regra universal, tornando-se difícil decidir entre classificá-los na categoria "raciocínio" ou na categoria "aplicadores de regras".

Dado o baixo grau de desenvolvimento da classificação, não nos parece construtivo ocupar mais tempo tecendo outras possíveis críticas, principalmente quanto à escolha das espécies. Afinal, nem as categorias mais gerais parecem adequadas.

Contudo, algumas lições proveitosas ainda podem ser extraídas dessa proposta. Em primeiro lugar, a categoria baseados-em-fonte nos remete à ideia de que alguns argumentos extraem sua força e o seu convencimento da fonte que os sustentam. Ou seja, a procedência da força de um argumento pode servir como critério para a divisão dos argumentos em categorias. Em segundo lugar, a categoria "aplicadores de regras" nos leva à ideia de que aqueles argumentos desempenham uma função específica na argumentação - aplicar uma regra corretamente. A função desempenhada pelo argumento também pode servir de critério para a classificação. Parece-nos que parte da confusão da proposta de Walton, Reed e Macagno advém do fato de haver, em uma mesma categoria hierárquica, dois critérios distintos para a classificação — origem da força e função desempenhada.

A proposta de Perelman e Tyteca no Tratado da Argumentação (1958) (“TA apresenta como distinção fundamental aquela entre os processos de ligação e dissociação ${ }^{32}$ :

\footnotetext{
“Entendemos por processos de ligação esquemas que aproximam elementos distintos e permitem estabelecer entre estes uma solidariedade que visa, seja estruturá-los, seja valorizá-los positiva ou negativamente um pelo outro. Entendemos por processos de dissociação técnicas de ruptura com o objetivo de dissociar, de separar, de desunir elementos considerados um todo, ou pelo menos um conjunto solidário dentro de um mesmo sistema de pensamento." (grifos nossos)
}

\footnotetext{
${ }^{32}$ PERELMAN, OLBRECHTS-TYTECA, 2005, p.215.
} 
Os processos de ligação podem ser de três tipos. Os argumentos quase-lógicos são comparáveis a raciocínios formais, lógicos ou matemáticos e retiram sua força da proximidade com esses modos de raciocínio. Eles possuem dois componentes, um esquema formal, que molda a construção do argumento e operações de redução, que visam a tratar os elementos de forma a caber dentro desse esquema. As operações de redução em si não podem ser justificadas por argumentos quase-lógicos. (TA, p.216 e p.219/221)

Os argumentos baseados na estrutura do real se aproveitam da estrutura das coisas para entre elas estabelecer alguma espécie de vínculo. São subdivididos naqueles que apresentam ligações de sucessão, ou seja, um vínculo causal e uma relação que se opera no tempo, e nos que apresentam uma relação de coexistência, que se dá entre uma essência e as suas manifestações concretas. Como exemplo de relação de coexistência, está aquela entre ato e pessoa, pois, em alguma medida, os atos de uma pessoa dizem algo sobre quem ela é (sua essência). (TA, p.216, p.298/302 e p.333/337)

Por fim, os argumentos que fundamentam a estrutura do real, que são subdivididos naqueles que se fundamentam no caso particular para, a partir dele, extrair o que é (ou deve ser) a regra geral do real, e aqueles que se fundamentam no raciocínio por analogia, que busca estruturar a ligação entre dois elementos de modo similar à ligação que se faz em outros campos do conhecimento ou da realidade. (TA, p.216/217, p.399 e p.423/424)

Segue quadro esquemático elaborado a partir da obra contendo apenas as categorias, sem indicação das espécies de argumentos (ou técnicas argumentativas, como denominam os autores):

- Processos de Ligação

\section{Argumentos Quase-Lógicos}

2. Argumentos baseados na estrutura do real

2.1 Relação de Sucessão

2.2 Relação de Coexistência

3. Argumentos que fundamentam a estrutura do real

\subsection{Fundamento no Caso Particular}




\subsection{Analogia}

\section{- Processos de Dissociação}

De maneira mais clara que Walton, Reed e Macagno, Perelman e Olbrechts-Tyteca apresentam, como critérios de classificação, a função desempenhada pelos argumentos (ligação e dissociação) e a origem de sua força (quase-lógicos, baseados na estrutura do real). Desde logo verifica-se que a classificação peca pela falta de uniformidade na aplicação dos critérios em cada nível hierárquico, pois os argumentos que fundamentam a estrutura do real estão agrupados pela função que desempenham e não pela origem de sua força, como os quase-lógicos e os baseados na estrutura do real.

Por ora, mais do que procurar os defeitos da classificação é importante notar a recorrência dos critérios de função na argumentação e de origem da força nas tentativas. As experiências sugerem que eles são critérios importantes. Entretanto, eles não são aplicados de maneira rigorosa em cada nível hierárquico, gerando confusão. Além disso, as experiências mostram funções diferentes (aplicar regras, ligar, dissociar, fundamentar a estrutura do real) e origens da força diferentes (fonte do argumento, similaridade com o raciocínio formal, estrutura do real), o que indica a necessidade uma reflexão mais profunda sobre os critérios. Quais são as diferentes funções que um argumento pode desempenhar na argumentação? Quais são as possíveis fontes de força de um argumento?

Levando em consideração o objetivo de desenvolver uma classificação simples e útil para o usuário, é importante pensar ainda no conjunto de argumentos relevantes a serem classificados. Devem aparecer na classificação preferencialmente os argumentos mais utilizados, sob pena de nos depararmos com um conjunto excessivamente complexo. Como este conjunto pode ser alterado em virtude da área do conhecimento, ela será um fator relevante na elaboração de uma classificação.

Em primeiro lugar, o tipo de inferência pode variar conforme a área do conhecimento. Por exemplo, esquemas de argumentos derrotáveis serão mais importantes para advogados e juízes do que para biólogos ou físicos. 
Em segundo lugar, em áreas do conhecimento diferentes, as funções mais importantes da argumentação podem ser diferentes. Em Direito, por exemplo, aplicar regras possui uma relevância especial que pode não se repetir em outras áreas do conhecimento, como a Economia. Como consequência, subespécies de um esquema de aplicação de regras podem fazer parte do conjunto relevante da classificação de argumentos no Direito, mas não na Economia.

A possibilidade de uma classificação geral da teoria da argumentação que envolva todos os argumentos dependerá da possibilidade de se compreender todos os argumentos de todas as áreas do conhecimento como subespécies detalhadas de esquemas de argumento fundamentais. Tal compreensão depende de maiores investigações sobre os esquemas de argumento e de um método mais claro de elaboração de um esquema, na linha do que foi apresentado na seção I.2.A.i acima, sobre refinamento dos esquemas. Uma proposta preliminar de classificação útil para o Direito será apresentada no Capítulo 2.

\section{I.2.B Reconstrução dos Argumentos}

Os discursos, textos e diálogos reais não costumam ser apropriados a uma análise a partir da teoria da argumentação aqui exposta. Faltam premissas, faltam conclusões, não há clareza quanto ao sentido do argumento, há repetições de um mesmo ponto, raramente há precisão quanto às teses defendidas por cada parte no diálogo, e, por vezes, sequer há definição sobre a questão debatida.

Praticamente todo diálogo, discurso ou texto real terá de ser reconstruído ${ }^{33}$ para que possa ser analisado propriamente. A reconstrução criará uma representação do diálogo real com a qual poderemos trabalhar de maneira adequada. Como toda representação, o processo de reconstrução seleciona e destaca determinados aspectos dos diálogos reais em detrimento de outros. O critério básico que orienta essa reconstrução é a finalidade de

\footnotetext{
${ }^{33}$ No Fundamentals of Critical Argumentation, Walton aborda o processo de reconstrução rapidamente, ao tratar da diagramação de casos difíceis (p. 162/167). Nesta oportunidade, o autor faz referência ao livro Reconstructing Argumentative Discourse, de Frans H. Van Eemeren, Rob Grootendorst, Sally Jackson e Scott Jacobs ("RAD"). Para esta seção tomaremos por base esse último livro, que trata com maior cuidado do processo de reconstrução, o qual consideramos uma ferramenta fundamental da teoria da argumentação.
} 
resolver a questão dada (RAD, p.37/38) de acordo com os parâmetros estabelecidos pela teoria da argumentação aqui exposta.

Dado o objetivo de resolver a questão dada, ao proceder à reconstrução o analista deve buscar extrair do diálogo real os seguintes elementos:

(1) Questão e Tese - a(s) questão(ões) em debate e a(s) tese(s) sobre ela(s);

(2) Pontos de Vista - as posições dos participantes do diálogo em relação às questões;

(3) Argumentos, Premissas e Conclusões - os argumentos, premissas e conclusões, explícitos ou implícitos, que as partes utilizam para sustentar seu ponto de vista;

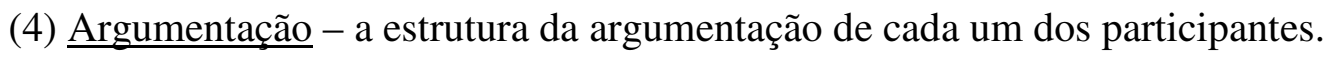

(Elaborado a partir de RAD, p.60) ${ }^{34}$

Ao extrair os elementos acima do diálogo real para construir a sua representação, podemos compreender o trabalho do analista como uma transformação que realiza quatro operações básicas: subtração (deletion), adição (addition), permutação (permutation) e substituição (substitution). Ainda que a classificação dessas operações seja didática e não represente necessariamente o modo de proceder do analista, ela nos ajuda a compreender como o processo de reconstrução seleciona e organiza os elementos que farão parte da representação. (RAD, p.61/62)

(A) Subtração - Tem por objetivo remover toda informação redundante ou irrelevante para fins de construção dos argumentos e resolução da questão dada.

(B) $\underline{\text { Adição }}$ - Tem por objetivo tornar explícitas as informações implícitas e preencher os passos faltantes no diálogo, de modo a contribuir para a resolução da questão dada. Pode se dar, por exemplo, por meio da adição de questões, de premissas ou de conclusões.

\footnotetext{
${ }^{34}$ No original, os autores tratam apenas das questões ("points at issue") e não das teses. Entendemos que é mais completo e coerente adicionar as teses sobre as questões, que foram apresentadas como um conceito distinto mais acima. (Seção I.1) Do mesmo modo, os autores tratam apenas dos argumentos e não das premissas e conclusões. Entendemos mais preciso destacar também as premissas e conclusões, pois são geralmente elas que estão implícitas e não o argumento inteiro.
} 


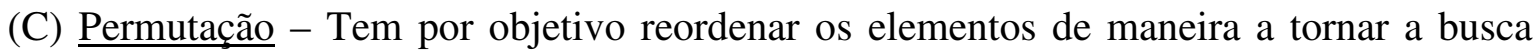
pela resolução da questão dada o mais clara possível. Não há necessidade de seguir o tempo real em que os argumentos e elocuções se sucedem. Como exemplo de aplicação, os elementos podem ser reordenados de acordo com os estágios do diálogo.

(D) Substituição - Tem por objetivo melhorar a apresentação dos elementos do diálogo de maneira a torná-los os mais claros e precisos possível. De um lado, busca garantir a uniformidade da notação dos argumentos. Por exemplo, várias formulações diferentes de um mesmo argumento são transformadas em uma só; elementos que apresentam a mesma função são apresentados da mesma maneira (por exemplo, uma pergunta retórica que funcione como um argumento será apresentada como um argumento). De outro lado, formulações vagas e ambíguas são substituídas por formulações precisas e bem definidas.

Todas essas operações de transformação estão sujeitas a crítica. A subtração depende de juízos sobre a irrelevância de uma premissa ou argumento. A adição depende de saber se um argumento ou premissa está realmente implícito e pode ser atribuído a um participante no diálogo, ou, ainda, se um determinado argumento ou premissa, ao ser preenchido, é a melhor forma de representar o diálogo ou de contribuir para resolver a questão dada. A permutação pode depender do modo como a ordem dos argumentos contribui para torná-los mais fortes. A substituição depende fortemente da interpretação das formulações do diálogo real. As diferentes formulações realmente querem dizer a mesma coisa? Aquela formulação vaga e imprecisa queria dizer especificamente isso? Ou ainda, essa é a melhor maneira de especificar o significado daquela formulação vaga e imprecisa e de tornar o argumento o melhor possível?

Parte das discussões sobre as operações de transformação estão relacionadas a uma tensão entre o ideal normativo, que busca a melhor argumentação para resolver a questão dada, e o empírico descritivo, composto pelas efetivas ações e intenções dos participantes do diálogo, no contexto em que estão inseridos. ${ }^{35}$ Em outras palavras, pergunta-se quais são os limites para a transformação do diálogo, tendo em vista que após a reconstrução, ele ainda tem a função de representar o que os participantes realmente discutiram. A outra

\footnotetext{
${ }^{35}$ Essa tensão entre o ideal normativo e o empírico descritivo é destacada por Eemeren et al. ao longo de todo o Reconstructing Argumentative Discourse. Ver especialmente p. 1/2 e p.37.
} 
parte das discussões está vinculada a um debate sobre o melhor argumento no caso concreto. Ou seja, ao reconstruir o diálogo, o próprio analista participa inevitavelmente do esforço para resolver a questão dada.

Levando em consideração principalmente as tensões entre o normativo e o descritivo, Eemeren et al. apontam três critérios gerais que ajudam a circunscrever os limites das transformações a serem realizadas pelo analista. Toda transformação deve ser eficaz (efficacy), bem-embasada (well-foundedness) e parcimoniosa (parsimony).

A eficácia exige que toda transformação leve a uma formulação que possa ser representada no modelo ideal e sobre a qual podem ser aplicadas as outras ferramentas da teoria da argumentação. O bom embasamento requer que toda transformação seja baseada em um elemento empírico do discurso e que sirva para contribuir para a resolução da questão dada. Por fim, a parcimônia demanda que as transformações sejam as mínimas necessárias para tornar o diálogo uma discussão crítica (ver Seção I.1.E acima), ou seja, torná-lo apto a buscar a resolução argumentativa da questão dada. (RAD, p.89)

Além de tais critérios, entendemos importante também levar em consideração o nível de detalhes e o nível de explicitação esperado para a reconstrução, bem como o propósito e a posição do analista. Por exemplo, um advogado ao contestar uma ação ajuizada contra o seu cliente, pode começar sua defesa reconstruindo a argumentação da parte contrária. Dependendo do momento do processo judicial e de quem irá analisar a causa (o juiz, o tribunal ou o júri) o nível de detalhes adequado pode variar radicalmente. Do mesmo modo, explicitar ou preencher premissas pode tornar o argumento da outra parte mais forte, o que não é desejável. A reconstrução do advogado deve evidenciar os defeitos argumentativos da parte contrária, o que também altera o modo de lidar com a reconstrução. O esforço de ver sob a melhor luz possível o que a outra parte fala certamente será atenuado, ainda que o advogado privilegie evidenciar a estrutura do argumento e aquilo que contribui para resolver a questão dada no processo. Pode ser até o mesmo o caso do advogado ignorar algum argumento da outra parte que possa prejudicar o seu cliente, e para o qual não tenha uma resposta contundente. Isso não desnatura o processo de reconstrução e não faz a escolha do advogado errada, dada a sua posição, ainda que ela possa ser criticada. 
Frente às considerações aqui desenvolvidas, ganham sentido o aviso de Walton de que não há um conjunto de regras mecânicas aplicáveis ao processo de reconstrução (FCA, p.167) e o aviso de Eemeren et al. de que toda reconstrução será apenas uma possibilidade, dentre um universo de alternativas envisadas pelo analista, que deve se sustentar por sua consistência geral e por ser mais plausível que as alternativas (RAD, p.89).

\section{I.2.C Diagramação dos Argumentos}

Após a reconstrução, estamos aptos a realizar a diagramação do diálogo. Isso significa representar o diálogo de uma forma que facilite a visualização pelo analista daquilo que interesse à argumentação, como em uma radiografia. Como dito acima, uma boa visualização ajuda o analista a tomar pé do conteúdo e estado do diálogo, dos seus principais pontos de conflito e dos argumentos fortes e fracos.

A importância da diagramação e da visualização levou ao desenvolvimento de vários programas de computador que buscam ajudar o analista nessa tarefa. Destacamos aqui o Araucaria ${ }^{36}$, utilizado por Walton, Reed e Macagno ao longo do livro Argumentation Schemes (AS, p.24) e o Carneades $^{37}$, baseado no modelo homônimo de argumentação e ônus da prova, desenvolvido por Thomas Gordon e equipe, contando com a contribuição de Walton e Prakken, dentre outros.

Não há no momento nenhuma convenção universalmente aceita (nem sequer majoritariamente aceita) para a diagramação dos argumentos, e os estudiosos e programadores continuam buscando a melhor forma de visualização. Se alguém comparar as convenções de visualização do software Carneades com aquelas apresentadas no texto Visualizing Carneades Argument Graphs ${ }^{38}$, de Thomas Gordon, poderá perceber que elas são diferentes. Ou seja, mesmo dentro de um modelo pode haver várias formas de visualizar os argumentos, e elas estão sendo testadas pelos pesquisadores.

\footnotetext{
${ }^{36} \mathrm{O}$ site do programa é http://araucaria.computing.dundee.ac.uk/doku.php. É possível realizar o download gratuito do programa pelo site.

${ }^{37} \mathrm{O}$ site do programa é http://carneades.berlios.de/. É possível realizar o download gratuito do programa pelo site.

${ }^{38}$ GORDON, Thomas F. Visualizing Carneades argument graphs. Law, Probability and Risk, 6, 1-4 (2007), p. 109-117. Disponível em http://www.tfgordon.de/publications. Acesso em 01 de fevereiro de 2012.
} 
O que nos interessa nesta seção são as discussões subjacentes à diagramação dos argumentos, que não se encerram na apresentação gráfica. Quais são os conceitos básicos utilizados na diagramação de argumentos? Quais informações devem constar no diagrama, e por que? Do ponto de vista de um usuário/analista, o que deve ser levado em consideração para tornar a ferramenta o mais útil possível?

Walton trata de cinco conceitos básicos para a diagramação de argumentos. Segundo o autor os argumentos podem ser únicos (single), convergentes (convergent), ligados (linked), seriais (serial) ou divergentes (divergent). (FCA, p. 139/148)

(1) Argumento Único - O argumento único (single argument) é aquele que possui apenas uma premissa que serve como base para inferência de uma conclusão. (FCA, p.139)

(2) Argumento Convergente - $\mathrm{O}$ argumento convergente (convergent argument) existe quando há mais de uma premissa e cada uma funciona separadamente como uma razão para suportar a conclusão. (FCA, p.140)

(3) Argumento Ligado - O argumento ligado (linked argument) existe quando duas (ou mais) premissas juntas servem ao estabelecimento de uma razão para suportar a conclusão. (FCA, p.142/p.145)

(4) Argumento Serial - O argumento serial (serial argument) existe quando a conclusão de um argumento serve de premissa para outro. (FCA, p.146)

(5) Argumento Divergente - Quando duas proposições podem ser inferidas como conclusões separadas de uma mesma premissa, há um argumento divergente (divergent argument) (FCA, p.147)

Como esta é uma seção sobre visualização, nada mais justo do que exemplificar cada um dos conceitos: 
(1) Argumento Único

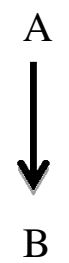

(2) Argumento Convergente

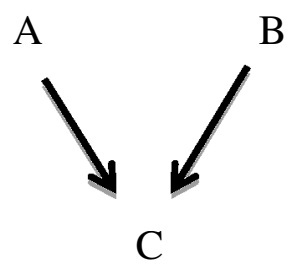

(3) Argumento Ligado

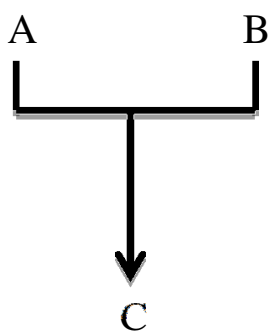

(4) Argumento Serial

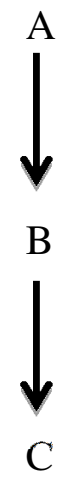




\section{(5) Argumento Divergente}

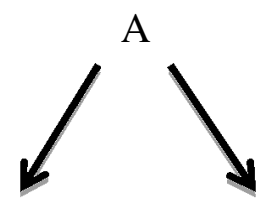

B $\quad$ C

Apesar dos conceitos básicos expostos por Walton parecerem claros, eles padecem de imprecisão. Há uma confusão entre os modos como as premissas e conclusões se relacionam, e como os argumentos se relacionam dentro de uma argumentação. Conforme exposto no início deste capítulo, argumentação, argumentos e premissas são conceitos diferentes. A argumentação é composta de argumentos, e um argumento é composto por premissas e conclusão.

Essa confusão pode causar problemas. Por exemplo, o "argumento convergente" na verdade é uma argumentação em que há dois argumentos diferentes dando sustento à mesma conclusão de modo independente. O termo "argumento convergente" pode levar à ideia enganosa de que se trata de apenas um argumento. $\mathrm{O}$ "argumento divergente" na verdade são dois argumentos que se originam a partir da mesma premissa. Para que se possa extrair duas conclusões diferentes é necessário mostrar dois argumentos diferentes que contam com uma premissa igual e com premissas ocultas distintas. Se chamamos de "argumento único" aquele que possui uma premissa, ficamos sem palavras para nos referirmos à situação em que haja apenas um argumento sustentando uma conclusão. Sem contar o fato de que o termo "argumento único" parece se referir à quantidade de argumentos e não à quantidade de premissas.

Assim, vamos rever os conceitos apresentados por Walton tendo em vista a diferença entre premissas/conclusões, argumentos e argumentação. Primeiro vamos analisar a diagramação das premissas/conclusões que em conjunto formam argumentos, depois dos argumentos que em conjunto formam a argumentação. 
$\mathrm{Na}$ diagramação um argumento pode ser classificado quanto à quantidade de premissas e quanto à sua completude, ou seja, quanto à existência de premissas ou conclusões ocultas. Quanto à quantidade de premissas, um argumento pode conter uma ou várias premissas. Um argumento pode ser completo ou incompleto e, quando incompleto, podem estar ocultas as premissas ou a conclusão.

\section{Quanto à quantidade de premissas}

Argumento de Premissa Única - Contém apenas uma premissa explícita.

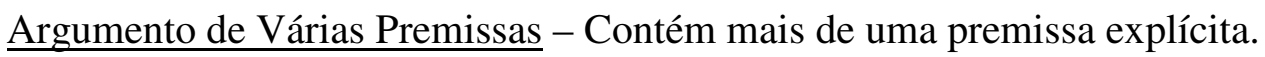

\section{Quanto à completude}

Argumento Completo - Todas as premissas e a conclusão são explícitas.

Argumento Incompleto - Pelo menos uma premissa ou a conclusão está oculta.

Quanto às premissas - Pelo menos uma premissa está oculta.

Quanto à conclusão - A conclusão está oculta.

Quanto às premissas e à conclusão - Pelo menos uma premissa e a conclusão estão ocultas.

Importante ressaltar que dentro de um argumento, sempre que houver mais de uma premissa elas serão ligadas entre si para poder fornecer suporte à conclusão.

De outro lado, a argumentação pode ser classificada quanto à quantidade de argumentos e quanto à relação entre os argumentos. Quanto à quantidade de argumentos que servem para suportar uma conclusão, podem ser um ou vários. Quanto à relação entre os argumentos há diversas possibilidades. Há argumentos seriais, convergentes e divergentes.

\section{Quanto à quantidade de argumentos}

Argumento Único - Contém apenas um argumento.

Vários Argumentos - Contém mais de um argumento. 


\section{Quanto à relacão entre os argumentos}

Argumentos Seriais - Quando a conclusão de um argumento serve como premissa para outro argumento diz-se que eles são seriais.

Argumentos Convergentes - Quando dois argumentos sustentam a mesma conclusão diz-se que eles são convergentes.

Argumentos Divergentes - Quando dois argumentos partilham pelo menos uma premissa idêntica, mas sustentam duas conclusões diferentes diz-se que eles são divergentes.

Quanto aos argumentos seriais, cabe uma observação. É possível que um argumento A sustente a premissa P1 de um argumento C, enquanto um argumento B sustente a premissa P2 do mesmo argumento C. Nesse caso, diz-se que A e C são seriais e que B e C são seriais, mas não se diz que A e B sejam seriais.

Para além dos conceitos básicos e classificações é importante divisar os tipos de informações que podem ser relevantes para constar no diagrama. Preparamos a seguir duas listas, uma sobre as premissas/conclusões e outra sobre os argumentos.

\section{Premissas/Conclusões}

(A) Enunciante - É fundamental constar no diagrama o responsável por afirmar cada proposição.

(A.1) Premissas Novas e Ocultas - Em especial, deve ser dado destaque às premissas que foram inseridas pelo analista, sejam premissas completamente novas, sejam aquelas advindas de um esforço para identificar a premissa oculta.

(B) Status da Premissa - Para que o diagrama identifique o estado do diálogo, cada premissa/conclusão deve ter seu status (verdadeira, falsa, neutra) identificado.

(C) Tipo de Premissa (ônus da prova) - Para a visualização do ônus da prova associado é importante classificar o tipo da premissa em ordinária, exceção, suposição, presunção relativa ou presunção absoluta.

(D) Standard de Prova - Ainda para a visualização do ônus da prova associado é importante identificar o standard de prova associado a cada premissa/conclusão.

(E) Suporte Premissas/Conclusão - Para verificar se o ônus da prova foi satisfeito e como, deve ser identificado o suporte dado pelas premissas à cada conclusão, destacando-se se a relação é de necessidade, probabilidade ou plausibilidade. 
(B.1) Probabilidade - Para os casos de probabilidade, vale quantificá-la.

(B.2) Plausibilidade - Para os casos de plausibilidade, também vale identificar o grau de força, quando possível.

(B.3) Suficiência/Parcialidade - Para qualquer dos casos, vale identificar se a força do argumento é suficiente para sustentar a conclusão, dado o standard de prova requerido, ou se o suporte é apenas parcial.

\section{$\underline{\text { Argumentos }}$}

(A) Esquema do Argumento / Tipo de Argumento - Identificar o esquema/tipo do argumento. Por exemplo, argumento pragmático ou argumento baseado na opinião do expert. Usando essa informação o analista pode pensar ou buscar rapidamente os ataques possíveis ao argumento.

(B) Tipo de Argumento (inferência) - Identificar o tipo de argumento; se é dedutivo, indutivo ou derrotável. É o equivalente a identificar o suporte das premissas à conclusão; se é por necessidade, probabilidade ou verossimilhança. O Esquema do Argumento / Tipo de Argumento também já fornece essa informação.

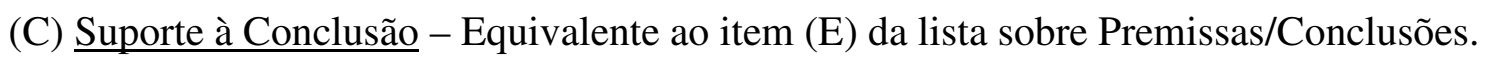

Vale anotar que a quantidade de premissas ou conclusões, a quantidade de argumentos e a relação entre os argumentos serão visualizadas no diagrama sem a necessidade de informações escritas por extenso, pela própria disposição dos elementos que representam as premissas ou conclusões e argumentos. De modo similar, a completude ou incompletude ficará evidente quando o analista adicionar uma premissa destacando que ele mesmo a enunciou. De outro lado, as informações das duas listas podem ser codificadas no diagrama por escrito ou com algum outro sinal visual (cor, por exemplo).

Para tornar o diagrama o mais útil possível para o analista é importante não perder de vista que uma ferramenta deve ser adaptada às necessidades do seu usuário tanto quanto possível. Nesse sentido, os diagramas podem variar quanto ao grau de detalhamento das informações e quanto ao nível de apresentação. 
Entendemos que pode haver três níveis de apresentação do diagrama de um diálogo: (i) O nível das proposições, em que os elementos básicos do diagrama são premissas e conclusões; (ii) o nível da argumentação, em que os elementos básicos do diagrama são os argumentos; e (iii) o nível do problema, em que os elementos básicos a serem apresentados são as questões (issues). O nível das proposições é o mais detalhado, o dos argumentos é intermediário e das questões é o menos detalhado.

Os softwares Araucaria e Carneades, bem como os textos sobre o assunto que tivemos a oportunidade de estudar, tratam apenas do que chamamos nível das proposições. O problema de trabalhar apenas nesse nível muito detalhado é que quando há um diálogo muito extenso e difícil, o diagrama fica excessivamente complexo, deixando de ser uma ferramenta útil. A discussão sobre a responsabilização dos militares que será realizada no Capítulo 3, por exemplo, é grande e complexa demais para esses softwares e para o nível das proposições. Araucaria e Carneades, no estado em que estão, foram desenvolvidos como ferramentas didáticas para o ensino da argumentação e não como uma ferramenta para um advogado ou um pesquisador que estude um grande problema com todas as suas implicações ${ }^{39}$.

No Capítulo 2 apresentaremos as convenções que adotamos para este trabalho para fins de diagramação. No Capítulo 3, colocaremos as convenções em prática, ao diagramar a discussão sobre a responsabilização dos militares pelas torturas, assassinatos e desaparecimentos forçados ocorridos durante o regime militar no Brasil.

\footnotetext{
${ }^{39}$ A informação de que o objetivo do Carneades em seu estado atual era servir como ferramenta didática nos foi fornecida pelo próprio professor Thomas F. Gordon, em vídeo-conferência realizada no dia 03 de fevereiro de 2012. Na mesma ocasião, o professor comentou a limitação do software para diagramar grandes discussões. Reiteramos nosso agradecimento ao professor Thomas F. Gordon pela oportunidade da vídeoconferência e pelos esclarecimentos.
} 


\section{CAPÍTULO II ARGUMENTAÇÃO JURÍDICA}

Neste Capítulo 2 faremos um esforço para, quando necessário, adaptar os problemas, conceitos e ferramentas apresentados no Capítulo 1 a fim de torná-los mais úteis ao desenvolvimento da argumentação jurídica. Os esforços aqui desenvolvidos são modestos e servem apenas para compor um esboço de modelo útil para o Direito. Este esboço é parcialmente baseado nos textos de Walton e de outros autores e parcialmente baseado nas nossas reflexões e experiências, especialmente na tentativa de contornar as dificuldades encontradas na aplicação da teoria do Capítulo 1 ao caso prático que será discutido no Capítulo 3.

Primeiro, apresentaremos algumas características importantes da argumentação jurídica. Segundo, apresentaremos alguns esquemas do argumento desenvolvidos para a utilização em Direito e selecionaremos outros mais gerais, mas especialmente úteis para a argumentação jurídica, todos acompanhados de uma proposta de classificação. Por fim, retomaremos o problema da diagramação de argumentos, focando as necessidades das discussões jurídicas.

\section{SECÃO II.1 ALGUMAS CARACTERÍSTICAS DA ARGUMENTACÃO JURÍDICA}

\section{Questões de Fato x Questões de Direito}

O Direito se aplica aos fatos. Isso implica que, ao discutir um caso jurídico, nos depararemos com questões de fato e questões de direito. Um problema é saber, por exemplo, se Sócrates realmente esfaqueou Tostão ou se foi outra pessoa. Trata-se de uma questão de fato. Outro problema completamente diferente é saber se a norma que anistiou os jogadores de futebol que esfaquearam outros é válida perante a Constituição Federal. Esta é uma questão de direito. 
Essa distinção nem sempre é simples de ser traçada. Por exemplo, se o corpo de Tostão não é encontrado, podemos concluir que ele tenha morrido? A pergunta pode ser vista como uma questão de fato ou como uma questão de direito. Se a pergunta for uma questão de fato o problema é saber se Tostão realmente morreu. De outro lado, se a pergunta é uma questão de direito, o problema é se podemos presumir juridicamente que a vítima morreu e condenar alguém por homicídio mesmo sem achar o corpo. A interferência do Direito na valoração jurídica das provas e na definição de presunções e ficções legais contribui para dificultar a distinção entre questões de fato e questões de direito.

Nosso objetivo aqui não é resolver as dificuldades da distinção entre questões de fato e de direito. Mas é importante apontar que a distinção existe e é utilizada. Peças redigidas por advogados costumam ser divididas entre a seção "Dos fatos" e "Do Direito", e, de modo análogo, sentenças e acórdãos são separadas em "Relatório" e "Voto".

Pensar separadamente em fatos e direito pode ser útil. Entender o que aconteceu no mundo e entender os elementos que o sistema jurídico considera relevantes e suas consequências são coisas distintas. Há muitos argumentos que podem surgir ao jurista depois de uma investigação mais apurada dos fatos. O padrão das manchas de sangue no lugar em que Sócrates supostamente esfaqueou Tostão pode revelar que a arma utilizada foi uma marreta e não uma faca. Descobrir que escolas de negros separadas de escolas de brancos geram consequências psicológicas adversas nos alunos pode justificar a revisão da doutrina do separated but equal ("separados mais iguais") e determinar que negros e brancos frequentem as mesmas escolas ${ }^{40}$.

Essas considerações influenciaram a maneira como foi realizada a pesquisa que será apresentada no Mapa Argumentativo do Capítulo 3. Deu-se especial ênfase à pesquisa histórica e ao levantamento de informações sobre o regime militar, a repressão e o processo político de anistia.

\footnotetext{
${ }^{40}$ Como no clássico caso Brown vs. Board of Education Topeka, julgado pela Suprema Corte dos Estados Unidos, com decisão apresentada pelo presidente Justice Warren (1954). Um breve comentário sobre a decisão, enfatizando a incorporação de argumentos "extralegais" pela Corte, pode ser encontrado em VIEIRA, Oscar Vilhena. Supremo Tribunal Federal: Jurisprudência política. $2^{\mathrm{a}}$ Ed. São Paulo: Malheiros, 2002, p.81/82.
} 


\section{$\underline{\text { Regras e Exceções }}$}

Os juristas, não obstante serem homens de regras, padecem de notável gosto pela exceção. Esse gosto pode ser observado na maneira como adoram discutir casos limites e fazer ressalvas. Desde jovens, pode-se vê-los nas aulas da faculdade perguntando "E se a família toda morrer ao mesmo tempo, como fica a questão sucessória?", "E se as pessoas dividirem as contas, morarem juntas e se apresentarem para a sociedade com o intuito de constituir família, mas só estiverem juntas há uma semana, configura união estável?", "E se o anão morrer de fome caso ele não possa mais ser arremessado?". Não é à toa que os juristas dizem que "O diabo está nos detalhes" e frequentemente são conhecidos como criadores de dificuldades.

Tudo isso se explica. As regras com que se trabalha em Direito costumam ser generalizações derrotáveis. Novas evidências frequentemente surgem e podem criar exceções para as regras, mudando a conclusão dos raciocínios originais. As investigações sobre os fatos (o caso concreto) podem ajudar muito com novas evidências que dão base a exceções. E há problemas que só podem ser resolvidos no caso concreto.

Cabe mencionar que o texto de um diploma normativo às vezes pode ser usado para representar a generalização derrotável, mas na maioria das vezes tem de ser reconstruído. Por exemplo, o Código Penal em seu Art. 121 dispõe "Matar alguém” "Pena: Reclusão, de seis a vinte anos". A regra reconstruída pode ser: "Se uma pessoa matar outra pessoa então será punida com pena de reclusão de seis a vinte anos". Dessa necessidade de reconstrução, por vezes se fala da distinção entre "texto" e "norma". A norma é fruto da reconstrução, é essa generalização derrotável que diz que "Se A, então X".

Qualquer conjunto de esquemas do argumento ou esboço de modelo útil para a argumentação jurídica tem de dar especial atenção aos argumentos derrotáveis e aos problemas envolvidos na aplicação de uma norma. 


\section{Contexto e objetivos}

Quando se trazem novas evidências para avaliar um caso, frequentemente não se sabe qual a consequência. Ao contrário do que ocorre no Futebol, no Direito nem sempre a regra é clara. A regra tem de ser interpretada, dando-lhe um sentido mais preciso. Para isso muitas vezes pergunta-se qual o contexto que envolve a elaboração da regra, qual o seu objetivo, porque e para que ela foi criada. Essas perguntas são válidas para regras oriundas seja do Legislativo, do Executivo ou do Judiciário, sejam estatutos ou decisões jurisprudenciais.

As noções de contexto e objetivo são fundamentais. Sem elas se torna difícil, quiçá impossível, argumentar em favor da melhor interpretação de uma regra. Vale anotar que no processo de interpretação da regra a partir do seu objetivo, pode-se comparar o caso padrão que a regra busca resolver com o caso concreto que se apresenta para decisão.

Qualquer modelo de argumentação jurídica, portanto, também deve dar atenção aos argumentos que buscam defender a melhor interpretação de uma regra ou instituto a partir de seus objetivos ou do contexto envolvido.

\section{Condições e Consequências}

Como visto, a norma jurídica apresenta o formato "Se A, então X”. De um lado, no que se pode chamar suporte fáctico ou hipótese de incidência estão as condições para que a norma seja aplicada. De outro, está a sanção, a consequência da aplicação da norma. Em razão dessa estrutura, o Direito apresenta uma configuração "mecânica". Se aconteceu uma coisa A, então a sanção deve ser X. Se aconteceram X e Y, deve ser Z. E assim por diante.

Muitas discussões jurídicas, portanto, se concentram nas condições necessárias para que se extraiam determinadas consequências. Em um nível acima se pergunta se a exigência de determinada condição ou o estabelecimento de certa consequência é justificável ou não. A pergunta sobre a melhor interpretação para uma regra pode ser assim reformulada: qual é o melhor conjunto de condições para se estabelecer uma consequência? 
Um conjunto de esquemas útil, dessarte, terá de permitir a discussão sobre as condições e consequências, tanto em sua dimensão operacional mais simples, quanto em relação à sua justificação.

\section{$\underline{\text { A Melhor Resposta }}$}

Qual o objetivo da argumentação jurídica? Buscar a melhor resposta jurídica possível para um assunto. Não é dizer tão pouco quanto parece. Falamos em melhor resposta, pois o que o Direito oferece não é “A Resposta Certa”. Em um sistema jurídico, que opera fundamentalmente com generalizações derrotáveis, não podemos exigir tanto. Há pressões de tempo para decidir, limitação de informações e o problema de estarmos construindo aquilo que queremos (assim, o objeto de estudo não é completamente separado do sujeito). A melhor resposta é a "possível", pois é a que as condições em que estamos inseridos permitem.

Na busca da melhor resposta jurídica o verbo "buscar" é importante, pois a argumentação (o diálogo) é um processo contínuo. Novas evidências e novos argumentos surgem na tentativa de se construir uma resposta cada vez melhor. Por isso é que existem processos judiciais, legislativos e administrativos, instrumentos que possibilitam o desenvolvimento da argumentação e a busca da melhor resposta. Por fim, é importante que ela seja "jurídica", pois isso compreende que ela deve observar diversos institutos e regras, toda uma tradição que limita as possibilidades argumentativas e torna os problemas decidíveis.

A adaptação de instrumentos da teoria da argumentação que será tentada a seguir tem por objetivo auxiliar na busca da melhor resposta jurídica possível para um problema concreto que já ocorreu. O caso prático em que foi feita a aplicação dos instrumentos e que também auxiliou o seu desenvolvimento, em uma via de mão dupla, será discutido no Capítulo 3. 
Anote-se que outros problemas importantes merecem estudo a fim de que os instrumentos da teoria da argumentação possam ajudar a resolvê-los, mas que por limitações do autor e do trabalho não foram abordados. Citem-se, por exemplo, os problemas relativos à construção da melhor política pública ou à compatibilização da interpretação de normas hierarquicamente diferentes.

\section{SEÇÃO II.2 ESQUEMAS DE ARGUMENTOS NO DIREITO}

Antes de apresentarmos os esquemas que adaptamos para a argumentação jurídica, apresentaremos uma proposta de classificação que os divide em duas grandes classes, conforme a sua função ${ }^{41}$. De um lado estão os argumentos de justificação e, de outro, os argumentos de operacionalização.

Os argumentos de justificação são os meios pelos quais se constrói e se atribui valor, positivo ou negativo, a uma tese ou alternativa. Um exemplo cotidiano pode ilustrar como isso funciona. Um motorista vai a um churrasco e pergunta a seu amigo se deve ir pela Avenida Paulista ou pela Alameda Santos. O amigo, que já chegou ao churrasco e viu no caminho como estava o trânsito, recomenda que o motorista siga pela Alameda Santos, pois a Avenida Paulista estava com o tráfego mais lento. Nessa situação há duas alternativas para o motorista e uma dúvida sobre a alternativa preferível. O amigo sugere uma das alternativas e argumenta em favor da sua sugestão que o motorista chegará mais rápido. Assim, ele faz a ligação entre a alternativa e algo valioso para o motorista, que é chegar mais rápido. Essa ligação, que atribui valor à alternativa, é feita por um argumento de justificação.

Os argumentos de justificação, por sua vez, são subdivididos conforme a origem da força do argumento ${ }^{42}$, podendo ser de três tipos: (i) argumento sobre a tradição, que atribui valor a uma tese ou fato A em virtude de A ser essencialmente semelhante a uma tese ou fato B, o qual já possui valor reconhecido; (ii) argumento a partir da posição de

\footnotetext{
${ }^{41}$ Lembrando que a função foi um dos critérios que identificamos como relevante para a classificação de argumentos, no Capítulo 1, Seção I.2.a.ii.

${ }^{42}$ Lembrando que a origem da força foi outro critério que identificamos como relevante para a classificação de argumentos, no Capítulo 1, Seção I.2.a.ii.
} 
saber, que atribui a uma tese ou fato o valor, ou parte do valor, da pessoa, grupo ou instituição que defende essa tese ou fato e que também constituiria quem está em melhor posição de saber sobre o assunto; (iii) argumento pragmático, que atribui à uma tese ou fato o valor, ou parte do valor, de suas consequências. $\mathrm{O}$ argumento pragmático e o argumento a partir da posição de saber, em sua subespécie a partir da opinião do expert, já foram apresentados e abordados no Capítulo 1.

No exemplo do motorista, o argumento do amigo é um argumento pragmático, que atribui à alternativa da Alameda Santos o valor da rapidez, pois a consequência de seguir pela Alameda Santos é chegar mais rápido. Se o motorista considerar que a opinião do amigo merece confiança, especialmente pelo fato de ele já ter conhecimento do tráfego na região, há ainda um argumento a partir da posição de saber que justifica a aceitação da tese da Alameda Santos como melhor caminho (quem já conhece o caminho está em melhor posição de saber algo sobre ele).

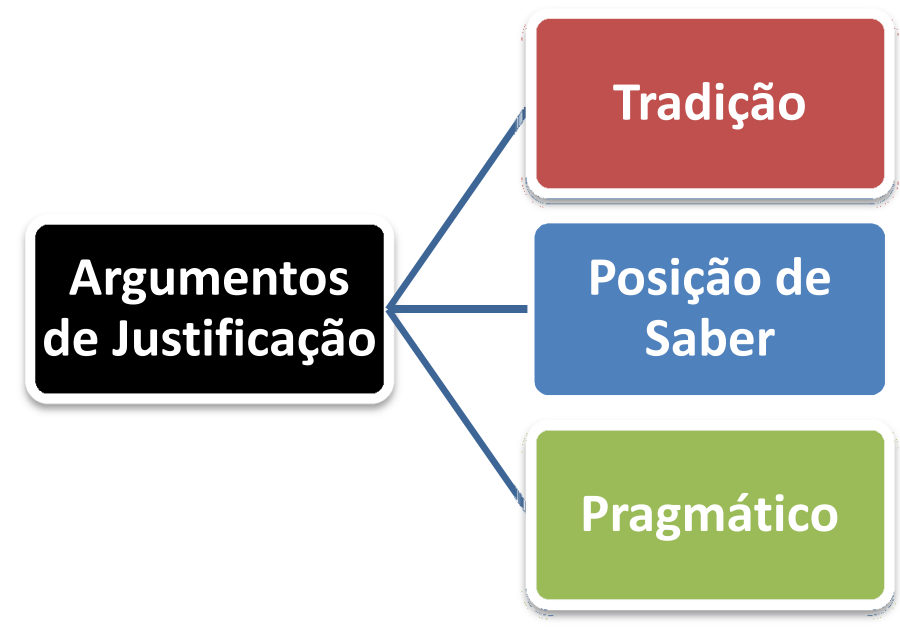

Ao se discutir a melhor decisão para um caso, esse tipo de argumento é utilizado para justificar a aplicação de uma norma bem como a melhor interpretação que se pode dar a ela, incluindo ou excluindo condições ou consequências. Mostraremos como o esquema do argumento para aplicação de uma norma jurídica pode surgir do argumento de tradição, e como o esquema do argumento pelo objetivo da lei pode ser derivado do argumento pragmático. 
Os argumentos de justificação são apenas parte do conjunto de argumentos relevantes para a argumentação jurídica. Frequentemente o debate cinge-se em saber, concretamente, se um caso é essencialmente semelhante a outro ou se as alegadas consequências de uma decisão realmente acontecerão. Por exemplo, no caso descrito há pouco, o motorista poderia objetar que o amigo passara pelo lugar há muito tempo e que o tráfego já não seria necessariamente o mesmo. Poderia ser o caso também de o motorista estar de motocicleta e o amigo de carro. Nessa hipótese, o tráfego lento que afetou o amigo não necessariamente afetaria o motorista, que poderia passar com a motocicleta entre os carros.

Em ambas as objeções, a efetivação da consequência valiosa é contestada, colocando em xeque a justificativa da escolha da Alameda Santos como alternativa preferível. Isso porque, para se dizer que o motorista chegará mais rápido, o amigo assumiu que o tráfego estaria igual e que o motorista usaria um veículo igual. A discussão sobre a igualdade dos casos e, consequentemente, sobre a aptidão da escolha para produzir as mesmas consequências, se dá em um campo mais concreto do que o da pergunta original sobre o melhor caminho. Não se está discutindo como atribuir valor a uma alternativa, mas sim, se o valor alegado para uma alternativa efetivamente se verifica no caso concreto. Em termos simples, antes se discutia o motivo de ir pela Alameda Santos, e foi respondido que era mais rápido. Agora, a pergunta é se a Alameda Santos realmente é um caminho mais rápido.

Esses argumentos que servem à discussão da aplicabilidade concreta dos argumentos de justificação, fazendo com que a construção e atribuição de valor possa ser operada na prática, serão chamados argumentos de operacionalização. Argumentos que visem a estabelecer uma relação de semelhança ou dessemelhança entre dois casos, e argumentos que discutam a relação de causalidade entre dois fatos são exemplos do tipo de argumento que se encontrará dentre os argumentos de operacionalização. No Capítulo 1, quando discutimos o esquema do argumento pragmático, mostramos que o argumento pragmático possui uma premissa causal e uma premissa valorativa, sendo que as discussões sobre a causa e a valoração poderiam ser realizadas a partir da aplicação de esquemas específicos. Aquela construção já antecipava a classificação de esquemas em argumentos de justificação e argumentos de operacionalização. 
Neste trabalho apresentaremos de modo bastante limitado algumas formas de operacionalizar as discussões sobre condições e consequências das normas jurídicas. Como dito anteriormente, este Capítulo pretende fornecer apenas algumas adaptações úteis para a argumentação jurídica a partir da Teoria da Argumentação e especialmente da obra de Walton.

\section{II.2.A Argumentos de Justificação}

\section{II.2.A.i Tradição, Justiça Formal e Aplicação de Normas Jurídicas}

Todos aqueles calejados no exercício de alguma profissão jurídica sabem com certeza uma coisa sobre a Justiça. Que é definitivamente um conceito complicado. Foram pouquíssimas as petições iniciais e contestações que lemos na vida que não terminassem clamando pela “mais lídima J U S T I Ç A !!!". Assim mesmo, com caixa alta e várias exclamações. Nunca conhecemos alguém que fosse contra a Justiça. Como mostraremos nas próximas linhas, a justiça, em seu sentido formal, possui estreita relação com o argumento sobre a tradição.

A justiça em seu sentido formal é o valor protegido pela regra de justiça, que podemos enunciar da seguinte maneira: deve-se tratar igual os essencialmente semelhantes. ${ }^{43}$ Um jurista ou filósofo mais atento logo perceberá que essa formulação é ligeiramente diferente da que estamos habituados: deve-se tratar igual os iguais. Qual a razão para essa mudança?

Para justificar essa formulação, observamos que não existe no mundo dois seres perfeitamente idênticos. Sempre que nos referimos a dois seres diferentes pelo mesmo nome, estamos nos referindo a um conceito abstrato do qual aquele ser concreto é um caso concreto. Assim, se a regra de justiça se aplica a casos concretos e não há perfeita

\footnotetext{
${ }^{43}$ A concepção da Justiça em um sentido formal e a formulação "tratar igual os essencialmente semelhantes" é de Chaim Perelman. PERELMAN, Chaïm. Ética e Direito. São Paulo: Martins Fontes, 2000, p. 160.
} 
identidade entre as coisas concretas, não adianta dizer que se devem tratar igualmente os iguais, mas sim os essencialmente semelhantes, caso contrário ela seria inaplicável. ${ }^{44}$

Tendo a regra de justiça em mente, vale recapitular o conceito de argumento sobre a tradição, isto é, aquele que atribui valor a uma tese ou fato $\mathrm{A}$, em virtude de $\mathrm{A}$ ser essencialmente semelhante a uma tese ou fato $\mathrm{B}$, o qual já possua valor reconhecido. No fundo, o argumento sobre a tradição diz que se A e B são essencialmente semelhantes devem ser tratados igualmente, sendo reconhecido a eles o mesmo valor. $\mathrm{O}$ argumento de tradição, portanto, extrai a sua força da aplicação da regra de justiça.

A regra de justiça formal é um imperativo de consistência e coerência inerente ao sistema jurídico. Não é possível admitir, em princípio, que dentro de um sistema jurídico qualquer, dois casos essencialmente semelhantes sejam tratados de maneira diferente. Se isso aparentemente ocorrer, ou alguma diferença de contexto terá de ser invocada para explicar a diferença (por exemplo, uma mudança na legislação), ou uma das decisões terá de ser identificada como errada, por atentar a outro valor protegido pelo Direito. Vale destacar ainda que é a regra de justiça formal e o argumento sobre a tradição que permitem decidir um caso com base no precedente, ou seja, no que já foi decidido no passado. Ante as considerações realizadas fica evidente quão fundamental é este tipo de argumento para a argumentação jurídica.

O esquema do argumento de tradição no Direito, em sua forma básica, pode ser apresentado da seguinte maneira:

\section{Argumento de Tradicão}

\begin{tabular}{l|l} 
Premissa 1 & Sempre que A for essencialmente semelhante a B e B tiver sido decidido
\end{tabular} (Garantia) juridicamente de maneira correta, então A deverá ser decidido do mesmo modo que B. (generalização absoluta)

${ }^{44}$ No mesmo sentido escreve Chaïm Perelman, valendo-se: (i) da crítica de Leibniz ao princípio da identidade objetiva, que afirmava não existirem dois seres idênticos; e (ii) da crítica de Frege, que afirmava a identidade dizer respeito a diferentes nomes para um mesmo objeto (abstrato) e não para uma mesma coisa (concreta). PERELMAN, 2000, p. 158 


\begin{tabular}{|l|l|}
\hline $\begin{array}{l}\text { Premissa 2 } \\
\text { (Decisão B) }\end{array}$ & B foi juridicamente decidido de modo X. (ordinária) \\
\hline $\begin{array}{l}\text { Premissa 3 } \\
\text { (Semelhança) }\end{array}$ & A é essencialmente semelhante a B. (ordinária) \\
\hline Conclusão & A deve ser juridicamente decidido de modo X. \\
\hline
\end{tabular}

\begin{tabular}{|l|ll|}
\hline \multicolumn{4}{|c|}{ Questões Críticas } \\
\hline $\begin{array}{l}\text { Questão 1 } \\
\text { (Correção de } \\
\text { X) }\end{array}$ & $\begin{array}{l}\text { X foi a decisão correta para B? Ou B deveria ter sido decidido de modo } \\
\text { Y? exção) }\end{array}$ \\
\hline Questão 2 & B foi realmente decidido juridicamente do modo X? \\
\hline $\begin{array}{l}\text { Questão 3 } \\
\text { (Semelhança) }\end{array}$ & $\begin{array}{l}\text { A é realmente essencialmente semelhante a B? } \\
\text { (ver esquemas do argumento de operacionalização }\end{array}$ & sobre \\
& semelhança/dessemelhança) & \\
\hline
\end{tabular}

Importante destacar que uma generalização absoluta é garantia do esquema do argumento. Ou seja, não é possível atacar a conclusão por meio de um argumento contrário, nem dizendo que não foi satisfeito o ônus da prova. Também não é possível opor uma exceção adicionando-se uma nova premissa. Os únicos ataques possíveis são aqueles listados nas questões críticas, dirigidos às premissas. Por exemplo, as questões críticas 2 e 3 indicam a possibilidade de se atacar respectivamente as premissas 2 e 3.

Um detalhe importante é que a questão crítica 1, na verdade, representa uma premissa que tem de ser satisfeita para que a generalização absoluta seja aplicada, a premissa "X foi a decisão correta para B". Ela aparece como uma questão crítica e não como uma premissa porque o ônus da prova associado é o de exceção, ou seja, a premissa é falsa até que se prove o contrário. Em outros termos, em Direito, se há uma decisão em um sentido, presume-se que ela seja correta até que se prove o contrário. Para os mais habituados ao sistema jurídico, vale lembrar a presunção de constitucionalidade das leis, a presunção de legalidade e veracidade dos atos administrativos e também o fato de que a coisa julgada (judicial) só pode ser desfeita em casos excepcionalíssimos, por meio de ação rescisória. 
É fácil perceber a utilização do esquema no momento da aplicação de um precedente judicial, como no exemplo abaixo:

“O Superior Tribunal de Justiça já enfrentou a questão, posicionando-se pela possibilidade de os sócios-gerentes serem incluídos no polo passivo da execução fiscal, já que, se a sociedade executada não é localizada no endereço informado à Junta Comercial, presume-se sua dissolução irregular.

Nesse sentido, são os seguintes precedentes: REsp 1017732/RS, REsp 1004500/PR e AgRg no AgRg no REsp 898.474/SP. (...)

Na hipótese dos autos, a empresa não foi localizada no endereço cadastrado na JUCESP, conforme certidões de Oficiais de Justiça (fls. 41verso, 61-verso, 64 e 71-verso) e documento de fls. 495/497-verso, inferindo-se sua dissolução irregular, nos termos da Súmula 435/STJ.

Desta forma, cabível a responsabilização dos sócios, nos termos do art. 135, III, CTN, tendo em vista a ocorrência da dissolução irregular."

(TRF3, Agravo de Instrumento $\mathrm{n}^{\circ}$ 0024081-71.2012.4.03.0000/SP, Relator Desembargador Federal Nery Júnior, decisão monocrática, DJE disponibilizado em 30.08.2012)

Reconstruindo o texto, podemos afirmar que o Desembargador menciona que nos casos em que a sociedade executada não é localizada no endereço cadastrado na Junta Comercial, presume-se a dissolução irregular e pode-se incluir os sócios gerentes no polo passivo da execução fiscal, de acordo com alguns precedentes e com a Súmula $\mathrm{n}^{\mathbf{0}} 435$, todos do Superior Tribunal de Justiça. Essa afirmação nada mais é que a Premissa 2 do Argumento de Tradição "B foi juridicamente decidido do modo X". "B" é a situação da empresa não ser encontrada no endereço cadastrado na Junta Comercial e "X" é a presunção de dissolução irregular que autoriza a inclusão do sócio-gerente no polo passivo da execução fiscal.

Em seguida, o Desembargador afirma que no caso concreto a empresa não foi localizada no endereço cadastrado na Junta Comercial do Estado de São Paulo (JUCESP). 
Desse modo, o Desembargador diz que o caso concreto "A" é essencialmente semelhante a "B", que é o caso dos precedentes citados. A conclusão é de que o caso concreto "A" deve ser decidido do modo "X", isto é, com a presunção de que houve dissolução irregular, autorizando-se a inclusão do sócio-gerente no polo passivo da execução fiscal.

As críticas possíveis são: dizer que os precedentes e a súmula citados estão errados (questão crítica 1); dizer que os precedentes e a súmula citados não decidem que se presume a dissolução irregular no caso (questão crítica 2); dizer que na verdade a situação B não é igual à situação A (questão crítica 3). No caso da questão crítica 3, por exemplo, pode-se dizer que na verdade o caso ao qual se aplicam os precedentes citados e a súmula (um caso padrão, conforme conceito do Capítulo I.1.A) não é igual ao caso concreto, por conta de alguma característica diferente, a mais ou a menos.

Apesar de ser mais fácil aplicar este esquema a um precedente, ele também pode ser aplicado às leis:

"Segundo o Art. 739-A do Código de Processo Civil: "Os embargos do executado não terão efeito suspensivo”. No caso concreto um executado opõe embargos. Assim, não há efeito suspensivo."

A Premissa 2 do esquema se revela na disposição do Art. 739-A do Código de Processo Civil. A situação B é a de um executado que opõe embargos, a decisão X é a de que tais embargos não têm efeito suspensivo. Para que a regra seja efetivamente aplicada por meio do argumento de tradição, ao dizer que no caso concreto um executado opõe embargos, está se dizendo também que o caso concreto A é essencialmente semelhante a B. Portanto, deve-se decidir do modo $\mathrm{X}$, ou seja, não atribuir efeito suspensivo aos embargos. A diferença é que a decisão aqui é tomada de antemão pelo Legislativo ao editar a lei, e não pelo Judiciário. No entanto, não deixa de ser uma decisão.

As críticas possíveis (independentemente de sua força) são: dizer que a lei está "errada", por exemplo, que ela é inconstitucional (questão crítica 1); negar que a lei diga que os embargos do executado não terão efeito suspensivo (questão crítica 2); dizer que na verdade a situação B à qual deve ser aplicado o artigo de lei não é igual à situação A do 
caso concreto (questão crítica 3). Por exemplo, pode-se dizer que no caso deve ser aplicado o $\S 1^{\circ}$ do Art. 739-A e não o caput do Art. 739-A: “O juiz poderá, a requerimento do embargante, atribuir efeito suspensivo aos embargos quando, sendo relevantes seus fundamentos, o prosseguimento da execução manifestamente possa causar ao executado grave dano de difícil ou incerta reparação, e desde que a execução já esteja garantida por penhora, depósito ou caução suficientes." Ao se dizer isso, está se mostrando que o caso padrão da situação B, que é a situação do caput do Art. 739-A não é a situação do caso concreto, cuja situação se assemelha ao caso padrão do $\S 1^{\circ}$. Em outras palavras, há condições relevantes que não estão contempladas no texto do caput do Art. 739-A, mas que têm de ser observadas para que seja tomada a decisão correta.

Ao se analisar o argumento acima quanto à aplicação do Art. 739-A pelo esquema do argumento da tradição, verifica-se a necessidade de destacar que há um caso padrão B ao qual se circunscreve a aplicabilidade do artigo de lei, o conjunto de condições em que ele se baseia. A questão crítica 3 é realizada mostrando que esse caso padrão B não é essencialmente semelhante ao caso concreto A. Não se trata de opor um ataque-exceção ao argumento de tradição, já que isso é impossível dentro do esquema do argumento da tradição, que tem por garantia uma generalização absoluta. Ataca-se a premissa 3, que diz que A e B são essencialmente semelhantes.

Observando os dois exemplos, concluímos que o esquema do argumento da tradição serve tanto para a aplicação de precedentes judiciais como para a aplicação da lei (ou outros diplomas normativos). Podemos ver com mais clareza também que há um caso pressuposto na aplicação da lei e não apenas na aplicação do precedente. No entanto, o esquema do argumento de tradição, tal como apresentado, não é a melhor maneira de discutir argumentos elaborados com base em leis, nem os que enunciam normas jurídicas.

$\mathrm{O}$ argumento de tradição pode assumir outra forma, facilitando a sua utilização para a aplicação da lei. Trata-se do esquema de argumento para aplicação de normas jurídicas. Uma das dificuldades mais corriqueiras e mais básicas de um operador do Direito é a de aplicar uma norma jurídica, um comando no formato "Se A, então X". Como discutido acima, a justificação para se aplicar uma norma é construída a partir do argumento da tradição. Contudo, aquele esquema não é o mais apto para a utilização habitual e 
identificação dos problemas que se costuma enfrentar ao se aplicar uma norma. Para isso, desenvolvemos um esquema do argumento específico para a aplicação de normas jurídicas.

Antes de apresentar o esquema, cabe apresentar os problemas que podem ocorrer na aplicação da norma jurídica "Se A, então X". O primeiro problema é que a norma pode ser inválida. Por exemplo, um decreto que desrespeita a lei ou uma lei que desrespeita a Constituição. O segundo problema é que a norma pode não estar vigente, ou seja, não tem a possibilidade de produzir efeitos jurídicos. Por exemplo, uma norma que decorra de uma lei que esteja em período de vacatio legis ou uma norma que foi implicitamente revogada por uma norma posterior. O terceiro problema está em como se pode dar a relação entre uma condição normativa A e uma consequência normativa $X$. A pode ser uma condição necessária, suficiente ou contributiva de X.

A é uma condição necessária quando sem ela X não pode existir. Por exemplo, para que uma sociedade seja constituída serão necessárias pelo menos duas pessoas ${ }^{45}$, físicas ou jurídicas.

A é uma condição suficiente quando basta A para que X exista. Por exemplo, basta ser considerado pessoa pelo ordenamento jurídico para que alguém seja capaz de ter direitos e deveres ${ }^{46}$. Dizer que $\mathrm{A}$ é suficiente para $\mathrm{X}$, não implica dizer que $\mathrm{A}$ é necessário para X. Há sujeitos de direito, capazes de direitos e deveres, que não são pessoas, como a massa falida. Contudo, é possível que A seja necessário e suficiente para $\mathrm{X}$ ao mesmo tempo. Neste caso "Se A, então X" será uma regra absoluta, baseada em uma generalização absoluta.

A é uma condição contributiva quando ela não é necessária nem suficiente, mas, conjuntamente com outras condições, contribui para que $\mathrm{X}$ exista. Por exemplo, quando se discute a existência de união estável entre duas pessoas, há vários elementos que devem ser

\footnotetext{
${ }^{45}$ No Direito Brasileiro é possível que uma sociedade se torne unipessoal por um período limitado de tempo (Art. 1.033, IV do Código Civil Brasileiro), mas isso só é possível após a sua constituição. No momento da constituição necessariamente tem de haver pelo menos duas pessoas. A Empresa Individual de Responsabilidade Limitada não é uma sociedade, tanto que foi incluída em título próprio (Título I-A) no Código Civil e não no Título referente às sociedades (Título II).

${ }^{46}$ Conforme o Art. $1^{\circ}$ do Código Civil Brasileiro. Não se deve confundir a capacidade jurídica para ter direitos e deveres com a capacidade de exercício, que pode ser limitada (relativamente incapazes ou absolutamente incapazes)
} 
considerados na análise como a coabitação e a divisão de recursos financeiros. A existência desses elementos contribui para caracterizar a união estável, mas nenhum deles é necessário nem suficiente. A tabela abaixo ajuda a mostrar as possibilidades para uma condição normativa A qualquer.

\begin{tabular}{|l|l|l|l|}
\hline Necessária & Suficiente & Contributiva & Observação \\
\hline Sim & Sim & Não & Unica e absoluta \\
\hline Sim & Não & Não & Necessária \\
\hline Não & Sim & Não & Suficiente \\
\hline Não & Não & Sim & Contributiva \\
\hline Não & Não & Não & Irrelevante \\
\hline
\end{tabular}

Importante observar que se é necessário que uma condição A não exista (-A) para que X exista, então A é uma condição suficiente para não existir X (-X). De outro lado, se é suficiente que uma condição $\mathrm{A}$ não exista (-A) para que $\mathrm{X}$ exista, então $\mathrm{A}$ é uma condição necessária para que $\mathrm{X}$ não exista $(-X)$.

Na hipótese de A, da norma "Se A, então X", não ser uma condição necessária nem suficiente, pode-se discutir quais são as outras condições relevantes para a produção de X e o seu caráter (necessária, suficiente ou contributiva). Como mostrado acima, essa é uma dúvida frequente quando se interpreta o Direito. A inclusão, exclusão e caracterização de requisitos para a produção de consequências jurídicas é objeto frequente de argumentação, devendo haver justificativas para tanto. $\mathrm{O}$ argumento pelo Objetivo da Lei (que será discutido mais adiante) é frequentemente utilizado para justificar a inclusão ou exclusão de condições para a produção de consequências normativas.

Quando há discussão sobre as outras condições relevantes para a consequência X é comum que se discutam as condições relevantes para que $X$ não exista (-X). São ataques que se apresentam como exceções à norma jurídica. É nesse sentido que operadores do Direito costumam falar de exceção. 
No caso do Art. 739-A acima, se considerássemos a norma "Se o executado opõe embargos, então não deve haver efeito suspensivo da execução", o $\S 1^{\circ}$ do mesmo artigo funcionaria como uma exceção. O efeito suspensivo deve existir uma vez cumpridos os requisitos de que: (a) haja requerimento do embargante para atribuir efeito suspensivo aos embargos; (b) os fundamentos sejam relevantes; (c) o prosseguimento da execução manifestamente possa causar ao executado grave dano de difícil ou incerta reparação; e (d) a execução já esteja garantida por penhora, depósito ou caução suficientes. Os requisitos (a), (b), (c) e (d) são condições necessárias e, em conjunto, suficientes para que seja atribuído efeito suspensivo, decisão oposta ao que previa a norma original baseada apenas no caput do Artigo 739. Assim, é necessário que pelo menos uma das condições (a), (b), (c) e (d) não exista para que não seja concedido efeito suspensivo.

Por fim, vale destacar um último problema na aplicação das normas jurídicas: como foi construída a norma N. Como mencionado no começo deste Capítulo, a norma costuma ser o fruto da reconstrução de textos, o resultado de uma atividade interpretativa. Caso questionado, o participante do diálogo tem de mostrar como chegou à norma que está invocando, seja apontando textos de lei, decisões judiciais ou outros argumentos que dão base à sua interpretação. Por vezes a norma invocada será a transcrição direta de um texto de lei, afastando o problema desde logo.

A partir dos problemas apresentados, segue o esquema do argumento de aplicação de normas jurídicas:

\section{Argumento para Aplicação de Normas Jurídicas}

\begin{tabular}{|l|l|}
\hline $\begin{array}{l}\text { Premissa 1 } \\
\text { (Garantia) }\end{array}$ & $\begin{array}{l}\text { Geralmente se há uma norma jurídica válida e vigente N que estabelece } \\
\text { que se A então X, e A é o caso, então devem ser as consequências } \\
\text { jurídicas X. (generalização derrotável) }\end{array}$ \\
\hline Premissa 2 & $\begin{array}{l}\text { A norma jurídica N estabelece que se A, então devem ser as consequências } \\
\text { jurídicas X. }\end{array}$ \\
\hline Premissa 3 & É o caso de A. \\
\hline Conclusão & Devem ser as consequências jurídicas X. \\
\hline
\end{tabular}




\section{Questões Críticas}

\begin{tabular}{|l|l|}
\hline Questão 1 & Como foi construída a norma N? (problema de interpretação) (suposição) \\
\hline Questão 2 & A norma jurídica N é válida? (exceção) \\
\hline Questão 3 & A norma jurídica N é vigente? (exceção) \\
\hline Questão 4 & $\begin{array}{l}\text { Há exceções à norma jurídica N (condições para que Não-X)? Há no caso } \\
\text { concreto outras condições necessárias, suficientes ou contributivas de X? } \\
\text { Como classificar a(s) condição(ões) presentes em A (necessária, suficiente } \\
\text { ou contributiva)? }\end{array}$ \\
\hline Questão 5 & É realmente o caso de A? \\
\hline
\end{tabular}

No esquema do argumento, “A” pode representar uma condição ou um conjunto de condições. A questão crítica 1 faz parte da generalização derrotável, pois trata da existência da norma, mas não foi modelada como premissa pois o ônus da prova associado é o de uma suposição. As questões críticas 2 e 3 fazem parte da generalização derrotável, mas não foram modeladas como premissas pelo fato do ônus da prova associado ser o de exceção. A garantia é uma generalização derrotável, pois existe a possibilidade de que A não seja uma condição (nem conjunto) necessária e suficiente (e, portanto, única e absoluta) para X. Essa possibilidade está contemplada na questão crítica 4. Por fim, a questão crítica 5 questiona simplesmente se realmente é o caso de A.

A relação do esquema do argumento da aplicação de normas jurídicas com o esquema do argumento de tradição é clara. A premissa "um caso foi decidido de maneira X" se transforma na norma jurídica N, na qual "Se A, então X" (Premissa 2). A discussão sobre a decisão do caso — se foi correta ou não — é a discussão sobre a interpretação, a validade e a vigência da norma jurídica (questões críticas 1, 2 e 3). A premissa "os casos A e B são essencialmente semelhantes" dá lugar à afirmação de que A é o caso (Premissa 3). Por consequência surge a questão crítica relativa à presença de outras condições no caso concreto relevantes para $X$ ou Não-X além daquelas previstas em A (questão crítica 4). Surge ainda a questão de se é realmente o caso de A (questão crítica 5).

$\mathrm{O}$ argumento de tradição se processa de um caso para outro caso essencialmente semelhante, por isso ele é um argumento dedutivo com uma generalização absoluta. O argumento da aplicação de normas jurídicas não opera a partir de um caso para outro, mas 
a partir de uma norma para um caso. Ele pressupõe que a norma é uma construção que não dispõe sobre todas as condições relevantes (suficientes, necessárias e contributivas, com a medida de sua contribuição) para produção de uma consequência jurídica. O caso padrão pressuposto na norma se encontra incompleto. Essa incompletude abre espaço para discussão, e por isso o argumento é derrotável.

O esquema básico do argumento sobre tradição destaca o papel do caso concreto e do caso a caso na construção do Direito, bem como nos remete à tradição de Common Law, focada na construção jurisprudencial do Direito. De outro lado, o esquema do argumento da aplicação de normas jurídicas destaca um aspecto quase mecânico do Direito, o da verificação de condições e suas consequências. Remete-nos à tradição de Civil Law, focada na construção do Direito a partir de diplomas normativos, com textos que buscam representar as próprias normas jurídicas. Apesar das diferenças, é importante destacar que os dois esquemas buscam retratar o intuito do Direito de se manter consistente e coerente; seja em um âmbito micro, de caso a caso, seja em um plano macro, de regras que estabelecem condições e consequências para uma generalidade de casos.

Os dois esquemas são duas faces de uma mesma moeda e são mais ou menos convenientes em momentos distintos. No entanto, como pode ser percebido, ambos são insuficientes para dar conta dos problemas que geralmente ocorrem na prática. Isso era esperado, afinal representam apenas um dos três tipos de argumentos de justificação, e existem ainda os argumentos de operacionalização. As discussões muitas vezes se concentram nos argumentos de operacionalização. Os argumentos de justificação apenas indicam os caminhos mais gerais das possíveis discussões.

\section{II.2.A.ii Posição de Saber}

$\mathrm{O}$ argumento a partir da posição de saber é aquele que atribui a uma tese ou fato o valor, ou parte do valor, da pessoa, grupo ou instituição que defende essa tese ou fato e que também constituiria quem está em melhor posição de saber sobre o assunto. Um dos seus subtipos mais conhecidos é o argumento a partir da opinião do expert, que foi discutido no Capítulo 1, Seção I.2.a.i, acima. 
Para avaliar a importância desse tipo de argumento para o Direito, utilizemos o expediente de imaginar como seria o Direito sem ele. Teríamos de abandonar o uso dos peritos, ou, ao menos, os operadores do Direito teriam de verificar a veracidade de tudo o que eles dizem. Juízes teriam de se especializar em Medicina, Arquitetura, Engenharia, Meteorologia, Economia e o que mais aparecesse como relevante para o julgamento de um caso concreto. Tal cenário não é factível.

A seguir, os esquemas do argumento, a partir da posição de saber em sua forma mais básica, e o seu subtipo, a partir da opinião do expert (baseados em AS, p. 309/310):

\section{Argumento a partir da posição de saber}

\begin{tabular}{|l|l|}
\hline $\begin{array}{l}\text { Premissa 1 } \\
\text { Garantia) }\end{array}$ & $\begin{array}{l}\text { Geralmente se uma fonte } a \text { está em posição de saber em um domínio S que } \\
\text { contém a proposição A, e } a \text { enuncia que A é verdadeira (falsa), então A é } \\
\text { verdadeira (falsa). (generalização derrotável) }\end{array}$ \\
\hline $\begin{array}{l}\text { Premissa 2 } \\
\text { (Posição } \quad d e \\
\text { Saber) }\end{array}$ & $\begin{array}{l}\text { A fonte } a \text { está em posição de saber em um domínio S que contém a } \\
\text { proposição A. (ordinária) }\end{array}$ \\
\hline $\begin{array}{l}\text { Premissa 3 } \\
(\text { Asserção) }\end{array}$ & a enuncia que a proposição A é verdadeira (falsa). (ordinária) \\
\hline Conclusão & A é verdadeiro (falso). \\
\hline
\end{tabular}

\section{Questões Críticas}

\begin{tabular}{|l|l|}
\hline Questão 1 & $a$ é uma fonte pessoalmente confiável/honesta? (exceção) \\
\hline Questão 2 & a está realmente em posição de saber se A é verdadeira (falsa)? \\
\hline Questão 3 & a realmente disse que A é verdadeira (falsa)? \\
\hline
\end{tabular}

\section{Argumento a partir da Opinião do Expert}

\begin{tabular}{|l|l|}
\hline $\begin{array}{l}\text { Premissa 1 } \\
\text { Garantia })\end{array}$ & $\begin{array}{l}\text { Geralmente se uma fonte E é um expert na área do conhecimento S, que } \\
\text { contém a proposição A, e E enuncia que A é verdadeira (falsa), então A é } \\
\text { verdadeira (falsa). (generalização derrotável) }\end{array}$ \\
\hline Premissa 2 & $\begin{array}{l}\text { A fonte E é um expert na área do conhecimento S, que contém a } \\
\text { proposição A. }\end{array}$ \\
\hline Premissa 3 & E enuncia que a proposição A é verdadeira (falsa). \\
\hline
\end{tabular}




\begin{tabular}{|l|l|}
\hline Conclusão & A é verdadeiro (falso). \\
\hline & \multicolumn{1}{c|}{ Questões Críticas } \\
\hline Questão 1 & Expertise - Qual é a credibilidade de E como expert? \\
\hline Questão 2 & Campo - E é um expert na área de conhecimento da qual A faz parte? \\
\hline Questão 3 & Opinião - O que E disse que implica A? \\
\hline Questão 4 & Confiança - E é pessoalmente confiável como fonte? \\
\hline Questão 5 & Consistência - A é consistente com o que outros experts dizem? \\
\hline Questão 6 & Evidência de Base - A assertiva de E é baseada em evidências? \\
\hline
\end{tabular}

A garantia dos esquemas do argumento acima são generalizações derrotáveis, pois, mesmo que todas as premissas sejam verdadeiras, e que as questões críticas sejam respondidas adequadamente, existe a possibilidade de a fonte que está em posição de saber ou do expert estarem equivocados.

Importante notar que esse tipo de argumento costuma ser usado tanto para questões de fato, quanto para questões de direito. Ainda que os operadores do Direito possam usar esse esquema com muito proveito no primeiro caso, para as questões de direito sua utilização pode ser bastante criticável. Afinal, pode indicar que o operador do Direito não esteja enfrentando a questão que deveria debater e esteja deixando de construir a justificativa para suas alegações. $\mathrm{O}$ argumento a partir da posição de saber e da opinião do expert é importante em contextos nos quais os participantes de diálogo não tenham informação sobre alguma premissa fática que dê base ao seu raciocínio e não disponham de tempo nem de recursos para investigá-la a fundo. Geralmente não é o tipo de argumento adequado para opinar diretamente sobre a questão central do diálogo, pois ele empobrece a discussão.

Observe-se, no entanto, que, por vezes, as "autoridades" jurídico-doutrinárias podem contribuir para solucionar questões de fato. Em decisões da Organização Mundial do Comércio, por exemplo, quando os julgadores desejam saber qual a interpretação que geralmente se dá a determinada regra em um sistema jurídico, eles consultam doutrinadores. Há muitos livros de comentários que indicam a interpretação jurisprudencial majoritária ou que são seguidos por muitos operadores. Doutrinadores podem servir de 
termômetro da interpretação que geralmente se faz e das razões que geralmente se oferecem, mesmo que a sua "posição de saber" não deva servir para emprestar força aos argumentos que atuam diretamente sobre a tese central debatida no diálogo.

\section{II.2.A.iii Pragmático e Objetivo da Lei}

O argumento pragmático é aquele que atribui a uma tese ou fato o valor, ou parte do valor, de suas consequências. Em Direito o argumento pragmático é especialmente importante nos casos em que haja dúvida sobre a melhor intepretação dentre duas ou mais alternativas possíveis. Analisar as consequências, muitas vezes, permite que se justifique a decisão.

Abaixo, o esquema do argumento pragmático, estudado no Capítulo 1, Seção I.2.A.i:

\section{Argumento Pragmático (Positivo)}

\begin{tabular}{|l|l|}
\hline $\begin{array}{l}\text { Premissa 1 } \\
\text { (Garantia) }\end{array}$ & $\begin{array}{l}\text { Geralmente se alguma coisa A gera alguma coisa boa X, então A deve ser } \\
\text { realizado. (generalização derrotável) }\end{array}$ \\
\hline $\begin{array}{l}\text { Premissa 2 } \\
\text { (Causal) }\end{array}$ & $\begin{array}{l}\text { Se A for realizado, então X (certamente, provavelmente, plausivelmente) } \\
\text { ocorrerá. (ordinária) }\end{array}$ \\
\hline $\begin{array}{l}\text { Premissa 3 } \\
\text { (Valorativa) }\end{array}$ & X é algo bom. (ordinária) \\
\hline Conclusão & A deve ser realizado. \\
\hline
\end{tabular}

\section{Questões Críticas}

\begin{tabular}{|l|l|}
\hline Questão 1 & $\begin{array}{l}\text { Se A for realizado, X (certamente, provavelmente, plausivelmente) } \\
\text { ocorrerá? } \\
\text { • Há certeza? } \\
\text { • Quão provável é a ocorrência de X? } \\
\text { • Quão plausível é a ocorrência de X? }\end{array}$ \\
& (Ver esquema do argumento da relação causa / consequência) \\
\hline Questão 2 & X é algo bom? \\
& - Sim ou não?
\end{tabular}




\begin{tabular}{|l|l|}
\hline & \multicolumn{1}{|c|}{ Quão bom é X? } \\
& (Ver esquema do argumento da valoração) \\
\hline Questão 3 & $\begin{array}{l}\text { Há outras consequências opostas (más em oposição a boas, por exemplo) } \\
\text { que deveriam ser consideradas? }\end{array}$ \\
\hline
\end{tabular}

O esquema do argumento apresenta uma generalização derrotável, pois, ainda que haja uma consequência positiva ou negativa em um sentido, pode haver outras no sentido oposto (questão crítica 3) de valor igual ou maior. Assim, a conclusão não pode ser necessária.

Em Direito os valores relevantes a serem protegidos podem ser encontrados no próprio ordenamento jurídico. Com efeito, uma compreensão adequada do Direito depende da compreensão dos valores que as normas jurídicas protegem e dos objetivos específicos que elas perseguem.

Assim, o argumento pragmático em Direito pode ser encontrado de uma forma peculiar, que é o argumento pelo objetivo da Lei ou pela intenção do legislador (entendendo-se que Lei pode englobar a Constituição, lei, orientação jurisprudencial, instituto, norma etc.), e segue o esquema abaixo:

\section{Argumento pelo Objetivo da Lei / Intenção do Legislador}

\begin{tabular}{|l|l|}
\hline $\begin{array}{l}\text { Premissa 1 } \\
\text { (Garantia) }\end{array}$ & $\begin{array}{l}\text { Geralmente se a Lei tem por objetivo proteger ou alcançar X e a decisão D } \\
\text { protege ou alcança X, então a decisão D deve ser tomada. (generalização } \\
\text { derrotável) }\end{array}$ \\
\hline $\begin{array}{l}\text { Premissa 2 } \\
\text { (Objetivo) }\end{array}$ & A Lei tem por objetivo proteger ou alcançar X. (ordinária) \\
\hline $\begin{array}{l}\text { Premissa 3 } \\
\text { (Decisão) }\end{array}$ & A decisão D protege ou alcança X. (ordinária) \\
\hline Conclusão & Deve ser tomada a decisão D. \\
\hline
\end{tabular}




\section{Questões Críticas}

\begin{tabular}{|l|l|}
\hline Questão 1 & A Lei realmente tem por objetivo proteger ou alcançar X? \\
\hline Questão 2 & $\begin{array}{l}\text { A decisão D realmente protege ou alcança X? Em que medida se dá essa } \\
\text { proteção? } \\
\text { (Ver esquema do argumento da relação causa / consequência) } \\
\text { (Ver esquema do argumento da valoração) }\end{array}$ \\
\hline Questão 3 & $\begin{array}{l}\text { Há outros valores ou objetivos Y protegidos pela Lei e afetados } \\
\text { negativamente pela decisão D? } \\
\text { Em caso positivo, há outra decisão D1 que possa assegurar igual } \\
\text { proteção a X sem afetar negativamente Y? } \\
\text { Em que medida Y é afetado? } \\
\text { (Ver esquema do argumento da relação causa / consequência) } \\
\text { (Ver esquema do argumento da valoração) }\end{array}$ \\
\hline
\end{tabular}

A garantia permanece sendo uma generalização derrotável, pelos mesmos motivos que no esquema do argumento pragmático básico, isto é, a possibilidade de outros valores atuarem no sentido oposto. Como se pode verificar no Argumento pelo Objetivo da Lei, a discussão sobre $\mathrm{X}$ ser algo bom é substituída pela discussão para determinar se $\mathrm{X}$ é o objetivo ou não da Lei. A questão crítica pertinente segue essa mudança e deixa de perguntar se X é algo bom, para questionar se esse é realmente o objetivo da Lei ou a intenção do legislador.

A discussão para saber se $\mathrm{X}$ ocorrerá se transforma na discussão para saber se a decisão concreta $\mathrm{D}$ protege ou alcança $\mathrm{X}$. A questão crítica acompanha a mudança, e os problemas de causalidade do argumento pragmático também estão aqui. No entanto, também se passa a discutir quanto a decisão $D$ protege ou alcança $X$, pois pode haver outras decisões possíveis que protejam $\mathrm{X}$ melhor. Pode ser também que o valor alcançado por $\mathrm{X}$ tenha de ser confrontado com o quanto a mesma decisão $\mathrm{D}$ afeta negativamente outro valor importante Y (questão crítica 3). 
As questões críticas 2 e 3 englobam as discussões referentes ao famoso princípio da proporcionalidade, aplicado no conflito entre dois princípios (entendidos como mandamentos de otimização/maximização de um valor protegido pelo Direito $)^{47}$. O princípio da proporcionalidade diz que nesses casos deve-se questionar: (a) a adequação de uma medida ao seu fim (questão crítica 2); (b) a necessidade da imposição de uma medida para se atingir um fim, ou seja, se não há outro meio menos gravoso de se atingir a mesma finalidade (questão crítica 3); (c) a proporcionalidade, ou seja, a ponderação de dois valores, considerando quanto um valor foi afetado positivamente, e quanto o outro foi afetado negativamente (para isso a valoração prevista nas questões críticas 2 e 3).

\section{II.2.B Argumentos de Operacionalização - Exceção}

Um dos expedientes mais corriqueiros da argumentação jurídica é defender que a norma invocada pela outra parte não deve ser aplicada no caso concreto porque falta uma condição (positiva ou negativa) para que se produza a consequência desejada.

Por vezes a discussão é de saber se a condição realmente ocorreu no caso concreto. O Promotor Público defende que deve ser aplicada a norma "Se ficar provado que uma pessoa matou outra pessoa, então a primeira será punida com pena de reclusão de seis a vinte anos" (Se A, então X) —, pois Sócrates matou Tostão (A é o caso). O advogado de defesa alega que não restou provado que Sócrates tenha matado Tostão (A não é o caso).

Noutras vezes o problema é de dizer que a norma invocada na verdade está incompleta; faltam condições para que seja aplicada. $\mathrm{O}$ advogado de defesa pode alegar que Sócrates agiu em legítima defesa. Se a legítima defesa exclui necessariamente o crime, uma das condições necessárias para que alguém possa ser punido por homicídio é que não tenha agido em legítima defesa. Constrói-se assim uma exceção à regra. Essas exceções

\footnotetext{
${ }^{47}$ Para discussões sobre o conflito de princípios veja-se o famoso livro de Robert Alexy ALEXY, Robert. Teoria dos Direitos Fundamentais. $2^{\text {a }}$ Ed. São Paulo: Malheiros, 2011. Para maiores esclarecimentos sobre o tema ver SILVA, Virgílio Afonso da. Princípios e regras: mitos e equívocos acerca de uma distinção. Revista Latino-Americana de Estudos Constitucionais 1 (2003), p. 607-630; e SILVA, Virgílio Afonso da. Ponderação e objetividade na interpretação constitucional in MACEDO JR., Ronaldo Porto e BARBIERI, Catarina Helena Cortada (Orgs.) Direito e interpretação: racionalidades e instituições. São Paulo: Direito GV/Saraiva, 2011, p. 363-380.
} 
podem ser vistas como condições relevantes que não foram abordadas pelo argumento original.

Como este tipo de argumento é muito comum, o esquema de operacionalização construído abaixo será dedicado a ele. Verificaram-se as possibilidades de todos os tipos de condições (absoluta, necessária, suficiente e contributiva) e os impactos nas conclusões (necessárias ou derrotáveis).

\section{Exceção (Argumento de Operacionalização de Condições)}

\begin{tabular}{|l|l|}
\hline $\begin{array}{l}\text { Premissa 1 } \\
\text { (Condição) }\end{array}$ & $\begin{array}{l}\text { A norma N pressupõe a condição (absoluta, necessária, suficiente, } \\
\text { contributiva) X para a consequência Y. (ordinária) }\end{array}$ \\
\hline $\begin{array}{l}\text { Premissa 2 } \\
\text { (Presença) }\end{array}$ & A condição X está /não está presente no caso. (ordinária) \\
\hline Conclusão & Então (necessariamente, plausivelmente) Y / não-Y. \\
\hline
\end{tabular}

\begin{tabular}{|l|l|}
\hline \multicolumn{2}{|c|}{ Questões Críticas } \\
\hline Questão 1 & A norma N realmente pressupõe a condição X para a consequência Y? \\
\hline Questão 2 & A condição X realmente está/não está presente no caso? \\
\hline $\begin{array}{l}\text { Observação } \\
\text { conforme } \\
\text { tipo } \\
\text { condição }\end{array}$ & $\begin{array}{l}\text { Condição Absoluta } \\
\text { X: generalização absoluta / conclusão necessária positiva } \\
\text {-X: generalização absoluta / conclusão necessária negativa } \\
\text { Condição Necessária }\end{array}$ \\
& $\begin{array}{l}\text { X: generalização derrotável / conclusão derrotável positiva } \\
-X: \text { generalização absoluta / conclusão necessária negativa } \\
\text { Condição Suficiente } \\
\text { X: generalização absoluta / conclusão necessária positiva } \\
-X: \text { generalização derrotável / conclusão derrotável negativa } \\
\text { Condição Contributiva } \\
\text { X: generalização derrotável / conclusão derrotável positiva } \\
-X: \text { generalização derrotável / conclusão derrotável negativa }\end{array}$ \\
\hline
\end{tabular}


Algumas observações são importantes. O ônus da prova associado à Premissa 1 é ordinário. Isso significa que algum argumento de justificação terá de ser oferecido para sustentar a condição, seja a aplicação de uma regra ou o objetivo da lei. No caso da legítima defesa, por exemplo, o advogado de defesa teria que aplicar o Art. 23, II do Código Penal. Ademais, as condições contributivas podem ser cumulativas e apresentar "pesos" diferentes a contribuir para uma conclusão.

\section{II.2.C Classificação de Esquemas da Argumentação Jurídica}

A partir das seções precedentes, podemos construir a seguinte classificação de esquemas:

\section{$\rightarrow \underline{\text { Argumentos de Justificação }}$}

- Tradição

- Tradição Jurídica

- Aplicação de Norma Jurídica

- Posição de Saber

- Opinião do Expert

- Pragmático

- Objetivo da Lei

\section{$\rightarrow \underline{\text { Argumentos de Operacionalização }}$}

- Exceção Jurídica (operacionalização de condições)

O conjunto de esquemas apresentado são adaptações da teoria da argumentação às peculiaridades da argumentação jurídica que, apesar de simples, podem contribuir para aclarar o raciocínio jurídico. Como dito na Introdução, os esquemas do argumento e a teoria da argumentação não servem para revolucionar a argumentação, mas para esclarecer e precisar, permitindo um incremento de qualidade nas discussões. Os argumentos do caso prático estudado no Capítulo 3 foram estudados tendo-se em vista esse conjunto de esquemas. 


\section{SECÃO III.3 DIAGRAMAČ̃̃O DE ARGUMENTOS NO DIREITO}

As convenções que adotamos para a diagramação de argumentos levam em consideração os diferentes graus de detalhe que um mapa argumentativo pode apresentar e buscam ser o mais simples possível, tendo sido modeladas para diagramar um diálogo entre duas partes. As proposições podem ser escritas por extenso no diagrama ou representadas por símbolos, devendo ser o diagrama acompanhado de legenda discriminando o conteúdo das proposições. Essa segunda opção é mais indicada para os casos em que a discussão a ser representada é grande, para facilitar a visualização do mapa.

A seguir a representação de cada elemento:

Partes: Cada elemento representativo será preenchido com uma cor, de acordo com a Parte responsável por enunciá-lo. Escolhemos branco e cinza para distinguir as partes.

Proposicão: Representada por um círculo. As proposições são numeradas P1, P2, P3, (...), na ordem de sua apresentação no diálogo. A numeração é independente para cada parte. A cor que preenche o círculo indica a parte.

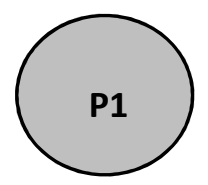

Conclusões - Para diferenciá-las das proposições que sustentam o argumento, as conclusões podem ser representadas por C1, C2, C3, (...), de acordo com a conveniência do analista.

Argumento: Representado por um quadrado e uma seta que aponta para a conclusão. As proposições podem ser agrupadas entre colchetes, indicando que pertencem a um argumento. Os argumentos podem ser representados por um nome dado pelo analista, ou por letras maiúsculas em ordem alfabética, $A, B, C$, (...). A cor que preenche o quadrado e a seta indica a parte. Por conta de limitações nas ferramentas de desenho do computador, a seta preta corresponde à parte branca e a seta cinza à parte cinza. 

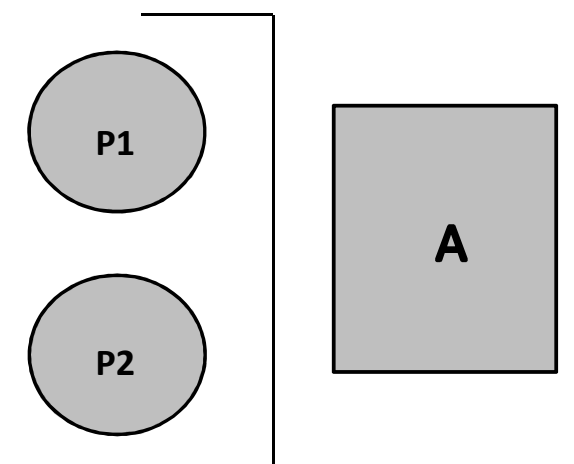

Proposições Complementares/Opostas - Para representar os ataques a proposições por meio de um argumento cuja conclusão seja a proposição oposta ( “p” ” “-p”), basta que a cor da seta seja diferente da cor da proposição para a qual a seta aponta. (Regra utilizada para diagramar ataques às premissas e às conclusões)

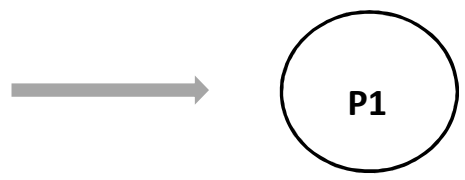

Exceções / Corte do Link Inferencial - Para representar ataques que cortam o link inferencial (exceções) a seta deve apontar para algum trecho da seta do argumento atacado. Caso o diagrama esteja detalhando também as proposições, a seta sairá da conclusão do argumento que corta o link inferencial.

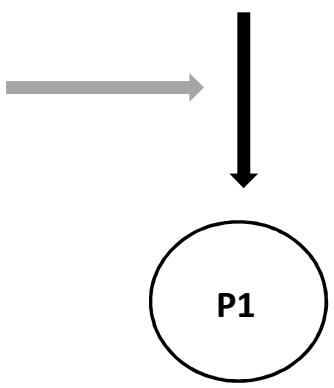

Neste diagrama simplificado não estão representadas informações sobre o ônus da prova associado às premissas, nem se o tipo de argumento é dedutivo, indutivo ou derrotável, o que mudaria o sustento da conclusão. Tampouco estão informados o eventual grau (seja percentual ou não) de sustento à conclusão, o esquema de argumento em que cada argumento se baseia ou o status da premissa. Essas informações podem ser inseridas nas eventuais legendas que discriminam argumentos e proposições. 
A vantagem da simplificação é a fácil visualização e compreensão do percurso do debate, motivo pelo qual adotamos essas convenções, que serão utilizadas no Capítulo 3. Nada impede que as convenções expostas sejam complementadas para representarem as informações mencionadas acima quando conveniente. Por exemplo, setas diferentes (pontilhadas ou mais largas) poderiam representar a necessariedade, probabilidade ou plausibilidade da conclusão, revelando ainda o tipo de argumento. $\mathrm{O}$ grau de probabilidade ou plausibilidade pode tornar-se um número ou um símbolo do lado da seta. O ônus da prova associado às premissas pode se converter em um símbolo adicional nos círculos que representam as proposições. 


\section{CAPÍTULO III \\ O CASO ARAGUAIA}

De 1964 a 1985 o Brasil foi governado pelo Regime Militar. Nesse período, as possibilidades de ação da oposição política foram controladas pelo governo. As ideologias de esquerda eram vistas como uma ameaça à segurança nacional e, por consequência, aqueles que as defendiam também eram ameaças à segurança nacional. Tais ameaças eram reprimidas.

A repressão atingiu limites extremos, chegando à prática de homicídios, torturas e aos chamados "desaparecimentos forçados". De outro lado, a oposição política pegou em armas e iniciou guerrilhas, dentre elas, a famosa "Guerrilha do Araguaia".

Em 1979, no período de "abertura" do Regime Militar, foi promulgada a Lei de Anistia (Lei 6.683), que anistiava a oposição política pelos crimes cometidos e, talvez (pois esse ponto é objeto de controvérsia), os militares, incluindo torturadores e responsáveis por "desaparecimentos forçados".

Em 1995 foi promulgada a Lei 9.140, que reconheceu como mortos os desaparecidos políticos e estabeleceu indenização para seus familiares, a ser paga pelo Estado. Em 2002, foi promulgada a Lei do Regime de Anistiado Político (10.559), que criou a figura do "Anistiado Político" e estabeleceu novas indenizações a serem pagas pelo Estado.

Em 2008 a OAB ajuizou a Arguição de Descumprimento de Preceito Fundamental 153/DF, buscando que fosse dada à Lei de Anistia interpretação conforme a Constituição Federal, possibilitando a persecução penal dos responsáveis por homicídios, torturas e desaparecimentos forçados. Contudo, em 2010 a ADPF 153 foi rejeitada por 7 a 2, sendo o voto do Ministro Relator Eros Grau o maior responsável pelo resultado. 
Em síntese, o argumento vencedor foi o de que historicamente a intenção da Lei de Anistia foi abranger todos, inclusive os militares, devido ao acordo político que houve na época. A Lei de Anistia seria uma "lei-medida" que teve todos os seus efeitos esgotados no momento em que entrou em vigência, não sendo atingida pela nova Constituição Federal de 1988 e não podendo ser revista momento pelo Poder Judiciário, sob pena de violação da separação dos poderes.

Apesar da decisão do STF, em dezembro de 2010 a Corte Interamericana de Direitos Humanos, CIDH, analisando o caso da "Guerrilha do Araguaia", declarou, com base em sua jurisprudência consolidada, que não seria reconhecida validade à "autoanistia" intentada pelo governo brasileiro.

No Brasil, o Ministério Público Federal ofereceu denúncia contra militares que participaram dos desaparecimentos forçados, alegando que tais crimes, pelo seu caráter permanente, não estariam abrangidos pela Lei de Anistia. Desse modo, continua o MPF, a condenação penal estaria de acordo com a decisão do STF e com a decisão da CIDH $^{48}$.

Paralelamente a todos esses acontecimentos, esforços foram feitos para buscar a verdade sobre o que aconteceu no regime militar e preservar a memória das torturas e desaparecimentos forçados. Como ponto máximo da busca pela verdade histórica e pela preservação da memória, recentemente foi instituída a Comissão da Verdade pela Lei 12.528/2011. Por fim, várias ações foram ajuizadas buscando a responsabilização civil do Estado e dos torturadores, e há até uma ação do Ministério Público buscando regresso contra os torturadores pelas indenizações pagas às vítimas ${ }^{49}$.

Diante do cenário apresentado, discute-se qual a melhor maneira de responsabilizar o Estado e os próprios militares, nos âmbitos administrativo, penal e civil. Debate-se ainda a melhor maneira de descobrir a verdade sobre o ocorrido e de preservar a sua memória.

\footnotetext{
${ }^{48}$ Por exemplo, ver a denúncia oferecida pelo Ministério Público Federal contra o Coronel Carlos Alberto Brilhante Ustra e Dirceu Gravina, processo no 0004204-32.2012.4.03.6181, em trâmite perante a Justiça Federal de São Paulo, atualmente localizado no Tribunal Regional Federal da $3^{\text {a }}$ Região. Para mais informações, ver Apêndice III.

${ }^{49}$ Processo $n^{\circ}$ 0011414-28.2008.4.03.6100, em trâmite perante a Justiça Federal de São Paulo, atualmente localizado no Tribunal Regional Federal da $3^{\text {a }}$ Região. Para mais informações, ver Apêndice III.
} 
Na primeira seção deste Capítulo 3 apresentaremos uma breve história do Regime Militar, do Caso Araguaia e do processo político de Anistia. Na segunda seção, apresentaremos um Mapa Argumentativo dos debates que se instauraram.

\section{SECÃO III.1 UMA BREVÍSSIMA HISTÓRIA DO REGIME MILITAR, TORTURAS, ASSASSINATOS E DESAPARECIMENTOS POLÍTICOS}

A história do regime militar, das torturas, assassinatos e desaparecimentos políticos é bastante conhecida e já foi contada de maneira detalhada em diversas obras. Nesse trabalho nos limitaremos a expor apenas o essencial para se entender o que aconteceu, fazendo o recorte de acordo com aquilo que pode ser juridicamente relevante. Ou seja, essa história, tal qual será contada aqui, muito se assemelha à exposição dos fatos realizada em uma peça jurídica (seja uma petição inicial, uma contestação ou o voto de um juiz). Para poder realizar essa corte foi essencial conduzir duas pesquisas, a princípio paralelas, que se tornaram mais e mais conectadas ao longo do seu desenvolvimento.

De um lado, uma pesquisa histórica sobre o que aconteceu em detalhes. Essa pesquisa buscou compreender, primeiro, o regime militar e seu funcionamento. Quem foram os atores políticos que orquestraram a tomada do poder pelos militares, quais eram seus objetivos, qual foi a sua justificativa. Quem estava na oposição ao governo, como eles se opunham. Como se estruturava e funcionava o aparato repressivo, quais eram as atividades alvo da repressão, como se deu a repressão ao longo do regime. Qual era o arcabouço jurídico que justificava legalmente a repressão, como ele operava na prática. Qual era o perfil dos assassinos e torturadores, qual era o perfil dos assassinados, torturados e desaparecidos, como aconteciam os assassinatos, torturas e desaparecimentos. Quem eram os guerrilheiros, como eles lutaram contra o governo, como foi a resposta dos militares.

Em um segundo momento, a pesquisa histórica buscou compreender o processo político de anistia em seu sentido amplo, ou seja, todo o debate político sobre a responsabilização do Estado e dos militares pelos assassinatos, torturas e desaparecimentos. Quais foram os principais marcos legislativos sobre o assunto, como se deu o debate antes e depois da edição de tais diplomas. Como as previsões legislativas 
efetivamente operaram na prática. Como as cortes decidiram sobre o assunto, quais os principais processos e casos em andamento, ou julgados, que discutem essas responsabilidades. Como o executivo participou desse debate, como os militares reagiram aos sucessivos diplomas normativos e às decisões do governo. Importante frisar que esse debate continua até hoje e, de um modo ou de outro, nunca deixou de estar presente na agenda política do país.

De outro lado, uma pesquisa sobre os debates jurídicos que se instauraram em virtude dos assassinatos, torturas e desaparecimentos forçados. A discussão sobre a responsabilidade do Estado e dos Militares em seus âmbitos civil, penal e administrativo. A questão acerca do direito à verdade sobre o que ocorreu no período e da preservação da memória do regime militar. Claro que esses debates fazem referência aos marcos legislativos, aos processos judiciais e aos debates políticos compreendidos pela pesquisa histórica. Como não poderia deixar de ser, a conexão entre os fatos e o direito se acentuou ao longo da pesquisa.

Apesar da conexão, é importante que as duas pesquisas tenham começado e sido conduzidas relativamente em separado. Conhecer os fatos em detalhe permite avaliar de maneira mais crítica as premissas fáticas nas quais se baseiam os raciocínios jurídicos, bem como perceber aspectos importantes que potencialmente não estão contemplados nos debates jurídicos. Em sentido oposto, é o conhecimento do marco jurídico que permite selecionar os elementos fáticos relevantes para a discussão do problema. Mas o Direito por vezes deve ser utilizado antes como um filtro do que como uma lente. Primeiro conhecer os fatos e depois separar o que é importante, com as devidas justificativas, e não desde logo começar a procurar fatos para provar nossas hipóteses. Apesar de essa separação ser sempre relativa e difícil de fazer, a ideia geral é de que devemos estar abertos para novas descobertas e novos argumentos que geralmente surgem de um olhar curioso dos fatos.

Entendemos importante facilitar ao leitor (e potencial pesquisador) o acesso ao material de referência que tivemos a oportunidade de levantar e estudar. Assim, elaboramos o Apêndice III, que conta com as referências organizadas de nosso material de pesquisa. Primeiro, separamos os principais relatórios, dossiês e obras de referência que trazem estudos detalhados dos fatos. Segundo, organizamos por ordem cronológica todas 
as notícias que selecionamos relacionadas aos debates do processo político de anistia a partir de 1979. Todas elas podem ser encontradas na internet. Terceiro, elaboramos listas de diplomas normativos relevantes para análise do caso. Quarto, apresentamos uma relação de alguns processos judiciais que estudamos, acompanhados de um pequeno resumo e informações sobre a sua situação e localização atuais. Por fim, selecionamos alguns filmes e documentários sobre o tema.

Por fim, ao apresentarmos a narrativa fática a seguir, tentamos, na medida do possível, atingir o máximo de imparcialidade. As fontes e obras de referência mais conhecidas e acessíveis costumam contar a história enfatizando o caráter repressivo e os excessos do regime militar. Esse tipo de fonte também pode ser encontrado em maior número. São raríssimos os livros que contam a história do ponto de vista dos militares.

Assim, com o intuito de satisfazer o ideal almejado de imparcialidade, algumas medidas foram tomadas. Sempre que possível foi feita a consulta às fontes citadas pelas obras de referência, principalmente notícias, processos e diplomas legislativos. As obras de referência foram lidas com cuidado e desconfiança em relação às interpretações oferecidas. Também foi consultada a obra A Verdade Sufocada: a história que a esquerda não quer que o Brasil conheça, escrita pelo Coronel Reformado Carlos Alberto Brilhante Ustra ${ }^{50}$, comandante do DOI/CODI/II Exército de 29/09/1970 a 23/01/1974, notoriamente acusado de torturas e principal alvo de processos cíveis e criminais que buscam responsabilizar pessoalmente militares. Todos têm direito de se defender. Todo diálogo tem dois lados.

\section{Seção III.1.A O Regime Militar: Repressão}

A descrição a seguir foi feita principalmente com base no projeto Brasil: Nunca Mais, de 1985, um marco no estudo da repressão durante o Regime Militar. O famoso livro Brasil: Nunca Mais (também conhecido como "Projeto B") é um resumo em forma de reportagem do chamado "Projeto A", um extenso relatório de milhares de páginas sobre a

\footnotetext{
${ }^{50}$ USTRA, Carlos Alberto Brilhante. A Verdade Sufocada: a história que a esquerda não quer que o Brasil conheça. $8^{\text {a }}$ Ed. Brasília: Editora Ser, 2012.
} 
repressão até 1979. A íntegra do Projeto A e do Projeto B pode ser encontrada na internet no site $\underline{\text { www.armazemmemoria.com.br }}{ }^{51}$.

O projeto de pesquisa foi elaborado a partir da análise de processos ${ }^{52}$ da Justiça Militar ajuizados contra a oposição. O objetivo era evitar críticas a eventual viés dos pesquisadores. O período de pesquisa foi limitado até 1979 para garantir distanciamento histórico-temporal dos fatos, valendo lembrar que a Lei de Anistia é de 1979. Nas próximas páginas usaremos BNM para fazer referência ao Projeto B.

Preliminarmente, para mostrarmos a dimensão do ocorrido, alguns números são importantes. Eles foram obtidos pelo projeto Brasil: Nunca Mais a partir da análise de 695 processos que tramitaram na Justiça Militar buscando a punição de pessoas por violações à Lei de Segurança Nacional ${ }^{53}$. Nestes documentos foram encontrados 7.367 nomes de réus, sendo que uma parte desses nomes é de pessoas que responderam a mais de um processo (BNM, p.83).

A acusação mais comum era a militância em organização partidária proibida, com 4.935 casos. Em seguida, a participação em ação violenta ou armada, 1.464 casos. O Projeto B destaca ainda: participação em cargos do governo deposto em 1964 ou a simples identificação política com ele, com 484 casos; a manifestação de ideias por meios legais (imprensa, aulas, sermões, etc.), com 145 casos; e, por fim, a manifestação de ideias por meios artísticos, com 18 casos (BNM, p.84/85).

Segundo o BNM, o estudo da distribuição das acusações ao longo do tempo traz conclusões interessantes. Verifica-se que desde datas próximas a 1964, os processos derivavam de Inquéritos Policiais Militares (IPM's) contra movimento sindical, estudantil

\footnotetext{
${ }^{51}$ Após entrar no site basta clicar em "Brasil Nunca Mais" na lista de "Centros de Referência Virtual". O Projeto A pode ser encontrado na aba "Documentos" enquanto o Projeto B está disponível em "Biblioteca" junto de outros textos e livros sobre o período.

${ }^{52}$ Segundo informações do BNM, foram analisados mais de 707 processos completos e outros incompletos. Esse não é todo o universo de processos, mas foram as cópias que os pesquisadores conseguiram obter. ARQUIDIOCESE DE SÃO PAULO. Brasil: Nunca Mais. 39ª Ed. Petrópolis: Vozes, 2011, p.20

${ }^{53}$ A Lei de Segurança Nacional foi reeditada e alterada várias vezes desde a sua primeira versão, o DecretoLei 314 de 13 de março de 1967. Para um histórico das suas versões consultar o Apêndice III deste trabalho.
} 
e órgãos de representação da sociedade civil. As acusações eram majoritariamente de “participação em entidades ou movimentos de massa". A partir de 1969, época da edição do Ato Institucional $n^{\circ} 5$ e da alteração da Constituição Federal, a acusação predominante passou a ser "militância em organização partidária clandestina", crescendo intensamente no governo Médici (1969-1974) as acusações por "ação armada" e por "manifestação de ideias por meios não regulares" (BNM, p. 85) (Projeto A, Tomo III, p.4) ( $^{54}$.

De acordo com o BNM, os dados corroboram a tese de que a clandestinidade e os métodos violentos de oposição foram uma resposta ao endurecimento do regime militar, ou seja, ao aumento da repressão e fechamento dos canais de oposição política (BNM, p.85). A proposição de que a oposição armada e violenta foi uma resposta ao endurecimento do regime militar merece destaque, pois será utilizada nos debates adiante. Trata-se de uma parte da resposta oferecida pelo BNM ao argumento dos militares de que o endurecimento e a repressão violenta foram uma resposta à violência dos grupos de esquerda (BNM, p.87). Anote-se que Eduardo Seabra Fagundes, presidente da OAB à época da Lei de Anistia, defendia a mesma proposição. ${ }^{55}$

A versão oferecida pelo Coronel Ustra é diferente. Para ele, o endurecimento foi uma resposta aos atos violentos perpetrados pelos guerrilheiros, principalmente no cenário urbano. Escreve o Coronel "Não queríamos a luta armada, não a desejamos, não a procuramos, nem estávamos preparados para ela. Lamentamos a morte de jovens que foram iludidos, fanatizados e usados por experientes militantes comunistas" (USTRA, p.321).

De acordo com o coronel, o marco inicial da luta armada no Brasil foi um atentado à bomba que ocorreu no Aeroporto de Guararapes, em Recife/PE, em 25 de julho de 1966, deixando dois mortos, o jornalista Edson Régis de Carvalho e o almirante reformado Nelson Gomes Fernandes, e mais treze pessoas gravemente feridas, havendo casos de amputação. Parte dos atingidos foi de civis, incluindo um menino de seis anos de idade.

\footnotetext{
${ }^{54}$ Os quadros com a distribuição cronológica dos processos podem ser encontrados no Projeto A, Tomo II, Vol. 1, p.246/249.

55 VEJA. Anistia? Só restrita... Edição 554, 18 de abril de 1979, p. 20-23. Disponível em http://veja.abril.com.br/acervodigital/. Acesso em 13 de dezembro de 2012, especialmente p.22
} 
Para o coronel, foi responsável pelo atentado a organização Ação Popular (AP), que atuou por meio de Alípio de Freitas e Raimundo Gonçalves Figueiredo. Para suas conclusões, valeu-se o coronel da pesquisa realizada e publicada pelo ex-participante da luta armada Jacob Gorender, no livro Combate nas Trevas (USTRA, p. 154/160).

Assim, segundo o Coronel Ustra, os guerrilheiros eram terroristas, o que demandou medidas e uma legislação excepcional para combatê-los (o endurecimento). Em suas palavras:

"É necessário explicar, porém, que não se consegue combater o terrorismo, amparado nas leis normais, elaboradas para um cidadão comum. Os terroristas não agiam como cidadãos comuns. (...)

O terrorismo só pode ser combatido, eficientemente, com leis especiais (...)

Em nenhum lugar do mundo, terrorismo se combate com flores." (USTRA, p. 317/318)

A pesquisa BNM mostra ainda que o número de processos diminuiu na época da abertura do regime militar, a partir do governo de Ernesto Geisel, em 1974 (Projeto A, Tomo III, p. 1). Contudo, essa redução do número de processos não significa necessariamente que houve um afrouxamento da repressão. Em substituição, o expediente dos desaparecimentos forçados, que será melhor tratado adiante, passou a ser utilizado com maior frequência, tornando-se a regra geral na atuação repressiva. Assim, segundo relatório da Secretaria de Direitos Humanos da Presidência da República, diminuía-se a contradição entre o discurso de abertura e os excessos do regime. ${ }^{56}$

${ }^{56}$ BRASIL. Secretaria Especial dos Direitos Humanos. Comissão Especial sobre Mortos e Desaparecidos Políticos. Direito à Verdade e à Memória. Brasília: Secretaria Especial de Direitos Humanos, 2007, p.27 
Outra estatística importante é a de que nos mesmos 695 processos judiciais há $1.918^{57}$ pessoas que, ao depor judicialmente, declararam ter sido torturadas na fase de inquérito. A distribuição das denúncias ao longo do tempo também se concentra no período de 1969 a 1974, com 1.558 casos (81\%) (BNM, p.85/86). É possível que o número de denúncias seja diferente do de torturas, pois os réus poderiam ter receio de denunciar os torturadores ante o risco de retaliação, e também pode haver réus que mentiram sobre a tortura para tentar desqualificar provas obtidas durante o inquérito, conforme argumenta, por exemplo, o Coronel Ustra (USTRA, p.318).

O BNM destaca ainda que, além dos 7.367 nomes de réus, há 10.034 nomes mencionados apenas na fase de inquérito. Desse total, 6.385 foram indiciados, mas não denunciados, e os restantes 3.649 apareceram apenas como testemunhas ou declarantes. Tais números são importantes, pois como as torturas ocorriam na fase de inquérito, muitos dos indiciados podem ter sido torturados e não terem tido a oportunidade de denunciar a tortura em depoimento judicial. Com efeito, em 100 dos 695 casos, há depoentes que relataram ter presenciado a tortura desses indiciados que não foram denunciados. Além disso, fora dos processos, há muitos relatos de meras testemunhas ou declarantes que foram detidos ou torturados para delatar opositores do regime (BNM, p.86).

Para além dos números, também é importante entender a organização da esquerda e os setores sociais atingidos. Não entraremos em detalhes sobre a história das organizações, nem sobre as diferenças entre as doutrinas políticas que defendiam, mas atentaremos para alguns pontos.

Em primeiro lugar, a oposição ao regime militar não era um bloco organizado. Existiam muitas organizações marxistas com orientações diferentes nos níveis programático (visão da sociedade brasileira e propostas de mudança), estratégico (caminho geral para se obter as transformações) e tático (ações de caráter imediato) (BNM, p.87/88). Havia ainda organizações trotskistas com orientações diferentes quanto ao papel

\footnotetext{
${ }^{57}$ No Projeto A, Tomo III, p. 4 consta que o número seria de 1.843 pessoas. Não sabemos afirmar a razão da diferença de números.
} 
internacional a ser assumido (BNM, p. 106), e organizações que buscavam um "Movimento Nacional Revolucionário", mas sem filiação ideológica marxista ou derivada (BNM, p.107).

Cabe uma nota sobre as organizações de oposição e sua ideologia. Difundiu-se a ideia de que a oposição, especialmente a oposição armada, seria uma "resistência democrática" ao regime. Nada mais equivocado. As ideologias defendidas por essas organizações desprezavam a democracia e propunham outras formas de organização do poder, incluindo Estados totalitários ${ }^{58}$. Por esse motivo, escolhemos usar o termo “oposição" ao regime ao invés de "resistência".

Tantas eram as organizações que o BNM as reuniu em grupos para facilitar a sua apresentação. No livro "Dos filhos deste solo" de Nilmário Miranda e Carlos Tibúrcio, outra obra de referência, os relatos das mortes e desaparecimentos são divididos de acordo com a organização de oposição ao regime a que pertenciam os atingidos. Uma rápida consulta ao sumário deste livro permite verificar a quantidade de grupos que existiam ${ }^{59}$. Citemos alguns, para que se tenha visão mais clara da dispersão da oposição: Partido Comunista Brasileiro (PCB); Partido Comunista do Brasil (PC do B); Ação Libertadora Nacional (ALN); Movimento de Libertação Popular (Molipo); Tendência Leninista (TL); Marx, Mao, Marighella e Guevara (M3G); Frente de Libertação do Nordeste (Flne); Partido Comunista Brasileiro Revolucionário (PCBR); Movimento Revolucionário 8 de Outubro (MR-8); Vanguarda Popular Revolucionária (VPR); Vanguarda Armada Revolucionária - Palmares (VAR-Palmares); Ação Popular (AP); Organização Revolucionária Marxista-Política Operária (Polop); Partido Operário Revolucionário Trotskista (Port); dentre outras ${ }^{60}$.

\footnotetext{
${ }^{58}$ Nesse sentido, ver "Repressão e desenvolvimento: a modernização conservadora" em REIS, Daniel Aarão. Ditadura Militar, esquerdas e sociedade. $3^{\mathrm{a}}$ Ed (e-book). Rio de Janeiro: Jorge Zahar, 2012, p. 12-13

${ }^{59}$ Veja-se ainda na página 31 um gráfico com os partidos e organizações de esquerda de 1961 a 1971, seu nascimento, filiação e encerramento. MIRANDA, Nilmário; TIBÚRCIO, Carlos. Dos filhos deste solo: mortos e desaparecidos políticos durante a ditadura militar, a responsabilidade do Estado. $2^{\mathrm{a}}$ Ed. São Paulo: Perseu Abramo, 2008.

${ }^{60}$ Todas mencionadas no Capítulo 9 do BNM.
} 
Em segundo lugar, muitos dos partidos e organizações que sofreram com a repressão defendiam a transição pacífica para o socialismo e não participaram da luta armada, como, por exemplo, o Partido Comunista Brasileiro (PCB). Parte das organizações que defendiam a luta armada nasceram como dissidências do PCB, como a Ação Libertadora Nacional (ALN) de Carlos Marighella, antigo dirigente do partido. O BNM cita algumas pessoas ligadas ao PCB que sofreram tortura e morreram, ou desapareceram, apesar de não terem participado da luta armada, como David Capistrano da Costa, Luis Inácio Maranhão Filho e o mais conhecido, Vladimir Herzog, morto em outubro de 1975 (BNM, p.89/91).

Para reforçar e aprofundar a ideia de que não apenas os opositores que empreenderam a luta armada sofreram com a repressão, vale aproveitar ainda a análise do BNM sobre os setores sociais atingidos, feita a partir dos processos. Militares e sindicalistas sofreram no começo do Regime, 1964 (constatado por uma concentração de processos nesse ano), evidenciando uma espécie de "cirurgia" para garantir a uniformidade de posição dentro do exército e o funcionamento do modelo econômico imaginado (arrocho salarial e desnacionalização) (BNM, p.122).

De 1968 a 1970 concentram-se os processos sobre estudantes. Após 1964, o movimento estudantil sofreu forte abalo e não se recuperou até 1968, época em que manifestações de estudantes eclodiram em todo o mundo. Com a repressão desses movimentos, ao longo do tempo diminuiu a ação estudantil e aumentou a ação armada (BNM, p.131).

Políticos sofreram originalmente pela aliança com o governo deposto e, mais tarde, pela participação no Movimento Democrático Brasileiro (MDB), o partido de oposição ao governo que, por sua vez, era representado pela Aliança Renovadora Nacional (ARENA). Alguns sofreram por suas ações no cargo político que ocupavam, outros por seus pronunciamentos (BNM, p. 137/143).

Jornalistas foram acusados por qualquer crítica ao governo ou ao estado de coisas, tanto com base na Lei de Imprensa (Lei 5.250/1967) como na Lei de Segurança Nacional. Até mesmo um ideólogo da Lei de Segurança Nacional, frequentemente identificado com o 
regime militar, José de Arimatéia Gomes Cunha, conhecido como "Ari Cunha", foi indiciado e processado. O seu crime teria decorrido de ter denunciado, no Correio Braziliense, o que entendia como um excesso da repressão: as torturas que a presa política grávida Hecilda Mary Veiga Fonteles de Lima teria sofrido no Pelotão de Investigações Criminais - PIC de Brasília (BNM, p. 143/146).

Religiosos também enfrentaram o regime e sofreram com a repressão, apesar de em um primeiro momento terem favorecido a tomada do poder pelos militares, por engajar-se em campanhas anticomunistas. A mudança surgiu a partir do Concílio Vaticano II (19621965), quando a Igreja começou a apoiar setores marginalizados da população. Essa tendência se acentuou ao longo do tempo, principalmente após 1968. Com o endurecimento, a Igreja começou a enfrentar o regime e seus abusos de modo mais direto (BNM, p.146/147).

O tipo de atividade visada pela repressão também ajuda a explicar como todos esses setores sociais e tipos de pessoas foram indiciados, denunciados e, por vezes, torturados, desaparecidos e mortos. O BNM classificou as atividades reprimidas em três grupos: (i) vínculos com o governo constitucional deposto, (ii) propaganda subversiva e (iii) críticas e ataques a autoridades (BNM, p 154). Todos os três grupos compreendem um amplo rol de condutas indiciadas e denunciadas, o que é possibilitado pela vagueza das definições dos crimes contra a segurança nacional e do próprio conceito de segurança nacional ${ }^{61}$.

Diante dessas considerações sobre a organização da esquerda e a repressão, duas proposições relevantes para os debates podem ser extraídas. Primeiro, diante da dispersão da oposição, não se pode considerar a esquerda um bloco único, nem os guerrilheiros como seu "braço armado". Segundo, os excessos da repressão não atingiram somente quem participou da luta armada, mas também quem se opôs ao regime militar de maneira pacífica $^{62}$.

\footnotetext{
${ }^{61}$ Sobre a imprecisão do conceito de segurança nacional e os riscos daí decorrentes, inclusive de violência estatal, ver o estudo clássico do Padre Joseph Comblin, especialmente Capítulo 1, II, B "Segurança Nacional" e Capítulo 5, III, A "O perigoso fascínio do absoluto" e B "Segurança e Violência". COMBLIN, Joseph. A Ideologia da Segurança Nacional: o poder militar na América Latina. Rio de Janeiro: Civilização Brasileira, 1978, p. 54-57 e 225-228.

${ }^{62}$ No mesmo sentido, de maneira expressa: Secretaria Especial dos Direitos Humanos, 2007, p.27
} 


\section{Seção III.1.B O Caso Araguaia}

Esta seção foi escrita principalmente ${ }^{63}$ com base no livro Direito à Memória e à Verdade (doravante referido como "DMA"), editado e publicado em 2007 pela Secretaria de Direitos Humanos da Presidência República, com base no resultado dos trabalhos da Comissão de Mortos e Desaparecidos Políticos, criada pela Lei 9.140/1995. O livro dedicou um capítulo especialmente à Guerrilha do Araguaia pela notoriedade do caso e pela quantidade de mortos e desaparecidos.

A guerrilha do Araguaia aconteceu entre 1972 e 1974, nas proximidades da divisa entre Pará, Maranhão e Tocantins (na época, Goiás), em uma área de cerca de 7.000 Km², compreendendo a região do Bico do Papagaio e os municípios de Marabá/PA e Ximbioá/TO, dentre outras localidades. O objetivo dos guerrilheiros era oferecer resistência armada ao regime militar. Eram cerca de 70 pessoas, a maioria jovens, que atuaram sob a direção do Partido Comunista do Brasil (PC do B) (DMA, p.195).

A guerrilha era composta em sua maior parte de lideranças estudantis que haviam participado de manifestações entre 1967 e 1969 e de pessoas que já haviam sido presas por outras atividades de oposição ao regime. A estratégia adotada pelos guerrilheiros era a da guerra popular prolongada, inspirada na Revolução Chinesa e em Mao Tsé-Tung. A revolução deveria começar pelo campo e promover um cerco às cidades. O primeiro passo dos revolucionários deveria ser instalarem-se em regiões distantes, ganhar confiança da população e recrutar camponeses para lutar pela causa. Os guerrilheiros começaram a se instalar na região ainda da década de 1960 (DMA, p. 195/196).

Já no final da década de 1960, o isolamento da região chamava a atenção do regime militar (pois serviria como local para iniciar um levante contra o governo). A partir de então, os militares realizaram uma série de operações no local, com a finalidade de controlar a situação. Em novembro de 1970, ocorreu a Operação Carajás, uma simulação de manobra de contraguerrilha, com lançamento de bombas e paraquedistas. O objetivo era inibir a presença de militantes e guerrilheiros, mostrando a presença militar. Em agosto de

${ }^{63}$ O Coronel Ustra dedica pouquíssimas páginas de seu livro à Guerrilha do Araguaia, pois não participou de ações militares relacionadas a esse evento. Não pode assim, ser utilizado para a narrativa desta seção. USTRA, 2012, p. 173/175 
1971, tomou parte a Operação Mesopotâmia, para colher informações sobre as atividades no local e prender militantes. Em fevereiro de 1972, desenvolveu-se a Operação Axixá, que buscava mapear os guerrilheiros atuantes (DMA, p.196).

No final de março e começo de abril de 1972, iniciou-se a chamada primeira campanha militar de combate à guerrilha. Cerca de 2.000 homens da Brigada de Infantaria da Selva, parte do Exército e outros reforços, com o apoio de lanchas da Marinha, helicópteros e aviões da Aeronáutica, participaram. Muitos guerrilheiros refugiaram-se na mata, enquanto alguns foram capturados. Nesse momento, a vida dos prisioneiros foi em geral poupada (DMA, p.196).

Relata-se que no primeiro confronto direto, ocorrido em 08 de maio de 1972, houve perdas no exército, com um tenente e um sargento feridos e um cabo morto. Em outro embate, um soldado morto e um sargento ferido. Segundo o DMA, os militares passaram a prender, intimidar, espancar e torturar os moradores e camponeses, por vezes sob a acusação de colaboração com os guerrilheiros, buscando obter maiores informações (DMA, p.197).

Em setembro de 1972 o exército realizou uma nova operação de ampla envergadura, envolvendo um efetivo estimado de 3 a 5 mil homens, denominada Operação Papagaio. Era a segunda campanha militar de combate à guerrilha. Encerrou-se em novembro do mesmo ano, impingindo baixas aos guerrilheiros, mas incapaz de acabar com a guerrilha. Consta que os militares haviam identificado 55 guerrilheiros. Destes, haveria 12 mortos, 6 presos e 37 teriam escapado, mas permaneciam na região. Maurício Grabois teria sido apontado como chefe militar da guerrilha. Por fim, constatou-se que os guerrilheiros dispunham apenas de armamento precário (DMA, p.197).

Entre novembro de 1972 e setembro de 1973 não houve ataques das forças armadas. Os guerrilheiros usaram o tempo para fazer propaganda da causa e tentar recrutar novos combatentes dentre os camponeses. Do outro lado, os militares empreenderam a Operação Sucuri, trabalho de inteligência para obter informações detalhadas sobre as atividades dos guerrilheiros. Cinquenta e três agentes do Centro de Informações do Exército (CIE) participaram da operação disfarçados de agentes da Sucem 
(Superintendência de Combate e Erradicação da Malária), de empregados da empresa de fachada Agropecuária Araguaia, da falsa mineradora DDP e até mesmo de funcionários do Incra (Instituto Nacional de Colonização e Reforma Agrária). Além de muitas informações sobre os guerrilheiros, em outubro de 1973 o exército possuía mapa detalhado da população local e fichas sobre 400 moradores com indicação de seu potencial compromisso ou colaboração com os militantes do PC do B (DMA, p.198).

A terceira e última campanha militar de combate à guerrilha, a Operação Marajoara, começou em 07 de outubro de 1973 e terminou, provavelmente, em 25 de outubro de 1974, com a última morte conhecida. A operação contou com os agentes presentes no local e mais um conjunto de militares (estimados entre 250 e 750) especialmente treinados para combate direto na floresta, além do apoio aeronáutico. Sempre segundo o DMA, a ordem era não fazer prisioneiros. Torturas e métodos truculentos contra a população civil também foram utilizados. O comando foi realizado diretamente pela Presidência da República e o general Médici. De acordo com uma fonte, haveria 56 guerrilheiros, sendo 6 camponeses recrutados pelos militantes na região. Ao final da operação, 47 guerrilheiros estariam desaparecidos. Há indicações e relatos de que os corpos foram identificados, fotografados e digitais extraídas antes de serem enterrados (DMA, p.198/199).

Em 1975, os militares teriam executado uma "Operação Limpeza", a fim de eliminar os vestígios da guerrilha. Há relatos e informações de que corpos foram desenterrados e queimados ou atirados nos rios. As informações da existência de uma operação limpeza são contestadas por familiares, que acreditam na possibilidade de ainda existir corpos a serem encontrados (DMA, p. 199).

A história sobre o que aconteceu no Araguaia ainda está sendo reconstruída. Ao longo dos anos, familiares, membros do governo e pesquisadores colheram muitos relatos e depoimentos de camponeses, militantes e oficiais do exército sobre os acontecimentos. Muitos documentos foram encontrados, mas há indícios de que haveria ainda muitas fontes inéditas provenientes do exército. No Apêndice III, podem ser encontradas referências de obras e alguns documentos importantes sobre a guerrilha (DMA, p.200/201). 
Desse relato, nos interessam algumas proposições. Primeiro, o efetivo militar da guerrilha era pequeno (cerca de 70 militantes) e contava com armamento precário. Segundo, assim como relatado na seção anterior, não apenas a resistência armada sofreu a repressão, mas também colaboradores pacíficos e a população civil. Terceiro, muitos corpos de desaparecidos ainda não foram encontrados. Quarto, ainda faltam informações sobre os eventos e há indícios da existência de documentos arquivados em poder do exército que ajudariam a esclarecer o ocorrido. Um desses documentos é o Projeto Orvil, mencionado pelo DMA (p. 201) e pelo Coronel Ustra (USTRA, p.11/12), que seria a resposta dos militares ao Projeto BNM, terminado em 1987, segundo o coronel, mas nunca publicado.

\section{Seção III.1.C O Processo Político de Anistia}

Esta seção foi escrita principalmente com base no livro Um Acerto de Contas com o Futuro: a anistia e suas consequências : um estudo do caso brasileiro, de Glenda Mezarobba $^{64}$. Esse trabalho baseia-se em pesquisa aprofundada dos fatos, incluindo o levantamento de notícias, a realização de entrevistas e até mesmo o exame do arquivo particular do general Golbery do Couto e Silva. Conta a história do processo político da anistia, estudando o contexto, os processos legislativos de elaboração e a aplicação da Lei de Anistia ( $n^{\circ}$ 6.683/1979), da Lei dos Desaparecidos (lei 9.140/1995) e da Lei do Anistiado Político (Lei 10.559/2002).

Serão feitas referências ainda a notícias de jornais e revistas sobre o assunto. O tema da anistia, mortes, torturas, desaparecidos e da responsabilização pelo que ocorreu no regime militar nunca sumiu da mídia, como se poderá observar no Apêndice III que apresenta uma lista de notícias desde 1979 até 2012.

\footnotetext{
${ }^{64}$ MEZAROBBA, Glenda. Um Acerto de Contas com o Futuro: a anistia e suas consequências: um estudo do caso brasileiro. São Paulo: Associação Editorial Humanitas - FAPESP, 2006
} 
O projeto da Lei de Anistia, elaborado principalmente pelo Ministro da Justiça Petrônio Portella, foi assinado pelo então presidente João Baptista Figueiredo em 27 de junho de 1979 para logo depois ser enviado ao Congresso Nacional. As pressões eram grandes e antigas; haviam começado logo após a tomada do poder pelos militares e sempre fizeram parte do debate político ao longo do regime (MEZAROBBA, p.23/37). O projeto surgia em um momento de distensão e abertura do regime que preparava a devolução do governo aos civis ${ }^{65}$. Em 13 de outubro de 1978, por exemplo, havia sido promulgada a Emenda Constitucional $\mathrm{n}^{\circ} 11$, que em seu Art. $3^{\circ}$ revogava os famigerados Atos Institucionais.

À época da assinatura e discussão do projeto, foram divulgados levantamentos que buscavam mostrar a anistia em números. Não somente dos beneficiados, mas daqueles que seriam excluídos. O governo mantinha a posição de que atos da oposição armada seriam terroristas e violentos, devendo ser considerados "crimes contra a humanidade", e não

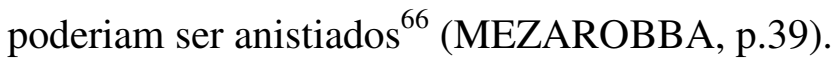

Levantamento mencionado pela revista Veja, edição de 27 de junho de 1979, na reportagem A Anistia de 1979, trouxe os seguintes dados sobre os beneficiados: 166 brasileiros com direitos políticos suspensos, 550 cassados que perderam mandatos eletivos e poderiam voltar a se reeleger, 1261 militares punidos com base em Atos Institucionais, 160 professores que ganhariam o direito de pedir seu cargo de volta, 1729 condenados pela Lei de Segurança Nacional que não se envolveram com a oposição armada. Quanto aos excluídos: 790 condenados pela Lei de Segurança Nacional ${ }^{67}$, sendo 551 condenados por assalto a banco de acordo com o Art. 27 do Decreto-Lei 898/1969 e 239 condenados por atos de terrorismo de acordo com o Art. 28 do mesmo diploma normativo. Dos condenados por assalto a banco 466 eram considerados simples "ladrões" pela Justiça Militar e não

\footnotetext{
${ }^{65}$ Discute-se se a devolução do governo aos civis veio em decorrência de pressões populares e da oposição ao governo, ou se era um objetivo político dos militares, cujo intento seria somente o de ocupar o poder temporariamente para afastar a ameaça comunista, como defende o Coronel Ustra (USTRA, 2012, p.443/444). Para fins deste trabalho, só é importante o contexto de abertura, não sendo relevante a causa política que motivou a abertura.

${ }^{66}$ Conforme noticiado também em VEJA. A Anistia de 1979. Edição 564, 27 de junho de 1979, p. 23. Disponível em http://veja.abril.com.br/acervodigitall. Acesso em 11 de março de 2012.

${ }^{67} \mathrm{Na}$ reportagem fala-se primeiro em 700 condenados, mas depois trata de 551 condenados por assalto a banco e 239 por atos de terrorismo, o que totalizaria 790 .
} 
militavam em organizações da esquerda, portanto, não fariam parte da discussão sobre a anistia. Restariam, portanto, 85 condenados por assalto a banco vinculados à oposição política e excluídos da anistia.

Após o envio do projeto de lei para o Congresso Nacional, foi criada Comissão Mista para sua análise, sendo designado para Relator o deputado Ernani Satyro (Arena/PB) e para presidente o senador Teotônio Vilela (MDB/AL). O relator deveria analisar as propostas de emenda recebidas e elaborar parecer endereçado à Comissão. Esta, tomando por base as informações do parecer, deliberaria sobre eventual proposta consolidada de modificações que julgasse necessárias e, em seguida, enviaria o projeto ao plenário (MEZAROBBA, p.40).

Foram realizadas 305 propostas de emendas, oriundas de 134 parlamentares diferentes, 26 senadores e 108 deputados federais. 49 dos 134 parlamentares pertenciam à Arena. As emendas discutiam inúmeros problemas do projeto: a definição de crimes políticos, a extensão temporal da anistia, a necessidade de requerimento de reintegração no cargo, a ser julgado por comissão, os casos das pessoas punidas por infrações disciplinares e não diretamente com base na Lei de Segurança Nacional nem em Atos Institucionais, dentre outros (MEZAROBBA, p. 42/43).

Merecem destaque duas críticas, ambas relacionadas ao $\S 2^{\circ}$ do Art. $1^{\circ}$ do projeto. A primeira, destacada por Teotônio Vilela, atacava o fato de o projeto, por uma falha de redação, deixar de fora da anistia os condenados por alguns crimes (violentos ou de terrorismo), mas conceder anistia aos participantes não condenados (por exemplo, foragidos). Criava-se assim, segundo o senador, uma situação absolutamente injusta, em que duas pessoas que tivessem participado da mesma ação seriam julgadas de maneiras diferentes (MEZAROBBA, p. 40/41). A discussão sobre a injustiça do projeto também alcançou os meios de comunicação, como mostra, por exemplo, a notícia Limites em Discussão, da Revista Veja de 11 de julho de $1979^{68}$.

68 VEJA. Limites em Discussão. Edição 566, 11 de julho de 1979, p. 25-27. Disponível em http://veja.abril.com.br/acervodigital/. Acesso em 13 de dezembro de 2012. 
A segunda crítica, defendida por Humberto Lucena (MDB/PB), Pacheco Chaves (MDB/SP) e a seção da OAB em São Paulo, tratava da inconsistência de serem excluídos da anistia crimes da esquerda armada, mas não serem excluídos os crimes de tortura e homicídio dos agentes do Estado. Para esses críticos, ou os agentes do Estado que cometeram atrocidades também eram excluídos do grupo de beneficiados ou então a anistia deveria ser concedida a todos, sem restrições (MEZAROBBA, p.44).

Ao concluir o seu parecer, Ernani Satyro rejeitou a maioria absoluta das propostas de emenda, ignorando algumas críticas ao projeto e reafirmando a posição do governo de que a anistia seria restrita e a oposição armada não seria beneficiada. Na ocasião, Satyro citou inclusive pesquisa realizada pelo Instituto Gallup a pedido da revista Veja, que mostrava que $62 \%$ dos brasileiros pretendia que a anistia fosse concedida com restrições, excluindo-se os casos de violência e corrupção. Ainda segundo a pesquisa, apenas $18 \%$ entendiam que a anistia deveria ser concedida sem restrições, sendo que $8 \%$ defendiam que ela não deveria ser concedida, e $12 \%$ não tinham opinião a respeito ${ }^{69}$. Não obstante as rejeições, Satyro apresentou projeto substitutivo em virtude de outras alterações de redação e adição de artigos. O parecer e o projeto foram aprovados pela Comissão (MEZAROBBA, p.45/47).

Em 21 e 22 de agosto de 1979, foram realizadas as sessões plenárias para julgamento do projeto de lei da Anistia, em um cenário tenso, conturbado e com manifestações do público no Congresso e em várias regiões do país. Novas tentativas de emendas da oposição foram rejeitadas, e o projeto substitutivo proposto pela Comissão foi aprovado em plenário, sempre por vantagens apertadas. Terminada a votação o projeto foi devolvido ao presidente Figueiredo para sanção (MEZAROBBA, p.48/50).

Em 28 de agosto de 1979, foi sancionado o projeto, com veto parcial à expressão "e outros diplomas legais" que constava do final do caput do Art. $1^{\circ}$. A Lei de Anistia recebeu o no 6.683/1979 e foi publicada no Diário Oficial da União no mesmo dia. Em referência

\footnotetext{
${ }^{69}$ Essas porcentagens foram obtidas a partir do universo de $65 \%$ dos entrevistados que declarou ter interesse ou informações sobre a questão da anistia. Foram ouvidas 3012 pessoas em 282 cidades do país, incluindo entrevistados de todos os níveis sócio-econômicos, idades e estados. Maiores detalhes sobre a pesquisa podem ser consultados na íntegra da reportagem. VEJA. Anistia? Só restrita... Edição 554, 18 de abril de 1979, p. 20-23. Disponível em http://veja.abril.com.br/acervodigital/. Acesso em 13 de dezembro de 2012.
} 
ao lema "anistia ampla, geral e irrestrita", defendida por alguns grupos, a Veja de 29 de agosto de 1979, na reportagem A Página Virada, disse sobre a anistia aprovada ${ }^{70}$ :

"Como o governo sempre quis, ela não será ampla, pois não beneficia terroristas presos, nem geral, porque distingue entre os crimes perdoados, nem irrestrita, porque não devolve aos punidos os cargos e patentes perdidos." (p. 20)

A redação final do Artigo $1^{\circ}$, caput, $\S \S 1^{\circ}$ e $2^{\circ}$, da Lei da Anistia ficou assim:

Art. $1^{o}$ É concedida anistia a todos quantos, no período compreendido entre 02 de setembro de 1961 e 15 de agosto de 1979, cometeram crimes políticos ou conexo com estes, crimes eleitorais, aos que tiveram seus direitos políticos suspensos e aos servidores da Administração Direta e Indireta, de fundações vinculadas ao poder público, aos Servidores dos Poderes Legislativo e Judiciário, aos Militares e aos dirigentes e representantes sindicais, punidos com fundamento em Atos Institucionais $e$ Complementares (vetado).

$\S 1^{o}$ - Consideram-se conexos, para efeito deste artigo, os crimes de qualquer natureza relacionados com crimes políticos ou praticados por motivação política.

$\S \mathbf{2}^{\boldsymbol{o}}$ - Excetuam-se dos benefícios da anistia os que foram condenados pela prática de crimes de terrorismo, assalto, seqüestro e atentado pessoal."

Alguns criminosos condenados por crimes contra a segurança nacional, aos quais não se aplicou a Lei de Anistia, foram beneficiados por um indulto concedido mais tarde (MEZAROBBA, p.52), por meio do Decreto 84.223 de 20 de novembro de 1979. Com esse indulto, eles obtiveram a diminuição de suas penas, o que resultou na sua liberação imediata. Não houve discriminação entre criminosos políticos e criminosos comuns, sendo

70 VEJA. A página virada. Edição 573, 28 de agosto de 1979. Disponível em http://veja.abril.com.br/acervodigital/. Acesso em 01 de fevereiro de 2012. 
excluídos do indulto apenas os crimes de tráfico de entorpecentes (Art. $6^{\circ}$ ). Destaque-se que o indulto reduziu as penas, mas os criminosos não deixaram de pagar (ainda que menos) pelos crimes que haviam cometido.

Vale mencionar ainda que antes mesmo da anistia alguns condenados já haviam se beneficiado da edição da Lei 6.620 de 17 de dezembro de 1978, que dispunha sobre os crimes de Segurança Nacional. Essa lei substituiu os diplomas legislativos anteriores, aprovados entre 1969 e 1972, no ápice da repressão. A Lei 6.620/1978 reduziu as penas de diversos crimes, o que permitiu que alguns condenados fossem soltos por beneficiarem-se da retroação benéfica da lei penal ${ }^{71}$.

Alguns anos depois, a Emenda Constitucional n ${ }^{\circ}$ 26, de 27 de novembro de 1985, que convocou a Assembleia Nacional Constituinte, voltou a tratar do tema da anistia. No geral, repetiu os termos da Lei de Anistia, com pequenas alterações no cálculo de aposentadoria para quem houvesse perdido o posto de trabalho (conforme detalhado adiante, ao tratar da Lei do Anistiado Político). Em relação à parte criminal, limitou-se a dizer, no $\S 1^{\circ}$ de seu Artigo $4^{\circ}$ :

“Art. $4^{o}$ É concedida anistia a todos os servidores públicos civis da Administração direta e indireta e militares, punidos por atos de exceção, institucionais ou complementares.

$\$ 1^{\circ} \underline{\text { É concedida, igualmente, anistia aos autores de crimes políticos }}$ ou conexos, e aos dirigentes e representantes de organizações sindicais e estudantis, bem como aos servidores civis ou empregados que hajam sido demitidos ou dispensados por motivação exclusivamente política, com base em outros diplomas legais."

Vale destacar que a EC n ${ }^{\circ} 26 / 1985$ não incorporava a redação do Art. $1^{\circ}, \S \S 1^{\circ}$ e $2^{\circ}$ da Lei de Anistia, que tratava da conexão por motivação política e da exclusão dos crimes violentos. Conforme o relato de Glenda Mezarobba (MEZAROBBA, p.55/57) e as notícias

\footnotetext{
${ }^{71}$ Nesse sentido o depoimento de Belisário dos Santos Júnior, em Secretaria Especial de Direitos Humanos, 2007 - (DMA), p. 31
} 
de época $^{72}$, a ideia de tratar de anistia na EC no 26/1985 surgiu para debater uma extensão da anistia para militares cassados em virtude de atos administrativos. O texto da Emenda nesse ponto foi inclusive votado em separado.

Em 1988, por ocasião da promulgação da Constituição Federal de 1988, o tema da anistia foi referido no Artigo $8^{\circ}$ do Ato das Disposições Constitucionais Transitórias, que deixou de fazer qualquer menção a crimes políticos ou conexos.

Algumas proposições ficam claras a partir desse relato sobre a Lei de Anistia e merecem ser destacadas. Em primeiro lugar, o objetivo da Lei 6.683/1979 era não anistiar a oposição armada. Segundo as razões oferecidas pelo próprio governo, os atos violentos deveriam ser considerados "crimes contra a humanidade" e não poderiam ser anistiados. Isso era de conhecimento geral e foi divulgado até mesmo pelos meios de comunicação à época. A exclusão constou expressamente do Art. $1^{\circ}, \S 2^{\circ}$ da Lei de Anistia.

Na prática, uma parte da oposição armada acabou sendo beneficiada pela interpretação que se deu ao Art. $1^{\circ}, \S 2^{\circ}$ da Lei, que distinguia entre condenados e não condenados. Assim, apenas aqueles que haviam sido condenados por sentença transitada em julgado foram excluídos. Outros se beneficiaram do indulto posterior à anistia. Quanto a estes últimos, o que fizeram não deixou de ser considerado crime, tendo eles pagado parte significativa das penas a que foram originalmente condenados.

Em segundo lugar, não se encontram indícios de qualquer "acordo político" entre o governo e a oposição armada. A descrição do processo legislativo mostra que o governo aprovou a anistia que quis, rejeitando ou ignorando as propostas de modificação, inclusive aquelas que tratavam da exclusão de violações cometidas por agentes do Estado ou de uma anistia sem restrições. Não há registros de qualquer negociação, e não há notícias da época que tratem disso, apenas de críticas à vagueza do texto da lei, que permitiria uma interpretação em favor dos agentes da repressão.

72 VEJA. A Constelação da Crise. Edição 895, 30 de outubro de 1985, p. 36-40. Disponível em http://veja.abril.com.br/acervodigital/. Acesso em 13 de dezembro de 2012; FOLHA DE SÃO PAULO. Congresso promulga emenda que convoca constituinte. Edição de 28 de novembro de 1985. (Primeiro Caderno, p.9) Disponível em http://acervo.folha.com.br. Acesso em 13 de dezembro de 2012. 
Por fim, destaca-se que a Lei de Anistia foi elaborada em um contexto de abertura lenta e gradual do regime militar, de preparação para devolução do governo aos civis.

\section{$\underline{\text { Lei dos Desaparecidos (Lei }{ }^{\circ} \text { 9.140/1995) }}$}

Para esta seção são especialmente importantes dois livros: Dos filhos deste solo, de Nilmário Miranda e Carlos Tibúrcio, e o referido Direito à Memória e à Verdade, editado pela Secretaria de Direitos Humanos da Presidência da República. Nilmário Miranda foi peça importante na história da criação da Lei dos Desaparecidos e atuou na Comissão criada por ela. Quanto ao segundo livro, é o relato oficial publicado a partir do resultado dos trabalhos da mesma Comissão.

Um dos problemas que a Lei de Anistia não resolveu foi o dos desaparecidos políticos, aqueles que sofreram o chamado desaparecimento forçado. Esta prática consistiu na privação de liberdade de um indivíduo, geralmente seguida da sua execução e ocultação dos seus restos mortais. Foi um método bastante utilizado pelos regimes militares latinoamericanos para eliminar seus opositores.

O nome "desaparecimento forçado" vem do fato de que o aparato militar negava qualquer informação sobre o indivíduo, inclusive sobre a sua captura, tratando-o não como um prisioneiro, mas como um desaparecido. No cárcere, desaparecidos não tinham quaisquer direitos, pois oficialmente não estavam lá. Além disso, desaparecidos não entravam nas estatísticas de mortos e não era necessário inventar versões oficiais (que corriam o risco de ser derrubadas) para esconder assassinatos. De acordo com o BNM, trata-se do estágio máximo da repressão política em um regime (BNM, p. 258).

Apesar de o problema ser de conhecimento geral, mesmo após a Lei de Anistia o governo evitava tocar no assunto e, quando pressionado, negava sistematicamente a prática do desaparecimento forçado. Não reconhecia sequer a prisão dos desaparecidos políticos, muito menos a sua morte (MEZAROBBA, p.71/72). Apesar da postura do governo, os familiares das vítimas e outros militantes da causa insistiam em exercitar a memória e manter o assunto na agenda política, pressionando para que o tema recebesse tratamento oficial adequado (MEZAROBBA, p.75). 
O assunto ganhou espaço na agenda política do Congresso Nacional em 29 de agosto de 1991. Por ocasião da homenagem ao $12^{\circ}$ Aniversário da Lei da Anistia, o deputado Nilmário Miranda (PT/MG), ex-militante do Polop e ex-preso político, apresentou requerimento propondo a criação de uma Comissão de Representação Externa de Busca dos Desaparecidos Políticos. O trabalho da Comissão, que durou até 1994, consistiu em ajudar os familiares na sua busca pelos corpos e por novas informações sobre os desaparecidos junto a testemunhas e diversos órgãos do governo (MEZAROBBA, p.80/83; MIRANDA, TIBÚRCIO, p.19/20).

Em 1995, o tema voltou à pauta política. Em março daquele ano, em virtude de projeto do deputado Nilmário Miranda, foi instalada na Câmara dos Deputados comissão com o objetivo de tratar exclusivamente de direitos humanos. Logo após sua instalação, foi marcada audiência pública com o então Ministro da Justiça, Nelson Jobim, para que se discutisse a agenda dos trabalhos da nova comissão. Com destaque estava o tema dos desaparecidos políticos. A pressão agora contava com o apoio de entidades nacionais, como a $\mathrm{OAB}$ e a Igreja Católica, e de entidades internacionais, como a Anistia Internacional e a Human Rights Watch / Américas (MEZAROBBA, p.84).

Os familiares pretendiam que a discussão também revisse a Lei de Anistia para que fosse permitida a punição dos culpados pelos desaparecimentos forçados. No entanto, o deputado Nilmário Miranda entendia que isso não era cabível e demandava do governo o envio de um projeto de reparação às famílias das vítimas, em virtude de responsabilidade objetiva do Estado. A demanda foi encaminhada pelo Ministro Nelson Jobim ao seu chefe de gabinete José Gregori (MEZAROBBA, p. 84).

A pressão internacional viria a ganhar a mídia em abril daquele ano por meio das críticas de Pierre Sané, secretário-geral da Anistia Internacional, ao Presidente Fernando Henrique Cardoso. Segundo Sané, o presidente não demonstrara "entusiasmo" em discutir o assunto por considerá-lo "complicado demais", dentre outros ataques. Em nota oficial, o 
Palácio do Planalto respondeu que na verdade Sané havia interpretado mal o que o presidente dissera $^{73}$ (MEZAROBBA, p. 85).

Em maio, dois novos acontecimentos ocuparam as páginas dos jornais e revistas. Marcelo Rubens Paiva, filho do ex-deputado Rubens Paiva, desaparecido em janeiro de 1971 e amigo de Fernando Henrique Cardoso, partindo das declarações de Sané, escreveu um artigo de duas páginas na revista Veja, intitulado "Nós não esquecemos", realizando apelo pessoal ao presidente para que enfrentasse a questão. De outro lado, o jornal inglês The Guardian denunciou que um suposto ex-torturador, o coronel Armando Avólio Filho, ocupava cargo de destaque na embaixada brasileira em Londres. A Anistia Internacional pediu seu imediato afastamento do cargo (MEZAROBBA, p.86).

Finalmente, em 23 de maio de 1995, o Ministério da Justiça anunciou a intenção do Estado de reconhecer a morte dos desaparecidos e pagar indenização a seus familiares. $\mathrm{O}$ chefe de gabinete José Gregori foi o responsável pela elaboração do Projeto de Lei 869/95, apresentado à Câmara dos Deputados no final de agosto do mesmo ano. Apesar do avanço, o projeto foi recebido com críticas pelos familiares, focadas principalmente: na falta de critérios objetivos para distinguir mortos e desaparecidos; no ônus da prova do desaparecimento ter sido deixado aos familiares; e na impossibilidade de se apurar as circunstâncias e histórias que envolviam as mortes, com a identificação dos crimes e dos responsáveis. Os familiares tinham a esperança de alterar o projeto por meio de emendas (MEZAROBBA, p.87/90).

O projeto tramitou em regime de urgência, e a orientação governamental era para que não houvesse emendas. Apesar de várias terem sido apresentadas, nenhuma foi aprovada. Em entrevista concedida a Glenda Mezarobba, Gregori declarou que não recebera nenhuma sugestão nem imposição de restrição dos militares e que o texto fora resultado de uma reflexão prudente e cautelosa. Paralelamente, a posição do exército, divulgada em nota oficial, era de que não tinha restrições ao pagamento de indenizações, mas era contrário à "apuração de responsabilidades" sobre as mortes (MEZAROBBA, p. 91).

${ }^{73}$ SOUZA, Carlos Alberto de. Dirigente mundial da Anistia critica FHC. Folha de São Paulo. 12 de abril de 1995. Primeiro Caderno, p. 11. Disponível em http://acervo.folha.com.br. Acesso em 13 de dezembro de 2012. 
A lei foi sancionada e promulgada em 04 de dezembro de 1995, recebendo o $\mathrm{n}^{\circ}$ 9.140. Ficou conhecida como a Lei dos Desaparecidos. As críticas dos familiares permaneceram. Além das mencionadas, destaca-se a falta de um esquema amplo de divulgação da entrada em vigor da lei, que dava prazo de apenas 120 (cento e vinte) dias para a apresentação de requerimentos de indenização (Art. $7^{\circ}$ ). Isso impediu que algumas famílias de vítimas soubessem da lei e exercessem seus direitos. O período de abrangência da lei, segundo os familiares, não deveria se encerrar em 1979, mas em 1985, ao final do regime militar. Por fim, atacou-se a exclusão das mortes em manifestações públicas, das mortes de opositores do regime que ocorreram no exterior (por exemplo, Argentina e Chile que também possuíam governos militares), ou daqueles que cometeram suicídio relacionado à tortura ou à sua ameaça (MEZAROBBA, p.94/95; MIRANDA, TIBÚRCIO, p.20/21).

A Lei 9.140/95, em seu Artigo $1^{\circ}$, reconhecia como:

“mortas, para todos os efeitos legais, as pessoas relacionadas no Anexo I desta lei, por terem participado, ou terem sido acusadas de participação, em atividades políticas, no período de 2 de setembro de 1961 a 15 de agosto de 1979, e que, por este motivo, tenham sido detidas por agentes públicos, achando-se, deste então, desaparecidas, sem que delas haja notícias"

O Anexo I contava com o nome de 136 desaparecidos. A lista baseou-se parcialmente em informações obtidas no Dossiê dos Mortos e Desaparecidos Políticos no Brasil 1964-1985, fruto do trabalho conjunto da Comissão de Familiares de Mortos e Desaparecidos Políticos, Instituto de Estudo da Violência do Estado (IEVE) e Grupo Tortura Nunca Mais, publicado com apoio do governo do Estado de Pernambuco. Serviram de fonte ainda o reverendo Jaime Wright e Dom Paulo Evaristo Arns, vinculados ao Projeto Brasil Nunca Mais e anotações pessoais de José Gregori, realizadas na época em que integrou a Comissão de Justiça e Paz da Arquidiocese de São Paulo (DMA, p. 34). 
Além disso, o Artigo $4^{\circ}$ da lei criou Comissão Especial de Mortos e Desaparecidos Políticos (CEMDP) com as atribuições de:

"I - proceder ao reconhecimento de pessoas:

a) desaparecidas, não relacionadas no Anexo I desta Lei;

b) que, por terem participado, ou por terem sido acusadas de participação, em atividades políticas, no período de 2 de setembro de 1961 a 15 de agosto de 1979, tenham falecido, por causas não naturais, em dependências policiais ou assemelhadas;

II - envidar esforços para a localização dos corpos de pessoas desaparecidas no caso de existência de indícios quanto ao local em que possam estar depositados;

III - emitir parecer sobre os requerimentos relativos a indenização que venham a ser formulados pelas pessoas mencionadas no art. 10 desta Lei."

Ou seja, dentre outras funções, a CEMDP resolveria os casos de mortos e desaparecidos não relacionados no Anexo I. Até o prazo final, foram protocolados requerimentos referentes a 366 pessoas, 230 a mais do que o previsto no Anexo I. Destas 366, 132 eram desaparecidos mencionados no Anexo I. Das 234 restantes, 166 tiveram suas histórias relatadas no Dossiê dos Mortos e Desaparecidos Políticos a partir de 1964, e 68 eram casos novos. Até a última reunião sobre processos, em maio de 1998, a CEMDP reconheceu a responsabilidade do Estado pela morte ou desaparecimento de 280 pessoas, sendo que 148 não constavam do Anexo I. Deste grupo de 148, 130 nomes estavam contidos no Dossiê, e 18 eram casos novos. Houve 86 indeferimentos, sendo 36 deles casos relatados no Dossiê (DMA, p.40) 
O trabalho da CEMDP tentou resolver ou diminuir alguns dos problemas da Lei dos Desaparecidos criticados pelos familiares. A CEMDP criou uma distinção precisa entre "mortos" e "desaparecidos", considerando mortos aqueles cujo falecimento fora reconhecido publicamente pelos órgãos do Estado (DMA, p.49). Quanto ao ônus da prova, segundo Belisário dos Santos Junior, membro da Comissão a partir de 2001, a CEMDP:

"desde o início, trabalhou com o entendimento de ser seu dever a descoberta da verdade real. A verdade formal, aquela que resulta da prova dos autos era apenas o início das buscas, em muitos casos. Não obstante a escassa prova ou a falta de prova do requerimento inicial, a Comissão sempre diligenciou, até os limites de suas possibilidades, para obtenção de provas que autorizassem o reconhecimento da morte ou desaparecimento. Houve vários casos em que o resultado final deveu-se mais ao esforço, às pesquisas, às diligências empreendidas pela Comissão que ao material a ela apresentado pela família requerente." (DMA, p.35)

Durante os trabalhos, a CEMDP também viveu momentos de tensão política com o exército. Houve grandes discussões sobre o significado de "dependências policiais ou assemelhadas" previsto no Art. $4^{\circ}$, I, (b). As discussões aumentaram de tom no momento de julgar os casos de Carlos Lamarca e Carlos Marighella, ex-líderes da oposição armada. Ao final, foi reconhecida a responsabilidade do Estado por maioria nos dois casos, contra os votos do general Oswaldo Gomes (representante do exército) e de Gonet Branco (representante do Ministério Público). O julgamento provocou reações do exército dentro e fora da CEMDP. De modo semelhante, o caso de Zuzu Angel também causou estardalhaço na mídia e, ao final, julgou-se pela responsabilidade do Estado por 4 a 3, com voto de minerva do presidente da CEMDP, Miguel Reale Júnior. Em todos os casos venceu a tese de que o conceito de dependência assemelhada não seria físico, mas jurídico-político, relacionando-se ao domínio da situação pelos agentes do Estado (MEZAROBBA, P.96/100) (MIRANDA, TIBÚRCIO, p.22/23). 
É importante destacar que o trabalho da CEMDP em relação à apuração das circunstâncias dos casos se limitava a verificar as provas de desaparecimento ou o momento da morte, por causas não naturais, em situações de domínio de agentes do Estado. Estes eram os requisitos para o reconhecimento da morte nos termos da lei e para a concessão de indenização. Esses limites distinguem os trabalhos desta Comissão da recémcriada Comissão da Verdade, que será tratada mais adiante.

O resultado dos trabalhos da CEMDP com os processos deu origem ao mencionado livro Dos Filhos deste Solo, escrito por Nilmário Miranda e Carlos Tibúrcio, que teve sua $1^{a}$ edição publicada em agosto de 1999. O livro relata os casos de mortos e desaparecidos analisados pela CEMDP, separados de acordo com as organizações políticas a que pertenciam. Tornou-se obra de referência sobre a repressão no regime militar e os trabalhos da CEMDP.

Os trabalhos da CEMDP não terminaram em 1998. A tarefa de envidar esforços para localizar os corpos dos desaparecidos (atribuição prevista no Art. $4^{\circ}$, II da lei) permaneceu. Em 2002, a pedido da própria Comissão, foi editada a Lei 10.536, que ampliou o período de abrangência de 1961-1979 para 1961-1988 (Art. $1^{\text {o }}$ ), e reabriu os prazos para requerimentos de indenização (Art. $2^{\circ}$ ) (MIRANDA, TIBÚRCIO, p.15).

Em 2004, sobreveio nova alteração da Lei dos Desaparecidos por meio da Lei 10.875, que ampliou os casos que poderiam ser analisados pela CEMDP, incluindo pessoas: "que tenham falecido em virtude de repressão policial sofrida em manifestações públicas ou em conflitos armados com agentes do poder público" ou "que tenham falecido em decorrência de suicídio praticado na iminência de serem presas ou em decorrência de seqüelas psicológicas resultantes de atos de tortura praticados por agentes do poder público". A Lei ainda mudou a composição da comissão retirando integrantes das Forças Armadas para substituí-los por membros do Ministério da Defesa e especificou que ela passaria a funcionar junto à então Secretaria Especial dos Direitos Humanos, órgão da Presidência da República, atualmente denominada Secretaria de Direitos Humanos da Presidência da República (conforme Lei 10.683/2003, alterada pela Lei 12.462/2011). 
As modificações da Lei dos Desaparecidos e reaberturas de prazo atenderam ainda às críticas dos familiares quanto à divulgação, prazo e restrições de casos de morte. Após os dois novos prazos, foram apresentados mais 105 requerimentos. Os trabalhos de julgamento de processos se encerraram em 2006, com um saldo de 471 casos de morte ou desaparecimento apresentados, sendo 132 previstos na lista do Anexo I da Lei e 339 não previstos. Dos 339, 221 foram deferidos e 118 indeferidos. Ao final, a CEMDP reconheceu a responsabilidade do Estado e pagou indenização em 353 casos. Do Anexo I original foi excluído o caso de uma pessoa que se descobriu ter morrido de causas naturais, remanescendo 3 casos em que, apesar do reconhecimento da responsabilidade do Estado, não houve pagamento de indenização (DMA, p.17 / p.40/41).

Os dados gerais sobre a CEMDP podem ser comparados com os dados obtidos especificamente sobre a Guerrilha do Araguaia (obtidos em DMA, p. 49 e 203/271). A Guerrilha do Araguaia deu origem a 78 processos na CEMDP (cerca de 16,5\% do total), sendo que 62 casos foram deferidos e 16 indeferidos. A porcentagem de casos deferidos relacionados com a Guerrilha sobre o total de casos deferidos (353) é de aproximadamente 17,5\%. Dos 136 casos previstos no Anexo I, 61 casos (quase 45\%) são relacionados ao Araguaia. Apenas um desses casos não chegou a gerar processo nem pagamento de indenização, pois não foi possível encontrar a família do guerrilheiro. Portanto, 60 dos 62 casos deferidos foram com base no Anexo I, e 2 pedidos foram deferidos após análise da $\mathrm{CEMDP}^{74}$. Os dados mostram a expressividade do caso Araguaia.

Após a conclusão dos trabalhos, a CEMDP publicou, em 2007, o referido livro Direito à Memória e à Verdade, que se transformou no relato oficial dos casos da Comissão. O livro conta ainda com histórico do regime militar, da criação da Lei dos Desaparecidos e suas alterações e da própria Comissão. Foi o primeiro de uma série homônima, toda disponível no site da Secretaria de Direitos Humanos ${ }^{75}$. Em 2008,

\footnotetext{
${ }^{74}$ No livro Direito à Memória e à Verdade há o relato de 64 casos, além de breves comentários sobre os 16 casos indeferidos. Dos 64 casos, 61 são referentes aos nomes constantes do Anexo I, incluindo o de Francisco Manoel Chaves, cuja família não foi encontrada (DMA, p.203). Os 3 casos restantes são de Antonio Ferreira Pinto (p.251), Antonio Araújo Veloso (p.264/265) e Pedro Carretel. Quanto aos dois primeiros houve processo e deferimento do pedido de indenização. Quanto a Pedro Carretel (p.258/259), cujo verdadeiro nome provavelmente seria Pedro Matias de Oliveira, sequer houve processo.

${ }^{75}$ Disponível no endereço http://www.sedh.gov.br/clientes/sedh/sedh/biblioteca/serie-direito-a-memoria-e-averdade
} 
Nilmário Mirando e Carlos Tibúrcio lançaram uma $2^{\mathrm{a}}$ edição do livro Dos filhos deste solo, revista e atualizada a partir das mudanças da Lei dos Desaparecidos e dos novos trabalhos da CEMDP. Em 2009, foi lançada a $2^{\mathrm{a}}$ edição revista e atualizada do Dossiê dos Mortos e Desaparecidos Políticos 1964-1985.

Além da publicação da série, os trabalhos da CEMDP continuaram em duas frentes. Em setembro de 2006 foi iniciada a coleta de amostras de sangue de parentes dos desaparecidos para constituir um Banco de DNA, que possibilite a identificação dos restos mortais encontrados nas investigações. A outra frente de trabalho iniciou a sistematização de informações sobre a localização de covas e valas comuns nas grandes cidades e em áreas de provável sepultamento no meio rural (DMA, p.17).

Quanto às covas com as ossadas de guerrilheiros devem ser feitas algumas considerações. Costuma-se falar, assim como o DMA o fez, em "covas clandestinas". Optamos por dizer apenas "covas", pois há controvérsia se seriam clandestinas ou não. O Coronel Ustra, por exemplo, defende que havia dificuldades de identificação dos guerrilheiros que usavam nomes falsos e que as ossadas teriam sido transferidas para valas comuns após o prazo de cinco anos, já que ninguém teria aparecido para reclamar os corpos. Atente-se que, independentemente dos problemas relacionados à identificação, vala comum não é o mesmo que cova clandestina (USTRA, p.471/478).

Paralelamente aos trabalhos da CEMDP, existiu, de 2003 a 2007, Comissão Interministerial para buscar os restos mortais da Guerrilha do Araguaia, criada pelo Decreto $n^{\circ} 4.850$ de 02 de outubro de 2003. A Comissão Interministerial foi criada pelo governo após sentença dada pela juíza Solange Salgado, da $1^{\text {a }}$ Vara Federal da Justiça Federal do Distrito Federal, no processo no 0000475-06.1982.4.01.3400. Na sentença, determinou-se que a União procedesse à investigação e busca dos corpos dos guerrilheiros do Araguaia. A União Federal recorreu de parte da sentença, mas reconheceu os direitos dos familiares aos restos mortais de seus parentes e o seu dever de envidar esforços para ajudá-los a localizar os corpos (DMA, p. 202). Assim, apesar do recurso, a União criou a Comissão Interministerial. Por algum tempo, houve tensão entre a CEMDP e a Comissão Interministerial, já que parte das suas atribuições era idêntica. Em março de 2007, sem resultados conclusivos, a Comissão Interministerial apresentou relatório final com 
recomendações para o governo, dentre elas que a continuidade dos trabalhos fosse conduzida pela $\mathrm{CEMDP}^{76}$ (DMA, p.43).

Até 2007, quando da edição do livro Direito à Memória e à Verdade, apenas três corpos haviam sido encontrados e sepultados pelos familiares: Maria Lúcia Petit, Luiz Eurico Tejera Lisbôa e Denis Casemiro (DMA, p.49).

Por fim, cabe mencionar que a CEMDP inspirou Comissões Especiais de âmbito estadual, que tinham como objetivo indenizar pessoas detidas sob a acusação de participação em atividades políticas, durante o regime militar, que sofreram danos físicos e psicológicos decorrentes de torturas. Vale destacar que o objeto dessas Comissões não se confunde com o das atividades da CEMDP, pois aquelas não indenizam familiares de mortos e desaparecidos. Como exemplo, no Apêndice III podem ser encontradas referências aos diplomas normativos que criaram Comissões nos Estados do Paraná (1995), Rio Grande do Sul (1997), Minas Gerais (1999) e São Paulo (2001).

Para os debates sobre responsabilização é relevante extrair desse relato duas proposições. Primeiro, que apesar das famílias desejarem que a Lei de Anistia fosse revista para se possibilitar a punição de agentes do Estado, não fez parte do debate legislativo da Lei 9.140/1995 qualquer discussão relativa a crime, pena ou punição. Segundo, que discussões penais eram consideradas fora de questão pelo governo, assumindo-se que qualquer punição de agentes do Estado seria impossível em razão da Lei de Anistia.

\section{Lei do Anistiado Político (Lei 10.559/2002)}

Outro problema que não foi adequadamente resolvido pela Lei de Anistia diz respeito às pessoas que perderam seus postos de trabalho em razão da legislação excepcional e de perseguições políticas do regime militar. Estão incluídos no rol de afetados, servidores públicos, trabalhadores da área privada, militares, professores e até mesmo estudantes.

\footnotetext{
${ }^{76}$ As recomendações do relatório podem ser encontradas em notícia divulgada no site da Secretaria de Direitos Humanos. SECRETARIA DE DIREITOS HUMANOS. Governo divulga relatório final sobre localização de desaparecidos na Guerrilha do Araguaia. 28 de março de 2007. Disponível em http://portal.sdh.gov.br/clientes/sedh/sedh/noticias/ultimas_noticias/2007/03/MySQLNoticia.2007-0328.0542/?searchterm=relat\%C3\%B3rio\%20araguaia. Acesso em 13 de dezembro de 2012.
} 
$\mathrm{O}$ artigo $3^{\circ}$ da Lei de Anistia previa a possibilidade de retorno ao cargo ou posto condicionado necessariamente à existência de vaga e ao interesse da administração. Os pedidos de reintegração seriam analisados por comissões especiais dos órgãos ou instituições em que o indivíduo trabalhava. Tal pedido deveria ser realizado no prazo de 120 dias contados da publicação da lei (Art. $2^{\circ}$ ). Por sua vez, o Art. $4^{\circ}$ determinava que aqueles que não realizassem o pedido no prazo, ou tivessem o pedido indeferido, seriam aposentados, contando-se o tempo de afastamento para fins de cálculo dos proventos da inatividade ou pensão.

Apesar das críticas e pressões que ocorreram durante o processo legislativo da Lei de Anistia, o projeto foi aprovado do modo que o governo queria. Ficaram de fora dos beneficiados os estudantes, sindicalistas e trabalhadores privados. Na prática, a obtenção do benefício de reintegração se tornou extremamente difícil. Não foram raros os casos em que se deixou de requerer a reintegração por temor de represálias, visto que o regime militar perduraria até 1985. A simples contagem do tempo afastado como serviço ativo também não era considerada suficiente, pois os afastados foram impedidos de receber promoção, o que impactava negativamente o benefício final (MEZAROBBA, p.119/120). Além disso, os proventos da aposentadoria tendem a ser inferiores ao salário efetivo, e não haveria reparação pelo que as pessoas haviam deixado de ganhar no período em que estiveram afastadas.

A Emenda Constitucional $\mathrm{n}^{\circ}$ 26, de 27 de novembro de 1985, que convocou a Assembleia Nacional Constituinte, representou o primeiro avanço na questão, ao declarar no $\S 3^{\circ}$ do Artigo $4^{\circ}$ que: "Aos servidores civis e militares serão concedidas as promoções, na aposentadoria ou na reserva, ao cargo, posto ou graduação a que teriam direito se estivessem em serviço ativo, obedecidos os prazos de permanência em atividade, previstos nas leis e regulamentos vigentes."

Posteriormente, o Artigo $8^{\circ}$ do Ato das Disposições Constitucionais Transitórias, promulgado juntamente com a Constituição Federal, viria a confirmar a modificação da EC $\mathrm{n}^{\circ}$ 26/85, ampliar o prazo de 1961 a 1979, para 1946 a 1988, e incluir entre os beneficiados 
trabalhadores do setor privado, dirigentes e representantes sindicais que haviam sido punidos por motivos exclusivamente políticos.

Apesar das mudanças, os avanços ainda eram considerados tímidos. Em entrevista concedida à Glenda Mezarobba, o general Oswaldo Pereira Gomes, assessor especial jurídico e político do Ministro do Exército, participante do lobby das Forças Armadas na Constituinte disse que a orientação era clara: derrubar quaisquer tentativas de alterar a Lei de Anistia. Havia preocupação especial de que não fossem ampliados benefícios aos militares punidos, o que poderia caracterizar uma ameaça aos princípios da hierarquia e da disciplina. O argumento utilizado pelas Forças Armadas era o de que a "anistia possível” já havia sido concedida. Para o General Gomes as alterações aprovadas eram meramente "cosméticas", tendo os resultados sido de acordo com as expectativas das Forças Armadas (MEZAROBBA, p.123/124).

Já na vigência da Constituição Federal de 1988, vários diplomas legislativos seriam utilizados para regular o tema de maneira provisória até que se chegasse à atual Lei do Anistiado Político (Lei 10.559/2002). Em 1991, o Artigo 150 da Lei 8.213/1991 (Lei dos Planos da Previdência Social) viria prever a possibilidade de anistiados obterem aposentadoria em regime excepcional, nos termos de regulamento posterior. Esclarecia-se e facilitava-se assim o cálculo dos vencimentos dos anistiados (MEZAROBBA, p.124/125).

Mas as discussões continuaram, e novas mudanças vieram a ocorrer com a Medida Provisória 2.151/2001 que garantia quatro direitos ao anistiado: (i) declaração da condição de anistiado político; (ii) reparação econômico de caráter indenizatório; (iii) contagem do tempo em que esteve afastado para fins previdenciários; (iv) conclusão de curso interrompido e reconhecimento de diploma obtido no exterior. Em 2002, a regulação foi aprimorada e surgiu a Medida Provisória 65/2002, resultado do esforço conjunto do Ministério da Justiça, Casa Civil e Legislativo, bem como de entidades de anistiados. Essa MP foi submetida ao Congresso Nacional e convertida na Lei 10.559/2002, que seria também conhecida como Lei do Anistiado Político (MEZAROBBA, p.130/136). 
Além de garantir os quatro direitos mencionados, a Lei do Anistiado Político criou a Comissão de Anistia, no âmbito do Ministério da Justiça, para receber os requerimentos de indenização e julgá-los (Art. 12). Em Relatório referente ao ano 2010 (último disponível no site $)^{77}$, a Comissão informa que ao final daquele ano já haviam sido apresentados 68.517 requerimentos (p.15) e apreciados 57.628, com 38.025 deferimentos e 19.603 indeferimentos (p.119).

A Lei do Anistiado Político oferece ao anistiado duas formas de reparação econômica, em prestação única ou em prestação mensal e continuada (Arts. $3^{\circ}$ a $9^{\circ}$ ). Até o final de 2010, haviam sido pagos $\mathrm{R}$ \$ 215.331.511,13 a título de prestação única e $\mathrm{R}$ \$ 36.404.755,92 a título de prestação mensal e continuada (p.120). Ou seja, foram gastos mais de duzentos e cinquenta milhões de reais com reparações econômicas aos anistiados.

Os trabalhos da Comissão de Anistia permanecem e não há prazo limite para apresentação dos requerimentos.

\section{$\underline{\text { Supremo Tribunal Federal e ADPF } 153}$}

Em 21 de outubro de 2008 foi protocolada a Arguição de Descumprimento de Preceito Fundamental no 153 (“ADPF 153”). A ação, interposta pela Ordem dos Advogados do Brasil e assinada pelos advogados Fábio Konder Comparato e Maurício Gentil Monteiro, buscava que fosse dada à Lei no 6.683/1979 (Lei de Anistia) uma:

“interpretação conforme à Constituição, de modo a declarar, à luz dos seus preceitos fundamentais, que a anistia concedida pela citada lei aos crimes políticos ou conexos não se estende aos crimes comuns praticados pelos agentes da repressão contra opositores políticos, durante o regime militar (1964/1985).” (p.29 da Petição Inicial)

\footnotetext{
${ }^{77}$ Para se obter o Relatório deve-se acessar o site do Ministério da Justiça http://portal.mj.gov.br, entrar em "Anistia Política", "Publicações" e selecionar "Relatórios". BRASIL. Ministério da Justiça. Comissão de Anistia. Relatório Anual da Comissão de Anistia 2010. Brasília: Comissão de Anistia, 2010. Acesso em 13 de dezembro de 2012.
} 
Em 29 de abril de 2010, a ADPF 153 foi julgada improcedente em sessão plenária por maioria dos votos. Estavam presentes os ministros Cezar Peluso, Celso de Mello, Marco Aurélio, Ellen Gracie, Gilmar Mendes, Ayres Britto, Ricardo Lewandowski, Carmen Lúcia e Eros Grau (relator). Ficaram vencidos os Ministros Ricardo Lewandowski e Ayres Britto, que davam provimento parcial ao recurso nos termos de seus votos. $\mathrm{O}$ placar foi de 7 x 2 .

Após a publicação do acórdão, em 13 de agosto de 2010 a OAB apresentou recurso de Embargos de Declaração. Até 03 de janeiro de 2013 o recurso continua pendente de julgamento. Ou seja, a questão ainda não foi definitivamente resolvida pelo Supremo Tribunal Federal.

Corte Interamericana de Direitos Humanos e o Caso Gomes Lund e outros v. Brasil ("Guerrilha do Araguaia”)

Em 7 de agosto de 1995 o Centro pela Justiça e pelo Direito Internacional (CEJIL) e a Human Rights Watch / Americas apresentaram petição em nome de pessoas desaparecidas no contexto da Guerrilha do Araguaia à Comissão Interamericana de Direitos Humanos, dando origem ao Caso ${ }^{\circ} 11.552$.

Em 6 de março de 2001, a Comissão expediu o Relatório de Admissibilidade $n^{\circ}$ 33/01, declarando que o caso era admissível em relação à suposta violação dos Artigos 4, 8, 12, 13 e 25, combinados com o Artigo 1.1 da Convenção Americana de Direitos Humanos (também conhecida como Pacto de São José da Costa Rica). Declarou ainda que o caso seria admissível também para análise da suposta violação dos Artigos I, XXV e XXVI da Declaração Americana dos Direitos e Deveres do Homem.

Em 31 de outubro de 2008 a Comissão aprovou o Relatório de Mérito nº 91/08, concluindo pela responsabilidade do Estado por violações dos direitos humanos estabelecidos nos artigos I, XXV e XXVI da Declaração Americana, bem como nos artigos 4, 5 e 7, em conexão com o artigo 1.1 da Convenção Americana, em detrimento das vítimas desaparecidas; nos artigos XVII da Declaração Americana e 3, combinado com o 
artigo 1.1 da Convenção Americana, em detrimento das vítimas desaparecidas; nos artigos I da Declaração Americana e 5, em conexão com o artigo 1.1 da Convenção Americana, em detrimento dos familiares dos desaparecidos; no artigo 13, combinado com o artigo 2 da Convenção Americana, em detrimento dos familiares dos desaparecidos; nos artigos XVIII da Declaração Americana e 8.1 e 25 da Convenção Americana, combinados com os artigos 1.1 e 2 da mesma Convenção, em detrimento das vítimas desaparecidas e de seus familiares, em virtude da aplicação da Lei de Anistia; nos artigos XVIII da Declaração Americana e 8.1 e 25, combinados com o artigo 1.1 da Convenção Americana, em detrimento das vítimas desaparecidas e de seus familiares, em virtude da ineficácia das ações judiciais não penais interpostas em relação ao caso.

A Comissão apresentou ainda várias recomendações ao Estado e concedeu um prazo de dois meses para que o Brasil informasse sobre o seu cumprimento. Após duas prorrogações de prazo, o Brasil não implementou satisfatoriamente as medidas recomendadas. Desse modo, a Comissão resolveu submeter o caso à Corte Interamericana de Direitos Humanos (CIDH).

O caso foi julgado pela CIDH em 24 de novembro de 2010, alguns meses após a decisão do STF na ADPF 153. A CIDH concluiu pela incompatibilidade da interpretação que anistiava os agentes do Estado responsáveis por violações de direitos humanos (tortura, execuções e desaparecimentos forçados) com a Convenção Americana de Direitos Humanos. Determinou, dentre outras medidas reparatórias, que fosse conduzida a investigação penal dos fatos, com aplicação efetiva de sanções que a lei previsse, e que não fosse aplicada qualquer disposição que excluísse a responsabilidade ou a punibilidade dos agentes (doravante, “Caso Gomes Lund").

Até 03 de janeiro de 2013 não foi localizado no site da Corte Interamericana de Direitos Humanos qualquer decisão de Supervisão de Sentença relativa ao caso da Guerrilha do Araguaia. 


\section{Comissão Nacional da Verdade (Lei 12.528/2011)}

Recentemente a Lei 12.528/2011 criou a Comissão Nacional da Verdade (CNV), com o objetivo de esclarecer de maneira aprofundada as graves violações de direitos humanos que ocorreram no país de 1946 até 1988, indicar os responsáveis pela autoria de torturas, mortes, desaparecimentos forçados e ocultação de cadáveres, e fornecer um mapa da estrutura repressiva do Estado (Arts. $1^{\circ}$ e $3^{\circ}$ ). A CNV terá um prazo de dois anos, a partir de sua instalação, para apresentar relatório com suas conclusões e recomendações (Art. 11). O trabalho da $\mathrm{CNV}$ pode ser compreendido como uma extensão e aprofundamento do trabalho promovido pela CEMDP.

Importante apontar que a Lei de Acesso à Informação (Lei $\left.n^{\circ} 12.527\right)$, que trata também do sigilo de documentos no país, foi promulgada no mesmo dia da lei que criou a CNV, 18 de novembro de 2011. A revisão da regulação do sigilo não é casual, e espera-se que a sua alteração possa facilitar o acesso a documentos inéditos e ajudar no desenvolvimento dos trabalhos da Comissão.

A Comissão foi instituída em maio de 2012, tendo como membros Cláudio Fonteles (ex-Procurador Geral da República), Gilson Dipp (vice-presidente do Superior Tribunal de Justiça), José Carlos Dias (advogado, ex-Ministro da Justiça), José Paulo Cavalcanti Filho (advogado e ex-Ministro (interino) da Justiça), Maria Rita Kehl (psicanalista), Paulo Sérgio Pinheiro (cientista político e ex-Secretário de Direitos Humanos) e Rosa Maria Cardoso Cunha (advogada e professora) ${ }^{78}$.

Desde a sua instalação já houve notícias de divergência entre os integrantes da CNV sobre o escopo do trabalho. José Carlos Dias defendia que o trabalho da comissão também envolvesse a apuração dos atos violentos cometidos pela oposição armada, enquanto Rosa Maria Cardoso Cunha sustentava que a CNV apurasse somente os atos

\footnotetext{
${ }^{78}$ Conforme informações obtidas na página oficial (provisória) da CNV: $\underline{\text { http://www.cnv.gov.br/ }}$
} 
cometidos por agentes do Estado ${ }^{79}$. Ao que tudo indica a Comissão decidiu apurar apenas atos praticados por agentes públicos, conforme informações divulgadas em seu site oficial $^{80}$.

Inspirados na CNV, outros entes federativos e instituições implantaram suas próprias comissões da verdade, como, por exemplo, a Câmara Municipal de São Paulo (Resolução 3/2012) $^{81}$, a Assembleia Legislativa do Estado de São Paulo (Resolução 879/2012), a Seção de São Paulo da Ordem dos Advogados do Brasil (Portaria 237/12/PR) ${ }^{82}$ e a própria Faculdade de Direito do Largo de São Francisco da Universidade de São Paulo (FADUSP) ${ }^{83}$. Todas essas instituições estão em pleno funcionamento, colhendo informações para produção de seus relatórios, que devem ficar prontos nos próximos anos.

\section{SECÃO III.2 MAPA ARGUMENTATIVO EM PROTOCOLO DE DISPUTAS}

O Mapa Argumentativo desta seção apresenta os debates sobre a responsabilização do Estado e dos militares pelos assassinatos, torturas e desaparecimentos forçados, nos âmbitos administrativo, penal e civil. Expõe também as discussões sobre a investigação da verdade histórica acerca do ocorrido e a preservação de sua memória.

\footnotetext{
${ }^{79}$ Ver, por exemplo, LUNA, Denise. Alvo de comissão é ditadura e não guerrilha, diz integrante. Folha de São Paulo. 15 de maio de 2012. Primeiro Caderno, p. A4. Disponível em http://acervo.folha.com.br. Acesso em 16 de julho de 2012.

${ }^{80}$ Em notícia de 02 de julho de 2012, consta: "SOBRE A COMISSÃO DA VERDADE - A Comissão Nacional da Verdade foi criada pela Lei 12528/2011 e instituída em maio de 2012. Ela tem por finalidade apurar graves violações de Direitos Humanos, praticadas por agentes públicos, ocorridas entre 18 de setembro de 1946 e 5 de outubro de 1988." COMISSÃO NACIONAL DA VERDADE. Comissão da Verdade define estratégias de funcionamento e estrutura. 2 de julho de 2012. Disponível em http://www.cnv.gov.br/noticias/02-07-2012-comissao-da-verdade-define-estrategias-de-funcionamento-eestrutura/. Acesso em 03 de janeiro de 2013.

81 A página da comissão pode ser encontrada no endereço http://www.camara.sp.gov.br/index.php?option=com_content\&view=article\&id=11510:comissao-daverdade $\&$ Itemid $=300$

82 JORNAL DO ADVOGADO OAB/SP. Instituída a Comissão da Verdade da OAB/SP. Ano XXXVIII, Edição 374, Julho/2012, p.16/17

${ }^{83}$ GENESTRETI, Guilherme. Faculdade de Direito da USP aprova 'Comissão da Verdade' na instituição. Folha de São Paulo. 27 de setembro de 2012. Disponível em http://www1.folha.uol.com.br/saopaulo/1160451-faculdade-de-direito-da-usp-aprova-comissao-da-verdadena-instituicao.shtml. Acesso em 03 de janeiro de 2013.
} 
Por questões de tamanho e de foco, o Mapa que será apresentado possui limitações. Há discussões que serão apenas mencionadas, sem que se entre no debate propriamente dito. Também há debates que serão apresentados com maior nível de detalhe do que outros.

A variação do nível de detalhe possui a vantagem de mostrar a ferramenta da diagramação de argumentos operando em níveis diversos (conforme exposto no Capítulo 1, Seção I.2.C). Retomando a classificação proposta naquele momento, há três níveis de apresentação do diagrama de um diálogo: (i) O nível das proposições, em que os elementos básicos do diagrama são premissas e conclusões; (ii) o nível da argumentação, em que os elementos básicos do diagrama são os argumentos; e (iii) o nível do problema, em que os elementos básicos apresentados são as questões. O nível das proposições é o mais detalhado, o dos argumentos é intermediário e o das questões é o menos detalhado.

As discussões sobre a responsabilização administrativa e civil do Estado e dos militares serão apresentadas apenas no nível do problema, com identificação das principais questões envolvidas. O mesmo vale para as discussões sobre a verdade histórica e a preservação da memória. No entanto, o diagrama será acompanhado de explicação e desenvolvimento textual.

Apresentaremos o diagrama no nível das proposições e da argumentação apenas para parte do debate sobre a responsabilização penal dos militares. Mais especificamente, as questões sobre (a) se houve anistia dos militares (discussões da correta interpretação e da invalidade da anistia) e (b) se há retroatividade na hipótese de iniciar hoje a persecução penal dos militares. As discussões penais restantes serão apresentadas como as demais, apenas no nível do problema e acompanhadas de explicação textual.

É nas discussões sobre a responsabilização penal, especialmente naquelas diagramadas no nível das proposições, que fica mais evidente que um diálogo está acontecendo. Por isso, em sua apresentação textual, convencionamos que os dois lados do diálogo seriam chamados de Pró-Militares, para os que advogam que eles não deveriam ser responsabilizados, e Contra Militares, para os que defendem justamente o contrário. Isso não significa que uma pessoa que defenda quaisquer desses argumentos tenha uma posição política ou jurídica pró-militar ou contra militar em qualquer situação. 
O diálogo deste Mapa é uma disputa, pois cada parte sustenta tese contrária a da outra (e não apenas duvida). Classifica-se ainda como um diálogo de persuasão ${ }^{84}$. Portanto, busca a melhor resposta e funciona por meio da argumentação racional (convencimento com base em premissas já aceitas e argumentos estruturalmente corretos). Os participantes (Pró-Militares e Contra Militares) agem por meio de turnos, e, para facilitar a exposição, permitimos que fossem oferecidos vários argumentos ou ataques a cada intervenção.

O conjunto de regras que governa o diálogo e a resolução da disputa pode ser chamado de protocolo de disputas. No presente caso, o protocolo geral está estabelecido no parágrafo anterior. As discussões sobre a correção dos argumentos se valem de todo o instrumental que a Teoria da Argumentação tem a oferecer, especialmente dos esquemas de argumentos, que também podem ser vistos como parte do protocolo (uma vez que o diálogo de persuasão exige argumentação estruturalmente correta).

Estabelecido o protocolo da disputa e delimitado o nível de detalhamento do Mapa, cabem mais algumas considerações acerca de sua elaboração.

O Mapa Argumentativo aqui apresentado não se refere a um diálogo real que tenha ocorrido, mas a uma discussão ideal construída pelo autor: a discussão que contribui o melhor possível para buscar a melhor resposta. O formato do diálogo de persuasão entre duas partes apresenta vários ganhos. Ajuda a desenvolver o debate no sentido da melhor resposta por meio da identificação dos argumentos e do seu posicionamento relativo aos outros argumentos, da avaliação dos argumentos e da identificação dos maiores pontos de tensão do diálogo. As bases das justificativas apresentadas são expostas com uma clareza que não se encontra comumente nos textos. Em complemento às vantagens do diálogo, a representação no diagrama facilita a sua visualização.

A maior dificuldade na elaboração do mapa residiu na identificação e organização dos argumentos esparsos a fim de transformá-los em um diálogo único com sentido. Primeiro, porque faltava uma estrutura geral para saber onde posicionar cada discussão dentro do debate maior. Segundo, porque os textos estudados não se apresentavam como

${ }^{84}$ Vide Capítulo I, Seção I.1.E. 
diálogos e pecavam pela falta de clareza na argumentação. Por vezes não havia sequer clareza quanto às teses que eram defendidas.

Um aparte merece ser feito quanto ao STF e à ADPF 153. Apesar de o julgamento ter sido feito em plenário, não houve diálogo adequado pois a existência do colegiado não costuma ser aproveitada para o desenvolvimento de debates em razão de outras características institucionais do Tribunal. A possibilidade de votar em um sentido ou noutro, sem ter de necessariamente enfrentar a argumentação dos outros ministros já diminui as potencialidades do diálogo ${ }^{85}$. Tal efeito negativo é agravado pelo fato de cada Ministro poder votar em separado, dificultando que seja estabelecido um raciocínio único partilhado a justificar a decisão (uma ratio decidendi). O que se verifica é que frequentemente os votos não "conversam" entre si, mesmo quando são dados no mesmo sentido. As discussões, quando existem, nem sempre fazem parte dos acórdãos. Assim, apesar da ADPF 153 ser importante, o Mapa Argumentativo aqui apresentado não é um mapa das discussões travadas durante seu julgamento.

Dado que o Mapa Argumentativo retrata uma discussão idealizada pelo autor, fica evidente que há considerável esforço de reconstrução de argumentos e, por consequência, muitas escolhas envolvidas no processo. Por exemplo, há dúvidas sobre a interpretação dos textos a serem reconstruídos; proposições podem ser escritas de várias formas; argumentos por vezes podem ser divididos em mais argumentos; e ataques representados por exceções que cortam o link inferencial poderiam ser representados como a identificação e subsequente ataque a premissas ocultas.

Como o objetivo é a elaboração de um mapa ideal e não a discussão dos limites e problemas da reconstrução, os raciocínios empregados nas inúmeras reconstruções não serão mostrados. Aliás, pelo fato de o mapa ser construído a partir de muitos textos e não

\footnotetext{
${ }^{85}$ Para essa observação nos inspiramos na crítica de Waldron ao modelo institucional em que os juízes podem simplesmente votar em um sentido ou em outro. Segundo o autor, se a decisão não será sustentada por um raciocínio, mas baseada somente em um voto, melhor seria deixar que o assunto fosse decidido democraticamente pela população, atendendo ao princípio majoritário. Sem entrar no mérito da crítica de Waldron, nos interessa destacar que a possibilidade de votar desincentiva o juiz, em alguma medida, a raciocinar no sentido de buscar a melhor resposta. WALDRON, Jeremy The core of the case against judicial review. 115 Yale L.J., 2006, p.1346-1406.
} 
de um diálogo real, tal tarefa, além de pouco útil, seria supra-hercúlea. Quanto às escolhas na redação e organização das premissas, importante pontuar que nem sempre os argumentos serão divididos tanto quanto possível. O excesso de argumentos para indicar cada inferência tornaria o mapa excessivamente complexo e inflado, dificultando a sua compreensão e visualização. Assim, haverá argumentos incompletos (entimemáticos), mas todas as proposições e inferências controversas ou importantes estarão devidamente representadas.

Apesar de ser ideal, o Mapa é limitado pela discussão real. De um lado, porque ainda que existam contribuições do autor à discussão, elas são limitadas. De outro, porque a discussão ideal é uma tentativa de mostrar a discussão real sob a melhor luz possível acrescida de desenvolvimentos do autor e não a construção de uma discussão completamente nova e independente. A discussão ideal, portanto, é parcialmente dependente da discussão real.

O Mapa, mesmo na sua parte mais detalhada, é por vezes incompleto. Há caminhos de argumentação que para serem explorados dependeriam de maiores estudos e pesquisas sobre temas diversos. Também há questões que só poderão ser resolvidas com casos individuais em que se busque a responsabilização de um militar determinado. Sempre que essas lacunas estiveram presentes, buscamos indicá-las de maneira clara.

Vale apontar ainda que na elaboração do Mapa foi feito um esforço para que as proposições que compõem os argumentos fossem as mais sintéticas e claras possível, objetivando que pudessem ser compreendidas por alguém sem formação jurídica. De qualquer modo, a apresentação do diagrama também será acompanhada de explicações textuais, mas a ideia é que ele possa ser completamente inteligível por si só, ao menos para alguém que possua alguma familiaridade com diagramas e teoria da argumentação.

\section{Mapa Argumentativo}

O Mapa Argumentativo geral da discussão sobre a responsabilização dos militares e do Estado pelos assassinatos, torturas e desaparecimentos forçados, bem como sobre os meios de descobrir a verdade histórica e preservar a memória segue abaixo: 


\section{Responsabilizacão}

I.1 O Direito (Processo Judicial/Administrativo) como meio de responsabilização

\section{I.1.A Penal (Militares)}

\section{I.1.A.1 Objeções Filosófico-Jurídicas}

- Finalidades da Pena: A punição dos militares atende às finalidades da pena? (retribuição, prevenção geral positiva, prevenção geral negativa, prevenção especial negativa)

\section{I.1.A.2 Objeções Jurídicas Abstratas}

- Anistia: Houve anistia dos militares (Lei 6.683/1979)?

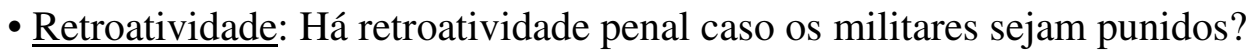

I.1.A.3 Objeções Jurídicas Concretas

- Prescrição: Houve prescrição dos crimes cometidos pelos militares?

- Provas e Responsabilidade Individual: É possível, após tanto tempo, provar de maneira satisfatória a participação dos militares e responsabilizá-los penalmente nos casos concretos?

I.1.A.4 Considerações Politicas, Morais e de Justiça ${ }^{86}$

- Questão Preliminar: As objeções políticas devem ser levadas em consideração na tomada de decisão jurídica?

- Política X Direito (1): Ainda que seja juridicamente possível punir penalmente, é a melhor escolha?

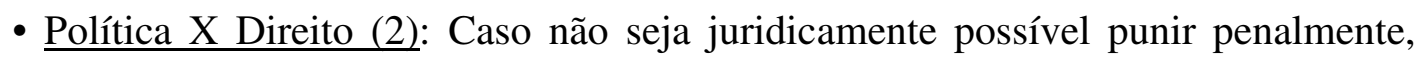
deve haver punição penal ainda assim?

\section{I.1.B Administrativa (Estado) \\ I.1.C Cível (Militares e Estado)}

\section{I.2 Outros meios de responsabilização}

\section{I.2.A Moral}

\section{I.2.B Social/Política}

\footnotetext{
${ }^{86}$ Os mesmos questionamentos que são feitos em relação à política podem ser feitos para a Moral e para a Justiça.
} 
I.3 Quanta responsabilização é suficiente? (Qual o melhor meio de responsabilizar dentre os meios à disposição?)

\section{Verdade e Memória}

II.1 Qual o melhor meio para descobrir a verdade sobre o período do regime militar?

II.1.A O Direito como meio para descobrir a verdade

II.1.A.1 Considerações Preliminares

- Direito à Verdade: Há um direito à verdade?

- Processo Judicial: O processo judicial é uma maneira eficaz de buscar a verdade? Há dificuldades jurídico-processuais que prejudicam a busca da verdade pelo processo judicial? Diferentes regimes processuais prejudicam a busca de maneiras diferentes (civil, penal)?

- Comissões: As Comissões da Verdade são uma maneira eficaz de buscar a verdade?

II.1.B Problemas na busca pela verdade

- Problema Teórico: Existe uma verdade a ser buscada?

- Problema Fático: Há dificuldades fáticas que impedem a busca da verdade?

II.2 Qual o melhor meio para preservar a memória do que aconteceu de grave no regime militar?

$* * * * * * * * * * * * * * * * * * * * * * * * * * * * * * * * * * * * * * * * * * * * * * * * * * * *$

Os mapas mais detalhados, no nível dos argumentos e das proposições estão no Apêndice IV. Os textos abaixo referente aos itens I.1.A.2 (Anistia, Retroatividade) devem ser lidos como um acompanhamento dos diagramas do Apêndice IV. Trataremos de cada item do mapa nas subseções a seguir. Para manter o foco do trabalho nos problemas jurídicos não foram tratadas as questões dos pontos I.1.A.4 ("Considerações Políticas, Morais e de Justiça”), I.2 (“Outros meios de responsabilização”) e I.3 ("Quanta responsabilização é suficiente?"). 


\section{$\underline{\text { Responsabilizacão (I) }}$}

Como se pode verificar no Mapa, há vários debates sobre a responsabilização dos militares e do Estado, de acordo com as suas diferentes formas. A responsabilização jurídica é apenas um meio, pois existem ainda a responsabilização moral e a responsabilização social e política. Dentro da responsabilização jurídica, existem a responsabilização penal (aplicável apenas aos militares), administrativa (aplicável apenas ao Estado) e civil (aplicável aos dois).

Para cada meio de responsabilização debate-se se ele é realmente possível, de que forma pode ser realizado e a justificativa para empregá-lo, observando-se as consequências da sua utilização. Após a resposta a essas questões sobre cada meio de responsabilização isoladamente, surgem as questões sobre como escolher dentre os meios de responsabilização à disposição: qual o melhor dos meios e até que ponto eles podem ser cumulativos para atingir um nível ótimo de responsabilização.

Por meio dessa breve apresentação do Mapa amplo, fica evidente a grandiosidade e dificuldade da discussão. A discussão real tendeu a se desenvolver mais nos pontos específicos sobre alguns meios de responsabilização, havendo meios que foram pouco discutidos. Além disso, a discussão sobre a escolha dos meios é desorganizada e incipiente.

O meio de responsabilização de maior destaque no debate é o Direito Penal e, por isso, trataremos dele primeiro.

\section{Responsabilização Jurídico-Penal (I.1.A)}

As torturas, assassinatos e desaparecimentos forçados ocorridos são eventos graves, e a ideia de que se trata de crimes logo surge. Associado ao crime vem a ideia de pena. Contudo, houve um processo político de anistia e muito tempo se passou desde o regime militar, o que levanta dúvidas sobre a possibilidade jurídica da responsabilização penal e se as justificativas jusfilosóficas para a aplicação da pena ainda podem ser sustentadas diante das peculiaridades do caso. O debate real se constrói justamente em torno das objeções à responsabilização penal dos militares. 
Assim, no Mapa ideal que elaboramos, organizamos a discussão a partir do que identificamos como as principais questões que guiam o debate. O Mapa foi organizado por ordem de prejudicialidade das questões. Uma questão é prejudicial quando, a depender da resposta que se dá a ela, a pergunta ou conjunto de perguntas subsequentes perde o sentido ou se torna inútil. Ou seja, neste debate uma questão só vale ser enfrentada caso a anterior tenha sido adequadamente respondida.

O primeiro conjunto de objeções é denominado filosófico-jurídico e diz respeito às finalidades da pena. A objeção é a de que mesmo sendo possível aplicar a pena, se ela não puder cumprir nenhuma das finalidades a que se destina, o melhor seria deixar de aplicá-la.

$\mathrm{Na}$ sequência, temos as objeções jurídicas abstratas, isto é, impedimentos à responsabilização penal dos militares que a princípio independem dos detalhes sobre a ação concreta de um militar no tempo e no espaço. A primeira é a anistia da Lei $\mathrm{n}^{\circ}$ 6.683/1979. Se houve anistia dos militares não há crime, portanto não é mais necessário discutir qual o tipo de crime, nem a contagem do prazo prescricional, nem as provas, as ações dos responsáveis, nada. A questão está sendo colocada como "Houve anistia dos militares?", ou seja, um questionamento da premissa comumente aceita de que os militares foram anistiados do mesmo modo que os militantes de esquerda contrários ao governo. Os principais documentos em que se trava essa discussão são a sentença do Caso Gomes Lund na $\mathrm{CIDH}$ e as peças e acórdão da $\mathrm{ADPF}$ 153, com destaque para a petição inicial redigida por Fábio Konder Comparato e Maurício Gentil Monteiro e para o voto do Ministro Eros Grau.

A segunda objeção jurídica abstrata discute se há retroatividade penal vedada pelo Direito em caso de responsabilização. A irretroatividade das leis penais é vista como uma importante garantia do Estado de Direito e da segurança jurídica, sendo uma regra importante no sistema constitucional brasileiro (assim como em muitos outros). Por ter existido uma anistia, ainda que apenas de fato, não estaríamos fazendo a lei retroagir para condenar penalmente os militares? A questão é fundamental no debate. 
Caso todos os empecilhos acima sejam superados, encontramos o grupo de objeções jurídicas concretas, isto é, aquelas que dependem da análise de fatores concretos de cada caso para verificar se são efetivos impedimentos à responsabilização penal. Aqui se encontra a questão da prescrição da pretensão punitiva do Estado. Se os crimes ocorreram há tanto tempo, não estariam prescritos? Isso depende de se discutir a prescritibilidade dos crimes, o prazo prescricional, os marcos de contagem e as hipóteses de interrupção e suspensão. As discussões realizadas nos autos do processo $\mathrm{n}^{\circ} 0004204-$ 32.2012.4.03.6181, no qual o MPF ofereceu denúncia contra Carlos Brilhante Ustra e Dirceu Gravina são os principais documentos.

Além da questão da prescrição, discute-se nas objeções jurídicas concretas a possibilidade de colherem-se provas suficientes e de individualizar a conduta de eventuais réus a fim de realizar a condenação penal. De nada adiantaria superar todas as difíceis preliminares acima se essa tarefa não pudesse ser realizada.

Em cada uma das discussões, sempre que relevante, foram tratados diferentemente os casos de assassinato, tortura e desaparecimentos forçados, pois cada uma dessas situações fáticas pode apresentar um tratamento jurídico diferente. Além disso, foi dado maior destaque à situação fática do Caso da Guerrilha do Araguaia, tratado em maior detalhe acima e caso principal do presente estudo. Por fim, apenas as discussões sobre a anistia e a retroatividade foram diagramadas em maior detalhe, no nível da argumentação e proposições.

\section{Finalidades da Pena (I.1.A.1)}

As diferentes teorias sobre a pena apontam cinco justificativas diferentes para sua aplicação $^{87}$ :

\footnotetext{
${ }^{87}$ Para um breve resumo sobre as diferentes justificativas da pena ver PÜSCHEL, Flávia Portella. A Função Punitiva da Responsabilidade Civil no Direito Brasileiro: Uma Proposta de Investigação Empírica. Revista Direito GV nº6, jul-dez 2007, p. 17-36; GÜNTHER, Klaus. Crítica da Pena I (2004). Revista Direito GV no 4 , jul-dez 2006, p. 187-203.
} 
(i) Retribuição: O fundamento da pena é o ilícito, pune-se porque se cometeu um ilícito e somente por isso. A punição é um fim em si mesmo, deve-se retribuir o mal pelo mal.

(ii) Prevenção Geral Negativa: O fundamento da pena é a sua utilidade. Punese como exemplo, para que ninguém cometa o mesmo ilícito.

(iii) Prevenção Especial Negativa: O fundamento da pena é a sua utilidade. Pune-se para que aquele que cometeu o ilícito não volte a cometê-lo.

(iv) Prevenção Geral Positiva: O fundamento da pena é a garantia dos pressupostos de interação social. Pune-se e declara-se o crime para confirmar as expectativas daqueles que confiam na norma jurídica, da sociedade em geral.

(v) Prevenção Especial Positiva: O fundamento da pena é a garantia dos pressupostos da interação social. Pune-se e declara-se o crime para corrigir aquele que cometeu o ilícito e levá-lo ao caminho da legalidade.

A dogmática penal brasileira reconhece tanto a retribuição como a prevenção como justificativas para a pena no ordenamento jurídico brasileiro. A partir desse quadro, podemos analisar cada uma das cinco justificativas para verificar se elas se sustentam no caso de punição dos militares. Quanto à retribuição, nos parece que a punição é justificável. Caso se entenda que realmente os assassinatos, torturas e desaparecimentos forçados foram ilícitos isso é suficiente para punir. Afinal, a ideia é punir somente porque houve um ilícito, sendo desnecessária qualquer justificativa adicional.

Quanto à prevenção geral negativa, isto é, punir para que ninguém faça o mesmo, a justificativa pode parecer mais fraca. O contexto do regime militar não parece que irá se repetir e, assim, é improvável que esta punição seja um desestímulo a alguém. No entanto, ainda que a possibilidade seja remota, há a chance de futuramente ocorrer um contexto similar de repressão de particulares pelo poder estatal. A punição pelos abusos, apesar de 
tardia, mandaria a mensagem de que existem limites para os agentes estatais de repressão e que as suas ações têm consequências.

Quanto à prevenção especial negativa, punir para que quem cometeu o ilícito não volte a cometê-lo, a justificativa não parece se sustentar. Os agentes da repressão que cometeram os assassinatos, torturas e desaparecimentos forçados ou morreram ou já estão muito velhos (a maioria com mais de 70 anos) ${ }^{88}$. É muito difícil imaginar uma situação em que esses agentes tentem repetir essas ações. Assim, se não há risco de que o ilícito volte a ser cometido independentemente da punição, ela é inútil do ponto de vista da prevenção especial negativa.

Quanto à prevenção geral positiva, punir para confirmar as expectativas daqueles que confiam na norma jurídica, a justificativa também parece possível a princípio. Se realmente houve crimes a serem punidos, e eles ainda são puníveis (o que depende de superar as questões sobre anistia, prescrição, etc.), a efetiva aplicação da pena é o que garantirá a confiança da população nas normas jurídicas. Importante notar, contudo, que se houver algum impedimento como a prescrição, não deve haver a punição, pois a população também deve poder confiar nas limitações ao poder punitivo do Estado, que são normas jurídicas tanto quanto aquelas que estabelecem os crimes e as penas.

Não punir, no entanto, não é o mesmo que dizer que não houve crime. O Estado pode deixar de punir, por exemplo, quando o fato não for considerado crime (que é o efeito de uma anistia), ou quando houver a prescrição, extinguindo a pretensão estatal de punibilidade. Uma interpretação que se pode dar à prevenção geral positiva é que ela se importa não apenas com a punição, mas com a declaração de que uma determinada conduta é considerada criminosa. Afinal, essa declaração serve para mostrar para a população o que se entende por ilícito em determinada sociedade, relembrando os valores em que essa sociedade se baseia Assim, a declaração de que houve crime, mesmo que não haja punição, pode atender à prevenção geral positiva ${ }^{89}$.

\footnotetext{
${ }^{88}$ Neste sentido ver SWENSSON JUNIOR, Lauro Joppert et al. Justiça de Transição no Brasil: Direito, Responsabilização e Verdade. São Paulo: Saraiva, 2010, p.51.

${ }^{89}$ Para uma defesa da possibilidade da mensagem de que um ato é ilícito ser passada à sociedade independentemente da pena ou da punição ver GÜNTHER, Klaus. Crítica da Pena I (2004). Revista Direito GV no 4, jul-dez 2006, p. 201.
} 
Por fim, quanto à prevenção especial positiva, punir ou declarar o crime para levar aquele que cometeu o ilícito ao caminho da legalidade e à ressocialização, a justificativa também não parece se sustentar. Os antigos agentes da repressão que continuam vivos permanecem integrados à sociedade de alguma maneira. Com efeito, olhando-se para a história é difícil dizer que eles foram marginalizados. Após o fim do regime militar, muitos dos acusados de torturadores chegaram até mesmo a ocupar cargos de destaque em diversas esferas de poder, como o Coronel Carlos Alberto Brilhante Ustra, que em 1985 era adido militar da embaixada brasileira em Montevidéu. ${ }^{90}$ Vale apontar, no entanto, que, após pressões, alguns chegaram a ser exonerados de seus cargos por conta de denúncias de tortura, como no caso citado acima do Coronel Armando Avólio Filho, adido militar da embaixada brasileira na Inglaterra.

Assim, de um lado as ideias de prevenção especial negativa e positiva não parecem oferecer uma justificativa para a punição dos militares. De outro, as teorias da retribuição ${ }^{91}$ e da prevenção geral negativa e positiva, aparentam fornecer uma justificativa adequada para que a punição, ou pelo menos a declaração da existência de crime ocorra.

\section{$\underline{\text { Anistia (I.1.A.2) }}$}

Costuma-se assumir que os militares foram anistiados pela Lei 6.683/1979. Essa proposição é questionada de duas maneiras. Em primeiro lugar, argumenta-se que a correta interpretação da Lei da Anistia leva à conclusão de que os militares não foram anistiados. Em segundo lugar, ainda que a Lei da Anistia efetivamente anistiasse os militares tal anistia seria inválida e não poderia gerar efeitos jurídicos.

Em contrapartida, para contornar esses dois questionamentos, são realizadas duas alegações. Haveria uma guerra de fato e de direito entre os militares e a oposição, justificando a intepretação da anistia recíproca e afastando qualquer argumento de

\footnotetext{
${ }^{90}$ Conforme MEZAROBBA, 2006, p. 72/73.

${ }^{91}$ Ainda que existam severas críticas à teoria da retribuição como fundamento para aplicação de penas, a dogmática penal brasileira e a jurisprudência continuam aceitando a retribuição como uma justificativa para a punição. Ou seja, do ponto de vista do Direito Brasileiro, a retribuição ainda é uma justificativa aceita. Para críticas à retribuição como fundamento da punição ver, por exemplo, GÜNTHER, Klaus. Crítica da Pena I (2004). Revista Direito GV no4, jul-dez 2006, p. 187-203; GÜNTHER, Klaus. Crítica da Pena II (2005). Revista Direito GV nº5, jan-jun 2007, p. 137-149.
} 
invalidade. A anistia dos militares teria sido "constitucionalizada" pelo Art. $4^{\circ}$ da EC 26/1985. Cada uma dessas discussões será analisada em separado, mostrando-se os diversos argumentos que as compõem.

\section{Correta Interpretação da Lei da Anistia}

O mapa foi construído a partir de discussões que surgiram do seguinte argumento:

\section{Argumento A (Anistia dos Militares) (Geral)}

P1 O Art. $1^{\circ}$, caput da Lei de Anistia diz que os crimes conexos aos crimes políticos são anistiados.

P2 Os crimes praticados pelos militares foram conexos.

Cl Os militares foram anistiados.

A afirmação de que os crimes praticados pelos militares foram conexos $(P 2)$ costuma receber duas justificativas diferentes. A primeira é de que há conexão, pois, nos termos do Artigo 76, I do Código de Processo Penal foram praticados crimes uns contra os outros entre militares e opositores do regime. A segunda justificativa é a de que são considerados conexos os crimes praticados por motivação política, nos termos do $\S 1^{\circ}$ do Artigo $1^{\circ}$ da Lei de Anistia.

Além de contestar as justificativas acima, os Contra Militares buscam afastar a afirmação de que os crimes praticados pelos militares foram conexos, defendendo que essa proposição não se sustenta perante critérios técnicos de conexão previstos na legislação penal.

\section{Conexão por crimes praticados uns contra os outros}

A primeira justificativa para a conexão é a de que ela existe com base no Artigo 76, I do Código de Processo Penal, pois foram praticados crimes uns contra os outros entre militares e opositores do regime. 
Os Contra Militares atacam esse argumento com outros dois argumentos, uma exceção e um ataque à premissa. Como exceção, explicam que a regra do Art. 76, I do Código de Processo Penal é de cunho processual, não podendo ser utilizada para interpretar o conceito de conexão da Lei de Anistia, que é material. De outro lado, alegam que os crimes políticos não são praticados contra pessoas, mas contra a ordem política. Portanto, não poderiam ter cometido crimes contra os militares e não haveria crimes praticados uns contra os outros.

Em resposta, os Pró-Militares alegam que há grupos de oposição que praticaram crimes comuns além de políticos, notadamente os que ofereceram resistência armada ao regime militar.

$\mathrm{Na}$ condição de analistas, cabe primeiro observar que mesmo que este último argumento dos Pró Militares seja verdadeiro, ele apenas justifica a anistia dos militares para os casos em que houve crimes comuns praticados uns contra os outros. Nem todos os opositores do regime que sofreram torturas, foram assassinados ou desapareceram cometeram crimes comuns contra os militares. Ou seja, basear a anistia dos militares na conexão por crimes uns contra os outros limitaria a anistia apenas a parte dos crimes de uma parte dos militares.

De qualquer modo, a exceção apresentada pelos Contra Militares (conexão processual) nesse caso nos parece suficiente para afastar completamente a justificativa da anistia com base nos crimes praticados uns contra os outros. Não encontramos argumento contrário a infirmar essa conclusão.

\section{Conexão por Motivação Política}

A segunda justificativa dos Pró-Militares é baseada na "motivação política" prevista no $\S 1^{\circ}$ do Artigo $1^{\circ}$ da Lei de Anistia. Contudo, existem dúvidas sobre o significado jurídico de "motivação política". Os Contra Militares dizem que o sentido de "motivação política" nesse dispositivo é a motivação de contestar o regime político vigente. De outro lado, os Pró-Militares dizem que a expressão "motivação política" também inclui a motivação de defender e reafirmar o regime político vigente, que seria a 
motivação dos militares. Não haveria razão para descartar o caráter político da motivação dos militares. Mesmo a tortura, o assassinato e os desaparecimentos forçados poderiam ser politicamente motivados.

Para podermos decidir qual é a melhor interpretação da expressão "motivação política", devemos resgatar o contexto histórico e legislativo da promulgação da Lei de Anistia, exposto acima. Em primeiro lugar, a Lei de Anistia fazia parte de um momento de reabertura política gradual e tinha por objetivo avançar politicamente neste sentido. Se a ideia de base da Lei de Anistia era a reabertura política, a interpretação no sentido de anistiar os que contestaram o regime político faz sentido. De outro lado, privilegiar a reafirmação do regime, por meio da anistia dos atos que o defenderam, não guarda qualquer relação com esse objetivo.

Contra essas alegações, os Pró-Militares podem arguir que, dependendo da conceituação que se der a crime político, não faria sentido incluir no texto da lei a expressão "motivação política", exceto para beneficiar os militares que reafirmaram o regime político (SWENSSON JR., pg. 39/40, rodapé 52). Segundo esse argumento, se crime político é aquele que contesta o regime, não se pode dizer que a "motivação política" seja somente contestar o regime, pois a expressão seria inútil, e a lei não possui palavras inúteis.

Em resposta, os Contra Militares podem apontar que, justamente pela falta de clareza sobre os crimes que poderiam ser considerados políticos, a expressão "motivação política" como contestação do regime ganha sentido. Ela teria capacidade de abranger qualquer crime praticado por aqueles que contestaram o regime (excetuados os crimes do mencionado $\S 2^{\circ}$ ) como um crime conexo. Assim, a expressão teria sido introduzida a fim de garantir a anistia dos vários crimes cometidos pelos opositores do regime, o que faz sentido com o objetivo da Lei de Anistia no contexto de reabertura política gradual.

Em segundo lugar, dizer que qualquer ato violento como tortura e assassinato pode fazer parte do sentido de "motivação política" não se coaduna com o texto da Lei, nem com as razões oferecidas pelo próprio governo na defesa de seu texto. $\mathrm{O} \S 2^{\circ}$ do Artigo $1^{\circ}$ da Lei de Anistia exclui expressamente os "condenados pela prática de crimes de 
terrorismo, assalto, sequestro e atentado pessoal". Como visto, tal exclusão foi defendida pelo governo, alegando que não se poderia aceitar a anistia de atrocidades cometidas pela oposição, chamadas pelos militares de "crimes contra a humanidade". Seria completamente incoerente permitir que torturas, assassinatos e desaparecimentos forçados cometidos pelos militares fossem anistiados ao mesmo tempo em que houvesse a intenção de excluir os atos violentos dos opositores do regime precisamente pelo seu caráter violento e atentatório contra a pessoa humana.

Não se pode esquecer que, na prática, houve alguns opositores do regime que se beneficiaram da Lei de Anistia mesmo tendo cometido crimes de terrorismo, assalto, sequestro e atentado pessoal. Isso porque o texto do $\S 2^{\circ}$ do Artigo $1^{\circ}$ da Lei de Anistia excluía expressamente apenas os "condenados" pela prática de tais crimes, deixando de fora os que ainda não haviam sido condenados. A utilização da expressão "condenados" foi alvo de críticas durante o processo legislativo (MEZAROBBA, p.41/42), sendo suas consequências (a interpretação de que os não condenados seriam beneficiados) consideradas uma injustiça. O texto final, entretanto, foi aprovado sem alteração nesse ponto. O governo simplesmente insistiu que não podia perdoar os "crimes contra a humanidade" cometidos pela oposição armada (MEZAROBBA, p.39 e p.46).

Como relatado, outros criminosos condenados, aos quais não se aplicou a Lei de Anistia, foram beneficiados por um indulto concedido mais tarde, por meio do Decreto 84.223 de 20 de novembro de 1979. Por meio deste indulto, muitos tiveram suas penas diminuídas, o que resultou na liberação imediata de muitos presos. Destaque-se que o indulto sequer perdoou completamente os atos praticados, como o fez a anistia, mas apenas diminuiu as penas. Os criminosos não deixaram de pagar (ainda que menos) pelos crimes que haviam cometido.

O indulto é uma prática governamental comum, sendo geralmente concedido em novembro ou dezembro, próximo do Natal, motivo pelo qual é conhecido como "indulto de Natal". O governo militar nunca deixou de realizar o indulto durante todo o regime, mas sempre excluía parte condenados dos benefícios do indulto por causa do tipo de crime que haviam cometido, aí incluídos os crimes contra a segurança nacional. O indulto do Decreto 84.223/1979 foi diferente dos outros por excluir apenas os envolvidos com tráfico de 
entorpecentes (Artigo $6^{\circ}$ ), permitindo que os benefícios se estendessem aos outros condenados, inclusive àqueles que respondiam por crimes contra a segurança nacional. Apesar de o indulto ter beneficiado presos políticos, ele não foi concedido apenas para eles.

Assim, apesar do defeito da lei que permitiu que alguns não condenados se beneficiassem da anistia, o intuito defendido, e que permaneceu no texto, era o de que os crimes considerados "contra a humanidade" deveriam ser excluídos. Por sua vez, o indulto, que extingue a pretensão de punibilidade e não se confunde com a anistia, que extingue o crime, não eliminou as penas dos condenados, tendo-lhes apenas reduzido, e não foi direcionado apenas aos criminosos políticos.

Para além da interpretação contextual da Lei de Anistia, a jurisprudência do $\mathrm{STF}^{92}$ em casos de extradição, interpretando o Art. $77, \S 1^{\circ}$ da Lei $6.815 / 1980$, reforça o argumento de que nem todo crime pode ser considerado político ou realizado por motivação política. O entendimento, que não possui a princípio limitações aos casos de extradição, é de que o caráter político de um crime deve ser apreciado no caso concreto, levando em consideração dois critérios: (i) a preponderância do fator político no contexto da conduta criminosa, que contribui para a caracterização do crime político; e (ii) a atrocidade dos meios, que contribui para a descaracterização do crime político. (ADPF 153, p.118/127, Voto Min. Lewandowski)

A partir dessa jurisprudência poderiam ser desenvolvidos argumentos em dois sentidos: (i) a execução, a tortura e o desaparecimento forçado são meios tão atrozes que não poderiam jamais constituir crimes políticos; ou, no mínimo, (ii) a conclusão pelo caráter político do crime e a sua consequente inclusão no rol de benefícios da anistia deveria ser precedida da análise de cada caso individualmente.

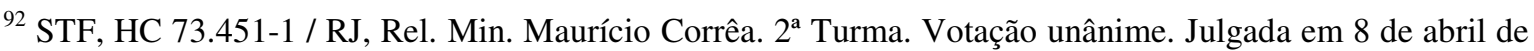
1997; (Caso Norambuena) STF, Extradição 855-2 / República do Chile, Rel. Min. Celso de Mello. Plenário. Votação unânime (parte dos pedidos) e votação por maioria (parte dos pedidos). Julgada em 26 de agosto de 2004; e (Caso Battisti) STF, Extradição 1.085 / República Italiana, Rel. Min. Cezar Peluso. Plenário. Votação por maioria. Julgada em 16 de dezembro de 2009. Todas as decisões disponíveis em http://www.stf.jus.br, último acesso em 12 de dezembro de 2012.
} 
Interessante notar que a argumentação a partir da jurisprudência do STF em casos de extradição pode permitir não apenas a avaliação das atrocidades cometidas pelos militares, mas também daquelas cometidas pela parte da oposição armada que foi beneficiada (como o referido atentado do Aeroporto Guararapes, cuja autoria alguns atribuem ao grupo Ação Popular). Afinal, para que sejam anistiados, os crimes da oposição armada também têm de ser considerados crimes políticos e não serem excluídos por meio do Art. $1^{\circ}, \S 2^{\circ}$. Assim, teriam de ser avaliados pelos critérios de preponderância e atrocidade.

Em suma, a linha de argumentação exposta se baseia em uma reinterpretação de crime político ou com motivação política. Historicamente, a interpretação ampla que se deu ao conceito tal qual utilizado na Lei de Anistia ignorou os critérios de preponderância e atrocidade dos meios e acabou por considerar inclusos na anistia todos os crimes atrozes, fossem dos militares, fossem da oposição armada. Tal interpretação, no entanto, é incoerente com as razões oferecidas para a elaboração da Lei de Anistia, com seu texto e com a jurisprudência do STF.

No sentido contrário, para justificar a interpretação de que os militares foram anistiados, afastando todas as razões dos Contra Militares, há o famoso argumento da negociação política. Segundo ele, foi realizado um acordo político para que fossem anistiados tanto os militares que tivessem cometido assassinato, tortura e desaparecimento forçado, quanto os opositores do regime que tivessem realizado a luta armada. A Lei de Anistia deveria ser interpretada a partir deste acordo político, que traduziria a vontade do legislador. Tal argumento foi utilizado principalmente pelo Ministro Eros Grau no julgamento da ADPF 153. Há várias críticas a esse argumento.

Em primeiro lugar, em uma negociação se pressupõe que ambas as partes estejam em paridade de armas, ou seja, que ambas tenham poderes equivalentes. No caso, vários fatores mostram que não havia paridade de armas. A iniciativa para a anistia de crimes políticos era prerrogativa exclusiva do Presidente (conforme o Art. 57, VI da Emenda Constitucional $n^{\circ}$ 01/1969), que era um militar. O projeto dependia de sanção presidencial para ser aprovado. Dos 41 senadores da ARENA que compunham a maioria do Senado, 21 
eram biônicos ${ }^{93}$. O regime de exceção instaurado pelos militares envolvia a possibilidade de cassação de deputados por atos de exceção, o que ocorreu várias vezes durante o regime militar.

A tramitação do projeto de lei também ajuda a revelar a falta de paridade de armas. Dentro e fora do Congresso Nacional realizaram-se críticas à falta de clareza do texto, que poderia ser utilizada para beneficiar os torturadores (MEZAROBBA, p. 42 e p.44). Tais críticas, assim como muitas outras a diferentes pontos do projeto, foram todas rejeitadas pelo governo militar, de acordo com a sua conveniência.

Além da falta de paridade de armas, não se verifica nos debates que levaram à edição da Lei de Anistia qualquer negociação efetiva, clara e aberta sobre a anistia aos militares. À época isso nem era pensável, pois apesar de todos saberem que as atrocidades existiam, o governo não as reconhecia. Como poderia haver uma negociação clara e aberta sobre o tema, se o governo não reconhecia clara e abertamente que os militares torturavam, assassinavam e faziam as pessoas sumirem? Simplesmente não poderia. Além disso, se realmente tivesse havido um "acordo político", ele teria constado claramente da lei que seria, afinal, o reflexo deste acordo.

Ao que tudo indica, a Lei de Anistia foi usada de modo sutil no processo de apagar as atrocidades cometidas pelo regime militar. Não é à toa que a anistia aos militares apenas foi tangenciada no debate, quase sempre na forma de críticas, e não constou de maneira expressa na Lei.

Exemplificando o processo sutil de construção da anistia dos militares, em 12 de dezembro de 1979, o então ministro da Justiça Petrônio Portella - um dos responsáveis pela elaboração do projeto de Lei da Anistia encaminhado pelo General Figueiredo ao Congresso Nacional - propôs ao Conselho de Defesa dos Direitos da Pessoa Humana que fossem examinadas apenas as violações presentes de direitos humanos, esquecendo-se as antigas. Com a aprovação dessa proposta, as investigações e denúncias de tortura, assassinato e desaparecimento foram arquivadas. Tal medida suscitou críticas da oposição

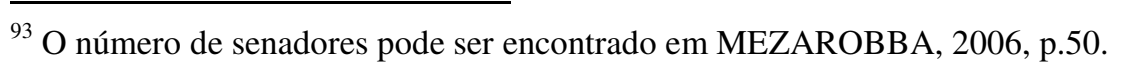


e afirmações de alguns que insistiriam nas suas denúncias, esperando que elas fossem devidamente apuradas com a redemocratização do país. (MEZAROBBA, p. 52/53)

Mas se não houve negociação, qual era o interesse dos militares em realizar a anistia? Primeiro, havia o contexto de reabertura política gradual. Diante das pressões internas e internacionais contra o regime de exceção que havia se instaurado, a abertura era um meio de prolongar a vida do regime, de mudá-lo para que continuasse existindo. Segundo, a anistia fazia parte de uma estratégia do governo militar para desagregar a oposição e enfraquecê-la. Por isso, em 20 de dezembro de 1979, foi restabelecido o pluripartidarismo. Esperava-se que, com a anistia, a volta de personalidades influentes em um regime pluripartidário contribuísse para criar vários partidos menores, desarticulados, sem força para fazer frente ao governo militar. (MEZAROBBA, p. 57/58)

Por fim, a própria noção de que houve a negociação de uma anistia recíproca entre militares e opositores do regime faz pouco sentido no caso. Essa ideia passa a errônea impressão de que existia unidade entre esses dois grupos e de que os seus representantes sentaram-se juntos, discutiram o assunto e concluíram que era melhor esquecer a luta armada dos opositores e as torturas e assassinatos dos militares. Não foi isso que aconteceu.

A oposição ao regime militar não era uma massa única, articulada e organizada. Como visto acima, havia um sem número de organizações com diferentes ideias, atuando de diferentes maneiras. Dentro dessas organizações seus membros também cumpriam papéis diferentes e agiam de modos diferentes. Assim, houve opositores que participaram da luta armada, que eram a minoria, e outros que não tinham nenhuma relação com os primeiros. Dada a falta de unidade da oposição, aqueles que pegaram em armas não podem ser vistos como uma espécie de "braço armado da esquerda"94.

As torturas, assassinatos e desaparecimentos não ocorreram apenas com participantes da luta armada. Assim, na suposta negociação política haveria opositores do regime que sofreram torturas ou que tiveram parentes e amigos assassinados ou desaparecidos, mas teriam trocado o perdão aos militares pela volta do exílio, pela

${ }^{94}$ Para a referência à ideia de um "braço armado" da esquerda, ver "Repressão e desenvolvimento: a modernização conservadora” em REIS, Daniel Aarão, 2012, p. 12-13. 
reintegração aos seus cargos públicos ou pelo perdão aos seus variados crimes de "subversão". Mesmo sem terem participado da luta armada, tais opositores do regime estariam dispostos a aceitar estes termos. Sem discutir a validade jurídica de uma negociação desta espécie, o que se aponta com esse argumento é a falta de verossimilhança de que alguma negociação tenha efetivamente ocorrido nesses termos.

A história mostra que a Lei de Anistia não foi negociada. A Lei de Anistia foi imposta pelo regime militar. Revela ainda que a anistia aos militares, supostamente prevista na Lei de Anistia, nunca foi efetivamente negociada de forma clara e aberta. Apenas tangenciou o debate na forma de críticas à obscuridade do texto, que permitiria interpretação no sentido de anistiar torturadores e outros. Coloca ainda em xeque a noção de que uma anistia recíproca possa ter sido negociada nos termos propostos. Assim, o argumento de que houve uma negociação política a justificar a anistia dos militares se apresenta como uma distorção histórica ${ }^{95}$.

A discussão pode ser apresentada resumidamente de outra maneira, como um conflito entre interpretações concorrentes. Pode-se dizer que os Pró-Militares defendem que a melhor interpretação se dá pela vontade subjetiva do legislador de anistiar os militares que cometeram excessos, sendo está última supostamente verificada no contexto histórico por meio de um acordo político. Os Contra Militares podem ser vistos como defendendo, em um nível mais amplo, uma interpretação histórica segundo a qual a anistia só serviu a quem buscava contestar o regime vigente. E ainda, em um nível mais específico, sem contrariar a interpretação histórica, uma interpretação sistemática de que as atrocidades não poderiam ser admitidas como crimes políticos. Esta última, sustentada no Art. $1^{\circ}, \S 2^{\circ}$ da Lei de Anistia, conjugada com as razões expostas no processo legislativo que justificaram sua inclusão e também na jurisprudência do STF. Essa interpretação sistemática manifestaria a vontade objetiva da lei de excluir os crimes violentos.

\footnotetext{
${ }^{95}$ Nesse sentido, escreve Glenda Mezarobba que "Como reza a tradição autoritária, praticamente não houve troca de ideias com a sociedade, tampouco com os potenciais beneficiários da legislação. (...) Sua escassa disposição para o diálogo tornar-se-ia evidente quando da apreciação das emendas ao projeto, no Congresso Nacional, e na votação da Lei de Anistia, com a ocupação das galerias por centenas de recrutas da Aeronáutica". MEZAROBBA, 2006, p.146.
} 
A interpretação dos Pró-Militares falha na falta de elementos fáticos a dar base para a ideia do acordo político e não encontra respaldo claro no texto legal. De outro lado, a interpretação dos Contra Militares confere maior coerência ao contexto político e ao ordenamento jurídico, harmonizando o texto da lei, as razões oferecidas no processo legislativo e a jurisprudência do STF.

Antes das conclusões sobre esse ponto, cabe uma observação geral. Eventuais argumentos baseados no Art. $4^{\circ}, \S 1^{\circ}$ da EC 26/1985 serão apresentados adiante. A maior parte das razões aqui apresentadas será aproveitada, pois há poucas diferenças relevantes para a discussão da interpretação correta do conceito de crime político ou motivação política, já que o texto da Emenda Constitucional permanece quase idêntico ao da Lei de Anistia $^{96}$. Os argumentos quanto à ausência de acordo político também se mantêm ao longo tempo, podendo ser questionado apenas o da falta de paridade de armas.

Do nosso ponto de vista, a melhor interpretação do significado da expressão "motivação política" é "motivação de contestar o regime político". Essa interpretação se adequa melhor ao contexto, enquanto a interpretação dos Pró Militares se baseia, em última análise, na ideia de que houve uma negociação política, o que não se sustenta. Além disso, permitir que a "motivação política" compreendesse torturas, assassinatos e desaparecimentos forçados desconsideraria o $\S 2^{\circ}$ do Art. $1^{\circ}$ da Lei de Anistia, as razões que levaram à elaboração da própria Lei e à jurisprudência do STF.

\section{Ausência de Comunhão de Propósitos}

Além de contestar as justificativas acima, os Contra Militares afastam a possibilidade de que os militares tenham cometido crimes conexos em conformidade com o Art. $1^{\circ}$, caput da Lei de Anistia. Preliminarmente vale ressaltar, como fazem os Contra Militares, que os militares não praticaram crimes políticos nos termos do caput do Art. $1^{\circ}$ da Lei de Anistia, ou seja, crimes que atentassem contra a segurança nacional e a ordem

\footnotetext{
${ }^{96}$ No mesmo sentido, mas de maneira mais radical, escreve o Min. Lewandowski na página 127 da ADPF 153: “(...) os vícios que tisnavam o primeiro diploma legal persistiram integralmente no segundo, ainda que este ostentasse maior hierarquia no ordenamento legal". Os vícios a que se refere o Ministro são as dificuldades de interpretação do conceito de crime político e motivação política. A EC 26/1985 nada esclarece quanto a esse ponto.
} 
política e social. Assim, para serem beneficiados pela anistia seus crimes teriam de ser conexos aos crimes praticados pela oposição armada. No entanto, a Lei de Anistia teria utilizado o conceito de conexão penal material (ou concurso material) previsto no Art. 69 do CP. Os crimes dos militares não possuiriam conexão material com os crimes cometidos pela oposição armada. Assim, os militares não teriam praticado crimes conexos.

As premissas do argumento acima se baseiam em outros dois argumentos. Para justificar a intepretação de que o conceito de conexão da Lei de Anistia é o previsto no Código Penal, os Contra Militares invocam a norma interpretativa que diz que o ordenamento jurídico utiliza seus conceitos de maneira coerente. Assim, deveria ser utilizado o conceito de conexão penal material (ou concurso material) existente no ordenamento, previsto no Art. 69 do CP.

Quanto à aplicação do Art. 69 do CP, os Contra Militares esclarecem que a conexão material entre crimes pressupõe que sejam cometidos pela mesma pessoa ou grupo de pessoas e com comunhão de propósitos ou objetivos. Os militares constituíam grupo de pessoas diferentes e seus crimes não possuíam os mesmos propósitos que aqueles cometidos pela oposição armada. Assim, os crimes dos militares não apresentariam qualquer conexão material, restando justificado o argumento de que os militares não praticaram crimes conexos.

A resposta que os Pró-Militares geralmente oferecem a essa linha de raciocínio é que o sentido de conexão da Lei de Anistia seria especial e mais amplo. Ele permitiria que os crimes praticados pelos militares fossem considerados conexos aos crimes praticados pela oposição armada por conta de sua motivação política, conforme previsto no $\S 1^{\circ}$ do Art. $1^{\circ}$ da Lei de Anistia: "Consideram-se conexos, para efeitos deste artigo, os crimes de qualquer natureza (...) praticados por motivação política” (ADPF 153, Voto Min. Eros Grau, p. 26). Essa interpretação, no entanto, já foi analisada na seção anterior, tendo sido rechaçada do ponto de vista do analista.

Ante todo o exposto sobre o problema da interpretação correta da Lei de Anistia, o analista conclui o seguinte: (i) Não tem sucesso o argumento de que houve conexão dos crimes militares por crimes praticados uns contra os outros; (ii) a motivação política do 
Art. $1^{\circ}, \S 1^{\circ}$ é daqueles que contestaram o regime; (iii) a Lei de Anistia tinha por objetivo excluir crimes violentos do seu âmbito de aplicação; (iv) para saber se um crime político ou conexo foi efetivamente anistiado deve ser analisado sob o duplo critério da preponderância das razões e da atrocidade dos meios; (v) a conexão dos crimes previstos no Art. $1^{\circ}, \S 1^{\circ}$ pressupõe comunhão de propósitos entre aqueles e os crimes políticos.

\section{$\underline{\text { A Anistia dos Militares é Inválida }}$}

O segundo grupo de críticas ao argumento de que os militares foram anistiados diz que a anistia seria inválida. Há duas linhas de justificativa para essa crítica. A primeira baseia-se na jurisprudência da Corte Interamericana de Direitos Humanos, invocada pela própria CIDH ao julgar o Caso Gomes Lund (“Guerrilha do Araguaia”) vs. Brasil. Segundo o entendimento desta corte, autoanistias e anistias de graves violações de direitos humanos violam a Convenção Interamericana de Direitos Humanos no tocante ao dever internacional que o Estado tem de investigar e punir os violadores, bem como aos direitos de proteção judicial das vítimas. Assim, tais anistias seriam inválidas.

A segunda linha de justificativa é a de que os crimes de tortura, assassinato e desaparecimento forçado cometidos pelos agentes da repressão seriam crimes contra a humanidade de acordo com normas obrigatórias (jus cogens) de Direito Internacional dos Direitos Humanos. Assim, seriam insuscetíveis de anistia e imprescritíveis, tornando a Lei de Anistia inválida.

\section{$\underline{\text { Jurisprudência da Corte Interamericana de Direitos Humanos }}$}

Os Contra Militares, a partir da aceitação pelo Brasil da jurisdição da Corte Interamericana de Direitos Humanos (“CIDH”), tentam justificar a invalidade da anistia dos militares a partir da aplicação da jurisprudência desta corte. Assim, é possível construir dois argumentos independentes. 
O primeiro argumento diz que a anistia dos militares do Brasil foi uma autoanistia, considerada inválida pela CIDH. O segundo argumento diz que também não são aceitas pela CIDH as anistias de graves violações de direitos humanos como a que ocorreu no Brasil, mesmo que não seja uma autoanistia (CIDH, Caso Gomes Lund vs. Brasil, § 175).

Aos dois argumentos acima, os Pró Militares opõem a mesma exceção. Segundo eles, a jurisdição da CIDH e, consequentemente, sua jurisprudência não podem ser aplicadas aos fatos do regime militar no Brasil. Conforme o Art. $1^{\circ}$ do Decreto $\mathrm{n}^{\circ}$ 4.463/2002, a jurisdição da CIDH só foi reconhecida pelo Brasil em 8/11/2002, para fatos posteriores a 10/12/1998. Contudo, o regime militar transcorreu de 1964 a 1985 (SWENSSON Jr., 2010, p. 43/44).

Os Contra Militares respondem a essa exceção com outra exceção. A jurisdição da CIDH seria aplicável nos casos de violações de caráter permanente. Não haveria escusa para o Brasil pois, quando do reconhecimento da jurisdição obrigatória da CIDH em 2002, já havia sido julgado o caso Blake vs. Guatemala em 24/01/1998, afastando a restrição temporal para casos de violação permanente. Portanto, em 2002, o Brasil já tinha ciência dessa jurisprudência e não fez qualquer espécie de ressalva (RAMOS, 2004, p. 309/310).

Importante notar que, a princípio, este argumento dos Contra Militares não afasta completamente o argumento de que a jurisdição da CIDH não é aplicável ao regime militar. Justifica-se a aplicabilidade da jurisdição da CIDH apenas nos casos de violação permanente. A discussão, portanto, passa a ser sobre os casos que podem ser considerados de violação permanente.

Ao julgar em 24/11/2010 o Caso Gomes Lund ("Guerrilha do Araguaia”), a CIDH reiterou seu entendimento de que os desaparecimentos forçados constituem violações de caráter permanente que se "iniciam com a privação da liberdade da pessoa e a subsequente falta de informação sobre seu destino, e permanecem até quando não se conheça o paradeiro da pessoa desaparecida e os fatos não tenham sido esclarecidos". ${ }^{97}$

${ }^{97}$ CIDH, Caso Gomes Lund (“Guerrilha do Araguaia”) vs. Brasil, Sentença, 24/11/2010, § 17. 
A falta de investigação das violações, julgamento e estabelecimento de sanções para os responsáveis por graves violações de direitos humanos também são violações permanentes da Convenção Interamericana de Direito Humanos (CIDH, Caso Gomes Lund vs. Brasil, § 18)

Vale notar que a ausência de persecução penal e de punição é uma violação permanente de um dever do Estado. Ou seja, quem comete a violação permanente de não punir e não investigar criminalmente é o Estado. Isso nada tem a ver com a permanência das violações dos militares. Os desaparecimentos forçados são considerados permanentes, mas as torturas e os assassinatos são crimes consumados cuja duração no tempo já se encerrou.

Para que o Estado cumpra seu dever convencional (decorrente da Convenção Americana) de investigar e punir criminalmente, pode ser necessária a revisão legislativa do seu Direito Interno. Aqui fica manifesta a potencial contradição entre o Direito Interno e o Direito Internacional. Pois ainda que a Constituição Federal não permita a revisão legislativa para punir os militares, a violação de Direito Internacional irá permanecer. Como estabelecido no Artigo 27 da Convenção de Viena de Direito dos Tratados, internalizada no Brasil pelo Decreto n ${ }^{\circ} 7.030 / 2009$, um Estado não pode sustentar o descumprimento de um dever internacional com base em disposições do Direito Interno.

Por fim, os Pró Militares podem tentar afastar a proposição de que houve uma autoanistia com base no argumento de que houve um acordo político. Os Contra Militares opõem a esse argumento as mesmas razões apresentadas acima para defender que não houve acordo político. Esse ponto já foi discutido em detalhe anteriormente e não será repetido aqui.

Assim, do ponto de vista do analista, quando o Legislativo reconheceu competência da CIDH, tornou-se aplicável a sua jurisprudência aos casos de desaparecimento forçado, devendo ser reconhecida a invalidade da anistia dos militares ao menos nesse ponto. Além disso, o Brasil está descumprindo seu dever internacional de investigar e punir criminalmente os responsáveis pelas graves violações de direitos humanos, ainda que isso seja lícito do ponto de vista de seu Direito Interno. 
Vale notar, no entanto, que existem fortes críticas ao processo de tomada de decisão da CIDH por defender a investigação e a punição penal sem levar em consideração as particularidades dos contextos de transição política. A afirmação pura e simples de que uma anistia de graves violações de direitos humanos é inválida terminaria por limitar as escolhas e modelos políticos de transição, o que poderia resultar numa decisão pior do ponto de vista dos direitos humanos ${ }^{98}$. Apesar das críticas, a conclusão de que o Brasil está descumprindo seu dever internacional permanece, pois a decisão da CIDH continua vigente e a sua jurisprudência já era essa à época do reconhecimento da jurisdição da Corte.

Por fim, o esforço de reconstrução histórica realizado acima e a construção do Mapa Argumentativo a partir daquele conjunto de fatos lidam com as críticas à falta de atenção ao processo de transição política específico, atentando o máximo possível para as particularidades da experiência brasileira.

\section{Crimes contra a Humanidade}

Segundo os Contra Militares, as torturas, execuções e desaparecimentos forçados cometidos pelos militares seriam crimes contra a humanidade, de acordo com as normas consuetudinárias e obrigatórias (jus cogens) de Direito Internacional. Por isso, seriam insuscetíveis de anistia, a qual deveria ser considerada inválida.

Em resposta, os Pró Militares opõem uma exceção. Para que as normas e institutos de Direito Internacional tenham força vinculante no ordenamento jurídico brasileiro, eles devem antes passar por um processo de internalização (SWENSSON JR., p.41/42). O instituto dos crimes contra a humanidade só viria a ser internalizado junto com o Estatuto

\footnotetext{
${ }^{98}$ As críticas à jurisprudência da CIDH por não atentar às particularidades dos processos de transição políticas dos regimes militares latino-americanos é o objeto da tese de Fábia Fernandes Carvalho Veçoso. Ver especialmente "4.2 As virtudes das anistias", pgs. 123-129. VEÇOSO, Fabia Fernandes Carvalho. Entre absolutismo de direitos humanos e história contextual: aspectos da experiência da Corte Interamericana de Direitos Humanos. Tese (Doutorado em Direito). Faculdade de Direito da Universidade de São Paulo, São Paulo, 2012.
} 
de Roma, que criou o Tribunal Penal Internacional, pelo Decreto 4.388, de 25 de setembro de 2002. Assim, não seriam aplicáveis as regras que definem os crimes contra a humanidade e os atos dos militares não poderiam ser assim considerados.

Contra o argumento acima, os Contra Militares defendem que não há necessidade de internalização das normas internacionais sobre crimes contra a humanidade, pelo fato de se tratar de jus cogens (normas obrigatórias). Com efeito, não faz sentido exigir que a aplicação de uma norma de jus cogens dependa da assinatura de convenções ou tratados. Estes diplomas dependem da vontade do Estado que os assina. A sua obrigatoriedade decorre do pacta sunt servanda, da noção básica de que os acordos devem ser respeitados. A obrigatoriedade do jus cogens, por outro lado, decorre do seu conteúdo e ganha sentido justamente por sua aplicabilidade não depender da vontade do Estado.

Do nosso ponto de vista, esse argumento sobre o jus cogens pode ser avaliado da perspectiva do Direito Internacional e da perspectiva do Direito Interno. Pelo Direito Internacional, mesmo havendo um largo reconhecimento do instituto até mesmo na Convenção de Viena sobre Direito dos Tratados (internalizada pelo Brasil por meio do Decreto $\left.n^{\circ} 7.030 / 2009\right)$, fica a dúvida se o jus cogens poderia estabelecer consequências penais para pessoas físicas, que não sejam sequer membros da comunidade internacional. Já no Direito Interno brasileiro não há clareza sobre o tratamento que deve ser dispensado ao jus cogens internacional.

Seriam necessários maior reflexão e estudo para se descobrir qual deveria ser o tratamento dispensado pelo Direito Brasileiro ao jus cogens ${ }^{99}$. A discussão teria de resolver preliminarmente a seguinte questão: é possível que as normas obrigatórias de direito internacional (jus cogens) determinem um resultado jurídico diferente das normas de direito interno (dualismo), ou não (monismo). Para o caso do dualismo, restaria saber: qual a relação entre os sistemas jurídicos (interno e internacional, principalmente quanto à incorporação de normas); e, ainda, qual deles prevaleceria de fato no final, o que depende da competência de Cortes Internacionais para julgar os fatos do caso (na espécie, a CIDH)

\footnotetext{
${ }^{99}$ De modo geral não há dúvidas sobre a existência do jus cogens, mas muita dúvida quanto à sua definição e implicações precisas para os Estados e o Direito Interno de cada um. Um roteiro de dúvidas quanto ao jus cogens, mostrando as dificuldades do tema, pode ser encontrado em NASSER, Salem Hikmat. Jus Cogens: Ainda esse desconhecido. Revista DIREITO GV nº 2, jul-dez 2005, p. 161/178.
} 
e do modo de exercício da soberania no cumprimento ou descumprimento de eventual decisão pelo Brasil.

Ainda em resposta à necessidade de internalização poderia ser dito que o próprio Poder Legislativo Brasileiro já havia reconhecido o instituto dos crimes contra a humanidade. Isso porque, como relatado acima, o governo militar justificou as exclusões da anistia previstas no Art. $1^{\circ}, \S 2^{\circ}$ da Lei de Anistia com base na ideia de que os opositores do regime teriam praticado "crimes contra a humanidade". Ainda que o conceito de "crimes contra a humanidade" utilizado pelo governo militar não fosse idêntico ao conceito utilizado no Direito Internacional, havendo dúvidas se os crimes excluídos seriam realmente "contra a humanidade", a noção de que existem atrocidades que não podem ser anistiadas estava presente na justificativa legislativa, emprestada do Direito Internacional. Destaque-se que os atos perpetrados pelos militares foram tão ou até mais graves que os atos violentos cometidos pela oposição.

A justificativa legislativa importa, pois a lei é mais do que o seu texto, sendo relevantes também as razões expostas para sua edição. O Legislativo também interpreta o Direito ao desenvolver sua atividade. Se uma norma de Direito Internacional é utilizada como base para um dispositivo legal (Art. $1^{\circ}, \S 2^{\circ}$ da Lei de Anistia), ela pertence ao ordenamento tanto quanto se tivesse sido transcrita, pois está sendo aplicada. Assim, o instituto jurídico dos crimes contra a humanidade teria sido recepcionado pelo Direito Brasileiro, mesmo que não houvesse um dispositivo legal dispondo expressamente sobre eles.

Deve ser comentado que não há certeza quanto à regra interpretativa que dá base a esse argumento. Isso porque não há clareza sobre o que pode ser considerado como internalização de uma norma de Direito Internacional para além da promulgação do texto do tratado ou convenção por meio de Decreto.

Outra exceção oposta pelos Pró Militares para defender a validade da Lei de Anistia é feita com base no Art. $5^{\circ}$, XXXIX da Constituição Federal ${ }^{100}$. Segundo este argumento, não haveria lei anterior a definir o crime, portanto não haveria crime. Mais do que isso, os

100 "XXXIX - não há crime sem lei anterior que o defina, nem pena sem prévia cominação legal" 
Pró Militares argumentam que o Art. 5, XXXIX compreende o princípio nullum crimen, nulla poena sine lege scripta (não há crime, nem pena sem lei escrita) devendo interpretarse o termo "lei" do dispositivo constitucional como referente apenas à lei escrita em sentido estrito, ou seja, as figuras da lei ordinária, lei complementar ou emenda à Constituição. Assim, as normas consuetudinárias não poderiam ser aplicadas ao caso, não podendo o costume internacional ser fonte de direito penal (SWENSSON JR., p.42/43; ADPF 153, p. 190/194, Voto Min. Celso de Mello).

Preliminarmente, cabe anotar sobre esse argumento que, do ponto de vista do Direito Internacional, exigir lei em sentido estrito, quando há jus cogens, é tentar contornar a obrigatoriedade do jus cogens por ele ser costumeiro, o que não pode ser admitido. Do ponto de vista do Direito Interno, exigir lei em sentido estrito é uma interpretação que só se sustenta a depender do tratamento dispensado ao jus cogens pelo Direito Interno. Assim, a interpretação dada pelos Pró Militares ao Art. 5, XXXIX também dependeria dos estudos aprofundados sobre jus cogens mencionados acima. No entanto, para desenvolvimento do diálogo, vamos deixar esses problemas suspensos.

Em resposta a essa exceção os Contra Militares apresentam dois argumentos. O primeiro diz que para fins de normas de Direito Internacional o termo "lei" do Art. $5^{\circ}$, XXXIX da CF/88, fica satisfeito com a existência de um costume. O ordenamento jurídico internacional possui configuração diferente do Direito Nacional, pois não tem o mesmo grau de codificação. No âmbito internacional, o costume é reconhecido como uma fonte de direito tão importante e relevante quanto as convenções internacionais ${ }^{101}$. As fontes do Direito Internacional estão previstas no Art. 38 do Estatuto da Corte Internacional de Justiça da ONU, internalizado pelo Brasil pelo Decreto $\mathrm{n}^{\circ} 19.841$ de 22 de outubro de 1945. A interpretação deste artigo diz que não há hierarquia nem diferenças relevantes entre as fontes para fins de sua aplicabilidade.

O entendimento de que autoanistias e anistias de graves violações de direitos humanos são incompatíveis com o Direito Internacional é bastante amplo. Ao julgar o

\footnotetext{
${ }^{101}$ No mesmo sentido, ver o comentário de Marcos Zilli sobre o voto do juiz argentino Leopoldo Schiffrin na extradição do nazista Schwammberger. ZILLI, Marcos. "O último tango?” in Memória e Verdade: A justiça de transição no Estado Democrático Brasileiro. Coords. SOARES, Inês Virgínia Prado e KISHI, Sandra Akemi Shimada. Belo Horizonte: Fórum, 2009, p. 101/103
} 
Caso Gomes Lund, a CIDH mostra a amplitude desse entendimento, citando o posicionamento da própria CIDH da ONU, com ênfase no Comitê de Direitos Humanos do Tribunal Penal Internacional, da Corte Europeia de Direitos Humanos, da Comissão Africana de Direitos Humanos e dos Povos, da Corte Suprema de Justiça da Nação Argentina, da Corte Suprema de Justiça do Chile, do Tribunal Constitucional do Peru, da Suprema Corte de Justiça do Uruguai e da Corte Constitucional da Colômbia (CIDH, Caso Gomes Lund, §§ 147-170).

Em segundo lugar, o objetivo primordial do Art. 5\%, XXXIX é impedir a arbitrariedade e a opressão do Estado sobre os particulares. Reconhecer apenas a lei escrita em sentido estrito como "lei" no presente caso subverteria essa orientação, pois a consequência seria justamente permitir a arbitrariedade e a opressão do Estado autoritário que agiria sem nenhuma forma de controle. Ao invés de proteger direitos humanos, o dispositivo constitucional colaboraria com a violação de direitos humanos ${ }^{102}$.

Os Pró Militares poderiam responder que seria arbitrário e inseguro para os acusados definir um crime por critérios diferentes dos da lei escrita para os casos de supostas violações de direitos humanos.

Para explicar as respostas dos Contra Militares a essa afirmação, importante realizar alguns esclarecimentos. Como se pode perceber, o problema está na interpretação da expressão "lei anterior que o defina" do Art. 5', XXXIX da Constituição Federal. No fundo, a questão relevante é saber quais as exigências formais que precisamos cumprir para que se possa estabelecer uma consequência penal. No geral, interpreta-se que para um tipo penal como "matar alguém" (CP, Art. 121) ou "subtrair, para si ou para outrem, coisa alheia móvel" (CP, Art. 155) é necessário que exista lei ordinária, complementar ou emenda constitucional.

${ }^{102}$ Novamente, no mesmo sentido ver ZILLI, Marcos, op. Cit., p. 101/103 
No entanto, para dizer que nos casos concretos houve "crimes contra a humanidade" não é necessário um tipo penal. Pois o objetivo não é dizer que os militares cometeram o delito tipificado como "crime contra a humanidade", mas atribuir aos crimes cometidos, de acordo com a legislação vigente à época (lesões corporais, homicídios, seqüestros, etc.), a característica de serem insuscetíveis de anistia, graça ou indulto.

Tendo em vista apenas esse objetivo, os Contra Militares podem defender que não há arbitrariedade nem insegurança, em razão das previsões anteriores fundamentadas no Direito Internacional obrigatório, ainda que o tipo de fonte seja diferente. Ou, ainda, podem arguir que deveria ser levado em consideração o fato de o próprio Art. $1^{\circ}, \S 2^{\circ}$ da Lei de Anistia justificar-se com base no conceito de "crimes contra a humanidade". Os dois casos correspondem às duas respostas ao argumento da internalização e ajudam a harmonizar a interpretação da invalidade da anistia com o Direito Internacional e o Direito Interno.

Por fim, os Pró-Militares poderiam opor um último argumento, dizendo que a ação dos militares não se enquadra na definição que se dá a crimes contra a humanidade, que exige um contexto de ataque generalizado contra a população civil (Art. $7^{\circ}$ do Estatuto de Roma). Os Contra Militares poderiam discutir se a definição do Estatuto de Roma é aplicável ao caso ou se poderia ser usada outra e, ainda, se não seria possível subsumir os fatos à definição do próprio Estatuto de Roma, contrariando frontalmente a afirmativa dos Pró-Militares. Resolver essa dúvida dependeria de discutir mais detalhes sobre os atingidos pela repressão do regime militar.

A nossa conclusão é que nesse estágio de aprofundamento da discussão não se pode afirmar que a anistia dos militares seja inválida do ponto de vista do Direito Interno em virtude da regulação dos crimes contra a humanidade. Como dito, não há clareza sobre o tratamento a ser dispensado ao jus cogens nem conhecimento de suas implicações precisas no Direito Interno. Não há clareza também sobre a possibilidade de se considerar internalizada uma norma ou instituto pelo fato de ter sido utilizada como justificativa para a legislação interna. Além de que, no caso, seria necessário esmiuçar o sentido que o Direito Internacional dá aos crimes contra a humanidade, para verificar o quanto ele se afasta do sentido empregado na justificativa da Lei de Anistia. $O$ debate sobre as 
exigências formais necessárias para se estabelecer uma consequência penal de acordo com o Art. 5 $5^{\circ}$ XXXIX também teria de ser aprofundado. Apesar da proposta dos Contra Militares fazer sentido, as consequências de rever a ideia de que "lei" é lei escrita em sentido estrito teriam de ser melhor avaliadas.

Do ponto de vista do Direito Internacional, também não há clareza sobre a possibilidade do jus cogens estabelecer consequências penais diretas para pessoas físicas. O que também impede uma conclusão pela invalidade da anistia dos militares por essa perspectiva.

\section{Guerra de Fato e de Direito}

Segundo os Pró-Militares, na época do regime militar haveria uma guerra de fato e de direito entre os militares e a oposição armada, a guerra revolucionária. Essa guerra justificaria a interpretação de uma anistia recíproca e afastaria qualquer argumento pela invalidade da anistia dos militares.

A essa tese os Contra Militares opõem vários argumentos. Primeiro, a oposição armada era insignificante e dotada de poderio bélico precário, o que desqualificaria totalmente a ideia de que uma guerra de fato fosse travada no país ${ }^{103}$. Como ilustração, vejam-se os números da Guerrilha do Araguaia. Setenta guerrilheiros contra milhares de combatentes das Forças Armadas.

A ideia de uma guerra de direito, tendo em vista as normas de Direito Internacional, também é difícil de ser sustentada. A oposição armada não era o exército de outro Estado, mas cidadãos revoltados do próprio país. Também não há notícias de qualquer declaração formal do Estado Brasileiro de que estaria em guerra ${ }^{104}$.

\footnotetext{
${ }^{103}$ Nesse sentido, escreve Daniel Aarão Reis “Eram pequenas ações, e minúsculas organizações envolvidas, mas, pelo ineditismo, e pelo simbolismo do desafio, provocavam uma imensa repercussão midiática e na sociedade." (p.3); "De modo que aquela luta desigual acabou em massacre. Encurralados por uma polícia política crescentemente sofisticada e profissional, os grupos e organizações revolucionárias, quase sempre inexperientes e amadores, dispondo apenas da vontade e da ousadia, foram escorraçados da história." (p.4) REIS, 2012, "Repressão e Desenvolvimento", p.3-4.

${ }^{104}$ Em nossas pesquisas não encontramos autores que tratassem de uma guerra propriamente dita a não ser que houvesse pelo menos dois Estados envolvidos. A necessidade de declaração de guerra é objeto de controvérsia doutrinária. Na prática a declaração nem sempre é realizada, pelo risco de ser considerada um ato de agressão em si. No entanto, a sua utilidade para eliminar dúvidas quanto ao estado de guerra e quanto
} 
Os Contra Militares argumentam ainda que mesmo tendo existido uma guerra, não se poderia conceder anistia recíproca. De um lado, porque a oposição armada teria surgido como uma resposta ao endurecimento da repressão do regime militar, como sugerem os dados da pesquisa BNM e como defendia Eduardo Seabra Fagundes. De outro lado, mesmo se tratando de guerra, os militares não teriam seguido normas internacionais sobre o Direito de Guerra, em especial a Convenção de Genebra relativa ao Tratamento dos Prisioneiros de Guerra (1949).

Os Pró-Militares apresentam os seguintes contra argumentos. O endurecimento teria sido uma resposta aos atentados e abusos cometidos pela oposição armada, com destaque para o Atentado do Aeroporto de Guararapes mencionado acima. E, ainda, não seria aplicável a Convenção de Genebra relativa ao Tratamento dos Prisioneiros de Guerra, porque os guerrilheiros, que se enquadrariam como um movimento de resistência organizada (Art. $4^{\circ}, \S 2^{\circ}$ ), não satisfariam os requisitos para receber o tratamento previsto na convenção (previstos no mesmo Art. $4^{\circ}, \S 2^{\circ}$ ), especialmente pelo desrespeito às leis e costumes de guerra nos ataques aos militares ${ }^{105}$.

Os Contra Militares podem apresentar mais dois argumentos. Ressaltar, como concluído acima, que houve atingidos pela repressão que não faziam parte da oposição armada e também que a oposição armada não pode ser vista como um braço armado da esquerda. Assim, não se poderia realizar uma anistia recíproca indiscriminada para todos os militares e todos os excessos cometidos. Ela teria de discernir os participantes da guerra e os excessos praticados contra eles para fazer parte da anistia.

Por último, os Contra Militares podem apontar que o objetivo declarado da Lei de Anistia era não anistiar a oposição armada, tendo sido apenas parte da oposição beneficiada em razão de um defeito de redação. Ou seja, no final das contas a anistia não tinha a intenção de ser recíproca nem teve efeitos recíprocos, beneficiando na prática todos os militares e apenas alguns da oposição armada.

ao seu início preciso é reconhecida. SILVA, Geraldo Eulálio do Nascimento; ACCIOLY, Hildebrando; CASELLA, Paulo Borba. Manual de Direito Internacional Público. 16 ${ }^{\mathrm{a}}$ Ed., revista, atualizada e ampliada. São Paulo: Saraiva, 2008, p. 816/817.

105 Nesse sentido, sem as referências precisas aos artigos da convenção, mas se qualificando os guerrilheiros como terroristas ao invés de combatentes ver USTRA,2012, p.317/318. 
Do nosso ponto de vista, a ideia de uma guerra de fato e de direito não se sustenta perante os dois primeiros argumentos dos Contra Militares, que revelam a insignificância da oposição armada e a falta de formalidade a impedir a caracterização jurídica de uma guerra. Os argumentos sobre quem iniciou a violência e sobre a aplicabilidade da Convenção de Genebra relativa ao Tratamento dos Prisioneiros de Guerra dependeriam da discussão de maiores detalhes fáticos. Por fim, os últimos dois argumentos dos Contra Militares têm sucesso, mostrando que a anistia recíproca teria de ser, no mínimo, limitada.

\section{$\underline{\text { A Emenda Constitucional no } 26 / 1985}$}

Uma das defesas que os Pró-Militares oferecem para a anistia dos militares se baseia em interpretação da EC nº 26/1985. O argumento básico é praticamente idêntico àquele realizado a partir da Lei 6.683/1969:

P1 O Art. $4^{o}, \$ 1^{o}$ da EC $n^{o} 26 / 1985$ diz que os crimes políticos ou conexos são anistiados.

P2 Os crimes praticados pelos militares foram políticos ou conexos.

Cl Os militares foram anistiados.

A argumentação baseada na EC $\mathrm{n}^{\circ}$ 26/1985 oferece algumas vantagens aos militares. Na redação da Emenda não está presente o texto do Art. $1^{\circ}, \S 2^{\circ}$ da Lei de Anistia, o que permitiria o argumento de que a EC n ${ }^{\circ}$ 26/1985 providencia uma espécie de "re-anistia" sem as restrições da anterior. Essa mudança impede ainda o argumento de que haveria uma incoerência interpretativa com base no texto da própria lei, como ocorreu com a Lei de Anistia.

Além disso, a EC nº 26/1985, por convocar a Assembleia Nacional Constituinte, já seria o primeiro ato da nova ordem constitucional que culminaria com a Constituição Federal de 1988. Desse modo, a EC nº 26/1985 teria status constitucional e pertenceria à nova ordem constitucional. Esse argumento impediria os ataques com base na Constituição Federal, anterior ou atual (1988). Afinal, não podem ser opostos ataques ao Poder Constituinte, a não ser que se defenda a possibilidade de "normas constitucionais inconstitucionais". 
Os Contra Militares opõem várias defesas. O primeiro grupo de argumentos trata da interpretação correta da EC no 26/1985. Assim como o Art. $1^{\circ}, \S 2^{\circ}$ da Lei de Anistia não está presente, o Art. $1^{\circ}, \S 1^{\circ}$ que definia como conexos os "crimes de qualquer natureza relacionados com crimes políticos ou praticados por motivação política" também não está. Desse modo, a natureza política ou conexa dos crimes dos militares não poderia ser baseada na motivação política. Eles não seriam crimes políticos, pois não atentavam contra a ordem política nem contra as leis de Segurança Nacional. Também não se poderia dizer que fossem conexos, pois não possuíam comunhão de propósitos com os crimes políticos.

Ainda que fosse possível sustentar que os crimes praticados pelos militares eram políticos, a jurisprudência do STF continua sendo aplicável para verificar os casos concretos pelos critérios de preponderância da intenção e de atrocidade dos meios. Mais uma vez, os excessos não se encaixariam nesses critérios, ou teriam de ser verificados caso a caso.

Importante apontar que quanto à EC n²6/1985 não se fala em uma renovação do suposto acordo político da anistia recíproca. Mas, mesmo que se falasse, os argumentos que apontam a sua total falta de verossimilhança permaneceriam válidos.

Ao final, neste grupo de alegações, vale apontar que, como relatado, a questão penal não foi parte do debate legislativo que circundou a $E C \mathrm{n}^{\circ}$ 26/1985. O problema na época, que levou a "enxertar" o Artigo $4^{\circ}$ no ato convocatório e que, inclusive, tomou as manchetes dos jornais era o da anistia para militares punidos com base em atos administrativos e o das promoções para fins de cálculo da aposentadoria (Art. $4^{\circ}, \S 3^{\circ}$ da EC no 26/1985 contra o Art. $4^{\text {a }}$ da Lei de Anistia). Esse contexto permite apontar para uma Emenda Constitucional que se limitava a reproduzir o essencial da Lei de Anistia de 1979, com pequenas alterações. De maneira nenhuma buscava mudar a parte criminal.

De outro lado, os Contra Militares atacam as ideias de que a EC nº 26/1985 teria o mesmo status que as normas da Constituição Federal de 1988 e que permaneceria como parte da nova ordem constitucional. Mesmo considerando que a Emenda que convocou a Constituinte fosse parte da nova ordem, não se poderia atribuir a ela o status da 
Constituição Federal de 1988. Isso porque a legitimidade de um ato convocatório é diferente e inferior à legitimidade da própria Assembleia Constituinte e do resultado de todos os debates realizados pela Assembleia. Além da diferente composição, temos no mínimo de valorizar o processo de debate e reflexão que originou a Constituição Federal de 1988. Como destaca ainda o Ministro Ayres Britto (ADPF 153, p. 145/146), a Assembleia Constituinte não está presa ao ato de convocação originário.

Ao analisar o texto da Constituição Federal de 1988, observamos que apesar do Artigo $8^{\circ}$ da $\mathrm{ADCT}$ tratar da anistia, não há qualquer referência à anistia de crimes políticos ou conexos. Observamos ainda que existem dispositivos como o Artigo $5^{\circ}$, XLIII, que declara insuscetíveis de graça ou anistia os crimes de tortura e terrorismo, e o Artigo $5^{\circ}$, XLIV, que declara inafiançáveis e imprescritíveis a ação de grupos armados, civis ou militares, contra a ordem constitucional e o Estado Democrático de Direito. Tendo em vista esses elementos, os Contra Militares concluem que a Constituição Federal não ratificou a anistia que seria concedida pela $E C n^{\circ}$ 26/1985. A manifestação final do Poder Constituinte Originário sobrepõe-se à sua manifestação inicial aparentemente em sentido contrário. Assim, deve ser considerado que a EC nº 26/1985 nunca gerou efeitos na anistia. No mesmo sentido, de que não houve ratificação, vejam-se os votos do Min. Lewandowski (ADPF 153, p. 127) e da Min. Carmen Lúcia (ADPF 153, p.84/85).

O último argumento que os Contra Militares poderiam apresentar em relação ao tema da revisão constitucional da anistia seria construído a partir da aplicação dos novos dispositivos da Constituição Federal de 1988 (Artigo $8^{\circ}$ ADCT, Artigo 5º XLIII e XLIV) para considerar revogada tacitamente a anistia dos militares (se ela existiu). A esse argumento os Pró-Militares podem responder que, segundo a jurisprudência do STF, as disposições de uma nova ordem constitucional só operam ex nunc (daquele momento para frente), a não ser que digam expressamente o contrário. Assim, as disposições da CF/88 não poderiam retroagir para eliminar os efeitos da Lei de Anistia (ADPF 153, p. 195/196, Voto Min. Celso de Mello). 
Em nossas pesquisas não encontramos argumentos capazes de responder às objeções dos Contra Militares segundo as quais a EC 26/1985 não beneficiaria os militares e teria sido suplantada pela $\mathrm{CF} / 88$. No entanto, pelo debate acima também não seria possível interpretar a $\mathrm{CF} / 88$ de modo a dizer que ela retroativamente revogasse a anistia, em virtude da objeção oferecida pelo Min. Celso de Mello.

\section{Retroatividade (I.1.A.2)}

Ainda que se considere que não foi concedida anistia aos militares (correta interpretação da Lei de Anistia) ou que foi inválida (invalidade da anistia dos militares), para que haja persecução penal é necessário enfrentar o argumento baseado na irretroatividade da lei penal (Art. 5 $, \mathrm{XL}, \mathrm{CF}$ ). Segundo os Pró Militares, como a Lei de Anistia descriminalizou os atos dos militares, desfazer seus efeitos implicaria criminalizar seus atos retroativamente, de maneira encoberta (SWENSSON JR., p. 40; ADPF 153, p. 186/189, Voto Celso de Mello).

Os Contra Militares chamam a atenção para que no caso de crimes permanentes, cuja continuidade delitiva perdurou após a edição de Lei de Anistia, não há retroatividade, pois o crime continuou a atualizar-se após a Lei de Anistia já ter esgotado seus efeitos. Em alguns casos, a permanência do crime se estende até hoje. É o que ocorre, por exemplo, com os desaparecimentos forçados da Guerrilha do Araguaia, julgados pela CIDH (CIDH, Caso Gomes Lund v. Brasil, § 179).

Além disso, os Contra Militares podem argumentar que a Lei de Anistia nunca teve o efeito de descriminalizar os atos dos militares. Essa será a consequência caso se aceite o argumento da interpretação correta da Lei de Anistia. Também não haverá efeitos caso se aceite o argumento de que a anistia dos militares foi inválida (nula) e que os atos inválidos (nulos) não geram efeitos jurídicos. Ou seja, para os Contra Militares, uma vez aceitos os argumentos que afastam a anistia, também não cabe falar em retroatividade. 
Isso não significa negar que de fato houve interpretações em sentido contrário e que o Estado, inclusive o Poder Judiciário, por muitos anos interpretou que os militares tinham sido anistiados. No entanto, ainda que tudo isso tenha ocorrido de fato, de direito todas essas decisões e interpretações estariam erradas, não se podendo atribuir-lhes efeitos jurídicos.

Os Pró-Militares podem contra argumentar que a segurança jurídica é um valor relevante que protege também as situações de fato, especialmente aquelas que tiveram o aval do Estado e do Poder Judiciário. Não se poderia negar que, de fato, a Lei de Anistia teve o efeito prático de impedir a punição dos militares. O instituto da irretroatividade protegeria então estes efeitos práticos da Lei de Anistia, impedindo a perseguição penal dos militares (SWENSSON JR., p.40).

Por sua vez, os Contra Militares podem apresentar resposta a esse argumento. Preliminarmente, não faz sentido que todo e qualquer efeito prático receba proteção jurídica da segurança jurídica. Caso assim fosse, o Direito perderia a sua capacidade de corrigir fatos do passado. Assim, existem meios específicos para se proteger a segurança jurídica, consubstanciados em alguns institutos e critérios para sua aplicação.

A irretroatividade das leis serve para impedir que uma nova lei perturbe uma situação que era juridicamente correta no passado e não simplesmente uma situação juridicamente aceita por equívoco. Mesmo a coisa julgada, o resultado final de processos judiciais, pode ser desfeita em algumas situações (ação rescisória, Art. 485 e seguintes do CPC; revisão criminal, Art. 621 e seguintes do CPP), sendo a rescisão da coisa julgada considerada a correção de um erro, não havendo problemas de retroatividade.

A proteção que a segurança jurídica confere às situações de conflito com a lei (atos inválidos) se dá por meio do instituto da prescrição e não da irretroatividade. A prescrição determina o lapso de tempo a partir do qual uma pretensão jurídica contra uma situação de conflito com a lei não pode mais ser satisfeita, garantindo a proteção de situações de fato. O critério para sua utilização é o prazo prescricional. Há prazo para o exercício do direito de punir alguém e por vezes até para rescindir a coisa julgada (por exemplo, o prazo de 
dois anos da ação rescisória, previsto no Art. 495 do CPC). Assim, o instituto da irretroatividade não protege os efeitos práticos da Lei de Anistia, posto que inválidos.

Do ponto de vista do analista, os argumentos dos Contra Militares alcançam sucesso, afastando a ideia de que a irretroatividade protegeria os militares neste caso.

\section{$\underline{\text { ADPF } 153 \text { - Decisão do STF }}$}

Feitas as discussões sobre anistia e irretroatividade é possível comentar a decisão do STF, em especial a linha de argumentação do Ministro Relator Eros Grau. O seu voto pode ser resumido da seguinte forma. A intenção do legislador da Lei 6.683/1979 foi estender a anistia às atrocidades cometidas pelos agentes do Estado em virtude do acordo político estabelecido à época (ADPF 153, p.24/28, Voto Min. Eros Grau). Assim, não haveria dúvidas de que a Lei de Anistia tinha o efeito de anistiar os militares.

Na sequência, o Min. Eros Grau argumenta que as anistias são leis-medida (ADPF 153, p.30/37, Voto Min. Eros Grau), que tem seus efeitos esgotados logo após a sua entrada em vigor. Assim, caso o STF revisse a Lei de Anistia agora, ele estaria reescrevendo a lei, o que não é de sua competência. O único Poder competente para rever a Lei de Anistia seria o Legislativo (ADPF 153, p. 38/42, Voto Min. Eros Grau).

As discussões realizadas acima, tanto sobre a correta interpretação da Lei de Anistia, quanto sobre a sua validade, enfrentam a primeira parte da argumentação do Min. Eros Grau. Como exposto, quanto ao problema da interpretação correta, a ideia de que houve um acordo político não parece se sustentar e, de outro lado, há uma interpretação concorrente pela não inclusão dos militares que harmoniza elementos diversos do ordenamento jurídico e as razões expostas no processo legislativo.

Ainda que houvesse acordo político a sustentar que a vontade do legislador seria beneficiar os militares, permaneceria a necessidade de justificar a preferência por essa intenção do "legislador real" à intenção do "legislador racional" ${ }^{106}$, que harmoniza as

\footnotetext{
${ }^{106}$ A noção do legislador racional tem a ver com a construção de um conjunto de regras para a interpretação que pressupõe, por exemplo, a coerência entre as normas ditadas por ele. Utilizamos a noção aqui para enfatizar a coerência com o restante do ordenamento que a interpretação traz. Sobre a figura do legislador
} 
razões expostas no processo legislativo com o texto de lei e o entendimento do STF. No mínimo, o "legislador real" estaria sendo incoerente com as razões que ofereceu na elaboração da Lei de Anistia. Se a interpretação jurídica tem de eliminar contradições e incoerências, a interpretação a partir do acordo político não poderia se sustentar.

Assim, aceito o argumento da interpretação correta da Lei de Anistia, o provimento judicial do STF não terá mais de desfazer os efeitos (constitutivo negativo) de uma leimedida do Poder Legislativo, mas apenas de declarar que eles nunca ocorreram, o que afasta também alegações de retroatividade. Declarar a interpretação correta do Direito é função do Poder Judiciário.

\section{Prescrição (I.1.A.3)}

Após a anistia e a retroatividade, a terceira objeção contundente à perseguição penal dos militares é a da prescrição. Segundo esse argumento, ainda que não houvesse anistia e retroatividade, nos dias de hoje já teria sido extinta a pretensão (no sentido técnico jurídico) de punir os responsáveis pelos eventos do regime militar.

\section{Argumento A (Prescrição dos crimes)}

P1 Os crimes dos militares ocorreram até 1979.

P2 O CP estabelece como marco inicial para a prescrição o dia em que o crime se consumou (Art. 111, I).

P3 O CP estabelece como prazo máximo para prescrição 20 anos (Art. 109, I).

C1 Os crimes dos militares prescreveram (até 1999).

Para superar o óbice da prescrição os Contra Militares apresentam duas objeções. A primeira diz que parte dos crimes cometidos, notadamente os desaparecimentos forçados, possuem caráter permanente e ainda não estariam prescritos. A segunda defende que por se tratar de crimes contra a humanidade eles seriam imprescritíveis. Às duas objeções

racional e suas origens nas tentativas de construir uma Ciência do Direito no século XIX, ver FERRAZ JÚNIOR, Tércio Sampaio. A Hipótese do Legislador Racional e a Noção de Justiça. Cadernos de Direito GV, v. 6, p. 21-41, 2009. 
somaremos uma terceira, segundo a qual a prescrição só começaria a correr a partir do momento em que surgisse a possibilidade de ajuizar-se uma ação penal contra os militares, conforme o princípio da actio nata.

\section{Desaparecimentos Forçados e Crimes Permanentes}

Antes de apresentar a discussão, cabem alguns esclarecimentos. O desaparecimento forçado consiste na privação de liberdade de um indivíduo, geralmente seguido da sua execução e ocultação dos seus restos mortais. Foi um método bastante utilizado pelos regimes militares latino-americanos para eliminar seus opositores. $O$ nome "desaparecimento forçado" vem do fato de que o aparato militar costumava negar qualquer informação sobre o indivíduo, inclusive a sua captura, tratando-o não como um prisioneiro, mas como um desaparecido. No cárcere, desaparecidos não têm quaisquer direitos, pois oficialmente não estão lá. Além disso, desaparecidos não entram nas estatísticas de mortos, e não é necessário correr o risco de inventar versões oficiais para esconder assassinatos.

Os desaparecimentos forçados ${ }^{107}$ foram objeto da Convenção Interamericana sobre o Desaparecimento Forçado de Pessoas, assinada em 09 de junho de 1994 em Belém do Pará. O texto desta convenção foi aprovado pelo Congresso Nacional por meio do Decreto Legislativo $n^{\circ} 127 / 2011$ e está aguardando a ratificação pelo Poder Executivo por meio de Decreto. O tema também foi objeto da Convenção Internacional para a Proteção de todas as Pessoas contra o Desaparecimento Forçado, adotada no âmbito da ONU, em Nova Iorque na data de 20 de dezembro de 2006.

O Artigo $2^{\circ}$ da Convenção Interamericana, que define o desaparecimento forçado, ajuda a esclarecer em que consiste o delito:

"Para os efeitos desta Convenção, entende-se por desaparecimento forçado a privação de liberdade de uma pessoa ou mais pessoas, seja de que forma for, praticada por agentes do Estado ou por

\footnotetext{
${ }^{107}$ Para um histórico mais completo e detalhado dos diplomas normativos internacionais acerca do tema, desde a Resolução 33/173 da ONU (1978), ver PERRUSO, Camila Akemi. O Desaparecimento Forçado de Pessoas no Sistema Interamericano de Direitos Humanos - Direitos Humanos e Memória. 2010. Dissertação (Mestrado em Direito), Faculdade de Direito da Universidade de São Paulo, São Paulo, p. 23-38
} 
pessoas ou grupos de pessoas que atuem com autorização, apoio ou consentimento do Estado, seguida de falta de informação ou da recusa a reconhecer a privação de liberdade ou a informar sobre o paradeiro da pessoa, impedindo assim o exercício dos recursos legais e das garantias processuais pertinentes."

A definição da Convenção Interamericana não pressupõe necessariamente a execução do desaparecido. No entanto, a possibilidade de morte é reconhecida, sendo o delito considerado de caráter contínuo ou permanente "enquanto não se estabelecer o destino ou paradeiro da vítima" (Artigo $3^{\circ}$ ). Isso inclui a descoberta e identificação dos restos mortais da vítima.

O disposto na Convenção Interamericana se harmoniza com o entendimento da Corte Interamericana de Direitos Humanos ${ }^{108}$, estabelecido a partir do caso Blake vs. Guatemala, julgado (mérito) em 24 de janeiro de 1998. A posição da Corte sobre o caráter contínuo ou permanente do delito foi reiterada por ocasião do julgamento de Gomes Lund vs. Brasil (“Guerrilha do Araguaia”), em 2010 (§ 179).

Sem a internalização da Convenção Interamericana sobre o Desaparecimento Forçado de Pessoas, o Brasil ainda não possui em seu ordenamento a tipificação do crime de desaparecimento forçado, o que traz dificuldades adicionais para a caracterização da conduta. O desaparecimento forçado seria composto sempre pelo crime de sequestro (Artigo 148, CP) e, geralmente, pelos crimes de homicídio (Artigo 121, CP) e ocultação de cadáver (Artigo 211, CP).

Conforme o Código Penal (Artigo 119), mesmo havendo crime continuado (Artigo $71, \mathrm{CP})$ o prazo prescricional deve ser contado isoladamente para cada crime, a partir da sua consumação. Os crimes de sequestro e ocultação de cadáver são considerados crimes permanentes (CP, Art. 111, III), perdurando o primeiro até o término do sequestro e o último até que se encontre o cadáver. De outro lado, o homicídio é crime instantâneo, consumando-se com a morte da vítima.

\footnotetext{
${ }^{108}$ Para uma lista e breve histórico de casos de desaparecimento forçado julgados pela Corte Interamericana de Direitos Humanos até 2010 ver PERRUSO, Claudia Akemi, 2010, p. 99-124
} 
Os crimes se sucedem no tempo na seguinte ordem: sequestro, homicídio e ocultação de cadáver. Para a contagem correta do prazo prescricional seria necessário, portanto, identificar com precisão quando o sequestro terminou, por meio do homicídio. $\mathrm{O}$ problema com os desaparecimentos forçados reside justamente neste ponto. Na Guerrilha do Araguaia e em grande parte dos casos os corpos sequer foram encontrados, não havendo informação precisa sobre datas. A discussão é sobre qual o critério e a partir de que momento o desaparecido pode ser legalmente presumido morto para fins de contagem do prazo prescricional penal dos crimes de sequestro e homicídio.

Feitos os esclarecimentos acima, podemos passar à discussão em si. Contra o argumento de que houve prescrição, os Contra Militares podem opor a permanência dos crimes de ocultação de cadáver e sequestro.

Para os casos de ocultação de cadáver o prazo prescricional só começará a correr a partir do momento em que encontrados os restos mortais da vítima. Vale apontar que existem discussões sobre ter havido ou não ocultação de cadáver nos casos de ossadas de guerrilheiros encontradas em valas comuns. Como mencionado no relato dos fatos, o Coronel Ustra defende que foram seguidos os procedimentos legais para o enterro dos restos mortais, existindo dificuldades em identificar as vítimas, pois usavam nomes e documentos falsos. Além disso, teriam sido feitos os melhores esforços para descobrir-se a verdadeira identidade das vítimas (USTRA, 2012, p.471/478). Para os casos de restos mortais da Guerrilha do Araguaia não se encontra esse tipo de defesa pelos Pró-Militares.

Para os casos de sequestro o mencionado problema da presunção de morte se coloca. Os Pró-Militares opõem dois argumentos para dizer que a permanência cessou com a morte da vítima de sequestro. De um lado, argumenta-se que Artigo $1^{\circ}$ da Lei 9.140/1995 determinou que os desaparecidos estão legalmente mortos, o que faria cessar a permanência:

“Art. $1^{o}$ São reconhecidos como mortas, para todos os efeitos legais, as pessoas que tenham participado, ou tenham sido acusadas de participação, em atividades políticas, no período de 2 de setembro 
de 1961 a 5 de outubro de 1988, e que, por este motivo, tenham sido detidas por agentes públicos, achando-se, deste então, desaparecidas, sem que delas haja notícias. (Redação dada pela Lei $n^{o} 10.536$, de 2002)"

De outro lado, defende-se que, ao analisar as provas, os juízes devem aplicar as regras da experiência comum (conforme o Artigo 335 do CPC, de aplicação subsidiária ao processo penal). Nos casos concretos, costuma-se observar que faz muito tempo que se obteve a última notícia da vítima (década de 1970), que as vítimas teriam idade muito elevada nos dias de hoje, e que, por vezes, há relatos ou indícios de que as vítimas teriam sido executadas ou morrido em tortura. Ou seja, todos os fatos levam a crer que as vítimas já estejam mortas, podendo ser realizada presunção simples ${ }^{109}$ nesse sentido.

Cada uma dessas exceções é atacada por vários argumentos dos Contra Militares. Contra a tese de que o Artigo $1^{\circ}$ da Lei 9140/1995 teria estabelecido uma presunção legal de morte, aponta-se que objetivo da referida Lei era apenas facilitar a sucessão e a indenização dos familiares dos desaparecidos políticos. Eventuais consequências penais da presunção de morte (como a interrupção da permanência) sequer fizeram parte do debate que antecedeu a elaboração da lei ${ }^{110}$. Nem poderiam, afinal os debates políticos partiam da premissa de que não se poderiam ultrapassar os limites supostamente estabelecidos pela Lei da Anistia, que envolveriam a impossibilidade de responsabilização dos militares. Por isso, o dispositivo não geraria efeitos para fins penais.

Em resposta, os Pró-Militares ressaltam que o texto do Artigo $1^{\circ}$ da Lei 9.140/95 é expresso ao dizer "todos os efeitos legais", sem quaisquer exceções. Os Contra Militares, de sua parte, poderiam objetar que a intepretação literal da lei desacompanhada de qualquer fundamentação ou justificativa (nem nos debates legislativos, nem construída posteriormente) não subsiste perante a interpretação contextual oferecida, que leva em consideração os objetivos da lei e as circunstâncias de sua elaboração.

\footnotetext{
${ }^{109}$ As presunções podem ser "legais", quando determinadas por uma norma jurídica ou "simples", quando construídas a partir dos fatos e da experiência comum ou técnica.

${ }^{110}$ Para um relato das pressões nacionais e internacionais que levaram à edição da Lei 9.140/1995, também conhecida como Lei dos Desaparecidos, bem como dos debates sobre a sua elaboração, ver MEZAROBBA, Glenda, op. Cit, 2006, Capítulo 2 - A Lei dos Desaparecidos, p. 65-113. O relato confirma a premissa utilizada pelos Contra Militares.
} 
Não obstante, de modo subsidiário, os Contra Militares apresentam outros argumentos. Ainda que a Lei 9.140/1995 determinasse a presunção legal de morte para fins penais, restaria saber qual seria a data para início da contagem do prazo prescricional. $\mathrm{O}$ texto do Artigo $1^{\circ}$ realiza uma declaração de que os desaparecidos são reconhecidos como mortos, sem estabelecer data, e o Artigo 16 afirma que a lei entra em vigor na data de sua publicação, que ocorreu em 5 de dezembro de 1995. Assim, a data presumida da morte, e da cessação da permanência do crime de sequestro, seria o próprio dia 05 de dezembro de 1995. O reconhecimento desta data traz algumas consequências.

Em 05 de dezembro de 1995 estava vigente o Artigo 5º XLIV da Constituição Federal segundo o qual "constitui crime inafiançável e imprescritível a ação de grupos armados, civis ou militares, contra a ordem constitucional e o Estado Democrático". Sendo os desaparecimentos forçados fruto da ação de grupos militares armados que buscavam eliminar a oposição política (violando o Estado Democrático) por meio da violação de direitos humanos fundamentais (violando a ordem constitucional), as condutas seriam imprescritíveis nos termos do Artigo $5^{\circ}, \mathrm{XLIV}^{111}$.

É claro que os Pró-Militares podem alegar que a ação dos militares não se enquadraria nesse artigo, pois eles não estariam agindo contra a ordem constitucional nem contra o Estado Democrático. Ao contrário, estariam agindo para proteger a ordem constitucional e o Estado Democrático da ameaça comunista. Para fins deste mapa, não entraremos em maiores detalhes sobre a discussão da interpretação do Art. $5^{\circ}$, XLIV da $\mathrm{CF} / 88$ e subsunção das ações dos militares à norma que ele estabelece.

Os Pró Militares poderiam argumentar ainda, que, para fins do crime de sequestro, a aplicação do Art. $5^{\circ}$, XLIV da CF/88 seria vedada, por se tratar de aplicação de lei penal (sobre prescrição, questão de direito material) posterior mais grave ao fato que constituiria

\footnotetext{
${ }^{111}$ Vale apontar que até a entrada em vigor da Constituição Federal de 1988 estava em vigor a Constituição Federal de 1967, com a redação que lhe foi dada pela Emenda Constitucional no 01/1969. Essa constituição anterior previa em seu Art. 152, que a organização e funcionamento dos partidos políticos deveriam respeitar, dentre outros, os princípios do "regime representativo e democrático, baseado na pluralidade de partidos e na garantia dos direitos fundamentais do homem". Com as Emendas Constitucionais n $\mathrm{n}^{\circ}$ 11/1978 e n $\mathrm{n}^{\circ}$ 25/1985 o texto sofreu pequenas alterações, mas os princípios foram mantidos. Os Arts. 153 e 154 disciplinavam os direitos e garantias individuais, fazendo o papel de nosso atual Artigo $5^{\circ}$.
} 
o crime. No entanto, segundo a Súmula $\mathrm{n}^{\circ} 711$ do STF "A lei penal mais grave aplica-se ao crime continuado ou ao crime permanente, se a sua vigência é anterior à cessação da continuidade ou da permanência". Assim, não haveria óbice à aplicação do Artigo $5^{\circ}$, XLIV.

Importante observar que se não fosse o caso da imprescritibilidade prevista no Artigo $5^{\circ}$, XLIV da CF/88, a punibilidade do crime de sequestro estaria prescrita em 2007, pelo transcurso do prazo de doze anos (Art. 109, III, CP) previsto para a pena máxima de oito anos de sequestro qualificado (Art. 148, $\S 2^{\circ}$ ).

Mas assumir a data da publicação da Lei 9.140/1995 como data da morte pode trazer outras consequências penais além da interrupção da permanência do crime de sequestro e pode gerar ainda mais debates. Mesmo que presumir a morte não signifique presumir o homicídio, havendo provas suficientes, um juiz pode concluir no caso concreto que o desaparecido capturado tenha sido executado. Assim, poderia o juiz assumir a data da publicação da Lei 9.140/1995 como data da morte para fins de caracterização de homicídio e interrupção da permanência do crime de sequestro? Anote-se que, caso a resposta seja positiva, o homicídio teria ocorrido em 1995 e a sua prescrição só se daria em 2015, após o transcurso do prazo de 20 anos (Art. 109, I, CP).

Os Pró-Militares podem defender que não, afinal, se o homicídio já tivesse ocorrido antes da data de publicação, a nova data postergaria o início do prazo prescricional, prejudicando o réu. Deveria assim ser realizada investigação probatória e pronunciamento judicial sobre a data provável de falecimento.

Esse argumento dos Pró-Militares pode soar contraditório em relação à afirmação de que a Lei 9.140/1995 presumia a morte da vítima. Assim, alguns esclarecimentos são importantes. Uma coisa é presumir a morte, outra coisa é presumir que a morte ocorreu em determinada data. Com a presunção de que houve a morte, o ônus de provar o contrário (se for admitida prova nesse sentido) passa a ser dos Contra Militares. A dúvida restante é somente quanto à data, que seria estabelecida em algum momento entre a captura e 05 de dezembro de 1995. O que os Pró-Militares defendem é que não se pode assumir 05 de dezembro de 1995 como data da morte, sob o risco de se prejudicar os réus na contagem do 
lapso prescricional (tanto no caso de sequestro, quanto no caso de homicídio, com efeitos maiores nesse último caso).

Do nosso ponto de vista, o argumento dos Pró-Militares é pertinente e deveria ser realizada investigação probatória sobre a data provável do falecimento. Vale lembrar que, se a data provável for estabelecida entre a promulgação da $\mathrm{CF} / 88$ e 05 de dezembro de 1995, terá de ser enfrentado o argumento da imprescritibilidade com base no Art. 5 , XLIV da $\mathrm{CF} / 88$.

Como última resposta à presunção de morte prevista na Lei 9.140/1995, os Contra Militares poderiam arguir que a presunção estabelecida pela Lei 9.140/95 é relativa, isto é, admite prova em contrário. Destarte, ela poderia ser derrubada, se no caso concreto fossem trazidos indícios ou provas de que a vítima do sequestro ainda estivesse viva ou tivesse morrido em momento diferente e posterior à publicação da Lei 9.140/95. Entretanto, é pouquíssimo provável que nos casos concretos os Contra Militares encontrem qualquer prova nesse sentido, visto que a prática era esconder informações e executar os desaparecidos.

Ainda que afastada a aplicação da Lei 9.140/95 para determinar a presunção legal de morte das vítimas de desaparecimento, os Pró-Militares podem basear-se em presunção simples, mostrando que os indícios apontam fortemente para o seu falecimento.

Em contrário, argumenta-se que não se pode realizar presunção simples no caso, devendo haver exame de corpo delito (Art. 158, CPP), pois a infração deixa vestígios (o corpo da vítima), ou sentença cível determinando a data provável do falecimento, pela extrema probabilidade de morte da vítima (Art. $7^{\circ}$, I, CC). Não se poderia afastar a necessidade desses requisitos, pois o exame do corpo delito só se torna dispensável quando desaparecidos os vestígios (Art. 167, CPP), e a sentença cível só poderia ser dada depois de esgotadas as buscas e averiguações (Art. $7^{\circ}$, parágrafo único, CC). Nos casos concretos, não há elementos que permitam a conclusão de que os vestígios tenham desaparecido, apenas de que foram ocultos, e as buscas por corpos da Guerrilha do Araguaia permanecem, como relatado acima. 
Em qualquer dos casos, seja exame de corpo delito, seja sentença determinando a data provável do falecimento, o objetivo das normas jurídicas é garantir que sejam realizados todos os esforços para se encontrar a pessoa ou os seus restos mortais antes de se optar pelo caminho da presunção, que só deve ser utilizado em último caso, quando desaparecidos os vestígios ou esgotadas as buscas e averiguações. Busca-se, assim, evitar um erro de fato grave, que geraria inúmeras consequências cíveis e penais. Por isso, mesmo soando a possibilidade de vida da vítima muito distante da realidade, não se pode presumir a morte antes de um procedimento probatório cuidadoso. Além disso, mesmo que se encontrem apenas restos mortais, eles podem ajudar a determinar a data da morte com maior precisão, sendo que a data também é extremamente importante, visto a contagem do prazo prescricional de eventuais crimes.

De outro lado, os Pró-Militares podem advertir que se tomem alguns cuidados com esse argumento. Primeiro, a exigência do exame de corpo delito não pode se converter em uma busca eterna por restos mortais. Mesmo que não se tenha elementos para defender que os vestígios tenham desaparecido, em algum momento a busca tem de ser concluída, e assumido que não há o que encontrar. Trata-se de um argumento pelo desconhecimento (argument from ignorance) baseado em uma suposição de mundo fechado (closed world assumption), em que se obteve conhecimento de algo dentro de um âmbito determinado: se não há mais onde procurar, deve ser concluído que o elemento procurado não existe (FCA, $318 / 326)$.

Segundo, a exigência que se faz, seja pelo processo penal, seja pelo processo civil é, no fundo, a de um procedimento probatório cuidadoso para averiguar a situação antes de realizar uma presunção. Não faz sentido exigir que exista necessariamente uma sentença do juízo cível nos termos do Artigo $7^{\circ}$ do Código Civil, para que haja morte presumida. No caso concreto, os militares réus em eventual ação penal teriam interesse na presunção de morte das vítimas. Contudo, enfrentariam sérias dificuldades processuais para propor ação cível em que a pessoa fosse declarada presumidamente morta, pois no juízo cível o interesse dos autores é sucessório e patrimonial, decorrendo desse fato a sua legitimidade processual. Não existe nenhuma vantagem do juízo cível em relação ao juízo penal em termos de capacidade probatória. Em complemento, o juízo penal guia-se pela busca da 
verdade material em detrimento da verdade formal, suscitando um esforço probatório mais intenso.

Terceiro, em eventual ação penal proposta contra réus militares pelo crime de sequestro, o ônus da prova de que houve privação da liberdade seria da acusação, mas o ônus da prova de que cessou a permanência por meio da morte da vítima, seria da defesa, por ser uma exceção (Art. 333, II, CPC) que busca desclassificar o crime cometido para homicídio (concomitantemente deslocando a competência para o Tribunal do Júri). Como a defesa não pode se basear em presunção simples, pois o crime de homicídio deixa vestígios, teria de lhe ser dada a oportunidade de provar que a vítima já havia morrido há muito tempo, sob pena de cerceamento do direito de defesa. Assim, não poderia haver condenação antes da conclusão do procedimento probatório relativo ao homicídio.

A nossa posição de analista relativa a cada crime é a seguinte. Quanto ao crime de ocultação de cadáver, deve ser avaliado concretamente se houve intenção de ocultar, observando-se as alegações do Coronel Ustra. Destaca-se que no caso da Guerrilha do Araguaia não parece haver dúvida, e o crime permaneceria.

Quanto aos crimes de sequestro e homicídio, não se aplicaria a presunção de morte prevista na Lei 9.140/1995, que se baseia em interpretação puramente literal da lei, desprezando seus objetivos e o processo de sua elaboração. Não houve argumentos a justificar a preferência pela interpretação literal da lei. Preferível, portanto, a interpretação que melhor atende aos seus objetivos (lembrando-se que argumento pelo objetivo da lei é um argumento de justificação, como exposto no Capítulo 2). Assim, deveriam ser realizados os procedimentos investigatórios, ainda que no próprio processo criminal, para fixação da data provável da morte e de eventual homicídio e, a partir daí, realizar-se a contagem do prazo prescricional para o sequestro e para o homicídio. A depender da data, o argumento da imprescritibilidade (Art. $5^{\circ}$, XLIV da CF/88) teria de ser analisado em maiores detalhes. 


\section{$\underline{\text { Imprescritibilidade }}$}

Os Contra Militares oferecem dois argumentos para defender a imprescritibilidade dos crimes cometidos pelos militares. O primeiro argumento baseia-se também no jus cogens de Direito Internacional e afirma que os crimes contra a humanidade são imprescritíveis. A forma do debate é a mesma exposta naquela seção, podendo ser aproveitados os argumentos e as conclusões. Ou seja, para o atual estágio do diálogo não se pode reconhecer a imprescritibilidade dos crimes cometidos pelos militares por supostamente se enquadrarem na definição de crimes contra a humanidade.

Vale apontar, no entanto, para futuros desenvolvimentos do debate, que até o momento o Brasil não aderiu à Convenção de 1968 sobre Imprescritibilidade dos Crimes de Guerra e dos Crimes Contra a Humanidade. Mas o Estatuto de Roma, internalizado pelo Decreto $\mathrm{n}^{\mathrm{o}}$ 4.388/2009, estabelece em seu Art. 29 a imprescritibilidade dos crimes de competência do Tribunal Penal Internacional, isto é os crimes de genocídio e os crimes contra a humanidade.

O outro argumento foi exposto na seção anterior e baseia-se na aplicação do Art. $5^{\circ}$, XLIV da CF/88. Depende, portanto, da data em que os crimes ocorreram para ser pertinente e de maior análise para aferir sua efetiva correção.

Destarte, do nosso ponto de vista de analista, os argumentos pela imprescritibilidade não podem ser acatados como corretos no presente estágio do diálogo.

\section{Princípio da Actio Nata}

O princípio da actio nata diz que o prazo prescricional (e, por vezes, o prazo decadencial) começa ou continua a correr a partir do momento em que nasce ou ressurge a possibilidade de se exercer ou discutir determinado direito em juízo. Ele pode ser extraído da leitura de dispositivos diversos espalhados pelo ordenamento jurídico brasileiro como, por exemplo, o Art. 27 do Código de Defesa do Consumidor, o Art. 200 do Código Civil, o Art 116 do Código Penal e da leitura que se faz do Art. 151 do Código Tributário Nacional (suspensão de exigibilidade também implica suspensão do prazo prescricional). 
A prescrição, como dito acima na seção sobre irretroatividade, visa a conferir segurança às situações de fato em conflito com a lei. Além disso, busca penalizar a inércia de quem não busca defender os seus direitos: dormentibus non sucurrit jus (o direito não socorre os que dormem), como esclarece o brocardo romano.

A hipótese que se levanta é de que, no caso concreto, o prazo prescricional não teria corrido, pela impossibilidade de se investigar penalmente os militares em virtude dos efeitos práticos da Lei de Anistia e do cenário político do país. Apesar de não ter sido tratada nesses termos, pode-se considerar que essa discussão foi tangenciada por discussão entre o Ministro Cezar Peluso e o Ministro Ayres Britto na ADPF 153 (Voto Min. Cezar Peluso, p.211/212).

Após o Min. Cezar Peluso dizer que todas as ações penais contra os militares estariam cobertas pela prescrição, o Min. Ayres Britto interveio:

“MINISTRO AYRES BRITTO - É que o Estado não poderia conseguir a perseguição por causa da lei. O Estado só desencadeia a persecução criminal com o afastamento do óbice da lei. Então, a questão da prescrição nem se coloca nesse momento.

MINISTRO CEZAR PELUSO (PRESIDENTE) - Não, Ministro, a prescrição se inicia da data da prática do crime, não é da data do reconhecimento de certo sentido da lei.

MINISTRO AYRES BRITTO - Sim, mas o Estado estava impedido de deflagrar a persecução.

MINISTRO CEZAR PELUSO - O Estado não tinha impedimento nenhum para fazê-lo. Se entendesse que a lei era incompatível com a Constituição, poderia, mas não o fez, ter intentado persecução penal. (...)" (ADPF 153, Voto Min. Cezar Peluso, p.212) 
Para fins deste mapa busca-se apenas delimitar o escopo jurídico do problema e apontá-lo como item relevante a ser enfrentado nos debates sobre prescrição.

\section{Investigação penal mesmo após a prescrição}

Como mencionado na discussão sobre as finalidades da pena, os Contra Militares podem arguir que a prescrição extingue a punibilidade, mas não impede que haja um processo penal apenas para declarar que um cidadão cometeu um crime. Desse modo seria possível atender à prevenção geral positiva, uma das finalidades da pena. Se é possível apenas declarar alguém como torturador no juízo cível (como foi admitido no processo $\mathrm{n}^{\circ}$ 0347718-08.2009.8.26.0000, ainda não encerrado, em trâmite perante o Tribunal de Justiça de São Paulo, caso do Coronel Ustra), porque não seria possível fazer o mesmo no juízo penal? Do ponto de vista do réu, seria inclusive mais recomendável vez que, a princípio, as exigências probatórias e o regime de preclusões do processo penal lhe são mais favoráveis.

As discussões sobre os impactos práticos desse entendimento precisam ser amadurecidas, inclusive sendo possível a limitação de casos em que faria sentido permitir uma ação penal meramente declaratória. Poder-se-ia, por exemplo, limitar essa possibilidade a casos dotados de um simbolismo importante, como o Caso Araguaia. A mensagem seria de que o ordenamento jurídico brasileiro entende o que ocorreu como um ilícito, mas deixa de punir por outras limitações importantes previstas na própria legislação.

\section{$\underline{\text { Provas e Responsabilidade Individual }}$}

Dúvida relevante é se seria possível, após tanto tempo, provar de maneira satisfatória a participação dos militares, e responsabilizá-los penalmente nos casos concretos. Se foi possível encontrar elementos para a elaboração dos diversos relatórios e dossiês até o momento, parece factível que se possa satisfazer as exigências do juízo penal em casos concretos. Tudo indica ainda que existem documentos em poder do exército (como o Projeto Orvil) que ainda não foram revelados e que poderiam esclarecer o que aconteceu. Os trabalhos das diversas Comissões da Verdade que estão sendo instauradas também pode colaborar bastante nesse sentido. 
Algumas observações devem ser relevantes quanto a esse trabalho de investigação. A exigência probatória tem de levar em consideração a forma pela qual os crimes foram cometidos pelos militares e pela oposição armada. Por exemplo, não se pode exigir tanto, documentalmente, de um desaparecimento forçado em que o próprio Estado nega a captura do indivíduo. No entanto, os testemunhos daqueles que sofreram com a repressão terão de ser analisados com cautela. É possível que algumas pessoas busquem se vingar dos militares e inventem histórias para incriminá-los. Não se deve assumir que a vítima ou suposta vítima esteja falando a verdade apenas pela posição que ocupa.

\section{$\underline{\text { Responsabilização Administrativa (I.1.B) }}$}

Como explicado no relato histórico, a responsabilização administrativa do Estado ocorreu de várias maneiras: (i) pelas mortes e desaparecimentos, de acordo com a Lei 9.140/1995; (ii) pelas torturas, houve casos de indenizações pagas por Comissões Estaduais; (iii) pela perda dos cargos, as indenizações pagas pela Lei de Anistia nos termos da Lei do Anistiado Político.

Há quem considere, como o jornalista Elio Gaspari, que a Lei do Anistiado Político seria uma "Bolsa-Ditadura"112, tão altos são os valores pagos. Com efeito, conforme o próprio relatório da Comissão de Anistia, até 2010 foram gastos mais de R \$ 250 milhões de reais com esse tipo de indenização. No mínimo, a atuação da Comissão e o valor das indenizações merecem atenção.

Vale também examinar a potencial desproporção entre os valores pagos aos familiares dos mortos e desaparecidos, e os valores pagos aos torturados e aos anistiados por conta da perda dos cargos. Não se encontraram pesquisas nesse sentido, apesar do escalonamento dos valores poder fornecer um critério para julgar sua adequação.

\footnotetext{
${ }^{112}$ GASPARI, Elio. Bolsa Ditadura se transformou em indústria. Folha de São Paulo / O Globo. 28 de junho de 2009. Disponível em http://www.conjur.com.br/2009-jun-28/bolsa-ditadura-transformou-catedralprivilegios-malandragem. Acesso em 04 de janeiro de 2012.
} 


\section{Responsabilização Civil (I.1.C)}

A responsabilização civil do Estado também é tema que merece maior atenção. Conforme se pode verificar da breve pesquisa apresentada no Apêndice III, há jurisprudência do Superior Tribunal de Justiça que diz que pedidos de dano moral por tortura e outras atrocidades do regime militar são imprescritíveis.

Para que se tenha um quadro real de quanto o Estado está pagando, seria necessário investigar o número de ações e os valores envolvidos. Além disso, várias questões dogmáticas merecem debate, por exemplo: (a) O Estado pode ser obrigado a pagar valores complementares nos casos em que já houve pagamento de indenização administrativa?; (b) Quem são os legitimados a pedir dano moral, apenas os afetados diretamente, parentes?; (c) Há diferenças de tratamento para casos de tortura, morte e desaparecimento forçado?

A responsabilização civil dos militares também é objeto de debate. Tanto por ação ajuizada por familiares contra um militar (Família de Eduardo Merlino x Coronel Ustra, processo $n^{\circ}$ 583.00.2010.175507-9, em trâmite perante o Tribunal de Justiça de São Paulo) quanto pelo regresso do Estado contra os responsáveis pelas atrocidades, para que reembolsem os gastos das indenizações administrativas (Ministério Público Federal $\mathrm{x}$ União Federal, Coronel Ustra e Audir dos Santos Maciel, processo $\mathrm{n}^{\circ}$ 001141428.2008.4.03.6100, em trâmite perante o Tribunal Regional Federal da $3^{\text {a }}$ Região). Ambos os processos mencionados têm referência mais completa no Apêndice III.

Em conclusão, faltam estudos sobre as implicações civis do que ocorreu no regime militar.

\section{$\underline{\text { Verdade e Memória (II) }}$}

Como relatado, a busca da verdade é um problema que foi enfrentado principalmente pela CEMDP e hoje recebe atenção da Comissão Nacional da Verdade e de outras comissões da verdade criadas em âmbitos diversos. Deve-se atentar para as limitações do trabalho da CEMDP, que não podia investigar a fundo as circunstâncias das mortes, reconstruindo histórias e nomeando responsáveis. Cabia à CEMDP apenas 
verificar se a morte tinha ocorrido em situação na qual existiria domínio do indivíduo pelos agentes estatais. Tais limitações estão sendo superadas pelo escopo de trabalho ampliado das Comissões da Verdade.

Muitas discussões - que não serão detalhadas aqui - são travadas sobre supostos documentos em poder do Exército e arquivos do DOPS e do DOI/CODI que poderiam ajudar a esclarecer os acontecimentos do regime militar. Todos os documentos que existiram foram preservados? Foi concedido acesso a todos? Quais são os óbices ao acesso? Vale destacar no mínimo o Projeto Orvil como documento relevante que ainda não veio a público. O desenvolvimento desses debates depende fortemente do trabalho das Comissões da Verdade, que está apenas começando. De qualquer modo, como auxílio a discussões futuras, elaborou-se no Apêndice III breve histórico das leis sobre sigilo de documentos no país, contendo inclusive a recente Lei de Acesso à Informação (Lei $\mathrm{n}^{\circ}$ 12.527 de 18 de novembro de 2011).

Ainda quanto ao problema da verdade, chegaram a ser travadas discussões sobre a existência, ou não, do direito à verdade (SWENSSON JR., p. 102/106), as quais podem ser consideradas superadas pela entrada em vigor da Lei 12.528/2011, que criou a Comissão da Verdade e reconhece expressamente em seu Art. $1^{\circ}$ os direitos à memória e à verdade histórica.

Foram travadas também discussões sobre a possibilidade do processo judicial, incluindo o de cunho criminal, ser usado como instrumento para a busca da verdade. No geral, encontraram-se severas críticas a esse instrumento como meio adequado para a busca da verdade, em virtude de todas as suas limitações, como o regime de preclusões, a limitação ao trabalho das partes, falta de celeridade, etc. O modelo das Comissões da Verdade, desenhadas para desempenhar especificamente esse papel com poderes ampliados se mostrou como uma alternativa melhor.

Existem ainda discussões sobre a existência de uma verdade a ser buscada (teórica) e, se existir, sobre as dificuldades em encontrá-la (práticas). A leitura que nos parece deva ser feita do direito à verdade é a do direito aos melhores esforços de reconstrução histórica de um período, o que engloba o maior acesso possível a documentos, testemunhas e 
também a imparcialidade de apresentação dos resultados. Não se busca "A Verdade" absoluta, mas a descrição mais próxima possível, com reconhecimento de suas limitações.

Destaque-se que a noção de imparcialidade na descrição histórica traz implicações concretas para o mencionado debate sobre o escopo dos trabalhos da Comissão da Verdade. Uma história imparcial deve revelar não apenas as atrocidades cometidas pelos militares, mas também pela oposição armada. O Estado não deve permitir que perdurem as distorções históricas apontadas no começo deste capítulo: que havia uma guerra revolucionária, que a oposição armada era um "braço armado" da esquerda e que que sua luta se tratou de uma "resistência democrática". O papel dos militares e de cada grupo de esquerda deve ser esclarecido, a fim de que as pessoas possam julgar livremente e com o máximo de informação as suas ações. Selecionar os fatos e contar a versão de apenas uma das partes do conflito é realizar um prejulgamento, e estaria bem longe de algo que se pudesse chamar de "verdade histórica". A prática do Direito bem nos ensina que toda história tem dois lados.

Quanto às dificuldades práticas, não se pode dizer muito sem entrar nos detalhes concretos. Por ora, basta reconhecer que elas existem, e que devem ser feitos os melhores esforços para que elas sejam superadas. O desenho da Comissão Nacional da Verdade e a Lei de Acesso à Informação tentam justamente superar essas dificuldades.

Por fim, o problema da preservação da memória vem diretamente associado ao problema da verdade. Até o momento, os relatórios e dossiês, oficiais e extra-oficiais, bem como os próprios processos judiciais que discutem o tema, têm sido o caminho encontrado para manter viva a memória do regime militar. 


\section{CONCLUSÕES}

O presente trabalho teve um duplo objetivo, prático e teórico. Em termos práticos, sistematizou as discussões sobre a responsabilização dos militares e do Estado por acontecimentos do regime militar, bem como sobre a busca da verdade e a preservação da memória. Em termos teóricos, buscou apresentar os principais conceitos e ferramentas da Teoria da Argumentação, tentando adaptá-las na medida do possível às necessidades da argumentação jurídica. A aplicação da teoria à prática almejou beneficiar ambas. Cabem alguns comentários sobre a realização dos objetivos pretendidos.

Quanto ao objetivo prático, foi elaborado um Mapa Argumentativo apresentando de maneira sistemática e organizada os debates acerca da responsabilização, da verdade e da memória sobre o regime militar. O Mapa em seu nível mais geral, o das questões, nos mostra a amplitude dos debates. Ele nos serve ainda de modelo para pensar adequadamente o tratamento jurídico que se deve dar a um caso difícil. Precisamos, primeiro, identificar os nossos objetivos mais gerais. No caso, de um lado, responsabilizar o Estado e os militares e, de outro, buscar a verdade e preservar a memória. Assim foi feita a divisão inicial dos debates no Mapa.

Na sequência, os debates sobre a responsabilização foram organizados conforme o tipo: criminal, administrativa e civil. São os meios mais gerais que o ordenamento jurídico oferece para cumprir a tarefa de responsabilizar. De maneira análoga, discutiram-se também os meios pelos quais seria buscada a verdade. No entanto, desde logo as fortes críticas à utilização da via judicial a excluíram como meio de buscar a verdade e levaram à elaboração de Comissões, desenhadas especificamente para esse fim. Em suma, estabelecidos os fins, questionaram-se os meios.

Estabelecidos os meios, instauraram-se debates mais específicos sobre cada um deles. Seria realmente possível a responsabilização criminal, administrativa ou civil, tendo em vista a Lei de Anistia? As discussões criminais concentram-se justamente nessa objeção. Diferentemente, a possibilidade da responsabilização administrativa e civil foi reconhecida, passando as discussões a se focar em delimitações mais específicas dos casos em que são cabíveis e no quantum a ser pago. Em relação ao 
problema da verdade e da memória, mencionam-se as dificuldades teóricas (o que é essa verdade que estamos buscando?) e práticas (tempo transcorrido, acesso a documentos, etc.) que serão enfrentadas pelas Comissões da Verdade no desenvolvimento de suas atividades.

O Mapa mostra ainda que as discussões sobre responsabilização poderiam ser aprofundadas. Em relação aos meios de responsabilização, pode-se pensar em alternativas não jurídicas, de cunho moral ou sócio-político. Claro que seriam necessárias discussões para precisar o significado dessas formas de responsabilização e verificar se a responsabilização jurídica não acarretaria consequências morais ou sóciopolíticas. É importante ainda não esquecer que estão sendo discutidos os meios de responsabilização do Estado e dos militares por um mesmo conjunto de fatos. Não se deve perder de vista o todo para não correr o risco de que as consequências da responsabilização sejam excessivas. Imagine-se, por exemplo, que o Judiciário entenda que devam ser pagos valores a título de dano moral pelas torturas para além dos valores já pagos pelas Comissões Estaduais de indenização. As cifras podem aumentar muito e a suficiência dos valores tem de ser debatida com rigor. Por fim, atente-se para as possíveis discussões sobre Política, Moral, Justiça e Direito, mencionadas no Mapa.

Assim, a divisão das discussões do Mapa percorre aproximadamente o seguinte caminho: (i) identificação dos objetivos; (ii) identificação dos meios para atingir os objetivos; (iii) verificação da possibilidade de utilização dos meios; (iv) discussão dos detalhes e problemas relativos à utilização do meio; (v) caso mais de um meio seja utilizado ao mesmo tempo, avaliação das consequências de sua utilização conjunta. Trata-se de uma estrutura simples de organização ${ }^{113}$ e, por isso, muito eficaz.

O Mapa, em níveis mais detalhados, serve também para mostrar que o grau de amadurecimento das discussões é bastante variável. Há pouca discussão sobre a responsabilização civil do Estado e dos militares. A atuação da Comissão de Anistia do Ministério da Justiça e das Comissões Estaduais que pagaram indenizações também é pouco estudada, apesar da relevância dos valores envolvidos. Ainda que as possibilidades de pagamento tenham sido legalmente previstas, muitos problemas só são

\footnotetext{
${ }^{113}$ Cuja estrutura lembra as discussões previstas no esquema do argumento pragmático e no esquema do argumento pelo objetivo da Lei.
} 
encontrados nos casos concretos, como, por exemplo, os standards de provas exigidos para a concessão das indenizações. Estariam esses órgãos facilitando ou dificultando o acesso à indenização? Não encontramos estudos que discutam esses problemas.

A responsabilização penal concentra a maior parte das discussões, mas focadas no problema da anistia dos militares. Pouco se discute sobre retroatividade ou prescrição. Nossas principais fontes de consulta para essas objeções foram processos judiciais.

Devido à intensidade do debate quanto à anistia dos militares, vale retomarmos brevemente as conclusões a que chegamos na exposição do Mapa no Capítulo 3. De maneira contrária ao Acórdão do STF na ADPF 153, concluímos que os militares não foram beneficiados pela Lei de Anistia. Em síntese, o esforço de interpretação e argumentação realizado mostra contextualmente que "motivação política" era a motivação de contestar o regime. Revela ainda que a Lei de Anistia tinha por objetivo excluir crimes violentos do seu âmbito de aplicação (conforme sua redação e razões do processo legislativo). Por fim, para saber se um crime político ou conexo foi efetivamente anistiado ele deve ser analisado sob o duplo critério da preponderância das razões e da atrocidade dos meios. Torturas, execuções e desaparecimentos forçados não podem ser considerados anistiados diante disso.

A maior chave de interpretação daqueles que defendem a tese de que os militares foram beneficiados pela anistia baseia-se na ideia de que houve uma negociação política que levou à anistia recíproca. Como debatido detalhadamente no Mapa Argumentativo, não se verificam indícios a suportar a existência da suposta negociação e sequer a anistia foi recíproca, tendo sido excluídos do rol de beneficiados membros da oposição armada. O governo militar repetia que não poderiam ser anistiados "crimes contra a humanidade", ou seja, atos atrozes e violentos. Para ser jurídica, essa regra tem de valer para a oposição armada e para os militares.

Gostaríamos de destacar que essas conclusões indicam ainda a possibilidade de outro resultado potencialmente impopular. Alguns crimes cometidos pela oposição armada que foram historicamente considerados anistiados podem também ter sido excluídos da anistia. Devemos lembrar que a interpretação dada ao Art. $1^{\circ}, \S 2^{\circ}$ da Lei 
de Anistia criou uma distinção entre condenados e não condenados por crimes violentos, excluindo os primeiros da anistia e beneficiando os últimos. Assim, os "não condenados" por crimes violentos praticados por motivação política foram considerados anistiados.

Entretanto, para alguém ser anistiado o crime deve ser considerado político ou conexo, independentemente de condenação. Se levarmos em consideração a interpretação da Lei de Anistia exposta acima, especialmente o duplo critério da preponderância das razões e atrocidade dos meios, há a possibilidade de se concluir que alguns crimes cometidos pela oposição armada que foram considerados anistiados não poderiam ter sido. Lembre-se, a título de ilustração, do atentado do aeroporto de Guararapes, em que inocentes morreram. Se o atentado realmente foi cometido pela oposição armada, pode ser considerado atroz e excluído o seu caráter político, sendo os responsáveis retirados do rol de beneficiados pela Lei de Anistia. Não encontramos, nas pesquisas realizadas, discussão dessa possibilidade. Pela falta de maturação, por enquanto apenas sugerimos que esta questão seja debatida.

Quanto ao objetivo teórico, o Capítulo 1 apresentou uma exposição compreensiva dos principais conceitos e ferramentas da Teoria da Argumentação baseada principalmente na obra de Douglas Walton, tentando, quando possível, contribuir para seu aprimoramento. Espera-se que este texto em português, que também almejou ser claro e sintético, ajude na difusão da Teoria da Argumentação no Brasil. O Capítulo 2 apresentou os resultados que obtivemos na tentativa de adaptar as ferramentas da Teoria da Argumentação para a Argumentação Jurídica, com foco na elaboração de alguns esquemas de argumentos. Apesar de modestos, os resultados nos foram muito úteis. Acreditamos que os esquemas de argumento de tradição, de aplicação da norma jurídica, pelo objetivo da Lei e de exceção tenham um bom potencial de auxílio prático a operadores do Direito.

Como o trabalho objetivou que a teoria beneficiasse a prática e vice-versa, é importante pontuar que ele não foi escrito na ordem em que foi apresentado. Foram inúmeras versões do Mapa Argumentativo e muitas idas e vindas entre Capítulo 2 e Capítulo 3. Espera-se que o diagrama e os argumentos divididos claramente em premissas e conclusões no Apêndice IV ajudem a tornar mais explícita essa conexão. Os 
argumentos do Mapa foram identificados, analisados, avaliados, elaborados e reelaborados a partir de reflexões baseadas nos esquemas de argumento do Capítulo 2. Não teríamos atingido o grau de sistematização e clareza que esperamos ter conseguido sem a consciência daquelas ferramentas e sem a base teórica do Capítulo 1.

Ainda há muito a ser discutido quanto aos acontecimentos do regime militar, a sua responsabilização, a busca da verdade e a preservação da memória. Há ainda mais trabalho a ser realizado para que seja criado um conjunto de ferramentas de argumentação jurídica simples e útil para os operadores do Direito. A nossa expectativa é que esse trabalho tenha contribuído para ambos os objetivos e permita que as discussões futuras sejam realizadas de maneira mais organizada dentro de quadros gerais claros. Esperamos também que tenhamos conseguido reforçar a importância da teoria para a prática e vice-versa. 


\section{REFERÊNCIAS BIBLIOGRÁFICAS}

\section{Livros e Textos}

ALEXY, Robert. Teoria dos Direitos Fundamentais. 2a Ed. São Paulo: Malheiros, 2011.

ANDERSON, David R.; SWEENEY, Dennis J.; WILLIAMS, Thomas A. Estatística Aplicada à Administração e Economia. $2^{\mathrm{a}}$ Ed. São Paulo: Cengage Learning, 2008.

ARISTÓTELES. The Complete Works of Aristotle (Revised Oxford Translation). Organização de Jonathan Barnes. Princeton: Princeton University Press, v. 1 e v. 2, 1995.

ARQUIDIOCESE DE SÃO PAULO. Brasil: Nunca Mais. 39ª Ed. Petrópolis: Vozes, 2011.

ATIENZA, Manuel. As Razões do Direito. São Paulo: Landy, 2002.

BENSON MATES. Elementary Logic. 2a Ed. New York: Oxford University Press, 1972.

BERTI, Enrico. As Razões de Aristóteles. $2^{\text {a }}$ Ed. São Paulo: Loyola, 2002.

BERTI, Enrico. Aristóteles no Século XX. São Paulo: Loyola, 1997.

BRASIL. Ministério da Justiça. Comissão de Anistia. Relatório Anual da Comissão de Anistia 2010. Brasília: Comissão de Anistia, 2010.

BRASIL. Secretaria Especial dos Direitos Humanos. Comissão Especial sobre Mortos e Desaparecidos Políticos. Direito à Verdade e à Memória. Brasília: Secretaria Especial de Direitos Humanos, 2007.

COMBLIN, Joseph. A Ideologia da Segurança Nacional: o poder militar na América Latina. Rio de Janeiro: Civilização Brasileira, 1978.

COMISSÃO DE FAMILIARES DE MORTOS E DESPARECIDOS POLÍTICOS. Dossiê Ditadura: mortos e desaparecidos políticos no Brasil (1964-1985). $2^{\text {a }}$ Ed. São Paulo: Imprensa Oficial, 2009.

DWORKIN, Ronald. Levando os Direitos a Sério. São Paulo: Martins Fontes, 2002.

DWORKIN, Ronald. Uma Questão de Princípio. São Paulo: Martins Fontes, 2005.

EEMEREN, Frans H. Van; GROOTENDORST, Rob; JACKSON, Sally; e JACOBS, Scott. Reconstructing Argumentative Discourse. Tuscaloosa: University of Alabama Press, 1993.

FERRAZ JÚNIOR, Tércio Sampaio. A Hipótese do Legislador Racional e a Noção de Justiça. Cadernos de Direito GV, v. 6, 2009, p.21-41. 
FERRAZ JÚNIOR, Tércio Sampaio. Introdução ao Estudo do Direito: técnica, decisão, dominação. $6^{\mathrm{a}}$ Ed. São Paulo: Atlas, 2010.

FETERIS, Eveline T. The Rational Reconstruction of Argumentation Referring to Consequences and Purposes in the Application of Legal Rules: A Pragma Dialectical Perspective. Argumentation, 19, 2005, p. 459-470.

FETERIS, Eveline T. e KLOOSTERHUIS, Harm. The Analysis and Evaluation of Legal Argumentation: Approaches from Legal Theory and Argumentation Theory. Studies in Logic, Grammar and Rhetoric, 16 (29), 2009, p. 307-331.

GOLDEN, James e PILOTTA, Joseph (orgs). Practical Reasoning in Human Affairs. Studies in honor of Chaim Perelman. Dordrecht: Reidel, 1986.

GORDON, Thomas F. An Overview of the Carneades Argumentation Support System. in C.W. Tindale e C. Reed Dialectics, Dialogue and Argumentation. An Examination of Douglas Walton's Theories of Reasoning. College Publications, 2010, p. 145-156. Disponível em http://www.tfgordon.de/publications. Acesso em 18 de fevereiro de 2012.

GORDON, Thomas F. Visualizing Carneades argument graphs. Law, Probability and Risk, 6, 1-4 (2007), p. 109-117. Disponível em http://www.tfgordon.de/publications. Acesso em 01 de fevereiro de 2012.

GORDON, Thomas F.; PRAKKEN, Henry; e WALTON, Douglas. The Carneades model of argument and burden of proof. Artificial Intelligence, 171, 10-11 (2007), p. 875-896. Disponível em http://www.tfgordon.de/publications. Acesso em 01 de fevereiro de 2012.

GORDON, Thomas F.; WALTON, Douglas. A formal model of legal proofs standard and burdens. in EEMERAN, Frans H. Van; GARSSEN, B.; BLAIR; J. A. \& MITCHELL, G. R. (Eds.), 7th Conference on Argumentation of the International Society for the Study of Argumentation (ISSA 2010). Amsterdam: Sic Sac, 2011, p. 644-655.

GRÁCIO, Rui Alexandre. Racionalidade Argumentativa. Coimbra: ASA, 1993.

GÜNTHER, Klaus. Crítica da Pena I (2004). Revista Direito GV nº4, jul-dez 2006, p. 187-203.

GÜNTHER, Klaus. Crítica da Pena II (2005). Revista Direito GV nº5, jan-jun 2007, p. 137-149.

HART, Herbert L. A. O Conceito de Direito. $2^{\mathrm{a}}$ Ed. Lisboa: Fundação Calouste Gulbekian, 2003.

KELSEN, Hans. Teoria Pura do Direito. $7^{\circ}$ Ed. São Paulo: Martins Fontes, 2006.

MACCORMICK, Neil. Retórica e o Estado de Direito. Rio de Janeiro: Elsevier, 2008. 
MACCORMICK, Neil e WEINBERGER, Ota. An Institutional Theory of Law: new approaches to legal positivism. Dordrecht: D. Reidel, 1986.

MACCORMICK, Neil. Institutions of Law: an essay in legal theory. New York: Oxford University, 2007.

MANELI, Mieczyslaw. A Nova Retórica de Perelman: Filosofia e Metodologia para o Século XXI. São Paulo: Manole, 2004.

MEYER, Michel. A retórica. São Paulo: Ática, 2007.

MEZAROBBA, Glenda. Um Acerto de Contas com o Futuro: a anistia e suas consequências: um estudo do caso brasileiro. São Paulo: Associação Editorial Humanitas - FAPESP, 2006.

MEZAROBBA, Glenda. O Preço do Esquecimento: as reparações pagas às vítimas do regime militar (uma comparação entre Brasil, Argentina e Chile). Tese (Doutorado em Ciência Política). Faculdade de Filosofia, Letras e Ciências Humanas da Universidade de São Paulo - FFLCH/USP, 2007.

MIRANDA, Nilmário; TIBÚRCIO, Carlos. Dos filhos deste solo: mortos $e$ desaparecidos políticos durante a ditadura militar, a responsabilidade do Estado. $2^{\mathrm{a}}$ Ed. São Paulo: Perseu Abramo, 2008.

NASSER, Salem Hikmat. Jus Cogens: Ainda esse desconhecido. Revista DIREITO GV no 2, jul-dez 2005, p. 161-178.

PERELMAN, Chaïm e OLBRECHTS-TYTECA, Lucie. Tratado da Argumentação: A Nova Retórica. $2^{\text {a }}$ Ed. São Paulo: Martins Fontes, 2005.

PERELMAN, Chaïm. Ética e Direito. São Paulo: Martins Fontes, 2000.

PERELMAN, Chaïm. Lógica Jurídica. 2a Ed. São Paulo: Martins Fontes, 2004.

PERELMAN, Chaïm. Retóricas. 2a Ed. São Paulo: Martins Fontes, 2004.

PERELMAN, Chaïm. The Realm of Rhetoric. Notre Dame: University of Notre Dame Press, 1982.

PERRUSO, Camila Akemi. O Desaparecimento Forçado de Pessoas no Sistema Interamericano de Direitos Humanos - Direitos Humanos e Memória. Dissertação (Mestrado em Direito). Faculdade de Direito da Universidade de São Paulo, São Paulo, 2010.

PRAKKEN, Henry. Argumentation without arguments. Argumentation, 25, 2011, p. 171-184. Disponível em http://www.staff.science.uu.nl/ prakk101/. Acesso em 18 de fevereiro de 2012. 
PÜSCHEL, Flávia Portella. A Função Punitiva da Responsabilidade Civil no Direito Brasileiro: Uma Proposta de Investigação Empírica. Revista Direito GV nº6, jul-dez 2007, p. 17-36.

RAMOS, André de Carvalho. Responsabilidade Internacional por Violação de Direitos Humanos:Seus elementos, a reparação devida e sanções possíveis. Teoria e prática do Direito Internacional. Rio de Janeiro: Renovar, 2004.

REBOUL, Olivier. Introdução à Retórica. 2a Ed. São Paulo: Martins Fontes, 2004.

REIS, Daniel Aarão. Ditadura Militar, esquerdas e sociedade. $3^{\mathrm{a}}$ Ed (e-book). Rio de Janeiro: Jorge Zahar, 2012.

ROWE, Glenn W. A. e REED, Chris A. Araucaria User's Manual. Version 3.1. Disponível em http://araucaria.computing.dundee.ac.uk/doku.php. Acesso em $18 \mathrm{de}$ fevereiro de 2012.

ROWE, G.W.A.; REED, C.A.; e KATZAV, J. "Araucaria: Marking Up Argument" in Working Notes of the European Conference on Computing and Philosophy, 2003, Glasgow. Disponível em http://www.arg.dundee.ac.uk/people/chris/publications/showbyyear.php. Acesso em 01 de fevereiro de 2012.

SANTOS, Cecília Macdwell; TELES, Edson; TELES, Janaína de Almeida (Orgs.). Desarquivando a Ditadura: Memória e Justiça no Brasil. 2 volumes. São Paulo: Hucitec, 2009.

SILVA, Geraldo Eulálio do Nascimento; ACCIOLY, Hildebrando; CASELLA, Paulo Borba. Manual de Direito Internacional Público. $16^{\mathrm{a}}$ Ed., revista, atualizada e ampliada. São Paulo: Saraiva, 2008.

SILVA, Virgílio Afonso da. Princípios e regras: mitos e equívocos acerca de uma distinção. Revista Latino-Americana de Estudos Constitucionais 1 (2003), p. 607-630.

SILVA, Virgílio Afonso da. Ponderação e objetividade na interpretação constitucional in MACEDO JR., Ronaldo Porto e BARBIERI, Catarina Helena Cortada (Orgs.) Direito e interpretação: racionalidades e instituições. São Paulo: Direito GV/Saraiva, 2011, p. 363-380.

SOARES, Inês Virgínia Prado; KISHI, Sandra Akemi Shimada (Orgs.). Memória e Verdade: A justiça de transição no estado democrático brasileiro. Belo Horizonte: Fórum, 2009.

SWENSSON JUNIOR, Lauro Joppert et al. Justiça de Transição no Brasil: Direito, Responsabilização e Verdade. São Paulo: Saraiva, 2010.

TELES, Janaína (Org.). Mortos e desaparecidos políticos: reparação ou impunidade? São Paulo: Humanitas FFLCH/USP, 2000.

TOULMIN, Stephen. Os usos do argumento. $2^{\mathrm{a}}$ Ed. São Paulo: Martins Fontes, 2006. 
USTRA, Carlos Alberto Brilhante. A Verdade Sufocada: a história que a esquerda não quer que o Brasil conheça. 8 ${ }^{\text {a }}$ Ed. Brasília: Editora Ser, 2012.

VEÇOSO, Fabia Fernandes Carvalho. Entre absolutismo de direitos humanos e história contextual: aspectos da experiência da Corte Interamericana de Direitos Humanos. Tese (Doutorado em Direito). Faculdade de Direito da Universidade de São Paulo, São Paulo, 2012.

VIEHWEG, Theodor. Tópica e Jurisprudência. Trad. de Tércio Sampaio Ferraz Jr. Brasília: Departamento de Imprensa Nacional, 1979.

VIEHWEG, Theodor. Topica y Filosofia del Derecho. $2^{\text {a }}$ Ed. Barcelona: Gedisa, 1997.

VIEIRA, Oscar Vilhena. Supremo Tribunal Federal: Jurisprudência política. $2^{\mathrm{a}}$ Ed. São Paulo: Malheiros, 2002.

WALDRON, Jeremy. The core of the case against judicial review. 115 Yale L.J., 2006, p.1346-1406.

WALTON, Douglas. Argument Mining by Applying Argumentation Schemes. Studies in Logic, 4(1), p. 38-64, 2011. Disponível em http://www.studiesinlogic.net/english/ShowArticle.asp?ArticleID=231. Acesso em 18 de fevereiro de 2012.

WALTON, Douglas N. Fundamentals of Critical Argumentation. New York: Cambridge University Press, 2006.

WALTON, Douglas N. Lógica Informal: Manual de Argumentação Crítica. São Paulo: Martins Fontes, 2006.

WALTON, Douglas N.; REED, Chris; MACAGNO, Fabrizio. Argumentation Schemes. New York: Cambridge University Press, 2008.

WEINREB, Lloyd L. A Razão Jurídica. São Paulo: Martins Fontes, 2008.

ZILLI, Marcos. "O último tango?" in Memória e Verdade: A justiça de transição no Estado Democrático Brasileiro. Coords. SOARES, Inês Virgínia Prado e KISHI, Sandra Akemi Shimada. Belo Horizonte: Fórum, 2009

\section{Jurisprudência}

\section{II.1 Nacional}

TRF3, AI 483.607, processo n ${ }^{\circ}$ 0024081-71.2012.4.03.0000/SP, Rel. Des. Fed. Nery Júnior. Decisão monocrática. Decisão disponibilizada no DJE em 30 de agosto de 2012. (http://www.trf3.jus.br/, acesso em 10 de setembro de 2012) 
STF, ADPF 153 / DF, Rel. Min. Eros Grau. Plenário. Votação por maioria. Julgada em 29 de abril de 2010. Acórdão publicado no DJE em 06 de agosto de 2010. (http://www.stf.jus.br , último acesso em 12 de dezembro de 2012).

STF, HC 73.451-1 / RJ, Rel. Min. Maurício Corrêa. 2a Turma. Votação unânime. Julgada em 8 de abril de 1997. (http://www.stf.jus.br , último acesso em 12 de dezembro de 2012)

STF, Extradição 855-2 / República do Chile, Rel. Min. Celso de Mello. Plenário. Votação unânime (parte dos pedidos) e votação por maioria (parte dos pedidos). Julgada em 26 de agosto de 2004. (http://www.stf.jus.br , último acesso em 12 de dezembro de 2012)

STF, Extradição 1.085 / República Italiana, Rel. Min. Cezar Peluso. Plenário. Votação por maioria. Julgada em 16 de dezembro de 2009. (http://www.stf.jus.br , último acesso em 12 de dezembro de 2012)

\section{II.2 Internacional}

CORTE INTERAMERICANA DE DIREITOS HUMANOS. Gomes Lund e outros ("Guerrilha do Araguaia") x Brasil. Sentença de exceções preliminares, mérito, reparações e custas. Julgada em 24 de novembro de 2010. (Disponível em http://www.corteidh.or.cr/docs/casos/articulos/seriec_219_por.pdf. Acesso em 05 de janeiro de 2012)

SUPREMA CORTE DOS ESTADOS UNIDOS DA AMÉRICA. Brown vs. Board of Education, 347 U.S. 483, 1954.

\section{Documentos}

Manifesto Público em prol do Debate Público Nacional sobre o alcance da Lei da Anistia (Versão provisória). Disponível em http://www.unisinos.br/blog/ppgdireito/files/2008/08/manifesto_com_assinatura_dos_ju ristas_13-081.pdf. Acesso em 05 de janeiro de 2012.

ESTATUTO DEL TRIBUNAL MILITAR INTERNACIONAL DE NUREMBERG, de 06 de outubro de 1945. (texto em espanhol) Disponível em http://www.ehu.es/ceinik/tratados/7TRATADOSRELATIVOSACRIMENESDEGUER RA/CG73.pdf. Acesso em 05 de janeiro de 2012.

\section{Sites}

\section{IV.1 Programas de Argumentação}

Araucaria Website

http://araucaria.computing.dundee.ac.uk/doku.php 
Carneades Website

http://carneades.berlios.de/

\section{IV.2 Jornais e Revistas}

$\underline{\text { Acervo Digital Veja }}$

http://veja.abril.com.br/acervodigital/

Acervo Digital Folha

http://acervo.folha.com.br

$\underline{\text { Acervo Digital Jornal do Brasil }}$

http://news.google.com/newspapers?nid=0qX8s2k1IRwC

\section{IV.3 Textos de Argumentação}

Douglas Walton's Publications (Papers)

http://www.dougwalton.ca/papers.htm

Chris Reed's Publications

http://www.arg.dundee.ac.uk/people/chris/publications/showbyyear.php

$\underline{\text { Thomas F. Gordon's Publications }}$

http://www.tfgordon.de/publications

$\underline{\text { Henry Prakken's Publications }}$

http://www.staff.science.uu.nl/ prakk101/

\section{IV.4 Instituições - Anistia}

$\underline{\text { Ministério da Justiça - Comissão de Anistia }}$

http://portal.mj.gov.br/data/Pages/MJ20BF8FDBPTBRNN.htm 
$\underline{\text { Secretaria de Direitos Humanos - Série Memória e Verdade }}$

http://www.sedh.gov.br/clientes/sedh/sedh/biblioteca/serie-direito-a-memoria-e-averdade

Comissão Nacional da Verdade

http://www.cnv.gov.br/

Comissão da Verdade da Câmara Municipal de São Paulo

http://www.camara.sp.gov.br/index.php?option=com_content $\& v i e w=a r t i c l e \& i d=11510$ : comissao-da-verdade $\&$ Itemid $=300$

Comissão de Familiares de Mortos e Desaparecidos Políticos

http://www.desaparecidospoliticos.org.br/

Grupo Tortura Nunca Mais

São Paulo: http://www.torturanuncamais-sp.org/site/

Rio de Janeiro: http://www.torturanuncamais-rj.org.br/ 


\section{APÊNDICE I \\ MAPA CONCEITUAL - CAPÍTULO 1}

\section{Seção I.1 - Conceitos Básicos}

Argumento, premissas e conclusão: Argumento é um sistema de proposições que nos permite, por meio de um processo de inferência, partir de uma proposição ou conjunto de proposições $A$, denominado premissas, para uma proposição B, denominada conclusão.

Argumentar: oferecer razões para sustentar ou criticar uma proposição.

Argumentação: conjunto de argumentos oferecido pelas partes no diálogo para sustentar o seu ponto de vista.

Diálogo, questão, tese, ponto de vista: conversação orientada por um objetivo, na qual dois participantes (no caso mínimo) agem por meio de turnos. O diálogo envolve uma questão (issue) a ser debatida e ao menos uma tese sobre essa questão (thesis). Cada participante apresenta um ponto de vista (viewpoint) sobre a questão.

\section{Seção I.1.A - Tipos de Generalização}

Afirmação Específica: proposição que afirma alguma coisa sobre um indivíduo.

Generalização: proposição que atribui alguma propriedade a um grupo de coisas individuais.

Generalização universal: proposição que afirma alguma coisa sobre todos os indivíduos de um determinado tipo. Também conhecida como absoluta ou estrita.

Generalização indutiva: proposição que afirma que certo número de indivíduos (que pode ser especificado ou não) tem uma determinada propriedade. 
Numérica ou Não-Numérica: A generalização indutiva pode ser numérica ou não numérica, caso possua um número exato (ou intervalo numérico) determinado ou não possua.

Probabilidade: Algum número entre 0 e 1 que meça a possibilidade de que alguma proposição seja verdadeira ou falsa.

Generalização derrotável: proposição que afirma que determinado tipo de indivíduos geralmente tem certa propriedade, estando essa afirmação sujeita a exceções. Ela recebe esse nome justamente por ter a característica de poder ser derrotada em casos especiais, mas ainda assim ser mantida para os casos típicos ou standard.

Falácia da qualificação ignorada (fallacy of ignoring qualifications) ou falácia da generalização apressada (fallacy of hasty generalization): Sustentar erroneamente que a generalização se mantém por não avaliar adequadamente as circunstâncias concretas que justificam o abandono da generalização.

Contra exemplo: caso em que a regra posta pela generalização falha.

Caso Padrão: caso pressuposto na utilização de uma generalização derrotável ou indutiva. Compreende mais propriedades do que aquelas afirmadas na própria generalização.

Afirmação existencial (existential statement): Trata-se de afirmação que diz que "pelo menos um indivíduo possui a propriedade/característica X”.

\section{Seção I.1.B - Tipos de Argumento}

Argumento dedutivo: Argumento no qual se as premissas são verdadeiras, a conclusão é necessariamente verdadeira do ponto de vista lógico. Em outras palavras, há argumento dedutivo quando for logicamente impossível que as premissas sejam verdadeiras e a conclusão falsa ao mesmo tempo. Se o argumento dedutivo for estruturalmente correto diz-se que ele é válido e, no caso contrário, inválido. 
Condicional correspondente: formulação do argumento dedutivo obtida ao colocá-lo na forma "Se __, Então ___. A primeira parte do condicional, conhecida como antecedente, é composta pelas premissas e a segunda parte, conhecida como consequente, é composta pela conclusão.

Argumento indutivo: Argumento no qual se as premissas são verdadeiras a conclusão é provavelmente verdadeira, mas possivelmente falsa. A ligação entre as premissas e a conclusão não é tão estrita. Os argumentos indutivos são baseados em probabilidade.

Argumento derrotável: Argumento cuja conclusão parece verdadeira, dadas as aparências do caso, ou seja, dadas as informações e conhecimentos dos quais se dispõe em um momento determinado. Diz-se que a conclusão é plausível. Esse tipo de inferência é denominada derrotável (defeasible) pois ela pode falhar se novas evidências surgirem. Apesar de menos preciso e confiável que os outros dois tipos de argumento, o argumento derrotável é geralmente o mais útil, sendo necessário para condução prática das questões da vida cotidiana.

Novas evidências: Trata-se de novas premissas que podem ser adicionadas sem alterar o valor de verdade das premissas anteriores.

Garantia: Generalização que cumpre função especial dentro da estrutura do argumento, autorizando a inferência.

\begin{tabular}{|l|l|l|}
\hline Tipo / Garantia & \multicolumn{1}{|l|}{ Suporte à Conclusão } & Utilização \\
\hline Dedutivo & Necessidade & Válido ou Inválido \\
\hline Indutivo & Probabilidade (de 0 a 1) & Dados matemáticos ou estatísticos \\
\hline Derrotável & Plausibilidade & Déficit de conhecimento/informação \\
\hline
\end{tabular}

Seção I.1.C - Ônus da Prova, Tipos de Premissas, Status das Premissas, Standards de Prova e Meios de Prova

Ônus da prova: Dever atribuído a uma das partes no diálogo de provar ou sustentar uma determinada premissa em debate, sob pena dela não ser tida como verdadeira. 
Premissas ordinárias: São aquelas que dependem de provas adicionais para serem consideradas verdadeiras. Para serem tornadas falsas também necessitarão de evidências em contrário, não bastando o mero questionamento.

Suposições: Premissas que se assumem como verdadeiras até o momento em que elas são questionadas. Após serem questionadas, serão tornadas falsas ou neutras e dependerão de provas adicionais para serem aceitas como verdadeiras.

Exceções: Premissas que se assumem como falsas até o momento em que se fazem provas em sentido contrário. O questionamento da exceção é incapaz de alterar o seu valor de verdade.

Presunções relativas: Premissas que se assumem como verdadeiras até o momento em que se fazem provas em sentido contrário.

Presunções absolutas: Premissas que se assumem como verdadeiras, independentemente de questionamento ou provas em sentido contrário.

Status da premissa: Avaliação da premissa em verdadeira, falsa ou neutra, em determinado momento do diálogo.

Status prima facie: Status da premissa quando enunciada, dado de acordo com o seu tipo (ordinária, suposição, exceção, presunção relativa ou presunção absoluta).

\begin{tabular}{|c|c|c|c|c|}
\hline Tipo & Prima Facie & Prova (+) & Questionamento & Prova (-) \\
\hline Ordinária & Neutra & Verdadeira & Neutra & Falsa \\
\hline Suposição & Verdadeira & Verdadeira & Neutra/Falsa & Falsa \\
\hline Exceção & Falsa & Verdadeira & Falsa & Falsa \\
\hline Presunção Relativa & Verdadeira & Verdadeira & Verdadeira & Falsa \\
\hline Presunção Absoluta & Verdadeira & Verdadeira & Verdadeira & Verdadeira \\
\hline
\end{tabular}


Ponto de Vista do Analista: Ponto de vista de um terceiro que observa o diálogo imparcialmente e se pauta pelo melhor uso possível da teoria da argumentação e das regras da argumentação.

Standard de prova: Força argumentativa necessária para que uma premissa seja considerada provada.

Meios de prova: Modos pelos quais alguém pode provar alguma coisa. Por exemplo, testemunhas, documentos, fotografias, vídeos, certidões, etc.

\section{Seção I.1.D - Ataques}

Ataque: Denominação dada aos meios que uma parte no diálogo dispõe para combater a argumentação de outra parte.

Réplica (rebuttal): Quando um argumento é oposto a um argumento anterior, temos uma réplica.

Refutação (refutation) Quando a réplica obtém sucesso e derruba (knock down) o argumento original, temos uma refutação.

Implicação pragmática: Característica de uma afirmação feita sobre o mundo real e concreto. $\mathrm{O}$ argumento que possui implicação pragmática diz mais do que o mero condicional "Se..., então ...".

Classificação dos ataques quanto à localização na estrutura do argumento: De acordo com essa classificação, os ataques podem ser de três tipos:

(a) às premissas;

(b) ao link inferencial; e

(c) à conclusão 
Classificação dos ataques quanto ao funcionamento do argumento: De acordo com essa classificação, os ataques podem ser de cinco tipos básicos:

Argumento contrário: Argumento cuja conclusão é oposta à proposição que se quer atacar, seja ela uma premissa ou uma conclusão.

Exceção: Adição de uma nova premissa que sem alterar o valor de verdade (status) das premissas anteriores retira o suporte da conclusão. Não se deve confundir a exceção como ataque com a exceção como tipo de premissa quanto ao ônus da prova. São coisas diferentes, apesar das premissas adicionadas pelas exceções como ataques geralmente ter o seu ônus da prova do tipo exceção.

Ônus da prova e Standard de Prova: Ataques que se baseiam em dizer que o argumento não cumpre com seu ônus probatório.

Questionamento: Ato puro e simples de questionar a veracidade de uma premissa.

Incompletude Ataque que expõe que um argumento é incompleto, e, por isso, as conclusões não se seguem das premissas. Às vezes ao se dizer que um argumento é incompleto pode ser atribuída uma premissa à outra parte no diálogo, para então ser construído um argumento oposto. A atribuição dessa premissa pode ser objeto de debate (problema da atribuição) e não necessariamente precisa ser realizada.

\begin{tabular}{|l|l|l|l|l|}
\hline \multirow{4}{*}{ Estrutura } & Funcionamento & Dedutivo & Indutivo & Derrotável \\
\hline \multirow{4}{*}{ Premissas } & Argumento contrário & Sim & Sim & Sim \\
\cline { 2 - 5 } & Onus da Prova & Sim & Sim & Sim \\
\cline { 2 - 5 } \begin{tabular}{l} 
Linferencial \\
\cline { 2 - 5 }
\end{tabular} & Questionamento & Sim & Sim & Sim \\
\cline { 2 - 6 } & Exceção & Sim & Sim & Sim \\
\hline \multirow{3}{*}{ Conclusão } & Argumento contrário & Não & Sim & Sim \\
\cline { 2 - 6 } & Onus da Prova & Não & Sim & Sim \\
\cline { 2 - 6 } & Questionamento & Não & Sim & Sim \\
\hline
\end{tabular}




\section{I.1.E Estágios do Diálogo e Tipos de Diálogo}

Disputa (dispute): Quando um dos participantes possui uma tese contrária a do outro.

Dissenso (dissent): Quando um dos participantes apenas duvida da tese do outro sem defender uma tese contrária.

Desacordo fático ou de fato: Desacordo quanto a fatos.

Desacordo normativo ou de direito: Desacordo sobre a avaliação de uma conduta (incluindo uma omissão) diante de um quadro normativo ou das próprias normas.

Estágios do Diálogo: Momentos ideais/didáticos de desenvolvimento do diálogo:

Confrontação (confrontation) - Formula-se a tese de uma das partes e a natureza da oposição da outra parte (disputa ou dissenso). A questão a ser resolvida pelo diálogo é determinada por ambas as partes.

Abertura (opening) - As partes decidem começar a discussão e seguir as regras apropriadas ao tipo de diálogo estabelecido.

Argumentação (argumentation) - Cada parte defende seu ponto de vista e questiona e critica o ponto de vista da outra parte.

Fechamento (closing) - A discussão termina e se uma das partes atingiu seu objetivo a outra deve aceitar o resultado (the other side must concede).

\section{Persuasão Racional (rational persuasion) ou Argumentação racional (rational argument): Argumentação na qual (a) o proponente (proponent) tenta fazer $\mathrm{o}$ respondente (respondent) aceitar a conclusão utilizando premissas que o respondente já aceitou ou pode ser persuadido a aceitar usando outros argumentos; (b) o argumento utilizado é estruturalmente correto seja como uma inferência dedutiva, indutiva ou derrotável.}


Tipos Básicos de Diálogo: Conforme classificação dos quadros abaixo.

\begin{tabular}{|c|c|c|c|}
\hline Tipo de Diálogo & Questão/Problema & Funcionamento & Tendência \\
\hline Persuasão & Melhor resposta & Argumentação racional & $\begin{array}{l}\text { Parte } \\
\text { colaborativo e } \\
\text { parte adversarial }\end{array}$ \\
\hline$\underline{\text { Negociação }}$ & Conflito de interesses & $\begin{array}{l}\text { Busca de acordo, envolvendo } \\
\text { ganhos e perdas para as partes }\end{array}$ & $\begin{array}{l}\text { Parte } \\
\text { colaborativo e } \\
\text { parte adversarial }\end{array}$ \\
\hline $\begin{array}{l}\text { Busca } \\
\text { Informacões }\end{array}$ & $\begin{array}{l}\text { Falta/Assimetria de } \\
\text { informação }\end{array}$ & $\begin{array}{l}\text { Perguntas e respostas buscando } \\
\text { compartilhamento de } \\
\text { informação }\end{array}$ & Colaborativo \\
\hline Erístico & $\begin{array}{l}\text { Antagonismo } \\
\text { emocional }\end{array}$ & $\begin{array}{l}\text { Discussão (quarrel), argumento } \\
\text { ad hominem e alívio de } \\
\text { sentimentos }\end{array}$ & Adversarial \\
\hline
\end{tabular}

\begin{tabular}{|l|l|}
\hline Tipo de Diálogo & Principais Subtipos \\
\hline$\underline{\text { Persuasão }}$ & Discussão Crítica, Investigação, Deliberação \\
\hline$\underline{\text { Negociacão }}$ & Barganha Distributiva \\
\hline Busca de Informaç̃es & Diálogo com Expert \\
\hline$\underline{\text { Erístico }}$ & - \\
\hline
\end{tabular}

\section{I.1.F Relevância}

Relevância Probatória (probative relevance): Um argumento ou proposição possui relevância probatória caso sirva para dar suporte ou atacar em última instância a tese controvertida no diálogo. Proposições podem ser julgadas relevantes em relação ao diálogo e premissas podem ser julgadas relevantes em relação ao argumento.

Relevância tópica (topical relevance): Ocorre na hipótese de duas proposições ou dois argumentos tratarem do mesmo assunto.

Relevância emocional ou psicológica (emotional/psychological relevance): Diz respeito à importância subjetiva (para alguém) de uma proposição ou argumento. 
Relevância dialética (dialectical relevance): Se refere ao fato de uma proposição ou argumento ser apropriado ou não como parte de um diálogo de determinado tipo, possuindo (a relevância) caráter normativo.

Esquema Argumentativo: Conjunto dos tipos de argumento/esquemas do argumento aceitos dentro de um diálogo.

Método para verificação da relevância probatória: $O$ método serve para verificar a relevância probatória de uma proposição ou de um argumento e compreende os seguintes passos de verificação:

(1) Tipo de diálogo

(2) Estágio do diálogo

(3) Esquema argumentativo do diálogo

(4) Contexto institucional e prático do diálogo

a. Regras procedimentais

b. Limitações práticas para obtenção de informação, decisão ou ação

\section{Seção I.2 - Ferramentas Básicas}

\section{Seção I.2.A - Esquemas do Argumento}

Esquemas do Argumento: Estrutura inferencial pela qual um argumento opera. Cada esquema do argumento representa um tipo de argumento utilizado na prática argumentativa. Eles podem representar argumentos dedutivos, indutivos ou derrotáveis, sendo especialmente úteis para representação dos últimos. Os esquemas também servem para representar argumentos peculiares a contextos discursivos específicos, como a argumentação jurídica ou a argumentação científica. Os esquemas do argumento são compostos pelas premissas e pela conclusão específicas que o tipo de argumento requer, bem como pelas questões críticas.

Questões críticas (critical questions): Perguntas que se devem fazer a fim de avaliar a pertinência e o suporte à conclusão do argumento no caso concreto. 
Argumento pragmático ou argumento a partir das consequências (argument from consequences): Tipo de argumento que atribui valor a alguma coisa em virtude das consequências que ela gera.

Seção I.2.A.i Refinamento dos Esquemas

Refinamento dos esquemas (schemes refining): Discussão sobre como modelar e apresentar os esquemas do argumento da melhor maneira possível de modo a maximizar a sua utilidade para identificar, analisar, avaliar e criar argumentos. $\mathrm{O}$ refinamento pode seguir o roteiro abaixo:

(1) Tipo de Argumento e Garantia - A fim de identificar o tipo de argumento (dedutivo, indutivo, derrotável) deve ser identificada e incluída a premissa que funciona como garantia e destacado se ela é uma generalização dedutiva, indutiva ou derrotável

(2) Proposições - As proposições que formarão as premissas ou questões críticas devem ser divididas tantas vezes quanto puderem ser objeto de discussões separadas.

(3) Classificação das Proposições (Ônus da Prova) - Cada proposição deve ser classificada conforme o ônus da prova a ela associado (ordinária, suposição, exceção, presunção relativa, presunção absoluta), observando-se o seguinte:

a. Efeitos produzidos na alocação de ônus da prova em um diálogo real;

b. Área do conhecimento para qual o esquema do argumento está sendo construído.

(4) Premissas e Questões Críticas - As proposições ordinárias devem ser modeladas como premissas e as demais como questões críticas.

(5) Questões Críticas Adicionais - Estabeleça uma questão crítica para cada premissa e para a conclusão.

(6) Revisão das Questões Críticas - Reveja as questões críticas, observando o seguinte: 
a. Para as questões críticas dirigidas diretamente às premissas e à conclusão, faça referência a cada tipo de generalização ou afirmação possível.

b. Quando for o caso, faça referência a outros esquemas do argumento para discussões mais detalhadas.

Argumento a partir da opinião do expert (argument from expert opinion): Tipo de argumento que atribui o valor do expert à tese/proposição que ele sustenta.

\section{I.2.A.ii Classificação dos Esquemas}

Classificação dos esquemas (schemes classification): Discussão sobre como determinar qual é o conjunto de esquemas de argumento e organizá-lo. A classificação tem por objetivo ajudar o analista a procurar o esquema do argumento aplicável ao caso com o qual estiver lidando, a partir de uma primeira compreensão das linhas gerais da estrutura do argumento. Em última instância, a classificação ajuda a cumprir os objetivos da teoria da argumentação, ou seja, a identificar, analisar, avaliar e criar argumentos.

\section{Seção I.2.B - Reconstrução dos Argumentos}

Reconstrução dos Argumentos (reconstruction): Discussão sobre como criar uma representação do diálogo real com a qual podemos trabalhar de maneira adequada, utilizando as demais ferramentas da teoria da argumentação. Como toda representação, o processo de reconstrução seleciona e destaca determinados aspectos dos diálogos reais em detrimento de outros. O critério básico que orienta essa reconstrução é a finalidade de resolver a questão dada, de acordo com os parâmetros estabelecidos pela teoria da argumentação.

Elementos da Reconstrução: Elementos importantes a serem extraídos do diálogo real e tornados claros pelo processo de reconstrução:

(1) Questão e Tese - a(s) questão(ões) em debate e a(s) tese(s) sobre ela(s);

(2) Pontos de Vista - as posições dos participantes do diálogo em relação às questões; 
(3) Argumentos, Premissas e Conclusões - os argumentos, premissas e conclusões sejam explícitos ou implícitos que as partes utilizam para sustentar seu ponto de vista;

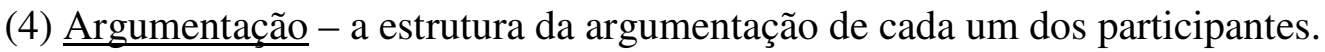

Operações de Transformação: Quatro operações básicas empreendidas pelo analista no processo de reconstrução:

(A) Subtração (deletion) - Tem por objetivo remover toda informação redundante ou irrelevante para fins de construção dos argumentos e resolução da questão dada.

(B) Adição (addition) - Tem por objetivo tornar explícitas as informações implícitas e preencher os passos faltantes no diálogo, de modo a contribuir para a resolução da questão dada. Pode se dar, por exemplo, por meio da adição de questões, premissas ou conclusões.

(C) Permutação (permutation) - Tem por objetivo reordenar os elementos de maneira a tornar a busca pela resolução da questão dada o mais clara possível. Não há necessidade de seguir o tempo real em que os argumentos e elocuções se sucederam. Como exemplo de aplicação, os elementos podem ser reordenados de acordo com os estágios do diálogo.

(D) Substituição (substitution) - Tem por objetivo melhorar a apresentação dos elementos do diálogo de maneira a torná-los os mais claros e precisos possíveis. De um lado, busca garantir a uniformidade da notação dos argumentos. Por exemplo, várias formulações diferentes de um mesmo argumento serão transformadas em uma só. Elementos que apresentam a mesma função serão apresentados da mesma maneira. Por exemplo, uma pergunta retórica que funciona como um argumento será representada como um argumento. De outro lado, formulações vagas e ambíguas serão substituídas por formulações precisas e bem definidas.

Critérios de reconstrução: Critérios gerais que ajudam a circunscrever os limites das transformações a serem realizadas pelo analista. 
Eficácia (efficacy) - Exige que toda transformação leve sem dúvidas a uma formulação que possa ser representada no modelo ideal e sobre a qual podem ser aplicadas as outras ferramentas da teoria da argumentação.

Bom-embasamento (well foundedness) - Requer toda transformação seja baseada em um elemento empírico do discurso e que sirva para contribuir para a resolução da questão dada.

Parcimônia (parsimony) - Demanda que as transformações sejam as mínimas necessárias para tornar o diálogo uma discussão crítica, ou seja, apto a buscar a resolução argumentativa da questão dada.

Nível de detalhes e nível de explicitação - Uma reconstrução concreta pode representar o diálogo em diversos graus de detalhamento e em diversos graus de explicitação (adição de premissas).

Propósito e Posição do analista - O analista é parte importante do processo de reconstrução. Sua posição e seus propósitos específicos e concretos podem servir de critério para orientar o processo de reconstrução.

\section{Seção I.2.C - Diagramação dos Argumentos}

Diagramação do diálogo (diagramming): Discussão sobre como representar o diálogo de uma forma que facilite a visualização pelo analista daquilo que interessa à argumentação, como em uma radiografia. Uma boa visualização ajuda o analista a tomar pé do conteúdo e estado do diálogo, dos seus principais pontos de conflito e dos argumentos fortes e fracos.

Classificação utilizada para argumentos: Conforme esquema a seguir.

Quanto à quantidade de premissas

Argumento de Premissa Única - Contém apenas uma premissa explícita.

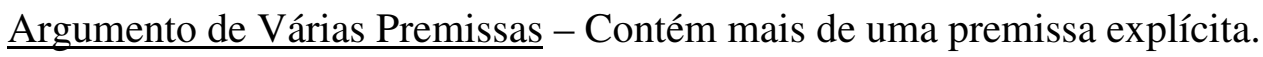


Quanto à completude

Argumento Completo - Todas as premissas e a conclusão são explícitas.

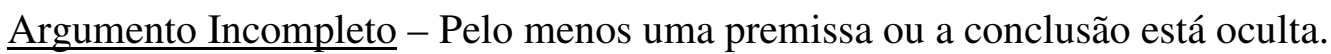

Quanto às premissas - Pelo menos uma premissa está oculta.

Quanto à conclusão - A conclusão está oculta.

Quanto às premissas e à conclusão - Pelo menos uma premissa e a conclusão estão ocultas.

Classificação utilizada para a argumentação: Conforme esquema a seguir.

Quanto à quantidade de argumentos

Argumento Único - Contém apenas um argumento.

Vários Argumentos - Contém mais de um argumento.

Quanto à relação entre os argumentos

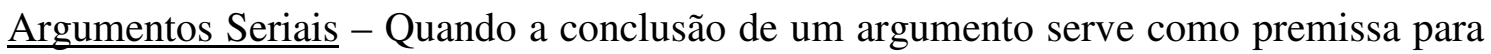
outro argumento diz-se que eles são seriais.

Argumentos Convergentes - Quando dois argumentos sustentam a mesma conclusão diz-se que eles são convergentes.

Argumentos Divergentes - Quando dois argumentos partilham pelo menos uma premissa idêntica, mas sustentam duas conclusões diferentes diz-se que eles são divergentes.

Conceitos básicos para um diagrama: Conforme esquema a seguir.

\section{Premissas/Conclusões}

(A) Enunciante - É fundamental constar no diagrama o responsável por afirmar cada proposição.

(A.1) Premissas Novas e Ocultas - Em especial, deve ser dado destaque às premissas que foram inseridas pelo analista, sejam premissas completamente novas, sejam aquelas advindas de um esforço para identificar a premissa oculta.

(B) Status da Premissa - Para que o diagrama identifique o estado do diálogo, cada premissa/conclusão deve ter seu status (verdadeira, falsa, neutra) identificado. 
(C) Tipo de Premissa (ônus da prova) - Para a visualização do ônus da prova associado é importante classificar o tipo da premissa em ordinária, exceção, suposição, presunção relativa ou presunção absoluta.

(D) Standard de Prova - Ainda para a visualização do ônus da prova associado é importante identificar o standard de prova associado a cada premissa/conclusão.

(E) Suporte Premissas/Conclusão - Para verificar se o ônus da prova foi satisfeito e como, deve ser identificado o suporte dado pelas premissas à cada conclusão, destacando-se se a relação é de necessidade, probabilidade ou plausibilidade.

(B.1) Probabilidade - Para os casos de probabilidade, vale quantificá-la.

(B.2) Plausibilidade - Para os casos de plausibilidade, também vale identificar o grau de força, quando possível.

(B.3) Suficiência/Parcialidade - Para qualquer dos casos, vale identificar se a força do argumento é suficiente para sustentar a conclusão, dado o standard de prova requerido, ou se o suporte é apenas parcial.

\section{Argumentos}

(A) Esquema do Argumento / Tipo de Argumento - Identificar o esquema/tipo do argumento. Por exemplo, argumento pragmático ou argumento baseado na opinião do expert. Usando essa informação o analista pode pensar ou buscar rapidamente os ataques possíveis ao argumento.

(B) Tipo de Argumento (inferência) - Identificar o tipo de argumento; se é dedutivo, indutivo ou derrotável. É o equivalente a identificar o suporte das premissas à conclusão; se é por necessidade, probabilidade ou verossimilhança. O Esquema do Argumento / Tipo de Argumento também já fornece essa informação.

(C) Suporte à Conclusão - Equivalente ao item (E) da lista sobre Premissas/Conclusões.

Níveis de apresentação do diagrama de um diálogo: Há três possibilidades, conforme o grau de detalhamento. O nível das proposições é o mais detalhado, o dos argumentos é intermediário e das questões é o menos detalhado.

Nível das proposições - Os elementos básicos do diagrama são premissas e conclusões.

Nível da argumentação - Os elementos básicos do diagrama são os argumentos.

Nível do problema - Os elementos básicos a serem apresentados são as questões. 


\section{APÊNDICE II \\ MAPA CONCEITUAL - CAPÍTULO II}

\section{Seção II.1 - Algumas características da argumentação jurídica}

(i) Questões de fato x Questões de Direito

(ii) Regras e Exceções

(iii) Contexto e Objetivos

(iv) Condições e Consequências

(v) A Melhor Resposta

\section{Seção II.2 - Esquemas de Argumentos no Direito}

Argumentos de justificação: Os argumentos de justificação são os meios pelos quais se constrói e se atribui valor, positivo ou negativo, a uma tese ou alternativa.

(i) Argumento sobre a tradição: atribui valor a uma tese ou fato A em virtude de A ser essencialmente semelhante a uma tese ou fato B, o qual já possui valor reconhecido.

(ii) Argumento a partir da posição de saber: Atribui a uma tese ou fato o valor, ou parte do valor, da pessoa, grupo ou instituição que defende essa tese ou fato e que também constituiria quem está em melhor posição de saber sobre o assunto.

(iii) Argumento pragmático: Atribui à uma tese ou fato o valor, ou parte do valor, de suas consequências. 
Argumentos de operacionalização: Servem à discussão da aplicabilidade concreta dos argumentos de justificação, fazendo com que a construção e atribuição de valor possa ser operada na prática. Argumentos que visem a estabelecer uma relação de semelhança ou dessemelhança entre dois casos, e argumentos que discutam a relação de causalidade entre dois fatos são exemplos do tipo de argumento que se encontrará dentre os argumentos de operacionalização.

\section{Classificação dos Esquemas:}

\section{$\rightarrow \underline{\text { Argumentos de Justificacão }}$}

- Tradição

- Tradição Jurídica

- Aplicação de Norma Jurídica

- Posição de Saber

- Opinião do Expert

- Pragmático

- Objetivo da Lei

\section{$\rightarrow$ Argumentos de Operacionalizacão}

- Exceção Jurídica (operacionalização de condições)

\section{$\underline{\text { Argumento de Tradicão }}$}

\section{Argumento de Tradicão}

\begin{tabular}{|l|l|}
$\begin{array}{l}\text { Premissa 1 } \\
\text { (Garantia) }\end{array}$ & $\begin{array}{l}\text { Sempre que A for essencialmente semelhante a B e B tiver sido } \\
\text { decidido juridicamente de maneira correta, então A deverá ser decidido } \\
\text { do mesmo modo que B. (generalização absoluta) }\end{array}$ \\
\hline $\begin{array}{l}\text { Premissa 2 } \\
\text { (Decisão B) }\end{array}$ & B foi juridicamente decidido de modo X. (ordinária) \\
\hline $\begin{array}{l}\text { Premissa 3 } \\
\text { (Semelhança) }\end{array}$ & A é essencialmente semelhante a B. (ordinária) \\
\hline Conclusão & A deve ser juridicamente decidido de modo X. \\
\hline
\end{tabular}




\section{Questões Críticas}

\begin{tabular}{|l|l|}
\hline $\begin{array}{l}\text { Questão 1 } \\
\text { (Correção de }\end{array}$ & $\begin{array}{l}\text { X foi a decisão correta para B? Ou B deveria ter sido decidido de modo } \\
\text { X) }\end{array}$ \\
\hline Questão 2 & B foi realmente decidido juridicamente do modo X? \\
\hline $\begin{array}{l}\text { Questão 3 } \\
\text { (Semelhança) }\end{array}$ & $\begin{array}{l}\text { A é realmente essencialmente semelhante a B? } \\
(\text { ver esquemas do argumento de operacionalização sobre } \\
\text { semelhança/dessemelhança) }\end{array}$ \\
\hline
\end{tabular}

\section{Argumento para Aplicacão de Normas Jurídicas}

\section{Argumento para Aplicação de Normas Jurídicas}

\begin{tabular}{l|l} 
Premissa 1 & Geralmente se há uma norma jurídica válida e vigente $\mathrm{N}$ que estabelece
\end{tabular} (Garantia) que se A então X, e A é o caso, então devem ser as consequências

\begin{tabular}{|l|l|} 
& jurídicas X. (generalização derrotável) \\
\hline Premissa 2 & $\begin{array}{l}\text { A norma jurídica N estabelece que se A, então devem ser as } \\
\text { consequências jurídicas X. }\end{array}$ \\
\hline Premissa 3 & É o caso de A. \\
\hline Conclusão & Devem ser as consequências jurídicas X. \\
\hline
\end{tabular}

\begin{tabular}{|l|l|}
\hline Questões Críticas \\
\hline Questão 1 & $\begin{array}{l}\text { Como foi construída a norma N? (problema de interpretação) } \\
\text { (suposição) }\end{array}$ \\
\hline Questão 2 & A norma jurídica N é válida? (exceção) \\
\hline Questão 3 & A norma jurídica N é vigente? (exceção) \\
\hline Questão 4 & \begin{tabular}{l} 
Há exceções à norma jurídica N (condições para que Não-X)? Há no \\
caso concreto outras condições necessárias, suficientes ou contributivas \\
de X? Como classificar a(s) condição(ões) presentes em A (necessária, \\
suficiente ou contributiva)? \\
\hline Questão 5
\end{tabular} \\
\hline
\end{tabular}




\section{$\underline{\text { Argumento a partir da posicão de saber }}$}

\begin{tabular}{|c|c|}
\hline \multicolumn{2}{|c|}{ Argumento a partir da posição de saber } \\
\hline $\begin{array}{l}\text { Premissa } 1 \\
\text { (Garantia) }\end{array}$ & $\begin{array}{l}\text { Geralmente se uma fonte } a \text { está em posição de saber em um domínio S } \\
\text { que contém a proposição A, e } a \text { enuncia que A é verdadeira (falsa), } \\
\text { então A é verdadeira (falsa). (generalização derrotável) }\end{array}$ \\
\hline $\begin{array}{l}\text { Premissa } 2 \\
\text { (Posição de } \\
\text { Saber) }\end{array}$ & $\begin{array}{l}\text { A fonte } a \text { está em posição de saber em um domínio } \mathrm{S} \text { que contém a } \\
\text { proposição A. (ordinária) }\end{array}$ \\
\hline $\begin{array}{l}\text { Premissa } 3 \\
(\text { Asserção) }\end{array}$ & $a$ enuncia que a proposição A é verdadeira (falsa). (ordinária) \\
\hline Conclusão & A é verdadeiro (falso). \\
\hline
\end{tabular}

\section{Questões Críticas}

\begin{tabular}{|l|l|}
\hline Questão 1 & $a$ é uma fonte pessoalmente confiável/honesta? ( exceção) \\
\hline Questão 2 & $a$ está realmente em posição de saber se A é verdadeira (falsa)? \\
\hline Questão 3 & $a$ realmente disse que A é verdadeira (falsa)? \\
\hline
\end{tabular}

\section{$\underline{\text { Argumento a partir da opinião do Expert }}$}

\section{Argumento a partir da Opinião do Expert}

\begin{tabular}{|l|l|}
$\begin{array}{l}\text { Premissa 1 } \\
\text { (Garantia) }\end{array}$ & $\begin{array}{l}\text { Geralmente se uma fonte E é um expert na área do conhecimento S, que } \\
\text { contém a proposição A, e E enuncia que A é verdadeira (falsa), então A } \\
\text { é verdadeira (falsa). (generalização derrotável) }\end{array}$ \\
\hline Premissa 2 & $\begin{array}{l}\text { A fonte E é um expert na área do conhecimento S, que contém a } \\
\text { proposição A. }\end{array}$ \\
\hline Premissa 3 & E enuncia que a proposição A é verdadeira (falsa). \\
\hline Conclusão & A é verdadeiro (falso). \\
\hline
\end{tabular}




\section{Questões Críticas}

\begin{tabular}{|l|l|}
\hline Questão 1 & Expertise - Qual é a credibilidade de E como expert? \\
\hline Questão 2 & Campo - E é um expert na área de conhecimento da qual A faz parte? \\
\hline Questão 3 & Opinião - O que E disse que implica A? \\
\hline Questão 4 & Confiança - E é pessoalmente confiável como fonte? \\
\hline Questão 5 & Consistência - A é consistente com o que outros experts dizem? \\
\hline Questão 6 & Evidência de Base - A assertiva de E é baseada em evidências? \\
\hline
\end{tabular}

\section{$\underline{\text { Argumento Pragmático }}$}

\begin{tabular}{|l|l|}
\hline \multicolumn{2}{|l|}{ Argumento Pragmático (Positivo) } \\
$\begin{array}{l}\text { Premissa 1 } \\
\text { (Garantia) }\end{array}$ & $\begin{array}{l}\text { Geralmente se alguma coisa A gera alguma coisa boa X, então A deve } \\
\text { ser realizado. (generalização derrotável) }\end{array}$ \\
\hline $\begin{array}{l}\text { Premissa 2 } \\
\text { (Causal) }\end{array}$ & Se A for realizado, então X (certamente, provavelmente, \\
plausivelmente) ocorrerá. (ordinária)
\end{tabular}

\begin{tabular}{|l|l|}
\hline Questões Críticas \\
\hline Questão 1 & Se A for realizado, X (certamente, provavelmente, plausivelmente) \\
& ocorrerá? \\
• Há certeza? & Quão provável é a ocorrência de X? \\
& $\begin{array}{l}\text { • Quão plausível é a ocorrência de X? } \\
\text { (Ver esquema do argumento da relação causa / consequência) }\end{array}$ \\
\hline Questão 2 & $\begin{array}{l}\text { X é algo bom? } \\
\text { • Sim ou não? } \\
\text { • Quão bom é X? } \\
\text { (Ver esquema do argumento da valoração) }\end{array}$ \\
\hline Questão 3 & $\begin{array}{l}\text { Há outras consequências opostas (más em oposição a boas, por } \\
\text { exemplo) que deveriam ser consideradas? }\end{array}$ \\
\hline
\end{tabular}




\section{Argumento pelo Objetivo da Lei}

\section{Argumento pelo Objetivo da Lei / Intenção do Legislador}

\begin{tabular}{l|l} 
Premissa 1 & Geralmente se a Lei tem por objetivo proteger ou alcançar X e a decisão
\end{tabular}

(Garantia) D protege ou alcança X, então a decisão D deve ser tomada. (generalização derrotável)

\begin{tabular}{|l|l|}
\hline $\begin{array}{l}\text { Premissa 2 } \\
\text { (Objetivo) }\end{array}$ & A Lei tem por objetivo proteger ou alcançar X. (ordinária) \\
\hline $\begin{array}{l}\text { Premissa 3 } \\
\text { (Decisão) }\end{array}$ & A decisão D protege ou alcança X. (ordinária) \\
\hline Conclusão & Deve ser tomada a decisão D. \\
\hline
\end{tabular}

\section{Questões Críticas}

\begin{tabular}{|l|l|}
\hline Questão 1 & A Lei realmente tem por objetivo proteger ou alcançar X? \\
\hline Questão 2 & $\begin{array}{l}\text { A decisão D realmente protege ou alcança X? Em que medida se dá essa } \\
\text { proteção? } \\
\text { (Ver esquema do argumento da relação causa / consequência) } \\
\text { (Ver esquema do argumento da valoração) }\end{array}$ \\
\hline Questão 3 & $\begin{array}{l}\text { Há outros valores ou objetivos Y protegidos pela Lei e afetados } \\
\text { negativamente pela decisão D? } \\
\text { - Em caso positivo, há outra decisão D1 que possa assegurar igual } \\
\text { proteção a X sem afetar negativamente Y? } \\
\text { - Em que medida Y é afetado? } \\
\text { (Ver esquema do argumento da relação causa / consequência) } \\
\text { (Ver esquema do argumento da valoração) }\end{array}$ \\
\hline
\end{tabular}




\section{Excecão (Argumento de Operacionalizacão de Condicões)}

\section{Exceção (Argumento de Operacionalização de Condições)}

\begin{tabular}{|l|l|}
\hline $\begin{array}{l}\text { Premissa 1 } \\
\text { (Condição) }\end{array}$ & $\begin{array}{l}\text { A norma N pressupõe a condição (absoluta, necessária, suficiente, } \\
\text { contributiva) X para a consequência Y. (ordinária) }\end{array}$ \\
\hline $\begin{array}{l}\text { Premissa 2 } \\
\text { (Presença) }\end{array}$ & A condição X está /não está presente no caso. (ordinária) \\
\hline Conclusão & Então (necessariamente, plausivelmente) Y / não-Y. \\
\hline
\end{tabular}

\section{Questões Críticas}

\begin{tabular}{|c|c|}
\hline Questão 1 & A norma $\mathrm{N}$ realmente pressupõe a condição $\mathrm{X}$ para a consequência $\mathrm{Y}$ ? \\
\hline Questão 2 & A condição X realmente está/não está presente no caso? \\
\hline $\begin{array}{l}\text { Observação } \\
\text { conforme o } \\
\text { tipo de } \\
\text { condição }\end{array}$ & $\begin{array}{l}\text { Condicão Absoluta } \\
\text { X: generalização absoluta / conclusão necessária positiva } \\
\text {-X: generalização absoluta / conclusão necessária negativa } \\
\text { Condição Necessária } \\
\text { X: generalização derrotável / conclusão derrotável positiva } \\
\text {-X: generalização absoluta / conclusão necessária negativa } \\
\text { Condição Suficiente } \\
\text { X: generalização absoluta / conclusão necessária positiva } \\
\text {-X: generalização derrotável / conclusão derrotável negativa } \\
\text { Condiccão Contributiva } \\
\text { X: generalização derrotável / conclusão derrotável positiva } \\
\text {-X: generalização derrotável / conclusão derrotável negativa }\end{array}$ \\
\hline
\end{tabular}

Condição necessária: A é uma condição necessária quando sem ela $X$ não pode existir.

Condição suficiente: A é uma condição suficiente quando basta A para que X exista. 
Condição contributiva: A é uma condição contributiva quando ela não é necessária nem suficiente, mas, conjuntamente com outras condições, contribui para que $\mathrm{X}$ exista.

\begin{tabular}{|l|l|l|l|}
\hline Necessária & Suficiente & Contributiva & Observação \\
\hline Sim & Sim & Não & Unica e absoluta \\
\hline Sim & Não & Não & Necessária \\
\hline Não & Sim & Não & Suficiente \\
\hline Não & Não & Sim & Contributiva \\
\hline Não & Não & Não & Irrelevante \\
\hline
\end{tabular}




\section{APÊNDICE III MATERIAL DE PESQUISA}

\section{Relatórios e Dossiês}

ARQUIDIOCESE DE SÃO PAULO. Brasil: Nunca Mais. 39ª Ed. Petrópolis: Vozes, 2011.

ARQUIDIOCESE DE SÃO PAULO. Brasil: Nunca Mais - Projeto “A”. 1985. Disponível em www.armazemmemoria.com.br. Último acesso em 12 de dezembro de 2012.

BRASIL. Ministério da Justiça. Comissão de Anistia. Relatório Anual da Comissão de Anistia 2010. Brasília: Comissão de Anistia, 2010.

BRASIL. Secretaria Especial dos Direitos Humanos. Comissão Especial sobre Mortos e Desaparecidos Políticos. Direito à Verdade e à Memória. Brasília: Secretaria Especial de Direitos Humanos, 2007.

COMISSÃO DE FAMILIARES DE MORTOS E DESPARECIDOS POLÍTICOS. Dossiê Ditadura: mortos e desaparecidos políticos no Brasil (1964-1985). São Paulo: Imprensa Oficial, $2^{\text {a }}$ Ed., 2009.

\section{$\underline{\text { Notícias }}$}

\section{Em ordem cronológica}

1979

VEJA. Anistia? Só restrita... Edição 554, 18 de abril de 1979, p. 20-23. Disponível em http://veja.abril.com.br/acervodigital/. Acesso em 13 de dezembro de 2012.

VEJA. A Anistia de 1979. Edição 564, 27 de junho de 1979. Disponível em http://veja.abril.com.br/acervodigital/. Acesso em 11 de março de 2012.

VEJA. A Festa da anistia. Edição 565, 04 de julho de 1979. Disponível em http://veja.abril.com.br/acervodigital/. Acesso em 11 de março de 2012.

VEJA. Limites em Discussão. Edição 566, 11 de julho de 1979, p. 25-27. Disponível em http://veja.abril.com.br/acervodigital/. Acesso em 13 de dezembro de 2012.

NUNES, Augusto. Em nome da lei - Entrevista com Octavio Gonzaga Júnior. Veja. Edição 573, 28 de agosto de 1979. Disponível em http://veja.abril.com.br/acervodigital/. Acesso em 01 de fevereiro de 2012.

VEJA. A página virada. Edição 573, 28 de agosto de 1979. Disponível em http://veja.abril.com.br/acervodigital/. Acesso em 01 de fevereiro de 2012. 
FOLHA DE SÃO PAULO. Edição de 29 de agosto de 1979. Folha de São Paulo. Disponível em http://acervo.folha.com.br. Acesso em 01 de fevereiro de 2012.

JORNAL DO BRASIL. Figueiredo sanciona Lei da Anistia com o $n^{o}$ 6.683. Jornal do Brasil (p.4). 29 de agosto de 1979. Disponível em http://news.google.com/newspapers?nid=0qX8s2k1IRwC. Acesso em 12 de março de 2012.

JORNAL DO BRASIL. Satyro reclama excesso de cautela. Jornal do Brasil (p.4). 29 de agosto de 1979. Disponível em http://news.google.com/newspapers?nid=0qX8s2k1IRwC. Acesso em 12 de março de 2012.

JORNAL DO BRASIL. Veto causa dúvidas no Congresso. Jornal do Brasil (p.4). 29 de agosto de 1979. Disponível em http://news.google.com/newspapers?nid=0qX8s2k1IRwC. Acesso em 12 de março de 2012.

FOLHA DE SÃO PAULO. Edição de 30 de agosto de 1979. Folha de São Paulo. Disponível em http://acervo.folha.com.br. Acesso em 01 de fevereiro de 2012.

FOLHA DE SÃO PAULO. Edição de 31 de agosto de 1979. Folha de São Paulo. Disponível em http://acervo.folha.com.br. Acesso em 01 de fevereiro de 2012.

VEJA. Nas asas da anistia. Veja. Edição 574, 05 de setembro de 1979. Disponível em http://veja.abril.com.br/acervodigital/. Acesso em 01 de fevereiro de 2012.

VEJA. Volta à superfície. Veja. Edição 574, 05 de setembro de 1979. Disponível em http://veja.abril.com.br/acervodigital/. Acesso em 01 de fevereiro de 2012.

\section{4}

FOLHA DE SÃO PAULO. Cinco anos depois da anistia, excluídos lutam por seus direitos (Primeiro Caderno, p.6). Edição de 29 de agosto de 1984. Folha de São Paulo. Disponível em http://acervo.folha.com.br. Acesso em 10 de março de 2012.

\section{5}

VEJA. A Constelação da Crise. Edição 895, 30 de outubro de 1985, p. 36-40. Disponível em http://veja.abril.com.br/acervodigital/. Acesso em 01 de fevereiro de 2012.

FOLHA DE SÃO PAULO. Congresso promulga emenda que convoca constituinte. Edição de 28 de novembro de 1985. (Primeiro Caderno, p.9) Disponível em http://acervo.folha.com.br. Acesso em 13 de dezembro de 2012. 
STYCER, Maurício. Famílias fazem apelo sobre "desaparecidos”. Folha de São Paulo. $1^{\circ}$ de junho de 1994. Primeiro Caderno, p.6. Disponível em http://acervo.folha.com.br. Acesso em 13 de março de 2012.

FOLHA DE SÃO PAULO. Arquivo do DOPS é aberto para consulta. Edição de 25 de agosto de 1994. (Caderno Brasil, p.4) Disponível em http://acervo.folha.com.br. Acesso em 13 de março de 2012.

\section{5}

SOUZA, Carlos Alberto de. Dirigente mundial da Anistia critica FHC. Folha de São Paulo. 12 de abril de 1995. Primeiro Caderno, p. 11. Disponível em http://acervo.folha.com.br. Acesso em 13 de dezembro de 2012.

FOlHA DE SÃO PAULO. Porta-Voz nega que Planalto tenha recuado. Folha de São Paulo. 29 de junho de 1995. Primeiro Caderno, p. 12. Disponível em http://acervo.folha.com.br. Acesso em 14 de março de 2012.

FOLHA DE SÃO PAULO. Projeto não extrapola anistia, diz Presidente. Folha de São Paulo. 19 de agosto de 1995. Primeiro Caderno, p. 9. Disponível em http://acervo.folha.com.br. Acesso em 14 de março de 2012.

FOLHA DE SÃO PAULO. Razões humanitárias não permitem violação à Lei de Anistia, diz Jobim. Folha de São Paulo. 22 de agosto de 1995. Primeiro Caderno, p. 14. Disponível em http://acervo.folha.com.br. Acesso em 14 de março de 2012.

FOLHA DE SÃO PAULO. Governo enviará projeto no dia 28. Folha de São Paulo. 23 de agosto de 1995. Primeiro Caderno, p. 11. Disponível em http://acervo.folha.com.br. Acesso em 14 de março de 2012.

GONDIM, Abnor. Ex-militares punidos em 64 pedem compensações. Folha de São Paulo. 23 de agosto de 1995. Primeiro Caderno, p. 11. Disponível em http://acervo.folha.com.br. Acesso em 14 de março de 2012.

NERI, Emanuel General se opõe a projeto e deixa comando. Folha de São Paulo. 23 de agosto de 1995. Primeiro Caderno, p. 11. Disponível em http://acervo.folha.com.br. Acesso em 14 de março de 2012.

NOGUEIRA, Rui. Maior oposição vem da reserva. Folha de São Paulo. 23 de agosto de 1995. Primeiro Caderno, p. 11. Disponível em http://acervo.folha.com.br. Acesso em 14 de março de 2012.

FOLHA DE SÃO PAULO. Entidade defende punição. Folha de São Paulo. 26 de agosto de 1995. Primeiro Caderno, p. 4. Disponível em http://acervo.folha.com.br. Acesso em 14 de março de 2012. 
PINTO, Paulo Silva; NOGUEIRA, Rui. Aeronáutica apóia projeto para pagar indenizações. Folha de São Paulo. 26 de agosto de 1995. Primeiro Caderno, p. 4. Disponível em http://acervo.folha.com.br. Acesso em 14 de março de 2012.

FOLHA DE SÃO PAULO. FHC vai vetar investigações sobre mortes. Edição de 29 de agosto de 1995. Primeiro Caderno, p.8. Folha de São Paulo. Disponível em http://acervo.folha.com.br. Acesso em 14 de março de 2012.

Obs: Linha do tempo das tensões políticas envolvendo a edição de Lei de Mortos e Desaparecidos.

FOLHA DE SÃO PAULO. Familiares não pedem punição. Edição de 29 de agosto de 1995. Primeiro Caderno, p.8. Folha de São Paulo. Disponível em http://acervo.folha.com.br. Acesso em 14 de março de 2012.

FOLHA DE SÃO PAULO. É capenga, diz Marighella $F^{o}$. Folha de São Paulo. 30 de agosto de 1995. Primeiro Caderno, p. 11. Disponível em http://acervo.folha.com.br. Acesso em 14 de março de 2012.

FOlHA DE SÃO PAULO. Projeto é corajoso, diz Eunice. Folha de São Paulo. 30 de agosto de 1995. Primeiro Caderno, p. 11. Disponível em http://acervo.folha.com.br. Acesso em 14 de março de 2012.

NERI, Emanuel; GONDIM, Abnor. Familiares acusam governo de manobra. Folha de São Paulo. 30 de agosto de 1995. Primeiro Caderno, p. 11. Disponível em http://acervo.folha.com.br. Acesso em 14 de março de 2012.

SANTIAGO, Vandeck. Anistiado pede 'esquecimento'. Folha de São Paulo. 30 de agosto de 1995. Primeiro Caderno, p. 11. Disponível em http://acervo.folha.com.br. Acesso em 14 de março de 2012.

FOLHA DE SÃO PAULO. Militar acusado de tortura volta ao Brasil e deve chegar a Brasília hoje. Folha de São Paulo. 3 de setembro de 1995. Primeiro Caderno, p. 8. Disponível em http://acervo.folha.com.br. Acesso em 14 de março de 2012.

MENEZES, Cynara; SECCO, Alexandre. Gregori aprova indenizar 111 do Carandiru. Folha de São Paulo. 3 de setembro de 1995. Primeiro Caderno, p. 8. Disponível em http://acervo.folha.com.br. Acesso em 14 de março de 2012.

FRANÇA, William. Anistia se sobrepõe a dor das famílias, diz general. Folha de São Paulo. 4 de setembro de 1995. Primeiro Caderno, p.4. Disponível em http://acervo.folha.com.br. Acesso em 14 de março de 2012.

BICUDO, Hélio. Lei de Anistia e Crimes Conexos. Folha de São Paulo, 06 de dezembro de 1995. Disponível em http://acervo.folha.com.br. Acesso em 18 de fevereiro de 2012. 


\section{6}

FOLHA DE SÃO PAULO. Exército sonegou ao governo informações sobre guerrilha (Primeiro Caderno, p.12). Edição de 30 de abril de 1996. Folha de São Paulo. Disponível em http://acervo.folha.com.br. Acesso em 10 de março de 2012.

FOLHA DE SÃO PAULO. Médico cassado por participar de torturas recupera o registro (Primeiro Caderno, p.12). Edição de 30 de abril de 1996. Folha de São Paulo. Disponível em http://acervo.folha.com.br. Acesso em 10 de março de 2012.

CIPOLA, Ari. Comissão investiga dezenove cemitérios. Folha de São Paulo. 7 de maio de 1996. Primeiro Caderno, p.10. Disponível em http://acervo.folha.com.br. Acesso em 14 de março de 2012.

FOLHA DE SÃO PAULO. Equipe tenta achar corpos. Folha de São Paulo. 26 de junho de 1996. Primeiro Caderno, p.10. Disponível em http://acervo.folha.com.br. Acesso em 14 de março de 2012.

PINTO, Paulo Silva. Mandíbula não é da ossada de Lamarca, conclui novo laudo. Folha de São Paulo. 26 de junho de 1996. Primeiro Caderno, p.10. Disponível em http://acervo.folha.com.br. Acesso em 14 de março de 2012.

FOLHA DE SÃO PAULO. Clube militar critica reparação à famílias. Folha de São Paulo. 25 de julho de 1996. Primeiro Caderno, p.12. Disponível em http://acervo.folha.com.br. Acesso em 14 de março de 2012.

FRANÇA, William. Lamarca estava deitado ao ser atingido. Folha de São Paulo. 25 de julho de 1996. Primeiro Caderno, p.8. Disponível em http://acervo.folha.com.br. Acesso em 14 de março de 2012.

FOLHA DE SÃO PAULO. Para deputado, houve execução. Folha de São Paulo. 26 de julho de 1996. Primeiro Caderno, p.8. Disponível em http://acervo.folha.com.br. Acesso em 14 de março de 2012.

FOLHA DE SÃO PAULO. Legistas não identificam ossadas. Folha de São Paulo. 26 de julho de 1996. Primeiro Caderno, p.8. Disponível em http://acervo.folha.com.br. Acesso em 14 de março de 2012.

FRANÇA, William. Laudo diz que tiro de fuzil matou Lamarca. Folha de São Paulo. 26 de julho de 1996. Primeiro Caderno, p.12. Disponível em http://acervo.folha.com.br. Acesso em 14 de março de 2012.

1998

GOMES, Oswaldo Pereira. Os militares e a comissão dos desaparecidos. Folha de São Paulo. 23 de outubro de 1998. Primeiro Caderno, p.3. Disponível em http://acervo.folha.com.br. Acesso em 13 de março de 2012. 
Obs: Artigo do advogado e militar integrante da Comissão de Mortos e Desaparecidos, que criticou a legislação (dando parecer contrário) e votou contra a concessão de indenização nos casos de Marighella, Lamarca e Zuzu Angel.

OLTRAMARI, Alexandre. "Torturei uns trinta". Veja. 09 de dezembro de 1998. Disponível em http://veja.abril.com.br/091298/p_044.html. Acesso em 04 de janeiro de 2012.

OLTRAMARI, Alexandre. Esse maldito passado. Veja. 09 de dezembro de 1998. Disponível em http://veja.abril.com.br/091298/p_050.html. Acesso em 04 de janeiro de 2012.

PETRY, André. Porão Iluminado. Veja. 09 de dezembro de 1998. Disponível em http://veja.abril.com.br/091298/p_042.html. Acesso em 04 de janeiro de 2012.

\section{1}

FOLHA DE SÃO PAULO. Marta autoriza transferência de ossadas. Edição de 10 de maio de 2001. Folha de São Paulo. Primeiro Caderno, p. 13. Disponível em http://acervo.folha.com.br. Acesso em 13 de março de 2012.

FOLHA DE SÃO PAULO. Exército diz que mantém termos da nota anterior. Folha de São Paulo. 19 de agosto de 2001. Primeiro Caderno, p. 14. Disponível em http://acervo.folha.com.br. Acesso em 13 de março de 2012.

SOUZA, Josias de. Exército planejou "cemitério" na selva. Folha de São Paulo. 19 de agosto de 2001. Primeiro Caderno, p. 14. Disponível em http://acervo.folha.com.br. Acesso em 13 de março de 2012.

\section{2}

CAMPOS, Ana Maria. União terá de pagar indenização de $R \$ 6,5$ milhões para desaparecido no regime militar. Superior Tribunal de Justiça (Notícias online). 17 de $\begin{array}{llll}\text { outubro de } & 2002 . & \text { Disponível em }\end{array}$ http://www.stj.gov.br/portal_stj/publicacao/engine.wsp?tmp.area=368\&tmp.texto=70985 . Acesso em 10 de março de 2012.

DANTAS, Iuri. Polícia Federal vai liberar arquivos do regime militar. Folha de São Paulo. 24 de setembro de 2002. Primeiro Caderno, p.5. Disponível em http://acervo.folha.com.br. Acesso em 14 de março de 2012.

FOLHA DE SÃO PAULO. Somente três corpos foram identificados. Folha de São Paulo. 24 de setembro de 2002. Primeiro Caderno, p.5. Disponível em http://acervo.folha.com.br. Acesso em 14 de março de 2012. 
FOLHA DE SÃO PAULO. "Você pode pensar, mas não pode agir”. Folha de São Paulo. 02 de dezembro de 2002. Disponível em http://www1.folha.uol.com.br/folha/brasil/ult96u43044.shtml. Acesso em 04 de janeiro de 2012.

\section{6}

BICUDO, Hélio; PIOVESAN, Flávia. Direito à verdade e à justiça. Folha de São Paulo, 20 de novembro de 2006.2 Disponível em http://www.vermelho.org.br/especiais/noticia.php?id_noticia=10269\&id_secao=1.

SECRETARIA DE DIREITOS HUMANOS. Governo divulga relatório final sobre localização de desaparecidos na Guerrilha do Araguaia. 28 de março de 2007. Disponível em

http://portal.sdh.gov.br/clientes/sedh/sedh/noticias/ultimas_noticias/2007/03/MySQLNotici a.2007-03-28.0542/?searchterm=relat\%C3\%B3rio\%20araguaia. Acesso em 13 de dezembro de 2012.

2008

BÄCHTOLD, Felipe. Estados deram indenizações a 2.272 vítimas da ditadura. Folha de São Paulo. 23 de abril de 2008. Disponível em http://www1.folha.uol.com.br/folha/brasil/ult96u394785.shtml. Acesso em 04 de janeiro de 2012.

Obs: Dados sobre as indenizações federais e estaduais concedidas.

FERRAZ, Lucas. Governo abre debate sobre punição à tortura. Folha de São Paulo. 31 de julho de $2008 . \quad$ Disponível em http://www1.folha.uol.com.br/folha/brasil/ult96u428078.shtml. Acesso em 04 de janeiro de 2012.

GIRALDI, Renata. Planalto quer estimular debate sobre punição a torturadores da ditadura. Folha de São Paulo. 31 de julho de 2008. Disponível em http://www1.folha.uol.com.br/folha/brasil/ult96u428341.shtml. Acesso em 04 de janeiro de 2012.

FERRAZ, Lucas. "Ele não se arrepende”, diz mulher de Ustra. Folha de São Paulo. 13 de agosto de 2008.2 Disponível em http://www1.folha.uol.com.br/folha/brasil/ult96u432843.shtml. Acesso em 04 de janeiro de 2012. 
OLIVEIRA, Luciano. Ecos do Porão: a "guerra suja” mais de 30 anos depois. Postado em 14 de agosto de 2008 Disponível em http://www.revistaalgomais.com.br/noticias/noticiaClicada.php?not=368. Acesso em $18 \mathrm{de}$ fevereiro de 2012.

COMPARATO, Fábio Konder. Crimes sem castigo. Folha de São Paulo. 19 de setembro de 2008. Disponível em http://www.conjur.com.br/2008-set19/nao_foi_estendida_anistia_criminal_aos_carrascos_regime_militar. Acesso em 04 de janeiro de 2012.

MERLINO, Tatiana. Justiça de SP extingue ação contra coronel acusado de tortura. Brasil de Fato. 23 de setembro de 2008. Disponível em http://www.brasildefato.com.br/node/876. Acesso em 04 de janeiro de 2012.

FARAH, Tatiana. Coronel Ustra é declarado torturador pela Justiça. O Globo. 09 de outubro de 2008. Disponível em http://oglobo.globo.com/pais/mat/2008/10/09/sp_coronel_ustra_declarado_torturador_pela justica-548643050.asp (testar link) / http://www2.senado.gov.br/bdsf/bitstream/id/137147/1/noticia.htm. Acesso em 04 de janeiro de 2012.

FLOR, Ana. Desculpa por tortura faria bem a militares, por Glenda Mezarobba. Folha de São Paulo. 10 de novembro de 2008. Disponível em http://www.observatoriodeseguranca.org/imprensa/opinioes/glenda. Acesso em 18 de fevereiro de 2012.

SCINOCCA, Ana Paula. Câmara tentará punir tenente que confessou tortura. O Estado de São Paulo. 06 de dezembro de 2008. Disponível em http://www.estadao.com.br/noticias/impresso,camara-tentara-punir-tenente-que-confessoutortura,289414,0.htm. Acesso em 04 de janeiro de 2012.

2009

CONSULTOR JURÍDICO. Para Jobim, ideia de punir militares é "revanchismo". Consultor Jurídico. 11 de junho de 2009. Disponível em http://www.conjur.com.br/2009jun-11/ideia-punir-militares-ditadura-revanchismo-nelson-jobim. Acesso em 18 de fevereiro de 2012.

CONSULTOR JURÍDICO. OAB responde a Jobim sobre punição de militares. Consultor Jurídico. 11 de junho de 2009. Disponível em http://www.conjur.com.br/2009-jun11/anistia-nao-amnesia-oab-resposta-nelson-jobim. Acesso em 18 de fevereiro de 2012.

GASPARI, Elio. Bolsa Ditadura se transformou em indústria. Folha de São Paulo / O Globo. 28 de junho de 2009. Disponível em http://www.conjur.com.br/2009-jun-28/bolsaditadura-transformou-catedral-privilegios-malandragem. Acesso em 04 de janeiro de 2012.

Obs: Crítica à falta de critério para concessão de indenizações. 
ESTADO DE SÃO PAULO (jornal). Araguaia: Jobim explica trabalho de busca por ossadas. $O$ Estado de São Paulo. 09 de julho de 2009. Disponível em http://www.estadao.com.br/noticias/geral,araguaia-jobim-explica-trabalho-de-busca-porossadas, 400340,0.htm. Acesso em 18 de fevereiro de 2012.

\section{0}

SUPREMO TRIBUNAL FEDERAL. STF é contra a revisão da Lei da Anistia por sete votos a dois. Supremo Tribunal Federal. 29 de abril de 2010. Disponível em http://www.stf.jus.br/portal/cms/verNoticiaDetalhe.asp?idConteudo=125515\&caixaBusca= N. Acesso em 28 de abril de 2012.

CANTANHÊDE, Eliane. Militares recebem com alívio decisão do STF. Folha de São Paulo. 01 de maio de 2010. Disponível em http://www2.senado.gov.br/bdsf/item/id/215971. Acesso em 18 de fevereiro de 2012.

WEISSHEIMER, Marco Aurélio. "Decisão do STF é erro jurídico e deformação histórica". Carta Maior. 01 de maio de 2010. Disponível em http://www.cartamaior.com.br/templates/materiaMostrar.cfm?materia_id=16563. Acesso em 04 de janeiro de 2012.

Obs: Entrevista com Tarso Genro.

CONSULTOR JURÍDICO. Condenação do Brasil não anula decisão do Supremo. Consultor Jurídico. 15 de dezembro de 2010. Disponível em http://www.conjur.com.br/2010-dez-15/sentenca-corte-interamericana-nao-anula-decisaosupremo. Acesso em 18 de fevereiro de 2012.

\section{1}

CONSULTOR JURÍDICO. RS deve indenizar homem torturado na ditadura. Consultor Jurídico. 25 de abril de 2011. Disponível em http://www.conjur.com.br/2011-abr25/estado-indenizar-homem-foi-torturado-ditadura. Acesso em 04 de janeiro de 2012.

Obs: Relata decisão que determinou o pagamento de danos morais apesar da indenização (máxima) concedida pela Comissão Especial. Também considera que há imprescritibilidade da ação de indenização (não se aplica o prazo prescricional previsto no Decreto Federal 20.910, de 06 de janeiro de 1932).

\section{2}

FERRAZ, Lucas. O instante decisivo (Ilustríssima, p.6). Folha de São Paulo. 05 de fevereiro de 2012. Disponível em http://acervo.folha.com.br. Acesso em 12 de março de 2012. 
MINISTÉRIO PÚBLICO FEDERAL. MPF/RJ cria grupo de trabalho para investigar crimes cometidos durante a ditadura militar. Site do Ministério Público Federal. 07 de março de 2012. Disponível em http://noticias.pgr.mpf.gov.br/noticias/noticias-dosite/copy_of_criminal/mpf-rj-cria-grupo-de-trabalho-para-investigar-crimes-cometidosdurante-a-ditadura-militar-2. Acesso em 16 de julho de 2012.

MINISTÉRIO PÚBLICO FEDERAL. MPF assina ação contra Curió por seqüestros na guerrilha do Araguaia. Site do Ministério Público Federal. 13 de março de 2012. Disponível em http://noticias.pgr.mpf.gov.br/noticias/noticias-dosite/copy_of_criminal/mpf-denuncia-curio-por-sequestros-na-guerrilha-do-araguaia/.

Acesso em 16 de julho de 2012.

SUPREMO TRIBUNAL FEDERAL. STF adia, em uma sessão, a análise de recurso sobre a Lei de Anistia. Supremo Tribunal Federal. 22 de março de 2012. Disponível em http://www.stf.jus.br/portal/cms/verNoticiaDetalhe.asp?idConteudo=203265\&tip=UN.

Acesso em 28 de abril de 2012.

TOSTA, Wilson. Comissão da OEA investiga Brasil por Caso Herzog. Estado de São Paulo (jornal). 29 de março de 2012. Disponível em http://www.estadao.com.br/noticias/nacional,comissao-da-oea-investiga-brasil-por-casoherzog,855039,0.htm. Acesso em 28 de abril de 2012.

GLOBO G1. MPF denuncia delegado e coronel reformado por ações na ditadura. Globo.com G1. 24 de abril de 2012. Disponível em http://g1.globo.com/saopaulo/noticia/2012/04/mpf-denuncia-delegado-e-coronel-reformado-por-acoes-naditadura.html. Acesso em 16 de julho de 2012.

CREDENDIO, José Ernesto. Comissão da Verdade deve analisar os dois lados, diz integrante. Folha de São Paulo. 14 de maio de 2012. Disponível em http://www1.folha.uol.com.br/poder/1089951-comissao-da-verdade-deve-analisar-os-doislados-diz-integrante.shtml. Acesso em 16 de julho de 2012.

RONCAGLIA, Daniel. Manifestantes fazem novo 'esculacho' contra acusados de tortura. Folha de São Paulo. 14 de maio de 2012. Disponível em http://www1.folha.uol.com.br/poder/1090023-manifestantes-fazem-novo-esculachocontra-acusados-de-tortura.shtml. Acesso em 16 de julho de 2012.

COLOMBO, Sylvia. Argentina e Uruguai só julgaram agentes de Estado. Folha de São Paulo. 15 de maio de 2012. Primeiro Caderno, p. A4. Disponível em http://acervo.folha.com.br. Acesso em 16 de julho de 2012.

LUNA, Denise. Alvo de comissão é ditadura e não guerrilha, diz integrante. Folha de São Paulo. 15 de maio de 2012. Primeiro Caderno, p. A4. Disponível em http://acervo.folha.com.br. Acesso em 16 de julho de 2012.

CAMPANHA, Diógenes. Houve acordo para apurar esquerda, diz ex-ministro. Folha de São Paulo. 16 de maio de 2012. Primeiro Caderno, p. A13. Disponível em http://acervo.folha.com.br. Acesso em 16 de julho de 2012. 
FRANCO, Bernardo Mello. 10 perguntas para a Comissão da Verdade. Folha de São Paulo. 16 de maio de 2012. Primeiro Caderno, p. A12. Disponível em http://acervo.folha.com.br. Acesso em 16 de julho de 2012.

FERRAZ, Lucas. Governo nega indenização a Cabo Anselmo. Folha de São Paulo. 23 de maio de 2012. Primeiro Caderno, p. A10. Disponível em http://acervo.folha.com.br. Acesso em 16 de julho de 2012.

KACHANI, Morris. Integrante associa tortura a 'gozo proibido'. Folha de São Paulo. 16 de maio de 2012. Primeiro Caderno, p. A12. Disponível em http://acervo.folha.com.br. Acesso em 16 de julho de 2012.

SAVARESE, Maurício. Dilma instala comissão da verdade e diz que não haverá ressentimento, ódio nem perdão. UOL. 16 de maio de 2012. Disponível em http://noticias.uol.com.br/politica/ultimas-noticias/2012/05/16/dilma-chora-ao-instalarcomissao-da-verdade.htm. Acesso em 16 de julho de 2012.

SCHWARTSMAN, Hélio. A verdade da comissão. Folha de São Paulo. 16 de maio de 2012. Primeiro Caderno, p. A2. Disponível em http://acervo.folha.com.br. Acesso em 16 de julho de 2012.

FRANCO, Bernardo Mello. Justiça adia julgamento de recurso de Ustra. Folha de São Paulo. 23 de maio de 2012. Primeiro Caderno, p. A10. Disponível em http://acervo.folha.com.br. Acesso em 16 de julho de 2012.

GLOBO G1. Justiça nega ação contra militares acusados de seqüestra na ditadura. Globo.com G1. 23 de maio de 2012. Disponível em http://g1.globo.com/politica/noticia/2012/05/justica-nega-acao-contra-militares-acusadosde-sequestro-na-ditadura.html. Acesso em 16 de julho de 2012.

PEIXOTO, Paulo. 'Encarei a morte e a solidão', diz Dilma. Folha de São Paulo. 22 de junho de 2012. Primeiro Caderno, p.A10. Disponível em http://acervo.folha.com.br. Acesso em 16 de julho de 2012.

RODRIGUES, Fernando. 'Nem ódio, tampouco perdão', diz Dilma sobre tortura. Folha de São Paulo. 22 de junho de 2012. Disponível em http://www1.folha.uol.com.br/poder/1109149-nem-odio-tampouco-perdao-diz-dilmasobre-tortura.shtml. Acesso em 16 de julho de 2012.

VALENTE, Rubens. Militares vigiaram Lula durante 15 anos. Folha de São Paulo. 22 de junho de 2012. Primeiro Caderno, p.A11. Disponível em http://acervo.folha.com.br. Acesso em 16 de julho de 2012.

CAMPANHA, Diógenes. Brilhante Ustra é condenado por morte de jornalista nos anos 70. Folha de São Paulo. 26 de junho de 2012. Disponível em http://www1.folha.uol.com.br/poder/1110812-brilhante-ustra-e-condenado-por-morte-dejornalista-nos-anos-70.shtml. Acesso em 18 de agosto de 2012. 
FOLHA DE SÃO PAULO. Ex-agente repete relato à Comissão da Verdade. Folha de São Paulo. 26 de junho de 2012. Primeiro Caderno, p.A10. Disponível em http://acervo.folha.com.br. Acesso em 16 de julho de 2012.

JINKINGS, Daniella. Comissão da Verdade não vai convocar Dilma para depor. UOL. 26 de junho de 2012. Disponível em http://noticias.uol.com.br/politica/ultimasnoticias/2012/06/26/comissao-da-verdade-nao-vai-convocar-dilma-para-depor.htm. Acesso em 16 de julho de 2012.

COMISSÃO NACIONAL DA VERDADE. Comissão da Verdade define estratégias de funcionamento e estrutura. 2 de julho de 2012. Disponível em http://www.cnv.gov.br/noticias/02-07-2012-comissao-da-verdade-define-estrategias-defuncionamento-e-estrutural. Acesso em 03 de janeiro de 2013.

JORNAL DO ADVOGADO OAB/SP. Instituída a Comissão da Verdade da OAB/SP. Ano XXXVIII, Edição 374, Julho/2012, p.16/17

CREDENDIO, José Ernesto. TJSP nega recurso e reconhece coronel Ustra como torturador. Folha de São Paulo. 14 de agosto de 2012. Disponível em http://www1.folha.uol.com.br/poder/1137102-tj-sp-nega-recurso-e-reconhece-coronelustra-como-torturador.shtml. Acesso em 18 de agosto de 2012.

GENESTRETI, Guilherme. Faculdade de Direito da USP aprova 'Comissão da Verdade' na instituição. Folha de São Paulo. 27 de setembro de 2012. Disponível em http://www1.folha.uol.com.br/saopaulo/1160451-faculdade-de-direito-da-usp-aprovacomissao-da-verdade-na-instituicao.shtml. Acesso em 03 de janeiro de 2013.

\section{$\underline{\text { Legislação por Assunto }}$}

\section{Regime Militar - diplomas normativos importantes}

Ato Institucional $\mathrm{n}^{\mathrm{o}} 1$, de 9 de abril de 1964.

(Modifica a Constituição do Brasil de 1946 quanto à eleição, ao mandato e aos poderes do Presidente da República; confere aos Comandantes-em-chefe das Forças Armadas o poder de suspender direitos políticos e cassar mandatos legislativos, excluída a apreciação judicial desses atos; e dá outras providências)

Ato Institucional $\mathrm{n}^{\mathrm{o}} 2$, de 27 de outubro de 1965.

(Modifica a Constituição do Brasil de 1946 quanto ao processo legislativo, às eleições, aos poderes do Presidente da República, à organização dos três Poderes; suspende garantias de vitaliciedade, inamovibilidade, estabilidade e a de exercício em funções por tempo certo; exclui da apreciação judicial atos praticados de acordo com suas normas e Atos Complementares decorrentes; e dá outras providências.)

Constituição Federal, de 24 de janeiro de 1967.

Ato Institucional $\mathrm{n}^{\circ}$ 5, de 13 de dezembro de 1968.

(Suspende a garantia do habeas corpus para determinados crimes; dispõe sobre os poderes do Presidente da República de decretar: estado de sítio, nos casos previstos na 
Constituição Federal de 1967; intervenção federal, sem os limites constitucionais; suspensão de direitos políticos e restrição ao exercício de qualquer direito público ou privado; cassação de mandatos eletivos; recesso do Congresso Nacional, das Assembléias Legislativas e das Câmaras de Vereadores; exclui da apreciação judicial atos praticados de acordo com suas normas e Atos Complementares decorrentes; e dá outras providências)

Emenda Constitucional $\mathrm{n}^{\mathrm{o}} 1$, de 17 de outubro de 1969.

(Altera dispositivos da Constituição Federal e apresenta nova redação consolidada)

Emenda Constitucional $\mathrm{n}^{\circ} 11$, de 13 de outubro de 1978.

(Altera dispositivos da Constituição Federal e revoga os Atos Institucionais $e$ Complementares)

\section{Processo Político de Anistia - Principais Diplomas Normativos}

Lei Federal 6.683, de 28 de agosto de 1979.

(Lei de Anistia)

Decreto Federal 84.143, de 31 de outubro de 1979.

(Regulamenta a Lei de Anistia)

Decreto Federal 84.223 de 20 de novembro de 1979.

(Indulto de Natal que diminuiu as penas inclusive de criminosos políticos)

Emenda Constitucional n ${ }^{\circ}$ 26, de 27 de novembro de 1985

(Convoca Assembleia Nacional Constituinte e dá outras providências)

Constituição Federal da República Federativa do Brasil, de 05 de outubro de 1988.

Lei Federal 9.140, de 04 de dezembro de 1995

(Comissão de Mortos e Desaparecidos Políticos)

Lei Federal 10.559, de 13 de novembro de 2002.

(Lei do Regime de Anistiado Político)

Lei Federal 12.528, de 18 de novembro de 2011.

(Cria a Comissão Nacional da Verdade)

\section{Segurança Nacional}

Decreto-Lei 314, de 13 de março de 1967.

(Define os crimes contra a Segurança Nacional)

Decreto-Lei 510, de 20 de março de 1969.

(Altera dispositivos do Decreto-Lei 314/1967) 
Decreto-Lei 898, de 29 de setembro de 1969.

(Define os crimes contra a Segurança Nacional)

Decreto-Lei 975, de 20 de outubro de 1969.

(Dispõe sobre os crimes de contrabando e transporte de terroristas e subversivos praticados por meio de aeronaves)

Lei Federal 5.786, de 27 de junho de 1972.

(Define como crime contra a Segurança Nacional o apoderamento e o controle de aeronave)

Lei Federal 6.620, de 17 de dezembro de 1978.

(Define os crimes contra a Segurança Nacional)

Lei Federal 7.170, de 14 de dezembro de 1983. (atualmente em vigor)

(Define os crimes contra a Segurança Nacional)

\section{Sigilo de Documentos}

Decreto Federal 27.583, de 14 de dezembro de 1949.

(Aprova o Regulamento para Salvaguarda das Informações que interessam à Segurança Nacional)

Decreto Federal 60.417, de 11 de março de 1967.

(Aprova o Regulamento para Salvaguarda de Assuntos Sigilosos)

Decreto Federal 69.534, de 11 de novembro de 1971.

(Altera dispositivos do Regulamento para Salvaguarda de Assuntos Sigilosos)

Decreto Federal 79.099, de 6 de janeiro de 1977.

(Aprova o Regulamento para Salvaguarda de Assuntos Sigilosos)

Lei Federal 8.159, de 08 de janeiro de 1991.

(Dispõe sobre a Política Nacional de Arquivos Públicos e Privados)

Decreto Federal 2.134, de 24 de janeiro de 1997.

(Regulamenta o Art. 23 da Lei 8.159/1991, sobre acesso a documentos sigilosos)

Decreto Federal 2.910, de 29 de dezembro de 1998.

(Estabelece normas para salvaguarda de documentos e informações sigilosas)

Decreto Federal 4.497, de 4 de dezembro de 2002.

(Altera o Art. 17 do Decreto 2.134/1997)

Decreto Federal 4.553, de 27 de dezembro de 2002.

(Dispõe sobre o sigilo de documentos)

Medida Provisória 228, de 9 de dezembro de 2004.

(Dispõe sobre o sigilo de documentos) 
Decreto Federal 5.301, de 9 de dezembro de 2004.

(Regulamenta a MPV 228/2004)

Lei Federal 11.111, de 05 de maio de 2005. (Conversão da MPV 228/2004)

(Dispõe sobre o sigilo de documentos)

Lei Federal 12.527, de 18 de novembro de 2011. (atualmente em vigor)

(Lei de Acesso à Informação)

Decreto Federal 7.845, de 14 de novembro de 2012.

(Regulamenta procedimentos para o tratamento de informações sigilosas e dispõe sobre o Núcleo de Segurança e Credenciamento)

\section{Convenções Internacionais e Instrumentos de Internalização}

Carta das Nações Unidas, de 26 de junho de 1945. Promulgada pelo Decreto Federal n. 19.841, de 22 de outubro de 1945.

Obs: Entrada em vigor para o Brasil - 22 de outubro de 1945.

Convenção Americana sobre Direitos Humanos (Pacto de São José da Costa Rica), de 22 de novembro de 1969. Promulgada pelo Decreto Federal n. 678, de 06 de novembro de 1992.

Obs: Entrada em vigor para o Brasil - 25 de setembro de 1992

Decreto Federal 4.463, de 08 de novembro de 2002.

(Reconhece a competência da Corte Internacional de Direitos Humanos)

ESTATUTO DEL TRIBUNAL MILITAR INTERNACIONAL DE NUREMBERG, de 06 de outubro de 1945. (texto em espanhol) Disponível em http://www.ehu.es/ceinik/tratados/7TRATADOSRELATIVOSACRIMENESDEGUERRA /CG73.pdf. Acesso em 05 de janeiro de 2012.

ORGANIZAÇÃO DAS NAÇÕES UNIDAS. Resolução 95 (I), de 11 de dezembro de $1946 . \quad$ Disponível em http://daccess-ddsny.un.org/doc/RESOLUTION/GEN/NR0/033/46/IMG/NR003346.pdf?OpenElement.

Acesso em 05 de janeiro de 2012.

Obs: Afirma os princípios de direito internacional reconhecidos pelo Tribunal de Nuremberg, bem como seu julgamento.

ORGANIZAÇÃO DAS NAÇÕES UNIDAS. Resolução 2.338 (XXII), de 18 de dezembro de $1967 . \quad$ Disponível em http://daccess-ddsny.un.org/doc/RESOLUTION/GEN/NR0/236/73/IMG/NR023673.pdf?OpenElement.

Acesso em 05 de janeiro de 2012. 
Obs: Trata da importância de se reconhecer a imprescritibilidade de crimes contra a humanidade e crimes de guerra e decide dar prioridade à elaboração de convenção nesse sentido.

\section{Comissões Estaduais de Indenização}

$\underline{\text { Paraná }}$

Lei Estadual (Paraná) 11.255, de 21 de dezembro de 1995

(Comissão Especial para indenizações do Paraná)

Lei Estadual (Paraná) 13.570, de 21 de maio de 2002

(Estende o prazo dos efeitos da Lei 11.255/1995)

Lei Estadual (Paraná) 14.890, de 07 de novembro de 2005

(Estende novamente o prazo dos efeitos da Lei 11.255/1995)

$\underline{\text { www.legislacao.pr.gov.br }}$

\section{$\underline{\text { Rio Grande do Sul }}$}

Lei Estadual (Rio Grande do Sul) Lei 11.042, de 18 de novembro de 1997

(Comissão Especial para indenizações do Rio Grande do Sul)

$\underline{\text { www.al.rs.gov.br }}$

$\underline{\text { Minas Gerais }}$

Lei Estadual (Minas Gerais) 13.187, de 20 de janeiro de 1999

(Conselho Estadual de Direitos Humanos pode conceder indenizações)

Decreto Estadual (Minas Gerais) 41.239, de 28 de agosto de 2000

(Comissão Especial para indenizações de Minas Gerais)

www.almg.gov.br

$\underline{\text { São Paulo }}$

Lei Estadual (São Paulo) Lei 10.726, de 08 de janeiro de 2001

(Comissão Especial para indenizações de São Paulo) 


\section{Guerrilha do Araguaia (bibliografia complementar)}

BERCHT, Verônica. Coração Vermelho - A Vida de Elza Monnerat. São Paulo: Anita Garibaldi, 2002.

CABRAL, Pedro Corrêa. Xambioá: Guerrilha no Araguaia. Rio de Janeiro: Record, 1993.

CAMPOS FILHO, Romualdo Pessoa. Guerrilha do Araguaia - Esquerda em Armas. Goiânia: Universidade Federal de Goiás, 1997.

CARVALHO, Luiz Maklouf. O Coronel rompe o silêncio - Lício Augusto Ribeiro, que matou e levou tiros na caçada aos guerrilheiros do Araguaia, conta sua história. Rio de Janeiro: Objetiva, 2004.

GASPARI, Elio. A Ditadura Escancarada - As ilusões armadas. São Paulo: Companhia das Letras, 2002.

GORENDER, Jacob. Combate nas Trevas: a esquerda brasileira: das ilusões perdidas à luta armada. São Paulo. Ática, 1987.

MORAIS, Taís e SILVA, Eumano. Operação Araguaia - Arquivos Secretos da Guerrilha. Geração Editorial, 2005.

MOURA, Clóvis. Diário da Guerrilha do Araguaia. São Paulo: Alfa-Ômega, 1985.

PALMÉRIO, Dória. A Guerrilha do Araguaia. São Paulo: Alfa-Ômega, 1981.

POMPE, Carlos (preparação e revisão). Guerrilha do Araguaia - Documentos do $P C$ do $B$. São Paulo: Anita Garibaldi, 1996.

PORTELA, Fernando. Guerra de Guerrilhas no Brasil. São Paulo: Global, 1987.

PROJETO ORVIL (Tentativas de Tomada do Poder) (1987?)

Obra do exército não publicada.

SÁ, Glênio, Araguaia: relato de um guerrilheiro. São Paulo. Anita Garibaldi, 1990.

SOUZA, Aluísio Madruga de Moura e. Movimento Comunista Brasileiro; Guerrilha do Araguaia-Revanchismo: A Grande Verdade. Brasília: Edição do Autor, 2002.

STUDART, Hugo. A Lei da Selva, Geração Editorial, 2006. 


\section{Números da Comissão de Mortos e Desaparecidos Políticos (CEMDP)}

Primeira Fase

TOTAL DE PROCESSOS ${ }^{114}: 366$

Anexo ou não:

132 Anexo

234 Não-Anexo

Deferidos/Indeferidos:

148 deferidos

86 indeferidos

Conhecidos/Novos:

166 conhecidos (Dossiê dos Mortos e Desaparecidos)

68 novos

Indenizações Concedidas:

280

Final dos Trabalhos

TOTAL DE PROCESSOS: 471

Anexo ou não:

132 Anexo

339 Não-Anexo

Deferidos/Indeferidos:

221 deferidos

118 indeferidos

Indenizações Concedidas:

353

Araguaia

TOTAL DE PROCESSOS: 78 (16,5\% do total)

Anexo ou não:

60 Anexo

18 Não-Anexo

Obs: Aproximadamente 45\% dos casos do Anexo são relativos ao Araguaia.

Deferidos/Indeferidos:

2 deferidos

16 indeferidos

${ }^{114}$ Um processo por desaparecido. 
Indenizações Concedidas:

$62(17,5 \%$ do total $)$

\section{Números da Comissão de Anistia}

$\underline{\text { Requerimentos (2010) }}$

Apresentados: 68.517

Apreciados: 57.628

Deferimentos: 38.025

Indeferimentos: 19.603

$\underline{\text { Indenizações (2010) }}$

Prestação Única: R\$ 215.331.511,13

Prestação Continuada: $\mathrm{R} \$ 36.404 .755,92$

Total: R\$251.736.267,05

\section{Filmes e Documentários}

15 FILHOS. Dirigido por Maria Oliveira e Marta Nehring, 1996. Brasil (São Paulo). Duração: 20 min (aprox.).

Disponível em: http://www.youtube.com/watch?v=u-Lwh9u7ojI

Disponível em:

http://www.vermelho.org.br/pe/noticia.php?id_secao=91\&id_noticia $=172473$

ARAGUAYA - A CONSPIRAÇÃO DO SILÊNCIO. Dirigido por Ronaldo Duque, 2003. Brasil (Brasília/DF).

BATISMO DE SANGUE. Dirigido por Helvécio Ratton, 2006. Brasil (Belo Horizonte/MG).

CABRA MARCADO PARA MORRER. Dirigido por Eduardo Coutinho, 1984. Brasil (Rio de Janeiro/RJ).

LAMARCA. Dirigido por Sérgio Rezende, 1994. Brasil (Rio de Janeiro/RJ).

O ANO EM QUE MEUS PAÍS SAÍRAM DE FÉRIAS. Dirigido por Cao Hamburger, 2006. Brasil (São Paulo/SP).

O QUE É ISSO COMPANHEIRO? Dirigido por Bruno Barreto, 1997. Brasil (Rio de Janeiro/RJ). 


\section{$\underline{\text { Jurisprudência (Responsabilidade Civil) }}$}

Descrição de breve pesquisa exploratória realizada no site do Superior Tribunal de Justiça sobre a responsabilidade civil do Estado pelas torturas e execuções cometidas no regime militar.

Argumento de pesquisa: "regime militar"

Resultados: 58 acórdãos encontrados. 53 acórdãos pertinentes referentes a 50 casos diferentes $^{115}$.

Data: Pesquisa realizada em 09 de janeiro de 2012.

Conclusões a partir da leitura das ementas:

a) As ações de reparação por danos decorrentes dos atos de exceção praticados no regime militar são imprescritíveis.

b) Ausência de previsão orçamentária não justifica que o Estado deixe de pagar, mas pode fazer com o que o pagamento seja realizado por precatório.

c) Em alguns dos casos foi possível encontrar referência ao valor de indenização que o Estado foi condenado a pagar. Em todos os casos o valor de indenização determinado pela segunda instância foi mantido pelo Superior Tribunal de Justiça.

\begin{tabular}{|c|c|c|c|}
\hline $\mathbf{N}^{0}$ & Caso & Indenização & Data Julgamento \\
\hline 1 & AgRg no REsp 1229046 / RJ & $\mathrm{R} \$ 150.000,00$ & $08 / 11 / 2011$ \\
\hline 2 & AgRg no Ag $1337260 /$ PR & $\mathrm{R} \$ 100.000,00$ & $06 / 09 / 2011$ \\
\hline \multirow[t]{3}{*}{3} & AgRg no REsp 1042632 / GO & $\mathrm{R} \$ 400.000,00$ & $02 / 06 / 2011$ \\
\hline & $\begin{array}{l}\text { EDcl no AgRg no REsp } \\
1042632 \text { / GO }\end{array}$ & $\mathrm{R} \$ 400.000,00$ & $22 / 09 / 2009$ \\
\hline & AgRg no REsp 1042632 / GO & $\mathrm{R} \$ 400.000,00$ & $16 / 09 / 2008$ \\
\hline 4 & AgRg no REsp 1160643 / RN & $\mathrm{R} \$ 300.000,00$ & 23/11/2010 \\
\hline 5 & AgRg no REsp 1056333 / RJ & 200 salários mínimos & $25 / 05 / 2010$ \\
\hline 6 & REsp 959904 / PR & $\mathrm{R} \$ 100.000,00$ & $23 / 04 / 2009$ \\
\hline 7 & REsp 1085358 / PR & $\mathrm{R} \$ 100.000,00$ & $23 / 04 / 2009$ \\
\hline 8 & REsp 1104731 / RS & $\mathrm{R} \$ 300.000,00$ & $05 / 03 / 2009$ \\
\hline 9 & REsp 841410 / RJ & $\mathrm{R} \$ 100.000,00$ & $18 / 12 / 2008$ \\
\hline \multirow[t]{2}{*}{10} & REsp 651512 / GO & $\mathrm{R} \$ 300.000,00$ & 10/04/2007 \\
\hline & $\begin{array}{lll}\text { TOTAL } & \text { (aproximado } & \text { e } \\
\text { histórico) } & \end{array}$ & $\underline{\mathrm{R} \$ 2.770 .00,00}$ & \\
\hline
\end{tabular}

* Utilizou-se um valor de R \$ 600,00 para o salário mínimo nos cálculos.

\footnotetext{
${ }^{115}$ Por vezes havia diferentes acórdãos referentes a um mesmo caso. Isso acontece quando há recursos dentro do próprio Tribunal, como Embargos de Declaração ou Agravo Regimental.
} 
Os valores totais referentes a apenas 10 casos é de mais de dois milhões e setecentos mil reais (média de mais de $\mathrm{R} \$ 250$ mil por caso), o que mostra a relevância dos valores de indenização pagos. Assim, verifica-se a importância de estudos sobre a responsabilidade civil do Estado em casos relacionados ao regime militar. 


\section{Processos}

\begin{tabular}{|c|c|c|c|c|c|c|c|c|}
\hline Nome do Caso & Processo & Pólo Ativo & Pólo Passivo & Fórum & Ação & Recurso & Vara/Turma & Principais Movimentações \\
\hline $\begin{array}{l}\text { Regresso contra os } \\
\text { torturadores }\end{array}$ & $\begin{array}{c}0011414- \\
28.2008 .4 .03 .6100\end{array}$ & $\begin{array}{c}\text { Ministério } \\
\text { Público Federal }\end{array}$ & $\begin{array}{c}\text { União Federal, } \\
\text { Carlos Alberto } \\
\text { Brilhante Ustra, } \\
\text { Audir Santos } \\
\text { Maciel }\end{array}$ & $\begin{array}{l}\text { JFSP / } \\
\text { TRF3 }\end{array}$ & $\begin{array}{l}\text { Ação Civil } \\
\text { Pública }\end{array}$ & Apelação & \begin{tabular}{|c} 
8a Vara Cível \\
São Paulo / \\
3a Turma \\
TRF3
\end{tabular} & $\begin{array}{l}\text { - Distribuição em 14.05.2008 } \\
\text { - Sentença improcedente em } \\
30.06 .2010 \\
\text { - Apelação interposta pelo } \\
\text { Ministério Público Federal } \\
\text { • Distribuída ao TRF3 em } \\
\text { 17.01.2011 }\end{array}$ \\
\hline $\begin{array}{l}\text { Angela Almeida e } \\
\text { Regina Almeida x } \\
\text { Coronel Ustra }\end{array}$ & $\begin{array}{c}583.00 .2010 .175507- \\
9 \\
(1746 / 2010)\end{array}$ & $\begin{array}{c}\text { Angela Maria } \\
\text { Mendes de } \\
\text { Almeida, Regina } \\
\text { Maria Merlino } \\
\text { Dias de Almeida }\end{array}$ & $\begin{array}{l}\text { Carlos Alberto } \\
\text { Brilhante Ustra }\end{array}$ & TJSP & Ação Ordinária & - & $\begin{array}{l}\text { 20ạ Vara } \\
\text { Cível São } \\
\text { Paulo (Foro } \\
\text { Central) }\end{array}$ & $\begin{array}{l}\text { - Distribuição em 24.08.2010 } \\
\text { - Despacho em 28.02.2011, } \\
\text { rejeitando as preliminares do } \\
\text { Réu } \\
\text { - Audiência em 27.07.2011, } \\
\text { conciliação e oitiva de } \\
\text { testemunhas } \\
\text { - Despacho encerrando a } \\
\text { instrução em } 04.05 .2012\end{array}$ \\
\hline
\end{tabular}




\begin{tabular}{|c|c|c|c|c|c|c|c|c|}
\hline $\begin{array}{l}\text { Família Teles } x \\
\text { Coronel Ustra }\end{array}$ & $\begin{array}{c}\text { 583.00.2005202853-5 } \\
\text { (1978/2005) (1a } \\
\text { Instância) / } \\
\text { 0347718- } \\
\text { 08.2009.8.26.0000 (2a } \\
\text { Instância) }\end{array}$ & $\begin{array}{l}\text { César Augusto } \\
\text { Teles, Edson Luis } \\
\text { de Almeida } \\
\text { Teles, Janaína de } \\
\text { Almeida Teles, } \\
\text { Maria Amélia de } \\
\text { Almeida Teles e } \\
\text { Criméria Alice } \\
\text { Schmidt de } \\
\text { Almeida }\end{array}$ & $\begin{array}{l}\text { Carlos Alberto } \\
\text { Brilhante Ustra }\end{array}$ & TJSP & $\begin{array}{c}\text { Ação } \\
\text { Declaratória }\end{array}$ & Apelação & $\begin{array}{c}\text { 13a Vara } \\
\text { Cível São } \\
\text { Paulo (Foro } \\
\text { Central) / }\end{array}$ & \begin{tabular}{|l} 
- Distribuição em 01.12.2005 \\
- Despacho em 11.09.2006, \\
rejeitando as preliminares do \\
Réu \\
• Sentença em 07.10.2008, \\
declarando procedente o \\
pedido de César, Maria e \\
Criméria e declarando \\
improcedente o pedido de \\
Janaína e Edson \\
•Decisão em 04.11.2008, \\
rejeitando os Embargos de \\
Declaração do Réu \\
- Apelação distribuída em \\
19.05.2009 \\
- Incluído em pauta para \\
julgamento em 22.05.2012 e \\
retirado de pauta na mesma \\
data
\end{tabular} \\
\hline $\begin{array}{l}\text { Denúncia Penal } \\
\text { (Ustra e Gravina) }\end{array}$ & $\begin{array}{c}\text { 0004204- } \\
32.2012 .4 .03 .6181\end{array}$ & $\begin{array}{c}\text { Ministério } \\
\text { Público Federal }\end{array}$ & $\begin{array}{c}\text { Carlos Alberto } \\
\text { Brilhante Ustra e } \\
\text { Dirceu Gravina }\end{array}$ & $\begin{array}{l}\text { JFSP / } \\
\text { TRF3 }\end{array}$ & $\begin{array}{c}\text { Representação } \\
\text { Criminal }\end{array}$ & $\begin{array}{c}\text { Recurso em } \\
\text { Sentido } \\
\text { Estrito }\end{array}$ & $\begin{array}{c}\text { 10a Vara / 2a } \\
\text { Turma }\end{array}$ & $\begin{array}{l}\text { - Distribuição em } 24.04 .2012 \\
\text { - Sentença rejeitando a } \\
\text { denúncia em } 29.05 .2012 \\
\text { - Recurso em Sentido Estrito } \\
\text { em } 16.07 .2012 \\
\text { - Contrarrazões em } 25.07 .2012 \\
\text { - Recebidos os autos pelo TRF3 } \\
\text { em 24.09.2012 } \\
\text { - Julgamento iniciado em } \\
\text { 11.12.2012. Voto do Relator } \\
\text { (Des. Peixoto Junior) nega } \\
\text { provimento ao recurso. Des. } \\
\text { Nelton dos Santos pede vista. }\end{array}$ \\
\hline
\end{tabular}




\begin{tabular}{|c|l|}
\hline Nome do Caso & Resumo do Caso \\
\hline Regresso contra os torturadores & $\begin{array}{l}\text { Trata-se de ação ajuizada pelo Ministério Público Federal requerendo que torturadores do Regime Militar realizem o ressarcimento do } \\
\text { erário pelas indenizações pagas pela União Federal em virtude das torturas. Em primeira instância a ação foi julgada improcedente e o } \\
\text { Ministério Público Federal apelou. O processo encontra-se no Tribunal Regional Federal da 3a Região aguardando julgamento. }\end{array}$ \\
\hline $\begin{array}{c}\text { Angela Almeida e Regina Almeida x } \\
\text { Coronel Ustra }\end{array}$ & $\begin{array}{l}\text { Trata-se de ação requerendo a indenização por dano moral em virtude da tortura de Eduardo Merlino. As preliminares do Réu } \\
\text { denunciando à lide o Exército Brasileiro e fazendo referência à Ação Civil Pública em trâmite na Justiça Federal de São Paulo foram } \\
\text { rejeitadas. Houve instrução do processo por meio da oitiva de testemunhas. A instrução foi declarada encerrada e o processo está na } \\
\text { conclusão aguardando julgamento. }\end{array}$ \\
\hline Família Teles x Coronel Ustra & $\begin{array}{l}\text { Trata-se de ação requerendo a declaração de relação jurídica de responsabilidade civil por prática de ato ilíito gerador de danos } \\
\text { morais. As preliminares do Réu foram rejeitadas. Após a instrução a sentença declarou a ação procedente para os Autores César, } \\
\text { Maria e Criméria e declarou a ação improcedente para os Autores Janaína e Edson. Os embargos de declaração do Réu foram } \\
\text { rejeitados. Houve Apelação e o processo encontra-se no Tribunal de Justiça de São Paulo aguardando julgamento. }\end{array}$ \\
\hline
\end{tabular}




\section{APÊNDICE IV \\ MAPA ARGUMENTATIVO DO CASO ARAGUAIA}

\section{Observações sobre o Mapa:}

- Sempre que possível indicamos qual o esquema do argumento que dá base à elaboração do argumento dentro do conjunto de esquemas apresentado nos Capítulos 1 e 2. Duas observações são importantes:

(i) Por vezes o "encaixe" do argumento no esquema não é tão evidente. Isso ocorre porque às vezes o esforço para tornar o encaixe claro prejudica a exposição dos argumentos, tornando o Mapa mais longo ou até mesmo mais confuso.

(ii) Por vezes não fomos capazes de "encaixar" o argumento em nenhum dos esquemas que apresentamos. Vale lembrar que o conjunto de esquemas dos Capítulos 1 e 2 é útil, mas limitado.

- Para mostrar que o Mapa foi construído a partir da reconstrução discussão real, por vezes identificamos as fontes em que nos inspiramos para elaborar os argumentos. Não o fizemos nos casos em que os argumentos ou proposições são utilizados por muitas pessoas, devendo então ser consultadas as referências bibliográficas do trabalho. Para os casos em que a inspiração principal do argumento foi a nossa reflexão, indicamos como fonte "analista".

- Os argumentos por vezes possuem comentários individuais do analista. As seções de discussões, divididas como no Capítulo 3 e no Mapa Argumentativo no nível do problema, também.

- Os argumentos estão ordenados de acordo com sua apresentação no texto do Capítulo 3 para facilitar o acompanhamento.

- PM significa que a proposição é dos Pró-Militares e CM que a proposição é dos Contra Militares.

- Quando uma proposição for oposta à outra a oposição será indicada por meio de um asterisco e individualização da outra proposição, de acordo com o exemplo: $P 1\left({ }^{*} P 2 P M\right)$

- Quando uma proposição for igual à outra logo após a sua individualização será indicada a igualdade, de acordo com o exemplo: $C 2(=P 2)$ 


\section{Nível do Problema: (Questões)}

\section{I. $\underline{\text { Responsabilizacão }}$}

Premissa (implícita e não discutida)

- Os acontecimentos do regime militar (tortura, assassinato, desaparecimentos forçados) foram graves e alguém precisa ser responsabilizado de alguma forma.

\section{I.1 O Direito (Processo Judicial/Administrativo) como meio de} responsabilização

\section{I.1.A Penal (Militares)}

\section{I.1.A.1 Objeções Filosófico-Jurídicas}

- Finalidades da Pena: A punição dos militares atende às finalidades da pena? (retribuição, prevenção geral positiva, prevenção geral negativa, prevenção especial negativa)

\section{I.1.A.2 Objeções Jurídicas Abstratas}

- Anistia: Houve anistia dos militares (Lei 6.683/1979)?

- Retroatividade: Há retroatividade penal caso os militares sejam punidos?

\section{I.1.A.3 Objeções Jurídicas Concretas}

- Prescrição: Houve prescrição dos crimes cometidos pelos militares?

- Provas e Responsabilidade Individual: É possível, após tanto tempo, provar de maneira satisfatória a participação dos militares e responsabilizá-los penalmente nos casos concretos?

\section{I.1.A.4 Considerações Políticas, Morais e de Justiça ${ }^{1}$}

- Questão Preliminar: As objeções políticas devem ser levadas em consideração na tomada de decisão jurídica?

- Política X Direito (1): Ainda que seja juridicamente possível punir penalmente, é a melhor escolha?

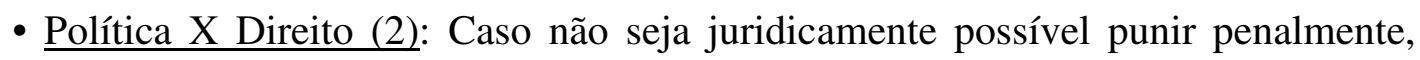
deve haver punição penal ainda assim?

\section{I.1.B Administrativa (Estado) \\ I.1.C Cível (Militares e Estado)}

\section{I.2 Outros meios de responsabilização}

\section{I.2.A Moral}

\footnotetext{
${ }^{1}$ Os mesmos questionamentos que são feitos em relação à política podem ser feitos para a Moral e para a Justiça.
} 


\section{I.2.B Social/Política}

I.3 Quanta responsabilização é suficiente? (Qual o melhor meio de responsabilizar dentre os meios à disposição?)

\section{Verdade e Memória}

Premissas (implícitas e não discutidas)

- A verdade sobre o que aconteceu no regime militar é importante e deve ser descoberta.

- A preservação da memória do que aconteceu de grave no regime militar é importante e deve ser realizada.

Questões

II.1 Qual o melhor meio para descobrir a verdade sobre o período do regime militar?

II.1.A O Direito como meio para descobrir a verdade

II.1.A.1 Considerações Preliminares

- Direito à Verdade: Há um direito à verdade?

- Processo Judicial: O processo judicial é uma maneira eficaz de buscar a verdade? Há dificuldades jurídico-processuais que prejudicam a busca da verdade pelo processo judicial? Diferentes regimes processuais prejudicam a busca de maneiras diferentes (civil, penal)?

- Comissões: As Comissões da Verdade são uma maneira eficaz de buscar a verdade?

II.1.B Problemas na busca pela verdade

- Problema Teórico: Existe uma verdade a ser buscada?

- Problema Fático: Há dificuldades fáticas que impedem a busca da verdade?

II.2 Qual o melhor meio para preservar a memória do que aconteceu de grave no regime militar? 


\section{Nível das Proposições: (Argumentos, Premissas e Conclusões)}

\section{I.1.A.2 Objeções Jurídicas Abstratas}

- Anistia: Houve anistia dos militares (Lei 6.683/1979)?

\section{Correta Interpretacão da Lei da Anistia}

\section{$\underline{\text { Pró-Militares }}$}

Argumento A (Anistia dos Militares)

Pl O Art. $1^{\circ}$, caput da Lei de Anistia diz que os crimes conexos aos crimes políticos são anistiados.

$P 2$ Os crimes praticados pelos militares foram conexos.

C1 Os militares foram anistiados.

Fonte: -

Esquema: Justificação - Aplicação de Norma Jurídica

\section{Conexão por crimes praticados uns contra os outros}

\section{$\underline{\text { Pró-Militares }}$}

Argumento B (Conexão - Uns contra os outros)

P3 O Art. 76, I do Código de Processo Penal diz que são conexos os crimes praticados por pessoas umas contra as outras.

P4 No caso concreto os militares e os grupos de oposição praticaram crimes uns contra os outros.

$C 2(=P 2)$ Os crimes praticados pelos militares foram conexos.

Fonte: Petição Inicial ADPF 153

Esquema: Justificação - Aplicação de Norma Jurídica

Argumento C (Conexão - Esquerda praticou crimes comuns)

P5 Os grupos de oposição praticaram crimes comuns além de crimes políticos.

$C 3\left({ }^{*} P 5 C M\right)$ Os grupos de oposição praticaram crimes contra os militares.

Fonte: -

Esquema: -

Nota: Assume-se P5 como verdadeiro. Ver relato histórico. 


\section{$\underline{\text { Contra Militares }}$}

Argumento A (Uns contra os outros é processual)

P1 A regra do Art. 76, I do Código de Processo Penal é apenas processual, tratando da unificação da competência para o julgamento de crimes.

$P 2 \mathrm{O}$ conceito de conexão da Lei de Anistia é material e não processual.

C1 Não há conexão entre os crimes militares e os crimes políticos nos termos do Art. 76, I do Código de Processo Penal.

Fonte: Petição Inicial ADPF 153

Esquema: Operacionalização - Exceção

Nota: Assumem-se P1 e P2 como verdadeiros no debate, dispensando-se o argumento de justificação nos termos do Esquema do Argumento.

Argumento B (Não houve uns contra os outros)

P3 Crimes políticos não são praticados contra pessoas, mas contra a ordem política.

$P 4$ Os grupos de oposição praticaram crimes políticos.

$P 5$ Os grupos de oposição não praticaram crimes contra os militares.

$C 2\left({ }^{*} P 4 P M\right)$ Os militares e os grupos de oposição não praticaram crimes uns contra os outros.

Fonte: Petição Inicial ADPF 153

Esquema: Operacionalização - Exceção

Nota: Assumem-se P1 e P2 como verdadeiros no debate, dispensando-se o argumento de justificação nos termos do Esquema do Argumento.

\section{Comentários}

- Os Argumentos $\mathrm{B}(\mathrm{PM})$ e $\mathrm{C}(\mathrm{PM})$ só fazem diferença para os casos em que houve prática de crimes uns contra os outros, o que pode ter que ser aferido concretamente. Assim, $\mathrm{P} 4(\mathrm{PM})$ fica restringido, pois nem todos os crimes praticados seriam conexos e, portanto, nem todos os militares teriam sido anistiados. Se a fundamentação de P2(PM) for, em última instância, o Argumento C, C1(PM) deixa de se estender a todos os militares. 


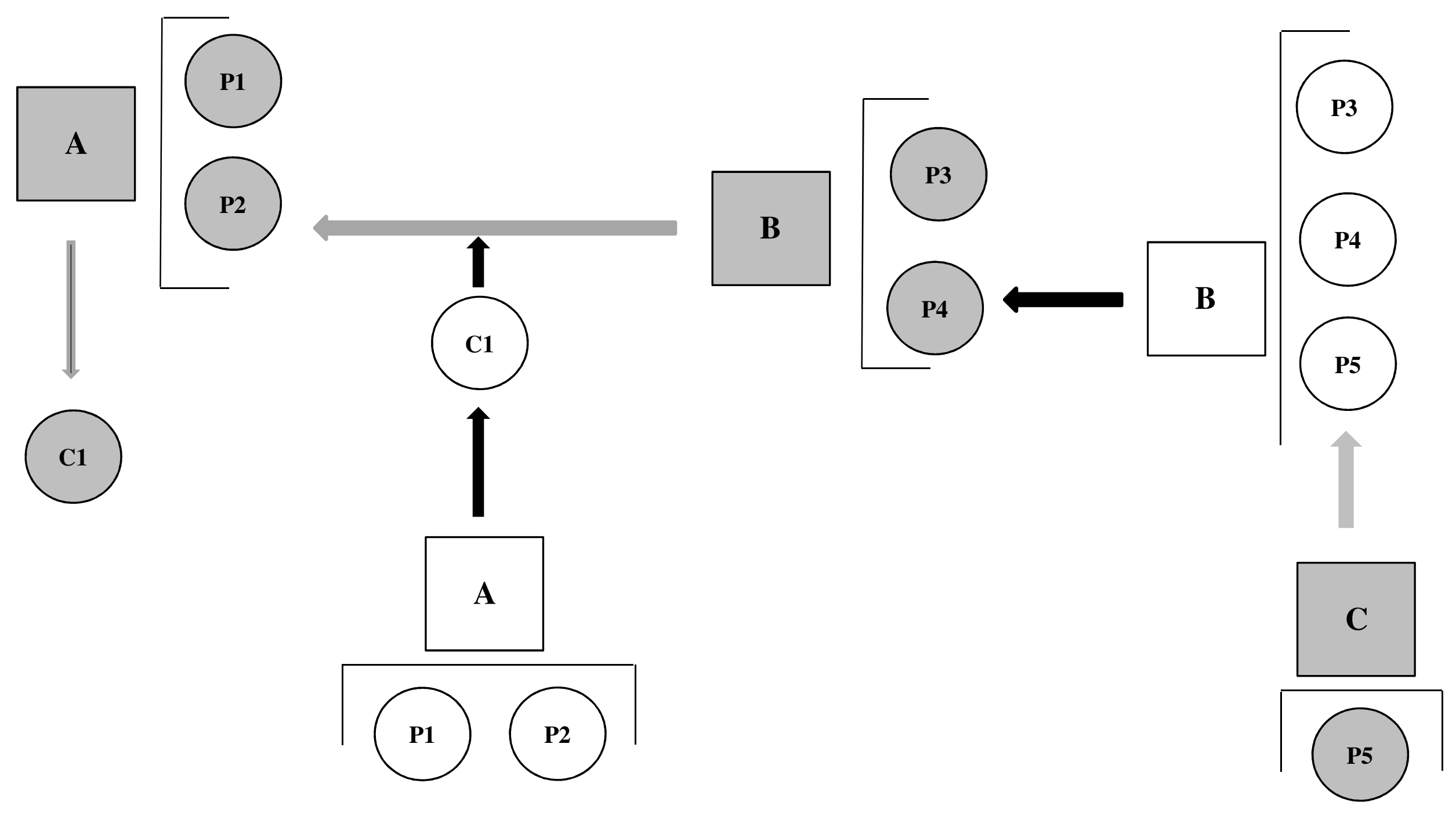




\section{Conexão pelos crimes terem sido praticados com motivação política}

\section{$\underline{\text { Pró-Militares }}$}

Argumento B (Conexão - Motivação Política)

P3 O $\S 1^{\circ}$ do Art. $1^{\circ}$ da Lei de Anistia diz que são conexos os crimes praticados por motivação política.

P4 Os militares tinham motivação política na prática dos crimes

$C 2(=P 2)$ Os crimes praticados pelos militares foram conexos.

Fonte: -

Esquema: Justificação - Aplicação de Norma Jurídica

Argumento C (Lei não tem palavras inúteis - Reafirmar o regime é motivação política)

P5 A lei não possui palavras inúteis ou redundantes.

P6 O conceito de crime político adotado pressupõe a motivação de contestar o regime.

$P 7$ Se motivação política for apenas a de contestar o regime, o texto da lei será redundante.

C3 A motivação política $\S 1^{\circ}$ do Art. $1^{\circ}$ da Lei de Anistia não é apenas a de contestar o regime político vigente.

Fonte: Swensson Jr., 2010, p. 39/40, rodapé 52

Esquema: Justificação - Aplicação de norma jurídica.

Nota: P5 é uma norma interpretativa. Observe-se que o argumento funciona como uma exceção, mas a justificativa já é dada desde logo no argumento (a norma interpretativa).

\section{Argumento D (Conexão - Motivação Política dos Dois Lados)}

P8 A motivação política do $\S 1^{\circ}$ do Art. $1^{\circ}$ da Lei de Anistia também inclui a motivação de defender e reafirmar o regime político vigente.

P9 Os crimes dos militares tinham o intuito de defender e reafirmar o regime político vigente.

$C 4(=P 4)$ Os militares tinham motivação política na prática dos crimes.

Fonte: Swensson Jr., 2010, p. 39/40

Esquema: Operacionalização - Exceção

\section{Argumento E (Int. Legislador - Motivação Política - Parte 2)}

P10 Ao decidir o que faz parte de um conceito jurídico deve se atender à intenção do legislador real.

P11 O legislador real entendeu que a motivação política do $\S 1^{\circ}$ do Art. $1^{\circ}$ da Lei de Anistia inclui a motivação de defender e reafirmar o regime político vigente.

$C 5(=P 8)$ A motivação política do $\S 1^{\circ}$ do Art. $1^{\circ}$ da Lei de Anistia também inclui a motivação de defender e reafirmar o regime político vigente.

Fonte: -

Esquema: Justificação - Aplicação de Norma Jurídica 
Nota: A norma aplicada é de interpretação (P10).

Argumento F (Int. Legislador - Motivação Política - Parte 1)

P12 A intenção do legislador real da Lei de Anistia era anistiar os militares.

P13 Se a motivação política do $\S 1^{\circ}$ do Art. $1^{\circ}$ da Lei de Anistia não incluir a motivação de defender e reafirmar o regime político vigente os militares não serão anistiados.

$C 6(=P 11)$ O legislador real entendeu que a motivação política do $\S 1^{\circ}$ do Art. $1^{\circ}$ da Lei de Anistia inclui a motivação de defender e reafirmar o regime político vigente.

Fonte: -

Esquema: Justificação - Objetivo da Lei

Argumento G (Negociação Política)

P14 Houve uma negociação política na qual se acordou que a anistia seria para a oposição e também para os militares.

$C 7(=P 12)$ A intenção do legislador real da Lei de Anistia era anistiar os militares.

Fonte: APDF 153, Voto do Min. Eros Grau, p. 24-28.

Esquema: -

\section{$\underline{\text { Contra Militares }}$}

Argumento A (Conexão - Não houve Motivação Política)

P1 A motivação política do $\S 1^{\circ}$ do Art. $1^{\circ}$ da Lei de Anistia é a motivação de contestar o regime político vigente.

$P 2$ Os crimes dos militares não tinham o intuito de contestar o regime político vigente.

$C 1(* P 4 P M)$ Os militares não tinham motivação política na prática dos crimes.

Fonte: -

Esquema: -

Argumento B (Reabertura Política e Oposição ao Regime)

P3 O contexto da Lei de Anistia era de reabertura política gradual.

P4 Em um contexto de reabertura política faz sentido permitir/perdoar a oposição/contestação do regime.

$C 2(=P 1)$ A motivação política do $\S 1^{\circ}$ do Art. $1^{\circ}$ da Lei de Anistia é a motivação de contestar o regime político vigente.

Fonte: Analista

Esquema: Justificação - Objetivo da Lei. 


\section{Argumento C (Falta de Clareza Conceito de Crime Político)}

P5 Não há clareza quanto ao conceito de crime político.

P6 A expressão "motivação política" garante que todos aqueles que contestaram o regime possam ser anistiados.

$C 3(* P 7 P M)$ Se a motivação política for apenas a de contestar o regime, a lei não será redundante.

Fonte: Analista

Esquema: -

Argumento D (Conexão - Incoerência em anistiar torturas, assassinatos $e$ desaparecimentos forçados)

P7 $\mathrm{O} \S 2^{\circ}$ do Artigo $1^{\circ}$ da Lei de Anistia exclui expressamente os "condenados pela prática de crimes de terrorismo, assalto, sequestro e atentado pessoal".

P8 O governo justificou o $\S 2^{\circ}$ do Artigo $1^{\circ}$ da Lei de Anistia dizendo que não poderia aceitar a anistia de atrocidades cometidas pela oposição, chamadas de "crimes contra a humanidade".

P9 Permitir que torturas, assassinatos e desaparecimentos forçados cometidos pelos militares sejam anistiados seria incoerente com o texto e razões da lei.

C4 Não se pode permitir que torturas, assassinatos e desaparecimentos forçados cometidos pelos militares sejam anistiados.

Fonte: Analista

Esquema: Justificação - Objetivo da Lei.

Argumento E (Conexão - Jurisprudência do STF sobre crimes políticos)

P10 A jurisprudência do STF avalia se um crime pode ser considerado politicamente motivado de acordo com a preponderância das razões e a atrocidade dos meios.

P11 Torturas, assassinatos e desaparecimentos forçados são crimes atrozes que não podem ser considerados politicamente motivados.

C4 Não se pode permitir que torturas, assassinatos e desaparecimentos forçados cometidos pelos militares sejam anistiados.

Fonte: ADPF 153, Voto Min. Ricardo Lewandowski, p.118/127

Esquema: Justificação - Tradição (Jurisprudência).

Argumento F (Conexão - Jurisprudência do STF sobre crimes políticos)

P10 A jurisprudência do STF avalia se um crime pode ser considerado politicamente motivado de acordo com a preponderância das razões e a atrocidade dos meios.

C5 Deve ser realizada análise caso a caso antes de concluir-se pela inclusão de um crime no rol dos beneficiados pela anistia.

Fonte: ADPF 153, Voto Min. Ricardo Lewandowski, p.118/127

Esquema: Justificação - Tradição (Jurisprudência) 
P12 Negociação pressupõe paridade de armas.

P13 Não havia paridade de armas entre os militares e os grupos de oposição.

$C 6(* P 14 P M)$ Não houve uma negociação política na qual se acordou que a anistia seria para a oposição e também para os militares.

Fonte: Analista

Esquema: Operacionalização - Exceção.

Nota: P12 se justifica por referência a uma característica que notoriamente se atribui às negociações. P13 está sustentada pelo relato histórico.

Argumento H (Não houve negociação efetiva, clara e aberta) (Victor)

P14 Em uma negociação o tema negociado deve ser discutido de maneira efetiva, clara e aberta.

P15 Não houve negociação efetiva clara e aberta sobre a anistia dos militares.

$C 6\left({ }^{*} P 14 P M\right)$ Não houve uma negociação política na qual se acordou que a anistia seria para a oposição e também para os militares.

Fonte: Analista

Esquema: Operacionalização - Exceção.

Nota: P14 se justifica por referência a uma característica que notoriamente se atribui às negociações. P15 está sustentada pelo relato histórico.

Argumento I (Parte da oposição não tinha motivos suficientes para negociar) (Victor)

P16 Pressupõe-se que as partes possuem motivos suficientes para negociar (algo a dar em troca e algo a receber de valores próximos).

P17 Parte da oposição não ofereceu resistência armada, mas sofreu com torturas, assassinatos e desaparecimentos, não tendo motivos suficientes para negociar.

C6 ( ${ }^{*}$ P14PM) Não houve uma negociação política na qual se acordou que a anistia seria para a oposição e também para os militares.

Fonte: Autor

Esquema: Operacionalização - Exceção.

Nota: P16 se justifica por referência a uma característica que notoriamente se atribui às negociações. P17 está sustentada pelo relato histórico.

\section{$\underline{\text { Comentários }}$}

- O Argumento E(PM) também é utilizado como exceção aos argumentos de que as atrocidades não poderiam ser consideradas anistiadas em virtude do texto e das razões da lei, bem como da jurisprudência do STF. A ideia é que a vontade do legislador fático ou real se sobreporia à vontade do legislador racional.

- Para os Argumentos $\mathrm{G}(\mathrm{CM}), \mathrm{H}(\mathrm{CM})$ e $\mathrm{I}(\mathrm{CM})$ não foram abordados todos os detalhes fáticos porque eles iriam sobrecarregar o mapa. 


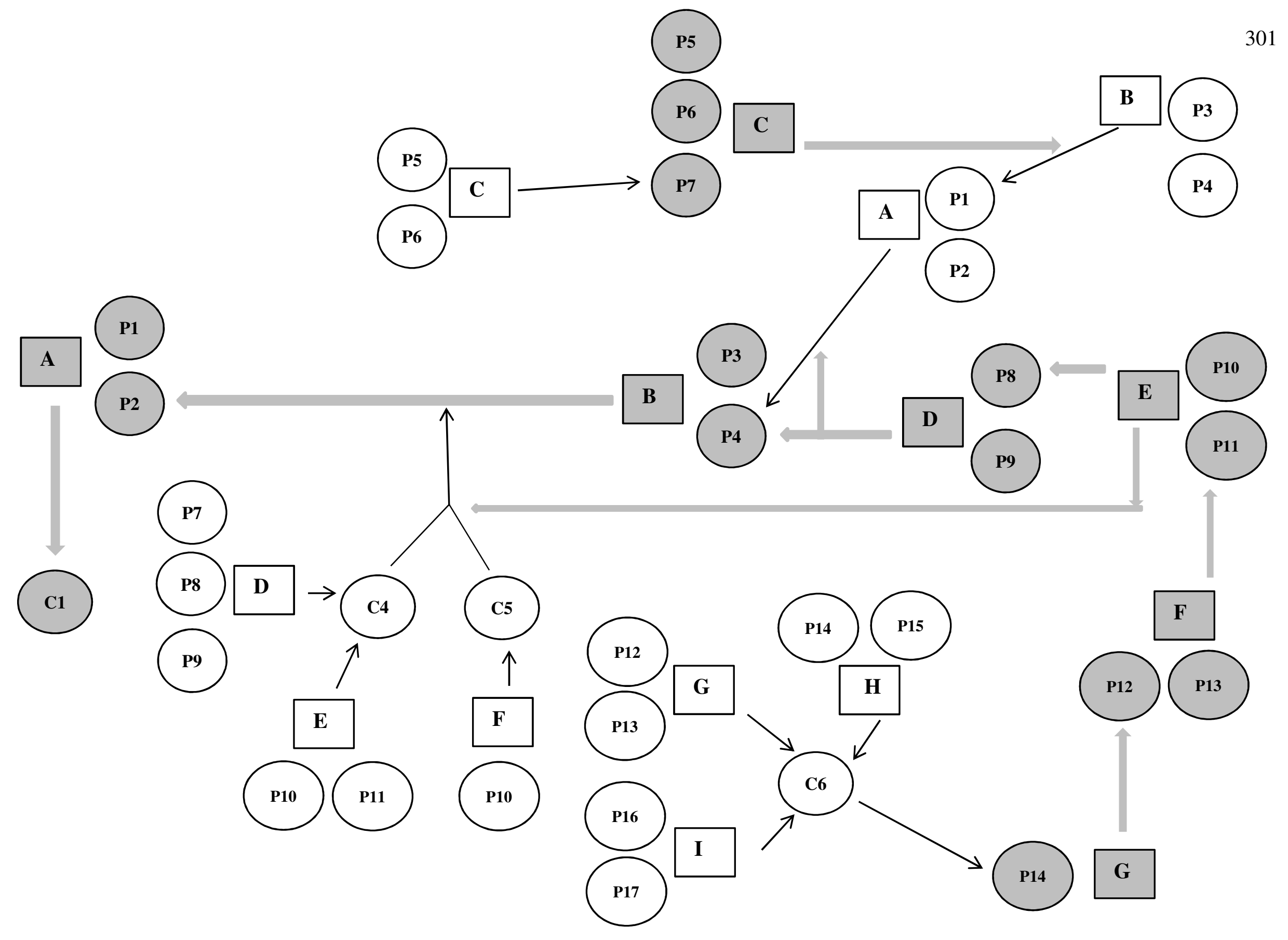




\section{Ausência de Comunhão de Propósitos}

\section{$\underline{\text { Contra Militares }}$}

Argumento A (Ausência de Conexão)

P1 A Lei de Anistia utilizou o conceito de conexão penal material (ou concurso material) previsto no Art. 69 do CP.

$P 2$ Os crimes dos militares não possuem conexão material com os crimes cometidos pela oposição armada.

$C 1\left({ }^{*} P 2 P M\right)$ Os militares não praticaram crimes conexos.

Fonte: Petição Inicial ADPF 153

Esquema: Justificação - Aplicação de Norma Jurídica.

Nota: A norma subjacente à P1 pode ser formulada "Se há conexão penal material nos termos do Art. 69 do CP, há conexidade entre os crimes nos termos do Art. $1^{\circ}$, $\S 1^{\circ}$ da Lei de Anistia".

\section{Argumento B (Coerência do Ordenamento)}

P3 O ordenamento jurídico utiliza seus conceitos de maneira coerente.

$C 2(=P 1)$ A Lei de Anistia utilizou o conceito de conexão penal material (ou concurso material) previsto no Art. 69 do CP.

Fonte: Petição Inicial ADPF 153

Esquema: Justificação - Aplicação de Norma Jurídica

Nota: Aplicação de norma interpretativa (P3).

\section{Argumento C (Ausência de Comunhão de Propósitos)}

P4 A conexão material (Art. 69, CP) entre crimes pressupõe que sejam cometidos pela mesma pessoa ou grupo de pessoas e com comunhão de propósitos ou objetivos.

P5 Os militares não participavam dos grupos da oposição armada nem possuíam comunhão de propósitos com eles.

$C 3(=P 2)$ Os crimes dos militares não possuem conexão material com os crimes cometidos pela oposição armada.

Fonte: Petição Inicial ADPF 153

Esquema: Justificação - Aplicação de Norma Jurídica. 


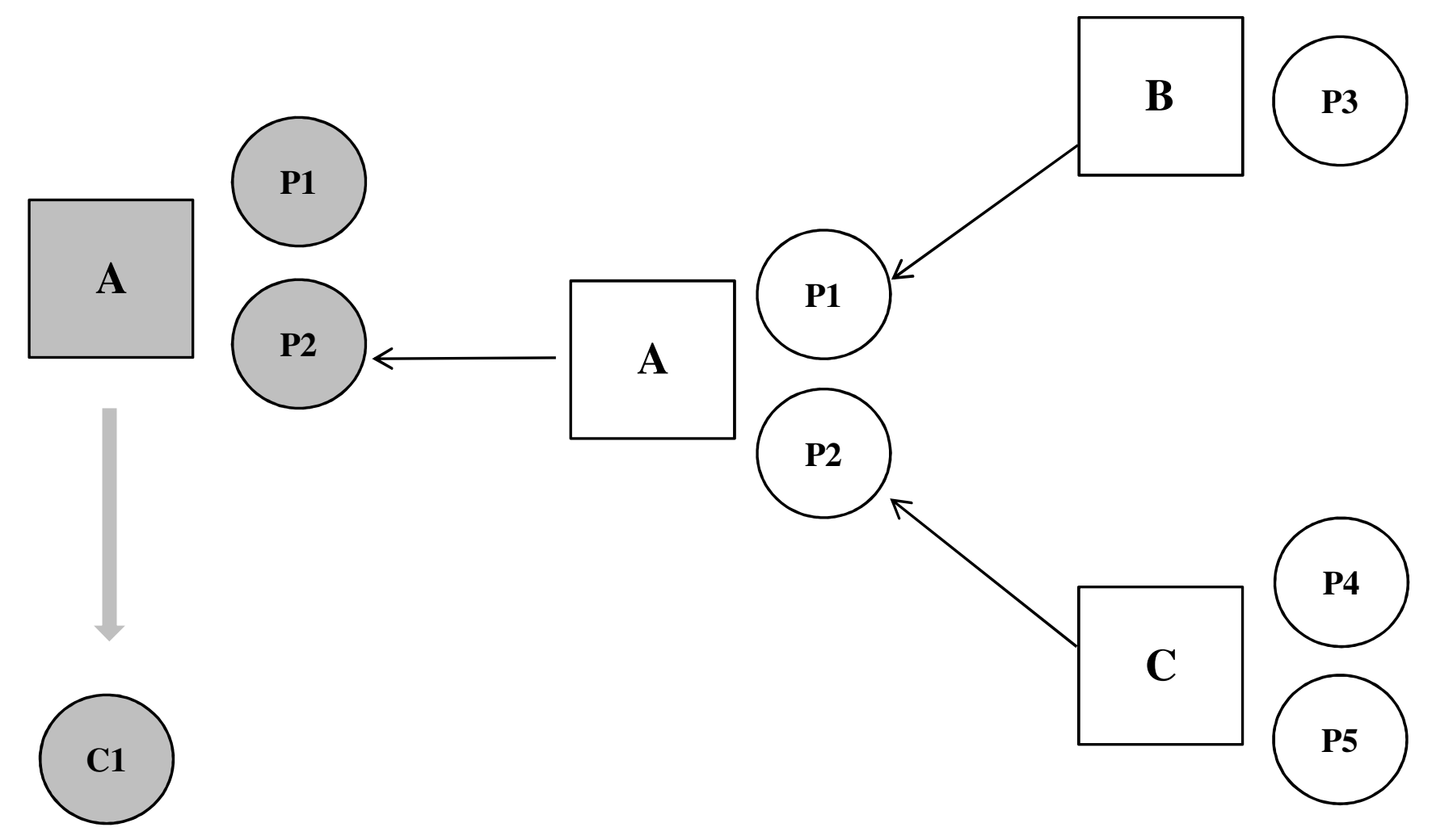




\section{$\underline{\text { Invalidade da Lei da Anistia }}$}

\section{Invalidade da Lei de Anistia - Jurisprudência da CIDH}

\section{$\underline{\text { Pró-Militares }}$}

Argumento B

P3 A jurisdição da CIDH só foi reconhecida em 8/11/2002, para fatos posteriores a 10/12/1998, conforme o Art. $1^{\circ}$ do Decreto ${ }^{\circ}$ 4.463/2002.

P4 A ditadura transcorreu de 1964 a 1985.

C2 A jurisdição da CIDH não se aplica aos fatos da ditadura.

Fonte: Swensson Jr. 2010, p.43-44

Esquema: Justificação - Aplicação de Norma Jurídica.

\section{Argumento C (Negociação Política)}

P5 Houve uma negociação política na qual se acordou que a anistia seria para a oposição e também para os militares.

$C 3\left({ }^{*} C M P 3\right)$ A Lei de Anistia dos militares no Brasil não promoveu uma autoanistia.

Fonte: APDF 153, Voto do Min. Eros Grau, p. 24-28.

Esquema: -

\section{Contra Militares}

Argumento A (CIDH e vedação da Auto Anistia)

P1 O Brasil aceitou a jurisdição da Corte Interamericana de Direitos Humanos.

$P 2$ A CIDH diz que as autoanistias são inválidas.

P3 A anistia dos militares no Brasil promove uma autoanistia.

C1 A Lei de Anistia é inválida no ponto da anistia dos militares.

Fonte: CIDH, Caso Gomes Lund, § 175.

Esquema: Justificação - Aplicação de Norma Jurídica.

Argumento B (Anistias de graves violações)

Pl O Brasil aceitou a jurisdição da Corte Interamericana de Direitos Humanos.

P4 A CIDH diz que são incompatíveis com a Convenção Interamericana de Direitos Humanos não apenas as autoanistias, mas também as anistias de graves violações de direitos humanos.

P5 No caso brasileiro houve graves violações de direitos humanos.

C1 A Lei de Anistia é inválida no ponto da anistia dos militares. 
Fonte: CIDH, Caso Gomes Lund, § 175.

Esquema: Justificação - Aplicação de Norma Jurídica.

Argumento C (Jurisdição para violações permanentes / André Ramos, Gomes Lund)

P6 No caso Blake vs. Guatemala, a CIDH afastou a restrição temporal para os casos de violação de caráter permanente.

P7 O caso Blake vs. Guatemala foi julgado (fundo) em 24/01/1998, antes do reconhecimento da jurisdição obrigatória da CIDH pelo Brasil.

P8 Quando o Brasil reconheceu a jurisdição da CIDH ele já tinha ciência da jurisprudência possibilitando a análise dos casos de violação de caráter permanente.

C2 A jurisdição da CIDH se aplica ao Brasil nos casos de violação de caráter permanente.

Fonte: RAMOS, 2004, p.309/310

Esquema: Justificação - Aplicação de Norma Jurídica.

\section{Comentários}

- Contra o argumento $\mathrm{C}(\mathrm{PM})$ poderiam ser opostos todos os argumentos apresentados acima contra a ideia de que ocorreu uma negociação política, no entanto, não será feita a repetição para não sobrecarregar o mapa.

- A consequência do argumento $\mathrm{C}(\mathrm{CM})$ é que a anistia dos militares não pode prosperar nos casos de violações de caráter permanente. No entanto, não atinge os casos de anistia por crimes que não sejam violações permanentes. 


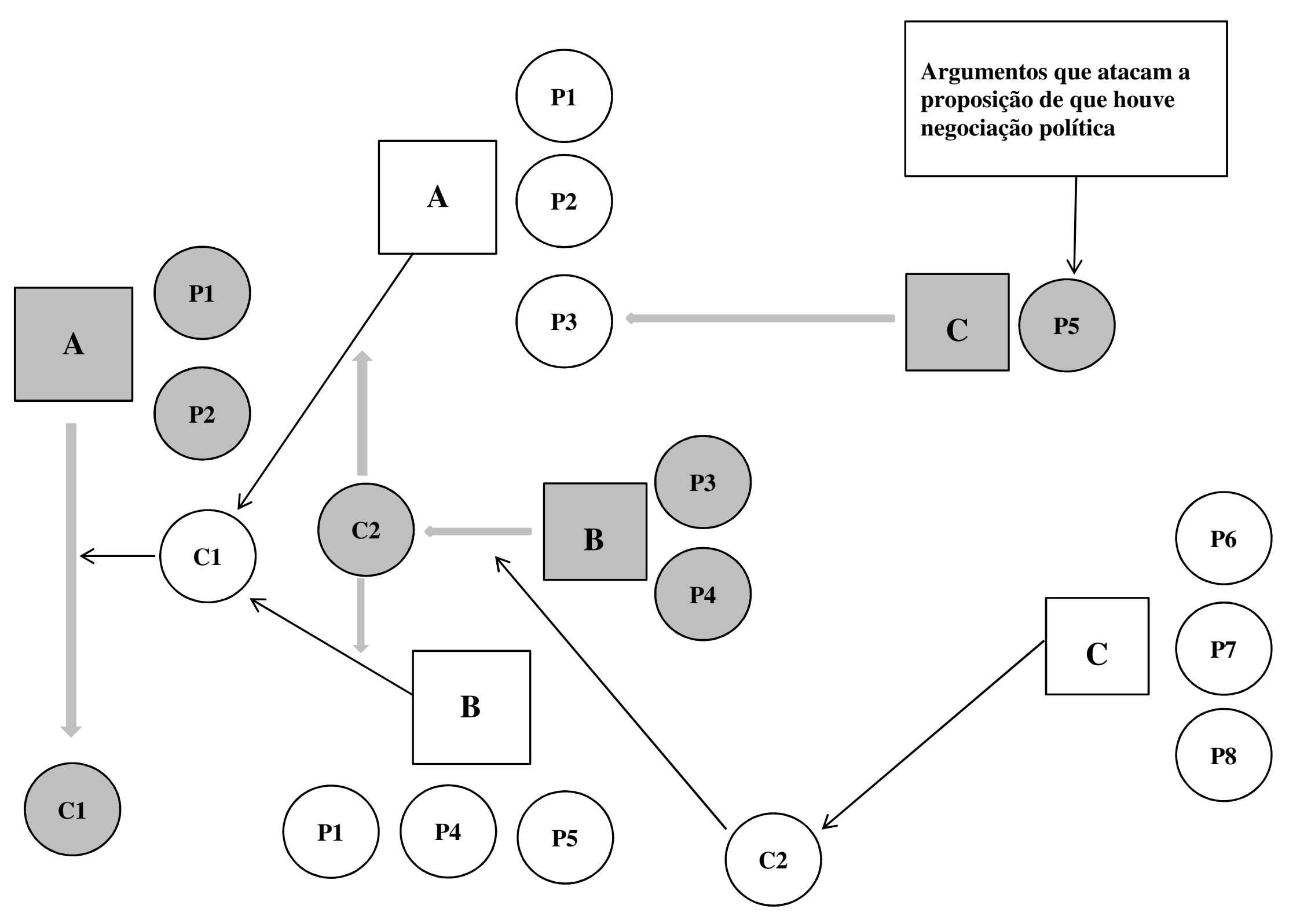




\section{Invalidade da Lei de Anistia - Crimes contra a humanidade}

\section{$\underline{\text { Pró-Militares }}$}

Argumento B (Necessidade de internalização)

P3 Para que as normas e institutos de direito internacional tenham força vinculante no ordenamento jurídico brasileiro eles devem antes passar por um processo de internalização. $P 4$ As normas referentes aos crimes contra a humanidade não haviam sido internalizados à época da Lei de Anistia.

C2 As normas de crimes contra a humanidade não podem ser aplicadas no caso concreto.

Fonte: -

Esquema: Operacionalização - Exceção.

Nota: Assumem-se as premissas P3 e P4 como verdadeiras por serem baseadas em normas e nos fatos.

\section{Argumento C (Não há lei escrita em sentido estrito)}

P5 O Art. $5^{\circ}$, XXXIX da CF/88 exige lei escrita em sentido estrito para se estabelecer um crime.

P6 Não há lei escrita em sentido estrito tratando dos crimes contra a humanidade.

$C 2$ As normas de crimes contra a humanidade não podem ser aplicadas no caso concreto.

Fonte: SWENSSON JR., p.42/43; ADPF 153, p. 190/194, Voto Min. Celso de Mello

Esquema: Justificação - Aplicação de norma jurídica.

Argumento D (Arbitrariedade e Insegurança)

P7 Seria arbitrário e inseguro para os acusados definir um crime por critérios diferentes que a lei escrita para os casos de supostas violações de direitos humanos.

Fonte: Analista

Esquema: Operacionalização - Exceção.

Argumento E (Ataque generalizado contra a população civil)

P8 De acordo com o Art. $7^{\circ}$ do Estatuto de Roma a existência de crimes contra a humanidade pressupõe o contexto de um ataque generalizado ou sistemático contra uma população civil.

P9 No caso concreto não houve ataque generalizado ou sistemático contra uma população civil.

$C 3\left({ }^{*} P 2 C M\right)$ Os crimes praticados pelos militares não foram crimes contra a humanidade.

Fonte: Analista

Esquema: Justificação - Aplicação de Norma Jurídica 


\section{Contra Militares}

Argumento A (Jus cogens e crimes contra a humanidade)

Pl O jus cogens de Direito Internacional diz que são inválidas as anistias de crimes contra a humanidade.

$P 2$ Os crimes de tortura, execução e desaparecimento forçado cometidos pelos militares foram crimes contra humanidade.

C1 A Lei de Anistia é inválida no ponto da anistia dos militares.

Fonte: -

Esquema: Justificação - Aplicação de Norma Jurídica.

Argumento B (Jus cogens dispensa internalização)

C2 O jus cogens não precisa ser internalizado para que seja aplicado por um Estado.

Fonte: -

Esquema: Operacionalização - Exceção.

Argumento C (Crimes contra a humanidade já foram internalizados)

P3 As normas e institutos que justificam as leis também se consideram internalizados.

P4 O Legislativo Brasileiro reconheceu os crimes contra a humanidade nas razões que ofereceu para a inclusão do Art. $1^{\circ}, \S 2^{\circ}$ da Lei de Anistia.

$C 3\left({ }^{*} P 4 P M\right)$ As normas referentes aos crimes contra a humanidade já havia sido internalizado à época da Lei de Anistia.

Fonte: Analista

Esquema: Justificação - Aplicação de Norma Jurídica.

Nota: Aplicação de norma interpretativa (P3).

Argumento D (Costume internacional é lei)

P5 O costume internacional satisfaz os requisitos de lei anterior do Art. $5^{\circ}$, XXXIX da $\mathrm{CF} / 88$.

$C 4\left({ }^{*} P 5 P M\right) \mathrm{O}$ Art. $5^{\circ}$, XXXIX da $\mathrm{CF} / 88$ não exige lei escrita em sentido estrito para se estabelecer um crime.

Fonte: Analista

Esquema: -

Argumento E (Objetivo do Art. $5^{\circ}$, XXXIX)

P6 O objetivo do Art. $5^{\circ}$, XXXIX da $\mathrm{CF} / 88$ é impedir a arbitrariedade e a opressão do Estado sobre os particulares. 
P7 Reconhecer apenas a lei escrita em sentido estrito como "lei" no presente caso é contrário ao objetivo da lei, pois a consequência seria justamente permitir a arbitrariedade e a opressão do Estado autoritário que agiria sem nenhuma forma de controle.

$C 4\left({ }^{*} P 5 P M\right) \mathrm{O}$ Art. $5^{\circ}, \mathrm{XXXIX}$ da $\mathrm{CF} / 88$ não exige lei escrita em sentido estrito para se estabelecer um crime.

Fonte: Analista

Esquema: Justificação - Objetivo da Lei.

Argumento F (Não há arbitrariedade ou insegurança)

P8 A previsão dos crimes contra humanidade está fundamentada no jus cogens e/ou na internalização pelas razões do Art. $1^{\circ}, \S 2^{\circ}$ da Lei de Anistia.

$C 5(* P 7 P M)$ Não há arbitrariedade ou insegurança em definir um crime por critérios diferentes que a lei escrita em casos de violações de direitos humanos.

Fonte: Analista

Esquema: - 


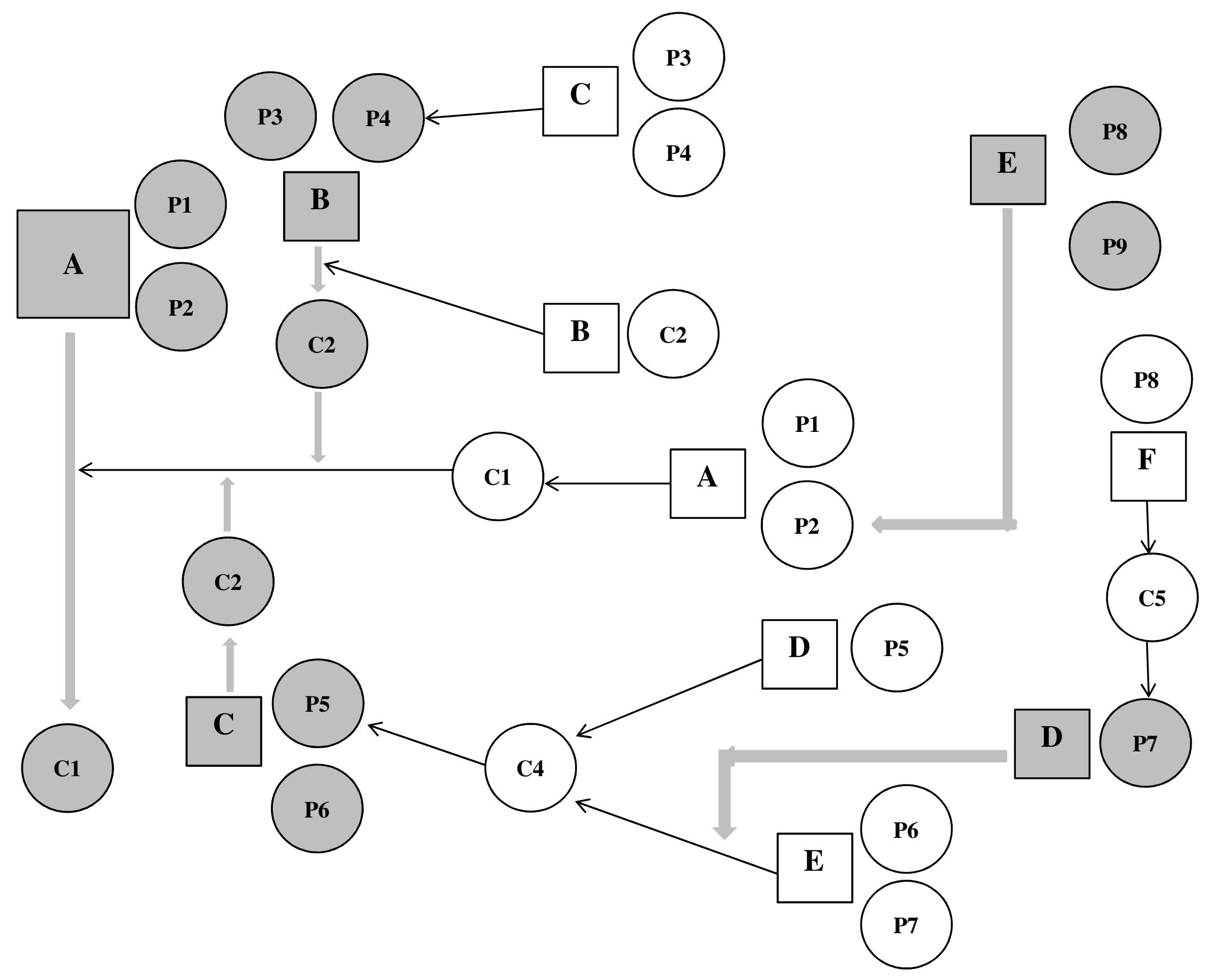




\section{I.1.A.2 Objeções Jurídicas Abstratas}

- Retroatividade: Há retroatividade penal caso os militares sejam punidos?

\section{$\underline{\text { Pró-Militares }}$}

Argumento B (Retroatividade encoberta)

P1 A lei penal não pode retroagir, salvo para beneficiar o réu.

$P 2$ A Lei de Anistia teve o efeito de descriminalizar os atos dos militares.

P3 Desfazer os efeitos da Lei de Anistia implicaria, de maneira encoberta, criminalizar os atos dos militares retroativamente.

C2 Não se pode desfazer os efeitos da Lei de Anistia.

Fonte: SWENSSON JR, p.40

Esquema: Justificação - Aplicação de Norma Jurídica.

Nota: Aplica-se o "princípio da irretroatividade penal". P2 e P3 compõe a premissa que diria "é o caso de retroatividade penal".

\section{Argumento C (Segurança jurídica e efeitos práticos)}

P4 O instituto da irretroatividade serve para proteger a segurança jurídica.

P5 A segurança jurídica protege tanto situações de direito (efeitos jurídicos válidos) como situações de fato (efeitos práticos, juridicamente inexistentes ou inválidos).

P6 A Lei de Anistia teve o efeito prático de não permitir que os militares fossem punidos.

C3 O instituto da irretroatividade protege os efeitos (práticos) da Lei de Anistia de não permitir que os militares fossem punidos.

Fonte: Analista

Esquema: Justificação - Objetivo da Lei.

\section{$\underline{\text { Contra Militares }}$}

Argumento A (Crimes Permanentes)

P1 Não há retroatividade no caso de crimes permanentes quando a continuidade do delito perdura após a edição de lei de anistia.

$P 2$ Os militares cometeram crimes permanentes, cuja continuidade perdurou até depois da Lei da Anistia.

C1 Anistiados ou não, os militares que cometeram crimes permanentes que perduraram até depois da Lei da Anistia podem ser perseguidos penalmente.

Fonte: Analista

Esquema: Justificação - Aplicação de Norma Jurídica.

Nota: P1 é a norma, baseada na interpretação de que se algo permanece não cabe falar em retroação. 
Argumento B (Correta interpretação da Lei de Anistia)

$P 3$ A intepretação correta da Lei de Anistia é a de que os militares não foram anistiados.

$C 2(* P 2 P M)$ A Lei de Anistia não teve o efeito jurídico de descriminalizar os atos dos militares.

Fonte: Analista

Esquema: -

Nota: Esse argumento depende do resultado da discussão sobre a intepretação correta da Lei de Anistia.

Argumento C (Invalidade da Lei de Anistia)

P4 Leis inválidas (nulas) não geram efeitos jurídicos.

P5 A Lei de Anistia é inválida (nula) no ponto da anistia dos militares.

$C 2\left({ }^{*} P 2 P M\right)$ A Lei de Anistia não teve o efeito jurídico de descriminalizar os atos dos militares.

Fonte: Analista

Esquema: Justificação - Aplicação de Norma Jurídica.

Nota: Esse argumento depende do resultado da discussão sobre a validade da Lei de Anistia.

Argumento D (Prescrição protege efeitos práticos)

P6 O instituto que serve para garantir a segurança jurídica das situações de fato (efeitos práticos, juridicamente inexistentes ou inválidos) é a prescrição e não a irretroatividade.

$C 3\left({ }^{*} C 3 P M\right) \mathrm{O}$ instituto da irretroatividade não protege os efeitos práticos da Lei de Anistia.

Fonte: Analista

Esquema: - 


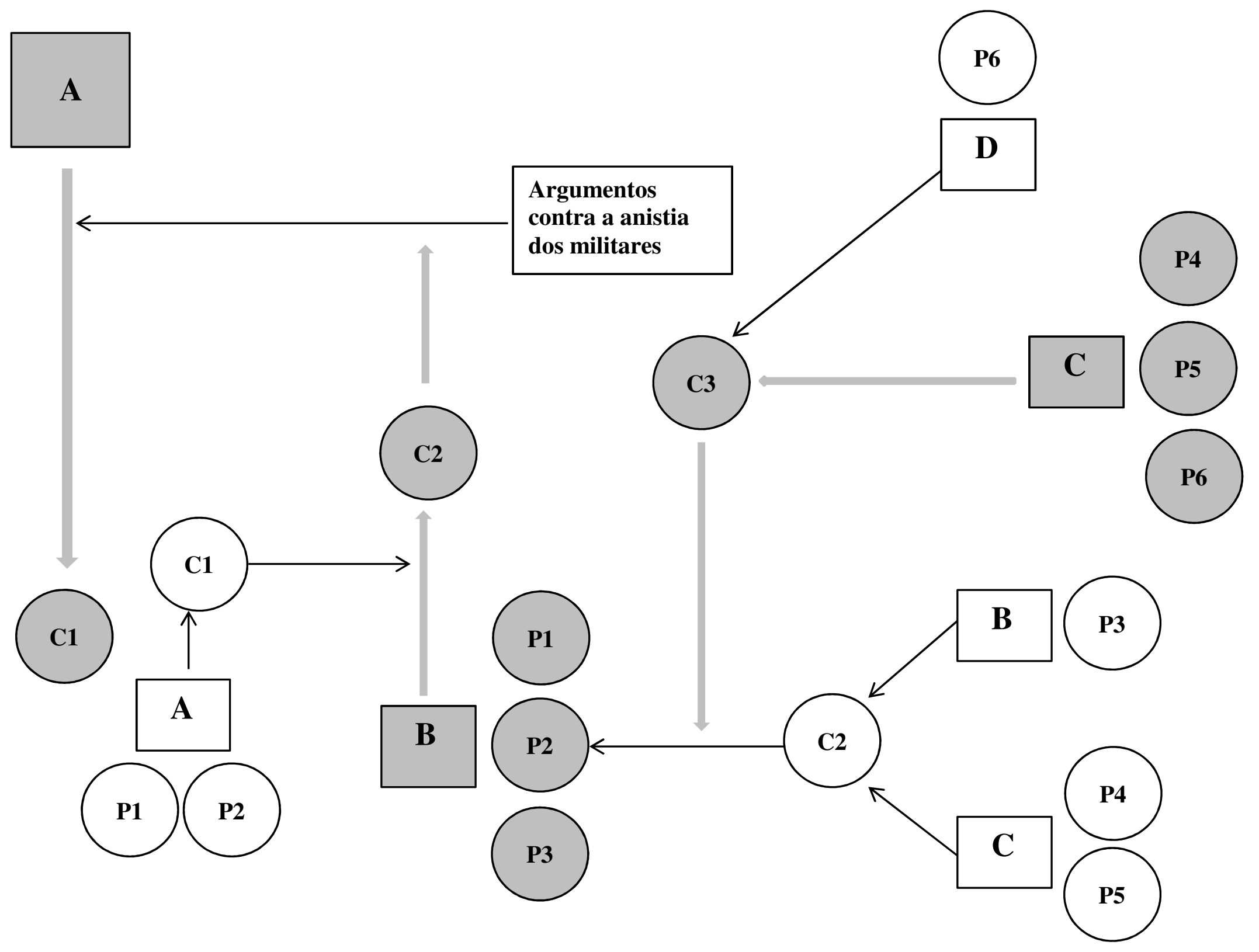

